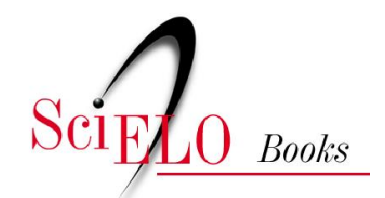

\title{
Argamassas tradicionais de cal
}

\author{
Cybèle Celestino Santiago
}

SciELO Books / SciELO Livros / SciELO Libros

SANTIAGO, CC. Argamassas tradicionais de cal. Salvador: EDUFBA, 2007. 202 p. ISBN 978-85-

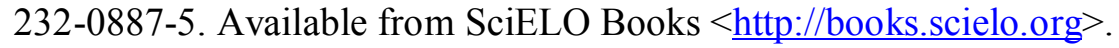

\section{(c) () $($ ()}

All the contents of this chapter, except where otherwise noted, is licensed under a Creative Commons Attribution-Non Commercial-ShareAlike 3.0 Unported.

Todo o conteúdo deste capítulo, exceto quando houver ressalva, é publicado sob a licença Creative Commons Atribuição - Uso Não Comercial - Partilha nos Mesmos Termos 3.0 Não adaptada.

Todo el contenido de este capítulo, excepto donde se indique lo contrario, está bajo licencia de la licencia Creative Commons Reconocimento-NoComercial-CompartirIgual 3.0 Unported. 
Argamassas
tradicionais de cal 


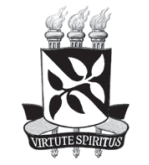

UNIVERSIDADE FEDERAL DA BAHIA

Reitor

Naomar Monteiro de Almeida Filho

Vice-Reitor

Francisco José Gomes Mesquita

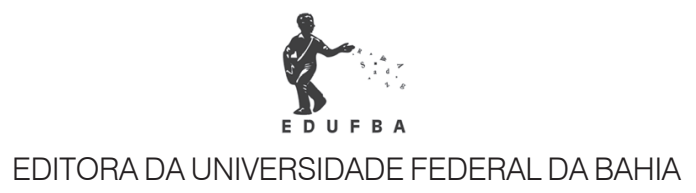

Diretora

Flávia Goullart Mota Garcia Rosa

\author{
Conselho Editorial \\ Titulares \\ Ângelo Szaniecki Perret Serpa \\ Caiuby Alves da Costa \\ Charbel Ninõ El-Hani \\ Dante Eustachio Lucchesi Ramacciotti \\ José Teixeira Cavalcante Filho \\ Maria do Carmo Soares Freitas \\ Suplentes \\ Alberto Brum Novaes \\ Antônio Fernando Guerreiro de Freitas \\ Armindo Jorge de Carvalho Bião \\ Evelina de Carvalho Sá Hoisel \\ Cleise Furtado Mendes \\ Maria Vidal de Negreiros Camargo
}


Cybèle Celestino Santiago

\section{Argamassas tradicionais de cal}

Salvador, Bahia - 2007 


\title{
(C)2007, by Cybèle Celestino Santiago \\ Direitos para esta edição cedidos à EDUFBA. \\ Feito o depósito legal.
}

\author{
Projeto Gráfico \\ Alana Gonçalves de Carvalho \\ Gabriela Nascimento \\ Editoração Eletrônica e Foto da Capa
Alana Gonçalves de Carvalho \\ Capa \\ Gabriela Nascimento \\ Revisão \\ Tânia de Aragão Bezerra \\ Magel Castilho de Carvalho
}

Biblioteca Central Reitor Macêdo Costa - UFBA

S235 Santiago, Cybèle Celestino.

Argamassas tradicionais de cal / Cybèle Celestino Santiago. -

Salvador : EDUFBA, 2007.

202 p. : il.

ISBN 978-85-232-0471-6

1. Arquitetura e história. 2. Argamassa. 3. Cal. 4. Agregados (Materiais de construção). 5. Areia. 6. Materiais de construção. I. Título.

CDU - 72(091)

CDD - 720.09

\section{EDUFBA}

Rua Barão de Jeremoabo, s/n Campus de Ondina, Salvador-BA

40170-290

Tel/fax: (71) 3283-6164

www.edufba.ufba.br edufba@ufba.br 
Para meu querido filho Matheus, que, sob enorme protesto, concedeu-me alguns dos nossos momentos de entretenimento e parceria para que eu pudesse revisar o texto. 


\section{Agradecimentos}

Adailton de Oliveira Gomes - pelas sugestões para a adequação do texto. Adriana Rodriguez Mayan - pelo auxílio na correção do texto e pela amizade e disponibilidade em ajudar, sempre que requisitada.

Allard Monteiro do Amaral - por sempre estar disponível como meu eterno consultor na área das argamassas.

José Baptista de Oliveira Júnior - pela pressão para que o texto fosse publicado e pela grande amizade, incentivo e idéias trocadas em diversos momentos.

Mário Mendonça de Oliveira - pelo apoio dado ao longo do desenvolvimento da pesquisa e por ter me incentivado a trilhar por estes caminhos.

Meus pais (Yára e Fernando), irmãos (Diana, Fernando e Gustavo), cunhado (Betto) - pelo apoio, assim como pelas sugestões dadas ao longo de todo o texto.

Virgolino Ferreira Jorge - pelas sugestões durante a elaboração do texto.

Amigos, obrigada! 


\section{Sumário}

\section{Introdução}

17 Argamassas

24 Caracterização

26 Argamassas com solo

31 Argamassas refratárias

32 Argamassas hidrófugas

36 Outras argamassas especiais

42 Traços recomendados

65 Cal

67 Noções genéricas

69 Matérias-primas tradicionalmente usadas

69 Rochas calcárias

75 Calcários marinhos

79 Calcinação

84 Extinção (hidratação)

93 Variação de massa e volume

96 Caracterização das matérias-primas e das cais

97 Índice de hidraulicidade

109 Areia

113 Formação das areias

120 Caracterização

129 Cuidados de utilização 
139 Outros constituintes das argamassas

142 Pozolanas italianas

152 Pó cerâmico

157 Terraços fluviais do Baixo Reno

158 Cinzas de Tournai

167 Considerações finais

175 Referências

177 Fontes manuscritas

177 Fontes impressas

189 Anexos

191 - llustrações

1982 - Transcrição da tabela dos ensaios realizados pelo engenheiro Ernesto Cunha (séc. XIX) com argamassas e cais de marisco (Brasil)

1993 - Caracterização de algumas matérias-primas usadas tradicionalmente na fabricação de cais

2004 - Caracterização de cais preparadas em laboratório com matérias-primas tradicionalmente usadas na construção civil no Brasil, até o século XIX 


\section{Introdução}

Desde que o homem deixou de habitar as cavernas, passou a utilizar os recursos que a natureza the oferecia, conforme as suas necessidades, na construção de moradias que pudessem abrigá-lo. Inicialmente, os recursos naturais eram apropriados da forma como se encontravam, e posteriormente foram por ele transformados, para aprimoramento de suas qualidades.

Os grupos humanos, inicialmente nômades, vagavam de território em território, a depender da disponibilidade de caça, frutas e materiais dos quais pudessem se valer, no cotidiano, para a sua sobrevivência. A oferta de matéria-prima e os rigores do clima, aliados ao potencial inventivo de cada um desses grupos, propiciavam diversidade de utilização dos recursos disponíveis, diferenciando uma comunidade da outra.

À medida que um indivíduo de um grupo comunicava-se com o de outro, ou à proporção em que seu conhecimento ia sendo enriquecido, através da troca de experiências, maiores cuidados eram tomados com a escolha dos materiais para a construção das suas habitações. A prática de vida então adquirida ia sendo transmitida às gerações futuras que, por sua vez, aperfeiçoavam o que haviam aprendido de seus antepassados em processo oral então vigente de transmissão do conhecimento.

Com o desenvolvimento da escrita, o seu saber passou, então, a ser registrado em documentos de diversas espécies e em vários tipos de suporte, o que colaborava para uma difusão de tecnologia maior entre os habitantes do nosso planeta e contribuía para melhorar a condição das suas fábricas, no que diz respeito ao conforto e à durabilidade. Cabanas de madeira, palha e cascas de árvores; habitações escavadas em solos de boa coesão; construções em tijolos de terra crua, em materiais cerâmicos, em alvenaria de "pedra e cal", são alguns dos exemplos de formas encontradas pelo homem para se proteger das intempéries ao longo do tempo. Todavia, apesar da evolução da ciência da construção, ainda hoje, em países menos desenvolvidos, é possível encontrar-se formas de habitação muito primitivas, semelhantes às que se faziam há milhares de anos, enquanto que, em outros, já se constrói com materiais avançados, ou materiais tradicionais trabalhados ou elaborados com o concurso de tecnologias cada vez mais desenvolvidas. 
Nos últimos cinqüenta anos, grande tem sido a ênfase dada ao estudo de materiais de construção, assim como também àqueles destinados especificamente à conservação e ao restauro, visto que o homem tem se preocupado com a maior durabilidade da sua obra, dedicando mais atenção à preservação do legado dos seus antepassados, o que vale dizer, à sua memória.

Mais recentemente, a preocupação com a "qualidade total" dos produtos, em geral, incluindo-se os diversos materiais de construção, já pode ser notada nas grandes metrópoles, contribuindo, sobremodo, para a melhoria dos bens que são colocados à disposição dos consumidores e, como contraponto, as legislações tornaram-se mais rigorosas neste sentido. Entretanto, muitos dos procedimentos relativos ao uso dos materiais de construção, empregados desde os primórdios da nossa civilização, têm sido menosprezados pelo homem atual. Isto fica patente ao verificar-se que os cuidados dispensados ao seu preparo e/ou à sua utilização são por vezes menores do que há duzentos ou trezentos anos atrás, muitas vezes por desconhecimento das experiências dos antigos, o que prejudica a qualidade da fábrica, a longevidade da obra e, no caso da conservação e da restauração, o bom resultado da intervenção.

Várias referências podem ser encontradas em antigos textos e documentos de arquivos sobre a qualidade, a forma de emprego, a durabilidade e os cuidados que deveriam ser tomados com os materiais de construção, em épocas passadas. Estas referências servem como subsídios importantes para o conhecimento que se deve ter hoje sobre o assunto, fundamental aos trabalhos de conservação e restauração, quando se faz necessário o reforço ou a reintegração de antigas estruturas no mister da conservação da memória e à construção moderna.

Para a elaboração deste livro, foram analisados textos italianos, franceses, portugueses e espanhóis, escritos entre o século I a.C. e o século XVIII e textos brasileiros escritos entre os séculos XVI e XVIII, com ênfase nos últimos duzentos anos ${ }^{1}$.

O ponto de partida para o estudo foi o tratado de Vitrúvio² ${ }^{2}$, escrito no século I a.C. É, entretanto, consenso, entre os autores de textos de arquitetura e engenharia analisados, que ao bom arquiteto compete 0 domínio de várias ciências, de modo que possa, com sucesso, ter condições de especificar corretamente os materiais de construção, assim 
como controlar todas as atividades ligadas à execução do projeto arquitetônico e da obra. Isto torna-se crucial quando se trata de um arquiteto que se dedica à conservação e à restauração. No entanto, ainda hoje, nem sempre tal conhecimento é familiar aos profissionais da área, pelo simples fato da pouca ênfase que se dá à importância do seu estudo.

Embora Vitrúvio já considerasse importante o conhecimento, por parte do arquiteto, das propriedades dos materiais de construção com os quais iria trabalhar, de modo que não fossem cometidos erros e se pudessem prover dos materiais adequados a suas construções ${ }^{3}$, os profissionais de hoje, por vezes, não se preocupam com o estudo das características daqueles materiais. Nem tampouco observam o que acontece com os mesmos ao longo do tempo, quando aplicados em determinadas situações, o que os ajudaria a evitar eventualmente em incorrer em erros banais, mesmo sem o conhecimento aprofundado das suas propriedades ${ }^{4}$. $\mathrm{Na}$ realidade, o que ocorre é que muitos estudantes e profissionais de arquitetura da atualidade passaram, como foi dito, a desprezar o caráter científico desta arte, esquecendo-se que o conhecimento da ciência dos materiais é fundamental à boa execução da obra arquitetônica. Se a nobre arte é utilitas e venustas, é primeiramente firmitas ${ }^{5}$. Além do mais, por vezes a beleza da construção está diretamente ligada à qualidade dos materiais ${ }^{6}$.

Este texto procura investigar, sob a óptica da ciência contemporânea, o que se pensava das argamassas de cal e alguns dos seus constituintes ao longo dos séculos, começando a partir da opinião de Vitrúvio, averiguando o que havia de verdadeiro em seus pensamentos, pelo que se acredita hoje em dia, constatando eventualmente informações corretas contidas nos documentos estudados que foram negligenciadas pelos profissionais contemporâneos. É fruto de uma pesquisa mais ampla sobre os materiais de construção, que culminou com a tese de doutorado intitulada "Estudo dos Materiais de Construção de Vitrúvio até ao século XVIII: uma visão crítica interpretativa à luz da ciência contemporânea", defendida na Universidade de Évora (Portugal) ${ }^{7}$.

Além de textos de arquitetura e engenharia, para a elaboração da tese foi necessário consultar outros sobre temas diversos - história natural, agricultura, matemática, física, química, hidráulica, história das ciências e, até mesmo, alquimia ${ }^{8}$-, por causa da natureza dos materiais de construção estudados. Enveredou-se, por esta razão, por outros campos 
da ciência, consultando inclusive especialistas diversos, como geólogos, físicos, químicos, engenheiros civis e de minas, arquitetos restauradores, dentre outros.

Entretanto, os textos importantes na época em que foram escritos e que, nos dias atuais, são fontes riquíssimas para a pesquisa e reflexão sobre os materiais de construção, são realmente os tratados de arquitetura e de engenharia militar. Abordam, dentre outros assuntos, tópicos como a escolha do terreno, o partido arquitetônico, as fases da obra, os materiais para a sua execução.

Os grandes nomes da tratadística nas áreas de arquitetura e engenharia, que viveram até o século XVIII e falaram sobre os materiais de construção ${ }^{9}$, basearam-se em Vitrúvio, apesar deste autor ser, por vezes, pelo que se pode depreender dos textos analisados, motivo de controvérsias. Contudo, mesmo quando seu nome não foi explicitamente citado, pôde-se perceber que os conceitos que emitiu permaneceram, até mesmo, em alguns textos que não se constituíram em tratados. O que eventualmente ocorria é que nem todas as idéias vitruvianas eram aceitas, simultaneamente, por um autor, o que poderá ser constatado oportunamente.

A idéia não é que este texto sirva como um manual para intervenções, mas que através dele seja possível conhecer melhor um material básico a argamassa de cal - presente na maioria dos nossos monumentos anteriores ao século XX.

\section{Notas}

${ }^{1}$ Ou publicações atuais, mas que consistem em reedições ou novas traduções de textos antigos, nestes idiomas ou em inglês.

${ }^{2}$ Marcus Lucius Vitruvius Pollio, arquiteto romano ativo no século I a.C. (46-30 a.C.), autor do mais antigo tratado de arquitetura que chegou aos dias atuais: De architectura libri decem

${ }^{3}$ VITRUVIO PÓLIO, Marco Lucio. Los diez libros de arquitectura, tradução, prólogo e notas de Agustín Blánquez, Barcelona, Ibéria, 1955. L. II, Cap. III, p. 40 - [...] para que, cuando estas propiedades sean conocidas por los que quieren edificar, no cometan errores y puedan proveerse de los materiales aptos y apropiados para sus construcciones // [...] para que, quando estas propriedades forem conhecidas pelos que querem edificar, não cometam erros e possam prover-se dos materiais aptos a apropriados para suas construções.

${ }^{4} \mathrm{O}$ uso, em zonas expostas às intempéries, de rochas de alto custo que se degradam com relativa facilidade é um exemplo claro disto, bastante freqüente nas obras atuais.

${ }^{5}$ Se a nobre arte é útil e bela, é primeiramente sólida. 
${ }^{6}$ Se um material estiver impregnado por sais, por exemplo, não apresentará boa qualidade, e ficará com um aspecto não muito agradável quando as eflorescências aparecerem na sua superfície, manchando-a (sem contar com a eventual escamação).

${ }^{7}$ SANTIAGO, Cybèle Celestino. Estudo dos Materiais de Construção de Vitrúvio até ao século XVIII: uma visão crítica interpretativa à luz da ciência contemporânea. Universidade de Évora (Portugal), 2001. 414p. Tese de doutorado.

${ }^{8}$ Porque, para Vitrúvio, as propriedades das rochas e madeiras eram justificadas pela sua constituição com base nos quatro elementos - água, terra, fogo e ar.

${ }^{9}$ Alguns textos considerados como clássicos não se referem aos materiais de construção, ou apenas Ihes fazem uma rápida menção. 


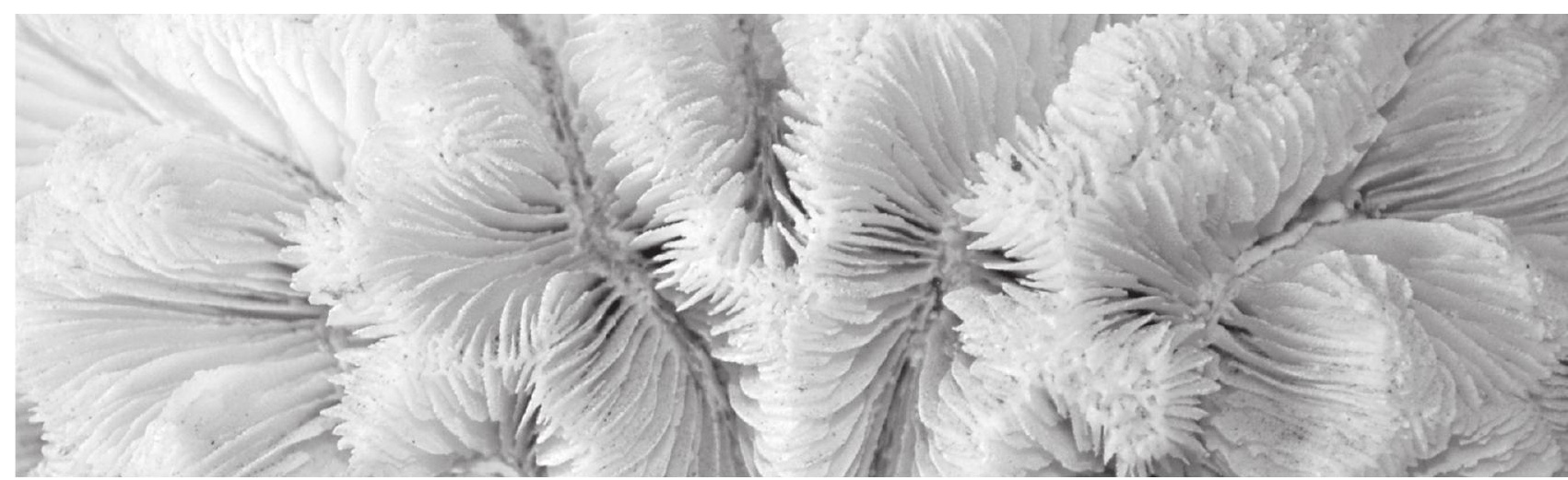

\section{Argamassas}


Ao tratar do tema das argamassas ${ }^{1}$, em uma tentativa de analisar o ponto de vista de antigos tratadistas e demais autores que escreveram sobre o assunto, a definição ora adotada não é a que, em dias atuais, é mais correntemente utilizada nos livros específicos sobre materiais de construção, ou nas obras. Isto porque tal definição é restritiva, incompleta, desde quando afirma que argamassa consiste em uma mistura de agregado miúdo, aglomerante e água, composição que nem sempre foi adotada ao longo do tempo. Por esta razão, neste texto serão tecidos comentários acerca de argamassas que apresentam composições diversas, e que não poderiam ser ignoradas somente pelo fato de não se encaixarem na definição padrão corrente.

No texto do escritor e moralista português, nascido em São Paulo, Mathias Ayres Ramos da Sylva de Eça (1705-1763), era recriminado o uso de qualquer material diferente de areia e cal nas argamassas ${ }^{2}$. Nem é necessário mencionar a radicalidade desta afirmação, que entra em contradição com muitas das opiniões da época, haja visto que nem sempre as argamassas eram assim constituídas: pelo contrário, segundo consta da bibliografia consultada, era bastante freqüente o emprego de outros ingredientes, como, por exemplo, pozolana, material cerâmico pulverizado, limalha de ferro, óleo, cinzas de Tournai. Em estudos realizados em finais do século XIX, o português J. da P. Castanheira das Neves indicou que, além de argamassas simplesmente feitas com cal e areia, entravam outros componentes nas misturas, tais como borra de ferro, pó de tijolo, massapez ${ }^{3}$, cinza de carvão ${ }^{4}$. 
Verificou-se, por exemplo, que Bernard Forest de Belidor (1697 ou 1698-1761), engenheiro militar catalão, no seu Dictionnaire portatif de l'ingénieur, concordou com arquiteto e historiógrafo francês André Félibien des Avaux $^{5}$ (1619-1695), pois a definição de argamassa dada por ambos foi a mesma:

Argamassa. É um composto de cal e areia, ou de cal e pó de material cerâmico, para unir as pedras. Dizemos que a argamassa é gorda quando tem muita cal ${ }^{6}$.

Tal definição é restritiva, pois através dela percebe-se que apenas o material composto por areia, cal ou material cerâmico pulverizado, e unicamente com a função de unir pedras, era considerado como argamassa. É mais completa, no entanto, do que a de Mathias Ayres.

Já que Félibien e Belidor especificaram que as argamassas serviam apenas para ligar pedras, que denominação receberia, então, o material usado para ligar tijolos e adobes? E que dizer da inclusão de pozolana ou gesso, ao invés de cal, citados com freqüência por outros autores? E do uso de terraços fluviais do Baixo Reno, sugerido pelo próprio Belidor, no mesmo livro??

Encontrou-se, ainda, em um dicionário técnico de finais do século XIX, a seguinte informação acerca das argamassas:

[...] quando são ordinárias, preparam-se com a cal grossa, misturandoIhe mais ou menos areia. Chama-se 'argamassa' gorda quando a cal é em muito mais quantidade do que a areia, e 'argamassa' magra quando a cal não é sufficiente para bem ligar ${ }^{8}$.

Notou-se que, para Francisco de Assis Rodrigues, autor do referido dicionário, as argamassas mais comuns eram misturas unicamente de cal e areia. Porém pelo menos foi deixada uma possibilidade de inclusão de outros tipos de ingredientes, apesar de não dar nem uma idéia de qual poderia ser a sua composição.

Embora os autores supramencionados tenham indicado apenas argamassas simples, compostas com uma base de cal e areia, em proporções variáveis, sabe-se que:

- Os babilônios usavam argamassas feitas da mistura de betume e barro ${ }^{9}$; 
- Paredes de adobes requerem argamassas feitas do mesmo material que os originou, em geral solo e água (às vezes, com adição de outros ingredientes, como palha ou cinzas) $)^{10}$;

- Hoje, são freqüentes as argamassas poliméricas (resina e pó de pedra, por exemplo), para a obturação de lacunas e fixação de camadas de reboco ${ }^{11}$.

Curiosamente, Antoine de Ville (1596-1656), engenheiro militar francês de renome, mencionou até mesmo o uso da própria água, sozinha, com a função de argamassa, no caso específico de uma cidade árabe:

As muralhas de Charra, cidade da Arábia, eram ainda mais maravilhosas, pois elas eram todas maciças em pedra de sal, e não tinham outra argamassa além da água pura para as unir ${ }^{12}$.

Na atualidade, a argamassa é genericamente considerada como uma pedra artificial, pelo fato de, após endurecer, apresentar características de certo modo similares às rochas, assim como desempenhar algumas das suas funções. Entretanto, este é um conceito recente, visto que, pelo que se pôde notar nos textos analisados, somente os materiais cerâmicos eram considerados como pedras artificiais.

No texto atribuído a Michel de Fremin, ao ser mencionada a execução de paredes em pedra, foram dadas informações interessantes a respeito das argamassas de cal (ou gesso) e areia:

As pedras e os matacões tão logo são extraídos causam também alguns problemas nas construções; a cal ou o gesso que serve para ligar uns aos outros, não tendo sua ação que por efeito do seu calor, a partir do momento que ela se encontra atacada pela umidade ou pela frieza que há nestas pedras, é evidente que estes são dois inimigos que impedem a aderência da areia e dos sais que estão na areia e no gesso, e que por este empecilho, a cal perde todo o efeito de sua ação ${ }^{13}$.

Ficou visível, através desta leitura, que se desconhecia, na época, a constituição do gesso, da cal e da areia, assim como as reações de endurecimento da cal e do gesso, que são diferentes entre si. Fremin mencionava, ainda, que a cal era formada por sais "doces" e "untuosos". As provas disto, segundo dizia-se, eram o tempo requerido para a sua extinção, o barulho que a cal fazia enquanto este processo ocorria e a 
sua aderência ao instrumento utilizado para mexê-la. Não se tinha percebido, até então, que a carbonatação de uma argamassa de cal só ocorre em presença de umidade e gás carbônico, e que a razão para a perda da capacidade de aderência, por parte do aglomerante, não é a umidade intrínseca de uma pedra nem sua frieza. No caso de argamassas cujo aglomerante era o gesso, o que deveria ocorrer era a sua lixiviação, eventualmente, ao serem utilizadas em exteriores ou em locais sujeitos à capilaridade ascendente. A umidade ${ }^{14}$ poderia, eventualmente, reduzir a velocidade de endurecimento da argamassa, ou causar sua queda, caso agisse conjuntamente com sais solúveis.

Sabe-se hoje que a areia, de maneira geral, é um material formado por sílica $\left(\mathrm{SiO}_{2}\right)$. Logo, não é, nem contém obrigatoriamente sal. A presença deste último composto só é naturalmente constatada em areias de origem marinha, ou areias fluviais próximas da foz dos rios, pois se estas não forem lavadas, ficam impregnadas por diversos sais, principalmente 0 cloreto de sódio ${ }^{15}$. O gesso, que consiste em sulfato de cálcio, nas suas diversas versões ${ }^{16}$, é que é um sal. A cal, a depender da forma sob a qual seja usada, é um óxido (cal virgem, ou cal viva) ou um hidróxido (cal extinta).

A primeira referência encontrada, ao longo desta investigação, acerca do emprego de argamassas, consta do tratado de agricultura intitulado Rerum rusticarum, escrito pelo historiador e soldado romano Marco Terencio Varrão (116-27a.c.). A informação que tal autor nos legou diz respeito a argamassas hidrófugas, que eram utilizadas para a proteção do trigo contra a ação da umidade e contra roedores:

As paredes e o solo devem ser revestidos com uma camada de massa formada com mármore pulverizado, ou ao menos argila misturada com palha de trigo e bagaço de azeitonas prensadas ${ }^{17}$.

Possivelmente, a massa de mármore pulverizado à qual Varrão fez referência deveria conter ainda cal e água, o que não está explicitado no texto. Já a segunda mistura proposta - argila, palha de trigo e bagaço de azeitonas prensadas - consistia em uma argamassa à base de solo, sem cal, nem areia, e que deveria ter características hidrófugas por causa da presença dos ácidos graxos existentes nas azeitonas. O problema que este material provavelmente apresentava era a susceptibilidade ao ataque 
biológico pela presença de componentes orgânicos, tanto por causa da palha, quanto pelo bagaço das azeitonas. A palha, inclusive, tinha que ser bem envolvida pela pasta formada com o solo, para que não ficasse em contato com a superfície externa das paredes ou dos pisos, após aplicada, o que fatalmente iria acelerar o seu processo de degradação e, conseqüentemente, a degradação do revestimento em si.

Outra referência do século I a.C. consta do tratado de Vitrúvio. Apesar deste escritor ter dedicado o livro II de seu tratado aos vários materiais de construção comumente utilizados na sua época, as informações acerca das argamassas não foram agrupadas de modo a constituir-se em capítulo especial. Podem ser encontradas nos capítulos sobre areia, cal e pozolana ${ }^{18}$, e também dispersas pelo restante dos livros que compõem o texto, como poderá ser verificado mais adiante.

Muitas das informações dadas foram baseadas nos conhecimentos práticos da época, e como a ciência ainda não tinha se desenvolvido, algumas das explicações encontradas para determinados fatos apoiavamse em considerações filosófico-alquimísticas. Para explicar a capacidade das argamassas em endurecer e adquirir resistência, por exemplo, Vitrúvio teceu considerações acerca dos quatro elementos - água, terra, fogo e ar - presentes, em sua opinião, nas pedras calcárias usadas na fabricação da cal. Deles resultaria a capacidade da cal aderir à areia, secar-se e adquirir resistência.

Sintetizam-se agora as indicações dadas por Vitrúvio, no que diz respeito à constituição, finalidade e proporção entre os diversos ingredientes das argamassas:

- Usar mistura de cal, areia, pó de tijolo e britas, ao invés de lajes de pedra, para revestir pisos de cisternas, piscinas e outros depósitos de água ${ }^{19}$;

- Adotar os traços 1:3 (cal, areia de jazida) e 1:2 (cal, areia de rio ou mar) 20 - Chama-se a atenção para o fato que na tradução de Blánquez tem-se ladrillos, ou seja, tijolos, enquanto que, na de Barbaro, spezzature di testi ${ }^{21}$, o que nos induz a pensar em material cerâmico não proveniente unicamente de tijolos, conforme informação encontrada no texto de Francesco di Giorgio Martini (1439-1501 ou 1502)22. Helena Rua (século XX), ao traduzir a versão 
de Perrault, falou de telhas moídas e peneiradas ${ }^{23}$. Estas pequenas diferenças existentes nos diversos idiomas para os quais foi traduzido o texto são fontes de equívocos na sua interpretação;

- Usar argamassa de tijolo moído para revestir as paredes, até uma altura de cerca de um metro, ao invés do emprego, unicamente, de uma mistura cal e areia, no intuito de impedir a penetração da água ${ }^{24}$.

Ao mencionar a qualidade da areia a ser utilizada na confecção de argamassas, Vitrúvio recriminou a presença de qualquer porção de material argiloso, sugerindo que se fizesse o teste de colocação da areia em um lenço branco para verificar se, após a retirada do material, o tecido permanecia branco - indício de que a areia era boa -, ou ficava sujo, o que implicaria na sua rejeição automática ${ }^{25}$. Esta informação, assim como os traços indicados por Vitrúvio, permaneceram como referências básicas sobre argamassas de cal até o século XIX, conforme mencionado por Rondelet no seu texto L'Art de bâtir, o que foi informado pelo investigador suíço Vinicio Furlan (séc. XX) ${ }^{26}$.

\section{Caracterização}

A argamassa é um material muito importante em qualquer construção feita com pedras, tijolos ou blocos cerâmicos, pois tem a função de juntar as diversas unidades desses materiais entre si. A outra função básica das argamassas é o revestimento, de modo a propiciar uma maior proteção aos vários elementos construtivos. Conseqüentemente, uma boa argamassa tem grande parcela de colaboração na durabilidade das edificações.

São condições que devem ser atendidas por uma boa argamassa ${ }^{27}$ :

- Compacidade - Quanto mais compacta, mais densa e, em geral, mais resistente a argamassa;

- Impermeabilidade - Característica fundamental, pois uma argamassa impermeável impede a penetração da água, um dos mais danosos agentes de degradação, nos edifícios ${ }^{28}$;

- Aderência - Caso isto não ocorra, não haverá boa união entre as diversas unidades por ela coladas. No caso de um revestimento, poderá haver um descolamento, que favorecerá a degradação; 
- Constância de volume - Para que não existam problemas neste sentido, é necessário que o calcário ${ }^{29}$ seja submetido a um processo de queima total, e que o óxido sofra extinção completa, o que, sabese, nem sempre ocorria antigamente. A extinção incompleta do material pode levar a inchamentos e esfoliação da superfície da argamassa, após aplicação, se ocorrer absorção de água. No caso da argamassa com barro, tem-se também a retração e o inchamento dos argilominerais.

Dessas propriedades decorrem as seguintes qualidades:

- Resistência mecânica adequada;

- Durabilidade - As funções básicas das argamassas são a união entre os diversos elementos da alvenaria (assentamento) e a proteção da parede (revestimento). Se o material não tiver características adequadas, ou em certos casos, não for protegido da ação das intempéries por detalhes de projeto específicos (beirais, passeios, impermeabilização), terminará por se degradar e, em consequência disto, haverá desunião entre os elementos por ele ligados e destruição do próprio substrato sobre o qual está aplicado.

As características supracitadas dependem basicamente do tipo, da quantidade e da qualidade das matérias-primas utilizadas. Os materiais devem ser isentos de impurezas e apresentar os requisitos mínimos para atingir, satisfatoriamente, os fins aos quais se destinam. A dosagem deve ser adequada, de modo que os grãos do agregado fiquem completamente envolvidos pela pasta (requisito básico para se obter uma boa resistência).

No caso do emprego de cimento tipo Portland, a argamassa não deve conter muitos finos, pois isto dificulta tanto o envolvimento dos grãos pela pasta, quanto a dispersão regular e homogênea dos mesmos. Se isto ocorre, ela apresenta pouca resistência à gelividade, maior permeabilidade, escassa resistência mecânica e durabilidade. No caso do uso da cal, ao invés do cimento, ao proceder-se a combinação desse aglomerante com a argila, há provavelmente a formação de neossilicatos, que melhoram as características da argamassa.

A retração da argamassa é diretamente proporcional ao percentual de água e cal presentes na mistura e dos argilominerais do solo porventura utilizado. Além da quantidade de água influenciar na velocidade de 
carbonatação da argamassa, é com base neste fator que a esta é classificada quanto à consistência. Desta maneira, as argamassas podem ser secas, plásticas ou fluidas, a depender da necessidade da obra.

Como não se encontram, na literatura antiga, informações precisas a respeito da quantidade de água usada nas misturas, supõe-se que estas fossem preparadas à base do sentimento, da experiência. $\mathrm{Na}$ realidade, a quantidade de água usada nas argamassas de cal não é um ponto crucial na dosagem, como é no caso das argamassas de cimento, embora influa na sua retratilidade e na sua estrutura porosa.

As características das argamassas dependem da utilização para a qual as mesmas são preparadas: se para assentamento ou para revestimento, com suas variantes ${ }^{30}$. O que acontece é que, nos textos anteriores ao século XIX, nem sempre esta distinção foi claramente feita.

Augustin Charles d'Aviler ${ }^{31}$ (1653-1700), por exemplo, mencionou a importância da escolha de uma boa argamassa e indicou traços e composições recomendados, porém deu uma definição simplificada do material, e nem citou o uso da argamassa em revestimento ${ }^{32}$.

\section{Argamassas com solo}

O padre Ignácio da Piedade Vasconcellos repetiu a opinião de Vitrúvio a respeito da areia, inclusive que esta não devia conter elementos terrosos, porém logo a seguir informou o seguinte:

Também se usa, novamente, nesta cidade de Lisboa, acharem os pedreiros huma terra vermelha, que chamão saibro, a qual alguma area tem misturada, (ainda que muito pouca) e se vê pela experiencia, que faz boa liga com a cal; e levando deste saibro meya parte, e outra meya de área de mina, também faz bom misto, e conglotina bem, levando a sua conta da cal $[\ldots]^{33}$.

Ou seja, o autor admitia, por experiência, o uso de material que contivesse ao menos uma determinada porção de elementos terrosos, o que é raro na literatura, porém mais condizente com a realidade, do ponto de vista arqueológico. A indicação é curiosa, considerando-se que era praxe, entre os tratadistas, recriminar o uso de toda e qualquer areia associada a partículas de argila, exatamente por alegarem que a cal não se uniria bem ao material. Atente-se, entretanto, para o fato que, mesmo 
tendo escrito isso, o autor disse textualmente concordar com Vitrúvio quanto à inadequação do uso de areias que continham terra nas argamassas.

O interessante é que os autores que eram efetivamente arquitetos ou engenheiros sempre foram taxativos, como Vitrúvio, quanto à isenção de terra em mistura com a areia, conforme exemplificado no capítulo referente a areias.

A dúvida quanto à inclusão, ou não, de solo nas argamassas persiste até hoje, em certos países. Uma argamassa de cuja composição participa o solo é chamada, na Bahia, de argamassa "bastarda". Em Portugal, a terminologia argamassa "bastarda" indica, por sua vez, uma argamassa em que o cimento tipo Portland vem adicionado à cal ${ }^{34}$. Ao longo deste texto foi adotada, para argamassa "bastarda", a primeira das definições acima: argamassa com solo.

No livro La science des ingenieurs, Belidor citou como argamassa "bastarda" aquela composta por cal proveniente de pedras boas misturadas com outras de má qualidade. Além deste tipo de argamassa tinha-se, segundo o autor, a argamassa boa, feita com pedras boas e duras - que deveria ser utilizada em obras "de responsabilidade" -, e a argamassa branca, feita com pedras comuns - para uso em fundações e grandes maciços de alvenaria ${ }^{35}$.

No texto atribuído a Fremin, assim como naquele da autoria de Jacques-François Blondel (1705-1777), o uso do solo na mistura foi condenado. Isto porque, segundo o primeiro deles, com a presença de tal material as argamassas ficariam untuosas, e as pedras que se tencionasse unir com elas deslizariam umas nas outras, o que não ocorreria, na sua opinião, caso fosse utilizada uma areia, por sua maior aspereza ${ }^{36}$. Já o último autor, apesar de não mencionar que as diversas unidades que compunham a alvenaria iriam deslizar, afirmou que a inclusão de terra na mistura não propiciaria a união entre elas ${ }^{37}$. O militar italiano Alessandro Vittorio d'Antoni Papacino, mas conhecido simplesmente como Antoni, concordou com J. F. Blondel, pois também era contra a inclusão de solo nas argamassas, alegando que o material perderia sua capacidade de aderência ${ }^{38}$.

A argila é realmente um material untuoso, tanto que esta característica é utilizada, ainda hoje, na sua identificação táctil, de maneira prática. No 
entanto, quando se mistura argila com areia, consegue-se uma certa estabilização do material, de modo que seria muito difícil que as pedras com ele assentadas viessem a deslizar. Lembra-se que, por vezes, o solo misturado apenas com água foi usado para unir pedras. Deste modo, muito provavelmente a afirmativa de Blondel não refletiria a realidade.

Alessandro Capra, arquiteto civil e militar italiano, indicou que, para se fazer uma boa argamassa, era necessário, segundo Vitrúvio e Andrea Paládio (1518-1580) ${ }^{39}$, que tanto a cal, quanto a areia, não contivessem $\operatorname{argila}^{40}$. Pela leitura destes dois últimos textos, assim como de muitos outros utilizados ao longo desta investigação, o que se notou foi a recomendação para que a areia fosse isenta de material terroso, porém nada explícito a respeito da cal também o ser. Talvez Capra tivesse assim deduzido pelo fato de ser sempre recomendada na sua confecção a pedra calcária a mais branca possível, já que aqueles calcários de coloração amarelada ou avermelhada normalmente contêm elementos argilosos. Porém isto não ficou claro no seu texto. Por outro lado, sabe-se que a argamassa cuja cal é feita com uma pedra que apresenta argila na sua constituição possui certa hidraulicidade, o que é interessante, em determinadas circunstâncias. Muitos foram os autores consultados que, mesmo sem ter esse conhecimento teórico, sugeriram a utilização de pedras como a pedra lioz ${ }^{41}$, e diziam que com ela poderia ser feita "a melhor cal do mundo" 42 .

Nos estudos de caracterização de argamassas de revestimento usadas tradicionalmente em Lisboa, efetuados em 1994 pelos investigadores portugueses José Manuel Nero e Júlio António Appleton e pelo brasileiro Abdias Gomes ${ }^{43}$, não foram encontrados elementos argilosos nas argamassas anteriores ao período Pombalino. Isto só ocorreu naquelas datadas do final do século XIX e do início do século XX, cujas análises indicaram um inerte avermelhado (saibro), assim como areia amarela.

Será que as argamassas "bastardas", ou seja, com solo, no Brasil, são assim feitas porque a areia de Portugal é, com freqüência, de cor marrom e parece conter solo, e como as pessoas no Brasil não arranjavam material semelhante passaram a acrescentar barro à mistura para ver se os resultados obtidos eram parecidos? 
Essa hipótese eventualmente poderia até ser válida no caso das construções brasileiras, mas acredita-se que a utilização do solo em argamassas tenha sido passada pelos mouros para a Península Ibérica, por ocasião de sua permanência naquela região, e dali para as colônias portuguesas e espanholas. O certo é que esta tradição não é comum em muitos países da Europa. Na Alemanha, por exemplo, essa prática é recriminada. Com relação a este aspecto, a equipe do Núcleo de Tecnologia da Preservação e da Restauração (NTPR), por ocasião do acompanhamento da visita de um arquiteto alemão ao Centro Histórico de Salvador, como parte de um projeto de cooperação internacional voltado para o estudo das argamassas antigas, recebeu a informação para não preparar corpos de provas de argamassas "bastardas", pois o citado arquiteto dizia que seu uso era recriminado pelo fato de ser um material que não propiciava aderência suficiente ao substrato, e descolava ou caía ao ser usado como revestimento de paredes. Na sua opinião, esta justificativa era reforçada pelos vários exemplos de paredes degradadas observadas naquela visita e, além do mais, o uso de solo em argamassas era condenado no seu país.

A equipe do NTPR teve que discordar do que o colega alemão dizia, por duas razões básicas:

- A tradição brasileira indica o uso de solo em argamassas de cal. Até mesmo nas argamassas contemporâneas que contém cimento tipo Portland, o solo é adicionado, sob a forma de arenoso (saibro) ou então caulim;

- As argamassas de revestimento observadas pelo próprio arquiteto alemão, que estavam praticamente íntegras, também eram feitas com os mesmos constituintes, ou seja, continham solo, e não haviam sido julgadas pelo mesmo como impróprias. As partes degradadas, normalmente, ficavam próximas das coberturas, e sua degradação decorria, principalmente, das infiltrações provenientes dos telhados, que carreavam o abundante aerossol salino ali depositado.

A argumentação que o material não servia por descolar e eventualmente cair é também utilizada por aqueles que dizem que as construções em terra não servem simplesmente porque muitas vezes 
podemos verificar que são realmente de terra, pois se tornam visíveis quando eventualmente há queda do revestimento. Só que, se este for bem elaborado, não deixará à mostra o material constituinte das paredes, de modo que não haverá queixas quanto à sua constituição.

Em outra investigação, efetuada pelos químicos portugueses Maria Olinda Reis e António Silva, concluiu-se, entretanto, que a argila foi realmente usada, ao longo dos séculos, como ingrediente eventual de algumas argamassas ${ }^{44}$.

Domaslowski (séc. XX) defendeu o uso de metacaolinita em argamassas de cal e cimento, para aumentar sua resistência mecânica e hidrorrepelência ${ }^{45}$. No Brasil, vários investigadores têm publicado textos sobre a adição de arenoso e caulim às argamassas que contém cimento, como pode ser comprovado nos anais dos Simpósios Brasileiros de Tecnologia das Argamassas que já foram realizados. É, pois, possível encontrar-se alguns textos nos quais o emprego de material argiloso é formalmente aceito, embora isto não ocorra com freqüência, especialmente quando se trata de uma argamassa cujo ligante é a cal.

Recentemente, no norte da Itália, foram descobertas várias construções executadas com argamassa "bastarda" 46 , o que é raro naquele país.

No NTPR foi desenvolvido um estudo à base da experimentação de diversas argamassas retiradas de monumentos antigos e de argamassas preparadas em laboratório, sendo constatado, no caso das argamassas de construção dos séculos XVII a XIX, misturas que continham, como componente básico, a ilita ou a caulinita ${ }^{47}$. Uma das conclusões desta investigação foi que, a depender do traço adotado, a adição de argila poderia aumentar a resistência à compressão das argamassas.

De acordo com Maria Isabel Luna e outros investigadores atuais, os seguintes tipos de argamassas foram tradicionalmente utilizados para revestimento de paredes feitas em terra: argamassa de argila, de cal, de gesso, de argila e cal, de gesso e cal, ou seja, por vezes o solo foi usado, apesar de seu emprego ter sido recriminado por vários autores ao longo de séculos ${ }^{48}$.

Sendo isto verdade, pode-se concluir que, possivelmente, a prática era, por vezes, diferente da teoria, ou que alguns autores simplesmente repetiam o que outros haviam dito, sem verificar se a informação era correta ou não. 
Uma hipótese que se levanta para explicar o fato é que, na época de Vitrúvio, o solo tivesse sido condenado nas misturas, mas que, posteriormente, tivesse sido uma prática romana o seu emprego, porém sem que tenha sobrevivido documento comprobatório do fato, de modo que os autores mais novos teriam simplesmente repetido em seus textos a indicação vitruviana, sem ao menos preocupar-se em verificar se o que era dito condizia com a realidade de então. Por exemplo, Michel Frizot, um pesquisador contemporâneo, afirmou que a argila, introduzida como impureza ou como constituinte, está realmente presente na maioria das argamassas antigas utilizadas, apesar de ser um material freqüentemente subestimado pelos autores ${ }^{49}$.

\section{Argamassas refratárias}

Praticamente não se encontrou, nos textos do período estudado, informações acerca de argamassas refratárias, ou seja, daquelas que resistiriam a altas temperaturas. Conhece-se, entretanto, tradicionalmente, no Brasil, a utilização do açúcar com esta finalidade, embora não se possa afirmar desde quando esta prática passou a vigorar.

Ao serem realizados, no NTPR, ensaios de resistência ao calor ${ }^{50} \mathrm{em}$ diversos tipos de argamassas com e sem solo, obtiveram-se os seguintes resultados: os corpos de provas elaborados com argamassa de cal e areia, e com argamassa de cal, areia e açúcar, foram decompostos; os de cal, areia e solo apresentaram rachaduras, e os de cal, areia, solo e açúcar nada sofreram ${ }^{51}$.

Atualmente, é comum, no Brasil, o uso de açúcar e solo em argamassas a serem usadas em churrasqueiras. Possivelmente porque 0 açúcar se decompõe por ação do calor, ficando em seu lugar poros que dão melhor estabilidade ao material, evitando problemas.

Apesar de referências ao solo como ingrediente presente nas argamassas, juntamente com a cal e a areia, serem raras, este material, no entanto, aparece ao longo da história com a função de unir pedras ou tijolos, tal qual uma argamassa, e por vezes com a função de resistir ao calor. Belidor, por exemplo, recomendou, para abóbadas de fornos de padaria, executadas em tijolos, o emprego da argamassa composta apenas por terra argilosa, fazendo uma ressalva para que não se usasse, 
com esta finalidade, a argamassa de cal e areia, porque ela poderia se decompor, com o calor, e cair em pouco tempo ${ }^{52}$. Este autor acreditava, pois, que a argamassa feita somente com solo (e água, obviamente) resistiria mais ao calor do que a que fosse feita apenas com cal e areia, o que realmente ocorre.

Na realidade, o hidróxido de cálcio ${ }^{53}$ existente na argamassa de cal, em presença de umidade e de gás carbônico, sofre processo de carbonatação, e transforma-se em carbonato de cálcio.

Citação curiosa, que fez referência exatamente a este fato, foi encontrada no tratado manuscrito do arquiteto português Mattheus do Couto $^{54}$ (finais do séc. XVI-Ca.1664), datado de 1631, é um dos exemplos:

Havemos de saber que todas as couzas tornão a seu principio, bom exemplo temos em nós q'tornamos a ser terra de que fomos principiados. Assi havemos de considerar, que a cal se faz de pedra, e tanto está nas paredes, que se ella hé bem caldeada torna a ser pedra ${ }^{55}$.

O carbonato de cálcio resultante do endurecimento da argamassa é o mesmo composto presente no calcário, a matéria-prima que, após calcinação e extinção, dá lugar à formação do óxido e do hidróxido de cálcio (a cal viva e a cal extinta, respectivamente), este último o aglomerante utilizado na fabricação da argamassa. Logo, pode-se afirmar que o círculo se fecha, quando há nova queima, seguida de hidratação.

No caso da utilização de terra argilosa, como sugeriu Belidor, quando o material era submetido às altas temperaturas do forno, não corria o risco de se decompor, visto que havia uma queima deste material, e o mesmo tornar-se-ia resistente ao calor, já que se ceramisaria.

\section{Argamassas hidrófugas}

Apesar de, atualmente, ter-se perdido o hábito da utilização de betumes naturais para impermeabilização de juntas de cantaria, em um texto publicado no início do século XX ainda era possível encontrar algumas receitas com este tipo de indicação, ao exemplo das citadas pelo engenheiro mecânico Carlos Ferreira:

'Betume para cantaria' - pó de pedra 1 parte, cal virgem 1 parte, ou pó de pedra 1,725 litros, cal virgem 1,725 litros, azeite, 1,5 litros[...]

'Betume para pedra e para marmore' cal viva pulverisada [sic] amassada com clara de vvo $^{56}$. 
Na realidade, diversas argamassas hidrófugas com composições tão peculiares quanto as acima citadas foram encontradas em alguns dos documentos pesquisados. Vitrúvio, por exemplo, sugeriu usar cal viva com azeite para proteger o piso da umidade ${ }^{57}$. Este mesmo autor recomendou, igualmente, o uso cal viva com óleo para vedar as juntas da tubulação dos aquedutos ${ }^{58}$, o que foi igualmente mencionado por Faventinus ${ }^{59}$. Ainda no texto vitruviano, foram encontradas referências ao uso de pasta de cal e pó de mármore ${ }^{60}$, material cerâmico pulverizado, e de uma argamassa hidráulica com traço 1:2 (cal, pozolana) ${ }^{61}$.

O romano Plínio62, o Antigo (23-79), por exemplo, que era médico e estudioso de história natural, indicou o uso do óleo misturado com cal viva, de modo que o produto resultante tivesse características hidrófugas:

É algo muito útil conduzir a água das fontes por tubos com dois dedos de diâmetro, que se encaixam um no outro em forma de bolsa, de modo que o superior entre, rebocados por cal viva com óleo ${ }^{63}$ (Grifo não existente no original).

O arquiteto e tratadista italiano Leon Battista Alberti (1404-1472) também fez referências a argamassas hidrófugas: falou em cal misturada com azeite (na fixação de telhas) ${ }^{64}$. Além disto, para a vedação de pequenas fissuras em pavimentos a céu aberto, sugeriu cinzas bem peneiradas misturadas com óleo (melhor se de linhaça), ou argila bem misturada com cal viva, cozida ao forno e logo a seguir igualmente misturada com óleo, depois da remoção do pó da fissura ${ }^{65}$.

Como, segundo a tradição oral, o óleo de baleia, óleo usado no Brasil Colonial em iluminação pública, pode ter sido eventualmente empregado no preparo de argamassas hidrófugas ${ }^{66}$, optou-se por tentar fazer uma experiência misturando cal viva com este óleo (além de misturála com azeite de oliva).

$\mathrm{Na}$ realidade, a maioria dos óleos se comportaria de maneira semelhante ao ser misturado com a cal viva, pois todos eles são formados por ácidos graxos.

Em alguns ensaios feitos em laboratório, no intuito de testar a capacidade da mistura da cal viva com azeite repelir a água, o óxido de cálcio foi retirado do forno mufla, colocado no dessecador (para resfriar sem absorver a umidade do ar) e posteriormente empastado com azeite, sendo mexido com o auxílio de uma espátula. Não houve aquecimento 
no recipiente que denotasse a ocorrência de reação exotérmica, nem qualquer alteração imediata que pudesse ser notada a olho nu. Os dois materiais, quando usados juntos, deveriam apenas formar uma espécie de pasta, que com o tempo iria secar e conferir certo grau de impermeabilização ao local onde fosse aplicada: no máximo, haveria a formação de um sal de cálcio, mas esse produto não teria propriedades dignas de menção. Optou-se, então, por deixar o material à temperatura ambiente por algum tempo, verificando-se que, com o passar dos dias, a mistura, que estava fluida, foi ficando mais pastosa.

Resolveu-se, também, tentar empastar a cal viva com óleo de baleia, de modo a verificar se haveria diferenças de comportamento entre os produtos. Os componentes dos óleos, em geral, são os mesmos: o que varia, basicamente, é o percentual presente dos diversos compostos orgânicos. Só que o óleo de linhaça é secativo, e o azeite de oliva e o óleo de baleia não o são. Constatou-se, imediatamente após a mistura, o aquecimento da mesma e a formação de pelotas, quando do uso do óleo de baleia.

Francesco di Giorgio Martini, ao fazer menção às argamassas usadas na construção de cisternas e na junção de tubos, também deu uma informação do emprego de óleo de linhaça ou, na sua falta, do azeite de oliva.

Em uma nova série de ensaios, misturou-se, então, óxido de cálcio com óleo de linhaça e óxido de cálcio com azeite. Verificou-se que, com o passar do tempo, as misturas de cal viva com óleo de linhaça e azeite aumentaram de volume antes de se converterem em pasta, mas não se constatou aumento algum de temperatura ao longo da experiência, como ocorreu no caso do uso do óleo de baleia.

Martini, curiosamente, forneceu alguns traços e ingredientes de possíveis misturas hidrófugas, indicando o modo de preparo da argamassa hidráulica:

Devem-se os ditos tubos ou manilhas deste modo serem conectados. Primeiramente, na sua junção, deverá ser usada esta composição: pegue-se óleo de linhaça e cal viva, misturados juntos, e com esta mistura vede a sua junção. E não podendo ter do óleo de linhaça, pegue-se do óleo comum. A este mesmo acrescente duas partes de cal viva, uma parte de cinzas de azinheiro, e tanto óleo para empastar quanto necessário. Igualmente pegue duas partes de cal, uma parte 
de cinzas de azinheiro, meia parte de vetriolo romano ${ }^{67}$, e tanto óleo quanto seja necessário para empastarb8.

Ou seja:

• 1,00:0,50 (cal viva, cinzas de azinheiro) + óleo em quantidade suficiente para empastar;

• 1,00:0,50:0,25 (cal viva, cinzas de azinheiro, sulfato de cobre) + óleo em quantidade suficiente para empastar.

As misturas são muito diferentes, porém o fato de conterem óleo, por si só, já é indicativo da sua hidrorrepelência.

Notou-se, pois, que era realmente de praxe, ao que parece, o uso da cal viva com óleo desde, pelo menos, a época de Vitrúvio, até o século XV. No Vocabulário técnico e crítico de arquitectura encontra-se, inclusive, uma informação sobre a adição de óleo em argamassa:

TETIM, s.m. argamassa feita de pó de tijolo, cal e azeite ${ }^{69}$.

Só que, infelizmente, não foi especificado onde, nem em que período, isto ocorria. Contudo, D. Clemente da Silva-Nigra informou que Francisco de Frias da Mesquita, engenheiro-mor do Brasil no primeiro quartel do século XVII, havia aplicado o tetim em uma abóbada, para minorar os problemas advindos da umidade ${ }^{70}$.

O brigadeiro português Manoel de Azevedo Fortes (1660-1749), ao mencionar uma argamassa impermeabilizante, sugeriu que fosse feita de cal, pó de telha peneirado e betume ${ }^{71}$. Não especificou, no entanto, mais detalhes. Talvez tenha omitido tais informações exatamente por acreditar não se poder atribuir uma composição padrão a uma determinada mistura, o que é correto. No entanto, atualmente, fica difícil de se fazer uma interpretação crítica da sua opinião, pois não há nem a indicação de qual o tipo de betume utilizado, já que era um termo genérico antigamente.

Com o caráter ilustrativo, cita-se um exemplo de argamassa impermeabilizante, denominada genericamente por betume, indicada pelo jesuíta austríaco Christiano Rieger para unir pedras de uma alvenaria irregular expostas ao ar ou à água:

O mais simples é de pó de tijolo e cal, e para unir peças de estátuas, ou uma pedra com outra, ou pedra com madeira, ou também madeira com madeira, é coisa muito boa e firme o 'coalhadão' que se faz de 
coalhada de leite e cal viva, a qual se misturará de modo que faça uma massa muito aquosa ${ }^{72}$.

Que tipo de reação deveria ocorrer ao se combinar coalhada com cal viva? Serão indicadas, no capítulo correspondente à cal, algumas peculiaridades das misturas de cal viva com óleos variados, constatandose que se processa uma reação química completamente diferente de quando se mistura os mesmos óleos com cal extinta.

Rieger indicou ainda que outros betumes, usados em reservatórios, eram feitos com diversos materiais, como pó de pedra, óleo de linhaça e estopa, e disse que na sua opinião a melhor composição era:

Um alqueire de pó de pedra de cantaria, oito alqueires de limalha de ferro, doze alqueires de cal viva, seis alqueires de farinha de toba ${ }^{73}$, quatro alqueires de farinha de vidro, oito alqueires de pó de tijolo e quatro onças de litargirio ${ }^{74}$; tudo isto moído e passado por uma peneira de crinas de cavalo, se amassará com 6 litros e 48ml de óleo de linhaça: depois se bate bem, até que fique uma massa bem macia, e se misturarão, e se baterão uns pelos de cabra silvestre ou de algodão ${ }^{75}$.

Pó de pedra, limalha de ferro, cal viva, pó de determinada pedra, pó de vidro, pó cerâmico, litargírio, óleo de linhaça, pêlo de cabra silvestre (ou algodão). Que mistura mais estranha e complexa! Não se sabe o comportamento da mesma, mas ao menos é imediata a constatação que ela apresenta alguns componentes tidos como hidrófobos. À primeira vista, o ingrediente distoante, por não ser hidrófobo, seria o último do rol: pêlo de cabra silvestre. E por que silvestre? Fica a questão.

\section{Outras argamassas especiais}

No texto de Plínio, além da mistura de óleo com cal viva, foram verificadas as seguintes indicações:

- Para argamassas de assentamento, de maneira geral, ao usar areia de jazida, "[...] se deve dar a quarta parte de cal. Mas àquela de rio, ou de mar, a terça parte; e se for acrescentada a terça parte de vasos moídos, será melhor"76 - Curiosamente, em uma das edições consultadas, que é bilingüe (latim/inglês), a indicação deste traço, em inglês, foi dada em massa ${ }^{77}$, o que não ocorreu nesta edição italiana. Sabe-se, inclusive, que isto não era comum em épocas 
passadas, quando os traços normalmente eram indicados em volume. Trata-se, como pode ser constatado pela leitura da passagem em latim ${ }^{78}$, de mais uma inadequação de tradução que pode semear a confusão quando se deseja fazer um aprofundamento técnico da fonte;

- Para argamassas de revestimento, Plínio recomendou uma parte e meia de cal e uma de pó de mármore;

- Fazer a argamassa com cal fresca, extinta em vinho, misturando-a logo em seguida com banha de porco e figos, o que lhe propiciaria dureza similar à da pedra ${ }^{79}$.

Como pode-se notar, são muito diferentes os tipos de argamassas indicados somente por este autor. Além disto, no seu texto podem ser encontradas formas de preparo do material que não foram citadas por outros autores, e que precisam ser testadas para que seja verificado se funcionam.

Encontrou-se, no texto de Alberti, a recomendação para que os revestimentos fossem sempre feitos em três camadas, de modo a se conseguir uma boa aderência da camada de acabamento, evitar o aparecimento de fissuras, e garantir o endurecimento da superfície exposta. Ainda segundo este autor, quanto maior fosse o número de camadas, mas perfeito seria o acabamento da superfície, e mais resistente ela seria, tendo, por esta razão, os antigos utilizado até nove camadas ${ }^{80}$.

Tal revestimento só poderia funcionar bem, sem descolar do substrato, caso fosse composto por camadas muito finas, pois camadas muito espessas tendem a ficar pesadas e destacam-se da parede. Além do mais, quando a superfície externa de um revestimento é carbonatada, impede o acesso do dióxido de carbono ao interior do revestimento, e este, caso tenha sido feito à base de cal, permanece em estado pastoso. Quando as camadas são espessas, pior ainda a situação.

Pela descrição do próprio Alberti, as primeiras camadas deveriam ser feitas com areia de jazida e pedaços de tijolos ${ }^{81}$; as camadas intermediárias, de areia de rio, pois este era um material mais resistente ao aparecimento de fissuras; e a última, de pó de pedra bem branca, com meia polegada de espessura, pois se fosse mais espessa demoraria a secar $^{82}$. Pela descrição não é possível afirmar se as primeiras camadas 
consistiam, de fato, em embrechamento ${ }^{83}$ ou encascamento, porém constata-se que a espessura do revestimento era por vezes demasiada, o que deveria acarretar problemas.

Por outro lado, em vez do uso da cal em uma argamassa para fixação de placas finas de mármore, Alberti sugeriu uma mistura aquecida de cera, breu, resina, mastique e qualquer variedade de borracha, aplicada após a segunda camada de reboco, recomendando que fosse feito, após aplicação, o aquecimento cuidadoso para não romper a pedra ${ }^{84}$. Um material de construção composto por ingredientes desta natureza equivale, hoje em dia, a uma cola, e não a uma argamassa.

Já na fixação das peças de um mosaico, a informação dada pelo mesmo autor foi que a cal devia ser misturada com pó fino de travertino. O curioso é que, na indicação desta última mistura, foi ainda proposto o seguinte:

Lavar bastante a cal com água fervente, para livrá-la do sal e torná-la mais macia e viscosa ${ }^{85}$.

Estaria a cal mencionada sob a camada de areia usada com freqüência na sua extinção, de modo que os sais presentes seriam da areia? Não parece. Entretanto, nada foi mencionado por Alberti com relação à remoção dos sais da areia, o que foi encontrado, pela primeira vez, no texto De re rustica, da autoria de Palladius Rutilius ${ }^{86}$, autor que provavelmente viveu no século IV.

Pela primeira vez, encontra-se a recomendação para que fossem eliminados os sais presentes na cal. Impossível, no entanto, ir além das conjecturas. Todavia, quer os sais estivessem presentes na cal ou na areia, a lavagem com água quente funcionaria para removê-los, pois facilitaria o processo de solubilização.

Os tratadistas portugueses do Setecentos, Mathias Ayres e Negreiros, não sugeriram a lavagem da cal. No entanto, tendo em vista que normalmente os calcários eram isentos de sais solúveis, recomendaram que não se procedesse a extinção com água salobra, ou do mar. Isto para que, ao longo de tal etapa de produção, os sais não fossem adicionados involuntariamente ao produto ${ }^{87}$. Sabe-se que a extinção era muitas vezes feita misturando-se à cal virgem a areia. Logo, era realmente necessário cuidado para que todos os componentes da mistura não contivessem os ditos sais. 
Por outro lado, caso os sais estivessem presentes no calcário a ser transformado em cal, eles desapareceriam por ocasião da calcinação, sendo dispensada a lavagem.

Alberti mencionou ainda que nas construções antigas utilizava-se cal, areia e pó de material cerâmico aparentemente em iguais proporções, sendo que, em sua opinião, se fosse acrescentada ainda uma porção de pó de travertino, a mistura ficaria mais sólida e resistente ${ }^{88}$, o que é verdade. Quanto à inclusão de material cerâmico nas argamassas, acredita-se que funcione para alterar a distribuição de porosidade do material, o que é até interessante no caso de argamassas de restauração, especialmente naquelas tidas como "de sacrifício" 89 . Isto porque permitem o crescimento de cristais de sais de maior tamanho em seu interior, demorando mais, conseqüentemente, para romper.

Ao tecer considerações acerca da restauração dos edifícios, Alberti indicou o uso de pasta de cal bastante fluida, misturada com pó de mármore, após lavagem do local com água pura, na renovação do revestimento de uma parede ou pavimento ${ }^{90}$.

Cataneo também forneceu algumas receitas de argamassas especiais:

- Para estuque: pasta feita com 2/3 de cal de mármore ou travertino e 1/3 de mármore moído finamente, ou seja, traço 1:0,5 (cal, pó de mármore), o mármore como substituto da areia ${ }^{91}$, opinião compartilhada por Vasari, seu contemporâneo ${ }^{92}$.

Na realidade, a função da areia na argamassa é a de carga. Logo, o pó de mármore poderia substituí-la perfeitamente. Este material apresenta como vantagens sobre a areia ser mais homogêneo e fino, o que propiciaria um melhor acabamento. No entanto, uma areia, sendo silicática - o que é mais freqüente -, mesmo heterogênea e um pouco mais grossa do que o pó de mármore, eventualmente resistiria mais do que este quando usada na confecção de uma argamassa em revestimento de fachadas, pois o carbonato de cálcio pode sofrer processo de dissolução, por lixiviação;

- Para cisternas, poços, fontes e reservatórios d'água:

[...] pegue-se uma parte de boa cal albazzana ${ }^{93}$, uma parte de saibro leve, uma parte de areia boníssima, de preferência a areia de rio 
muito bem lavada, acrescentando-Ihe pó de travertino: porque o faz melhor: e quando ele está na obra, não lhe dá mais problema ${ }^{94}$;

- Para interiores:

[...] pegue-se para cada dois alqueires ${ }^{95}$ de cal, dois outros de pó de telha, com meio alqueire de limalha de ferro: e se empaste e misturem juntos com decocção de casca de olmo cozido, mexendoa sempre por quinze dias; para que melhor fiquem embebidos e endureçam juntos: e esmalte-se depois o pavimento, ou qualquer outra coisa: e se passe todo dia borra de azeite, ou banha, com o misturador ou colher de pedreiro, de modo que se the apareça uma certa água branca, e então, sem mais tocá-lo, deixe secar completamente ${ }^{96}$.

Além do emprego do pó cerâmico, material tido como pozolana artificial pelo fato de conferir certa hidraulicidade à argamassa ${ }^{97}$, Cataneo recomendou a adição de escória de ferro à mistura, o que também foi notado em outros textos posteriores.

Francesco di Giorgio Martini sugeriu, ainda, outras argamassas especiais, que serviriam para dificultar a penetração da água nas construções:

- Também pegarai casca de olmo e 'fien greco', 'malva simita'98. Peguem-se dois alqueires de cal de mármore, um quarto de enxofre vivo, meio alqueire de pó de pedra pome, gesso cru colocado no calor e no cozimento [...] E quando a cal do mármore faltar, pode-se usar o pó desse ou outra cal ${ }^{99}$.

-Se for necessário algum estuque para vedar alguma greta ou fissura em fontes, cisternas ou em outras obras similares, pegue-se verniz líquido, cal viva, litargírio, pó de enxofre e mastique [... $]^{100}$.

O pintor e arquiteto italiano Gioseffe Viola Zanini (Ca. 1599-1631), ao descrever as argamassas, restringiu-se praticamente àquelas especiais, destinadas a revestimentos, sinteticamente indicadas a seguir. A respeito das argamassas de assentamento, teceu somente considerações sobre a pedra com a qual se devia fazer a cal e os tipos de areia a usar, e não mencionou traços. Com relação aos revestimentos, eis suas recomendações ${ }^{101}$ :

- Cal + pó de vidro; 
- Cal + pó de mármore (mistura usada, por exemplo, no revestimento de colunas que aparentavam ser feitas de mármores venados);

- Cal + pó de vidro + sapon da maschino ${ }^{102}$ - Tais ingredientes seriam dissolvidos na água, obtendo-se um líquido branco para caiar as paredes. Quando o revestimento estivesse pronto, deveria ser encerado com um pano;

- Cal + pó de telha ou pedra de Istria ${ }^{103}$ moída;

- Cal + escória de ferro ${ }^{104}$.

Com a inclusão de pó cerâmico, pó de pedra ou escória de ferro na mistura, as argamassas sofreriam alterações na sua distribuição de porosidade. O pó cerâmico reagiria com a cal, propiciando-Ihe características hidráulicas, e os demais ingredientes dariam maior resistência ao material.

Além de sugerir, em todos os casos, que a cal fosse branca, Zanini foi partidário que se seguisse a recomendação de Vitrúvio para só se usar a cal após longo período de extinção, de modo a não restarem pequenos grânulos de óxido de cálcio que viessem a sofrer hidratação na parede, o que levaria ao aparecimento de zonas estufadas no reboco em virtude da continuidade da reação de extinção in loco, com eventual perda de material.

Com relação à informação dada por André Félibien sobre a obturação de algumas estátuas de pedra, a sugestão foi que se fizesse uma mistura de gesso e pó da mesma pedra com a qual a estátua era feita ${ }^{105}$.

Enquanto no século XVII já se usava para obturação de pedras uma mistura de aglomerante com pó do mesmo tipo de pedra a ter a superfície regularizada, atualmente pode-se encontrar material espúrio sendo utilizado nas obturações de pedras em monumentos históricos, como por exemplo, reintegrações feitas com cimento tipo Portland (il. 1). O uso deste material é inconveniente principalmente pelo fato de conter grandes quantidades de sais solúveis, exceção feita ao cimento pozolânico.

Scamozzi concordou com os traços vitruvianos, assim como com a necessidade da areia ser isenta de argila e outras impurezas, para que se obtivesse uma argamassa de boa qualidade ${ }^{106}$.

Em um texto que descreve o processo de fundição da estátua eqüestre de D. José I, foram encontrados mais dois exemplos de argamassas usados 
ao longo dos séculos: para fixação do molde da mesma à cova, foi adotada uma argamassa com traço 1:0,5 (gesso, pó de barro queimado), para a qual também não foi indicada a quantidade de água a ser incluída na mistura ${ }^{107}$; outro exemplo foi o barro puro, apenas com água.

J. F. Blondel citou a nova argamassa descoberta por Loriot, que consistia, nada mais, nada menos, em uma argamassa (em pasta) de cal extinta e areia, ou cal extinta e pó cerâmico, traço 1:2, traçada pela segunda vez, ocasião em que era misturada com determinada proporção de cal viva em pó, obtida através do apiloamento de pedras calcárias muito bem cozidas. O procedimento era feito da seguinte forma: a argamassa existente era colocada em um recipiente, ao qual se acrescentava água para torná-la mais líquida. Feito isto, colocava-se cerca de um quinto do volume da argamassa em cal viva, misturando-as bem. Estava pronta a Mortier-Loriot, que segundo Blondel havia sido submetida a diversos ensaios por seu criador, tendo-se provado ser um material resistente, de secagem rápida e fácil trabalhabilidade, e que não produzia fissuras ao secar ${ }^{108}$.

O processo de confecção da Mortier-Loriot é peculiar porque, ao contrário dos demais, permite a colocação de água extra em uma argamassa já pronta, o que era recriminado por vários autores, e além disto, cal virgem. Não é especificada, entretanto, a quantidade de água utilizada na mistura em nenhuma das duas etapas.

\section{Traços recomendados}

Antigamente, não havia regras para a indicação das proporções entre os diversos componentes das argamassas, como se pode perceber da observação das várias referências encontradas na bibliografia consultada. Era comum, por exemplo, indicar-se o traço através das frações que cada componente ocupava do volume total do material produzido, e não por meio da correlação direta das quantidades dos componentes entre si, como é exemplificado através de uma citação do século XVII, escolhida ao acaso:

A boa argamassa deve ser composta de 2/3 de areia e 1/3 de cal [.... $]^{109}$.

Em outro exemplo aleatório, foram citadas as quantidades, em cestos, necessárias para a elaboração de uma argamassa: 
[...] se for area de rio [...] a dez cestos desta area se lhe deitarão cinco de $\mathrm{cal}^{110}$.

Quanto a estes e a outros traços observados nos documentos estudados, esclarece-se que, a título de simplificação, as diversas proporções mencionadas foram expressas da maneira que a atualidade exige, por norma: o aglomerante, primeiro valor na sequência dada, representado pela unidade, seguido do valor correspondente ao agregado. Isto para se conseguir uma padronização dos dados e para facilitar a leitura dos mesmos.

Sendo assim, ambos os exemplos supra-indicados poderiam ser simplificados, dizendo-se apenas "argamassas traço 1:2 (cal, areia)", em volume.

A representação atual é mais direta e não deixa dúvidas quanto às quantidades dos materiais a serem utilizados, enquanto às vezes, em textos anteriores ao século XX, as indicações fornecidas podem conduzir a eventuais erros de interpretação por parte do leitor, como no caso comentado por Alberti, ao falar das recomendações de Catão, Vitrúvio e Plínio:

Catão disse que para cada pé de trabalho se devem dar dois alqueires de areia e um de cal. Outros autores indicam proporções diversas. Vitrúvio e Plínio dizem que a areia vai misturada à cal de modo que esta seja um quarto, se a areia é de jazida, e um terço se é fluvial ou marinha ${ }^{111}$.

Realmente, no texto de Catão, que é anterior ao de Vitrúvio, encontrouse a informação seguinte:

[...] ela (argamassa) deve ser feita com um alqueire ${ }^{112}$ de cal e dois de areia por pé de comprimento destas paredes ${ }^{113}$.

No entanto, ratifica-se o que foi mencionado por Michel Frizot sobre as transcrições dos textos de Vitrúvio e Plínio analisados por Alberti: deve ter havido algum erro de compreensão das recomendações dos traços dados pelos mesmos serem, respectivamente, 1:3 (cal, areia de jazida) e 1:2 (cal, areia de rio ou mar) ${ }^{114}$, o que pode ser verificado através da análise individual do que cada um dos citados autores disse: os traços indicados seriam realmente aqueles recomendados por Vitrúvio, mas o que Plínio aconselhou foi 1:4, no primeiro caso, e 1:3, no segundo. Logo, estes autores não concordaram no traço ${ }^{115}$. 
A citação de Plínio, por sua vez, é outro exemplo de uma forma um tanto confusa de indicar-se a proporção entre cal e areia recomendadas:

Há areia de jazida, à qual se tem que adicionar $1 / 4$ do seu peso em cal; e areia de rio ou, de maneira alternativa, de mar, à qual deve ser adicionada um terço ${ }^{116}$ (Nesta tradução inglesa o traço foi dado em massa, como já mencionado, porém na tradução de Ludovico Domenichi consultada, isto não foi especificado).

Seria, seguramente, mais simples escrever que os traços eram:

1:4 (cal, areia de jazida) ou 1:3 (cal, areia de rio ou mar).

No Brasil, os traços das argamassas e concretos costumam ser representados com duas casas decimais, porque eventualmente estes traços podem ser explicitados em massa, e não em volume, enquanto que em Portugal o usual é ter-se esta representação em números inteiros, podendo entretanto encontrar-se raramente indicações com uma casa decimal, só que com valor variando unicamente de cinco em cinco décimos.

A metodologia brasileira pode, à primeira vista, parecer exagerada, e desnecessariamente detalhista, só que, para traços calculados em massa, e não em volume, os valores são mais confiáveis ${ }^{117}$. Além do mais, no caso de avaliações da composição de argamassas antigas através de análise química, julga-se mais conveniente usar esta representação, pois, já que é muito difícil - de fato, é praticamente impossível - determinar-se com precisão o traço original, é melhor permanecer-se com o valor encontrado através dos cálculos, mesmo que representem números fracionados, do que se aumentar ainda mais a margem de erro, através de nova aproximação.

Com relação ao traço mais indicado para as argamassas, Vitrúvio os diferenciou quanto ao tipo de areia usada, se de jazida 1:3 (cal, areia), se de rio ou de mar, 1:2 (cal, areia), enquanto que Faventinus e Palladius Rutilius recomendaram sempre 1:2 (cal, areia), sem fazer distinção entre as diversas proveniências do agregado. Por outro lado, os três indicaram a adição de pó cerâmico para melhorar a qualidade da argamassa, se feita com areia de rio ${ }^{118}$.

Alberti ainda recomendou o peneiramento da areia, caso houvesse necessidade de uma argamassa mais fluida, ou a adição de metade do volume da areia em saibro poligonal e pedra britada ${ }^{119}$, caso fosse 
requerido um material mais grosso ${ }^{120}$. Para Alberti, entretanto, a mistura de um terço de pó de tijolo produzia uma argamassa mais tenaz, como Vitrúvio e Plínio também afirmaram.

Como fator determinante na escolha do tipo de areia a ser utilizado na argamassa, Alberti aconselhou analisar-se o tipo de pedra a ser empregado na construção: no caso de pedras secas, a areia de rio; no caso de pedras úmidas, a de jazida. Quanto ao uso de areia de mar, Alberti não fez restrições relativas ao tipo de pedra a ser utilizado, mas sim à direção dos ventos: a parede não deveria ser exposta aos ventos meridionais, mas ao vento Norte ${ }^{121}$. Possivelmente, esta última indicação corresponderia aos ventos que possuíam maiores teores de umidade, na opinião de Alberti122, e que, conseqüentemente, terminariam por causar manchas nas argamassas, por higroscopicidade oriunda da presença de sais solúveis, principalmente do cloreto de sódio $(\mathrm{NaCl})$, existente no material marinho.

Foram encontradas, em alguns textos, citações sobre cal "treçada" ou "traçada". Negreiros mencionou o uso de camadas alternadas de cal "traçada" seca (em sacos) e pedras, até obter-se um monte artificial sobre o qual se ergueria o edifício, para fundações dentro da água, em locais onde não se pudesse adotar o sistema de estacas, como se teria feito por ocasião da construção da Torre do Bugio, na barra do Tejo ${ }^{123}$. Ressalta-se que Diogo Vellozo também falou das fundações da Torre do Bugio, assim como das que teriam sido feitas nos casos de um forte circular, já desaparecido, no Estado do Pará e do Forte de São Marcelo, também circular, em Salvador, só que não indicou o uso de cal, mas apenas de pedras secas ${ }^{124}$. As sondagens feitas há poucos anos no local onde está implantado o forte de São Marcelo, que fica dentro do mar, não acusam realmente a presença de cal, de modo que se acredita tal técnica tenha sido realmente utilizada.

De acordo com Azevedo Fortes, a expressão "cal no traço" (que teria o mesmo sentido que cal "treçada" ou "traçada"), significava cal misturada com areia, sendo que para ele a mistura deveria ser 1:2 (cal, areia) ${ }^{125}$. Esta opinião é corroborada pelos autores do Vocabulário técnico e crítico de arquitectura $^{126}$. Provavelmente o traço nem sempre era este, embora no caso da menção feita por Negreiros, fosse verdade. No tratado atribuído ao frei beneditino português Bernardo de São Bento (1624-1693), 
responsável pela construção do mosteiro de São Bento do Rio de Janeiro, escrito dezesseis anos após a conclusão das obras daquele monastério, por exemplo, parece que o sentido era diverso:

[...] As paredes que nesta obra estaó para fazer, em q he nesesario, aja a mayor fortaleza, que puder ser [...] se devem obrar [...] tendo grande cuidado no modo de terçar a cal, que a quantidade do saibro, que se Ihe botar, seia o q a bondade da cal puder sofrer; pois a que he feita de ostra sam, e limpa, poderá levar a quantia de saibro que se costuma; mas a que for de ostra podre, e çuja, nem presta nen pode sofrer o saibro de consideração, e faz fraca' ${ }^{127}$.

Segundo Silva-Nigra, o comentarista da publicação que tem como apêndice o referido tratado, "terçar" significaria "misturar três coisas; preparar a argamassa com água, saibro e cal". Na realidade, como Silva Nigra considerava como saibro a areia grossa misturada com pedrinhas roladas $^{128}$, o agregado seria graúdo e não miúdo.

Silva-Nigra não especificou que o traço devia ser sempre 1:2. Na própria passagem do texto de Frei Bernardo de São Bento, ficou claro que a quantidade de saibro dependia da qualidade da cal adotada. Logo, a indicação destes dois autores não se encaixa com a de Azevedo Fortes, nem tampouco com a do Vocabulário técnico. Na Bahia, no círculo dos mestres-de-obra e pedreiros, o termo "traçar" é utilizado com o sentido de "misturar todos os ingredientes de uma argamassa", não importando que ingredientes sejam estes, nem qual a quantidade de cada um. Fica, pois, a dúvida se realmente existia uma proporção determinada quando se mencionava "terçar".

No tratado anônimo, cuja autoria foi atribuída por Rafael Moreira (século XX) a António Rodrigues, foram relacionados os traços usados em finais do século XVI, em Portugal' ${ }^{129}$. Uma das indicações foi para se usar três cestos de areia e dois de cal, ou seja, adotar o traço 1:1,5 (cal, areia), sendo que o material deveria ser bem misturado ${ }^{130}$; outra, que a proporção entre areia e cal fosse 1:1, o que só seria possível se os materiais fossem de boa qualidade ${ }^{131}$. O próprio autor sugeriu, como pode ser verificado, dois traços distintos considerados como bons para as argamassas de cal e areia-1:1 e 1:1,5-, ambos diferentes, e mais fortes, do que aqueles preconizados pela maioria dos autores consultados. 
Philibert de l'Orme, no caso de argamassas de cal, indicou, para areias boas, que a proporção entre os dois ingredientes fosse 1:5 ou 1:7; para areias ruins, 1:2 ou 1:3; e para aquelas muito ruins, 1:1. Neste último caso, há uma grande contradição com relação a uma das referências constantes do texto atribuído a António Rodrigues, que recomendou traço idêntico para argamassas feitas com materiais de boa qualidade. Além disto, Philibert de l'Orme especificou que a areia deveria ser escolhida conforme a função que ia ter a argamassa: para fundações, paredes, rebocos, ou para ser misturada com pó cerâmico, formando o cyment ${ }^{132}$.

$\mathrm{Na}$ realidade, a sugestão para os traços 1:2 e 1:3 serem adotados apenas no caso de areias ruins entra em contradição com quase todas as demais, a começar pelas vitruvianas.

Manoel de Azevedo Fortes também mencionou o uso de argamassa traço 1:2 (cal, areia ou saibro), e traço 1:1 (ambos em volume, como de praxe), caso a cal fosse fraca. Quanto ao saibro, informou que deveria ser o melhor do país ${ }^{133}$. Logo, foi mais específico do que Philibert de l'Orme.

No que diz respeito à escolha do traço da argamassa conforme a qualidade dos materiais utilizados, encontrou-se também um conselho dado por D. Duarte, Rei de Portugal:

[...] hu' moyo de cal e dous d area, e mais e menos cal segundo a cal e o saybro for $[\ldots]^{134}$.

Segundo este conselho, o traço básico seria 1:2 (cal, areia), mas haveria alterações, a depender dos materiais utilizados. Nesta citação, ficou patente que o termo "saybro" era adotado como sinônimo de areia, e não com a conotação que tem hoje, pelo menos no Brasil: saibro, ou arenoso, é a denominação atribuída a um tipo de solo composto por uma mescla natural de areia e argila de base caulinítica.

No capítulo referente à cal do tratado de Palladio consta o seguinte:

Para fazer a argamassa, deve-se deste modo com a areia misturar; pegando-se areia de jazida, ponham-se três partes desta e uma de cal: se de rio ou de mar, duas partes de areia e uma de cal'135.

Este tratadista foi, pois, mais um dos adeptos dos traços vitruvianos 1:3 (cal, areia de jazida) e 1:2 (cal, areia fluvial ou marinha). 
É curioso o fato dos autores consultados indicarem a mesma proporção para argamassas feitas com areia de rio ou de mar. A primeira impressão que se tem é que estes dois tipos de material são bastante diferentes entre si, pois um é mais fino do que o outro e se apresenta sempre misturado com sais solúveis, com destaque para o cloreto de sódio, de modo que tem que ser abundantemente lavado para que tal componente nocivo seja eliminado. Em compensação, a areia de mar é, de maneira geral, mais livre de terra. Além do mais, os antigos preocupavam-se muito com a coloração das areias, e em geral a areia de mar é mais branca do que a de rio. Logo, supunha-se que esse fato tivesse sido levado em conta, o que raramente deve ter ocorrido, como pode ser notado através das diversas citações colhidas na bibliografia.

Francesco di Giorgio Martini, por sua vez, concordou com as proporções anteriormente citadas, só que não mencionou o emprego de areia de mar, quando se referiu ao traço. Fez apenas menção à possibilidade do emprego desta areia ao indicar a inclusão de pó cerâmico à mistura:
A sua mistura com areia de rio é: duas partes de areia e uma de cal; com as outras, três partes de areia e uma de cal. Deve-se compreender que, universalmente, se a toda cal misturada com areia fluvial ou marítima, for adicionada a terça parte de material cerâmico pulverizado ou de antigas telhas, muito mais tenaz se tornará. Quando se tivesse que preparar material para fazer cisterna, sua proporção com relação à areia que procura é esta: duas partes de cal e cinco de areia áspera, ou seja, subdupla sesquialtera ${ }^{136}$.

Esclarece-se que Francisco Saraiva informou que subdupla significa "que é contido duas vezes em outro (número)", enquanto que sesquialtera indica "que contém outro tanto, e mais metade, um e meio"137.

Corrado Maltese, o comentarista de uma publicação recente do tratado de Martini, disse que as informações referentes aos traços dadas por este italiano estavam conforme Plínio (Nat. Hist., XXXVI, 186; XXXVI, 175; XXXVI, 173) e Vitrúvio (VIII, 6, 14), e seriam 1:2 (cal, areia de rio) e 1:3 (cal, outras areias) ${ }^{138}$. No entanto, conforme já comentado anteriormente, Vitrúvio e Plínio não tinham opinião concordante quanto aos traços recomendados: para Vitrúvio, os traços deviam ser 1:3 (cal, areia de jazida) e 1:2 (cal, areia de rio ou de mar), enquanto que, para Plínio, seriam 1:4 (cal, areia de jazida) e 1:2 (cal, areia de rio ou mar). 
Além disto, segundo Vitrúvio e Plínio, o traço, no caso do uso da areia de mar, seria o mesmo que aquele à base de areia de rio; já Martini, falou claramente em areia de rio e em outras areias, como pode ser verificado na indicação anteriormente transcrita. Logo, as areias de jazida e de mar estariam nessa última categoria.

No texto de Mattheus do Couto, recomendou-se que as argamassas fossem feitas com o traço 1:1,5 (cal, areia), desde que a cal fosse oriunda de pedra lioz; para cal feita de pedra mais branda, o traço indicado foi 1:1 (cal, areia), e 1:2, no caso da utilização de uma pedra de maior dureza139. Repetem-se, pois, as indicações, em termos numéricos, do já citado códice estudado por Rafael Moreira, assim como a crença que a cal seria tanto melhor, quanto mais dura fosse pedra. É certo, entretanto, que quanto mais forte for a cal, a argamassa com ela preparada pode conter mais areia, sem prejuízo da resistência.

Na edição de 1789 do texto de Branca, consta que a argamassa feita com cal de pedra albazzana e areia de rio deveria ter o traço 1:2, e 1:3, caso a areia tivesse outra proveniência ${ }^{140}$. Desta indicação - que não apareceu na publicação espanhola do ano seguinte, pois o tradutor para o espanhol, além de omitir muitas passagens específicas sobre materiais italianos, conforme o mesmo destacou, desconhecia aquela edição italiana $^{141}$ - deduz-se que a argamassa feita com areia de rio era realmente considerada como mais fraca, como já ensinado por outros autores.

André Félibien, além de ratificar as recomendações feitas por Vitrúvio com relação ao preparo da cal, tipos de areia existentes, uso de pozolana e de fragmentos de material cerâmico, fez referências a traços de argamassas diversas, a depender da qualidade da cal empregada ${ }^{142}$, e o estuque composto por mármore pulverizado e cal, para a execução de esculturas e ornatos arquitetônicos ${ }^{143}$.

Pfeffinger, por sua vez, preferiu os traços 1:1 e 1:3 (cal, areia) para alvenarias, no caso de fundamento em hum lugar aquatico, e não propôs a adição de pó de tijolo:

[...] os enchelares devem ter boas juntas, \& se unirão bem humas às outras com gatos de ferro, \& primeiro assentadas com cal, cuja composição pede que seja neste caso tanto de cal como de area, \& outras vezes se faz com tres partes de area, \& huma de cal ${ }^{144}$. 
Notou-se, pela afirmação de Pfeffinger, que as proporções recomendadas foram parcialmente diferentes daquelas dos textos anteriormente citados ${ }^{145}$, e que este autor não deu justificativa alguma para que assim se procedesse. Os outros escritores, pelo menos, indicaram a variação do traço a depender da procedência da areia - se de rio, de jazida ou de mar -, ou da qualidade da cal - se gorda ou magra.

Foi possível constatar, no texto atribuído a Fremin, datado de 1702, que era já recriminada a adoção de traços padronizados. Além disto, o mesmo autor sugeriu que fosse ao menos verificada a qualidade da areia disponível no local a ser construída a edificação:

[...] os arquitetos cometem, segundo minha opinião, faltas, quando sem refletir sobre a areia que se encontra no lugar onde lhes convêm construir, dizem em suas especificações que há simplesmente que colocar 2/3 de areia e 1/3 de cal: cometem mais uma, quando independentemente deste exame, indicam uma areia sem primeiramente a ter bem avaliado ${ }^{146}$.

Atualmente, não se usa com tanta freqüência a cal nas argamassas. No entanto, nas argamassas cujo aglomerante é o cimento tipo Portland, costuma-se, em obras de pequeno porte ou pequenas reformas, adotar traços padronizados, como em épocas passadas, mesmo sem se saber a proveniência, ou qualidade, dos materiais. O correto seria, em todos os casos, definir-se o traço a ser utilizado em massa, com base na granulometria do agregado, no seu teor de umidade e no inchamento, e utilizar-se, na obra, a medição dos materiais em volume.

De acordo com as recomendações de Cataneo, os traços adotados para as argamassas deveriam ser os vitruvianos: 1:3, se fosse usada areia de jazida, e 1:2, se a areia fosse de rio ou mar. Entretanto, Cataneo foi taxativo quanto à utilização da areia do mar, que deveria ocorrer apenas se fosse imprescindível, e se isto acontecesse, que fosse bem lavada de modo que os sais fossem expurgados. Caso contrário, a obra deveria ser erguida muito lentamente, pois:

[...] não só dificilmente se seca, mas por liquefazer-se a salsugem, ao tempo das chuvas arruina-se sozinha: o que, com o tempo, não ocorrerá assim facilmente ${ }^{147}$.

Mathias Ayres chamou a atenção para o uso despreocupado de qualquer tipo de areia, fosse ela fina ou grossa, sem que se verificasse 0 volume que ocupava ${ }^{148}$. 
As argamassas cujos traços são medidos em volume úmido, como é ainda freqüente hoje em dia, por vezes, apresentam problemas após endurecidas. Isto sem falar que o seu custo é mais elevado ${ }^{149}$. O ideal é que o traço seja dado em massa ${ }^{150}$, calculando-se o teor de umidade dos agregados miúdos, porém podendo a medição ser eventualmente feita, na obra, em volume. Esta recomendação é decorrente do fato de que a massa de um material é constante para toda uma região, enquanto que o seu volume varia a depender da massa unitária do material e do seu módulo de finura. Além disto, o inchamento da areia é regular, e pode ser calculado, mas o do arenoso e do caulim, por exemplo, materiais de uso freqüente, hoje em dia, em argamassas, não. Deste modo, dependendo do percentual de umidade dos agregados miúdos, o volume por eles ocupado sofre variação, requerendo consumos diferentes de aglomerante. Fato similar ocorre em virtude do número de finos e da forma dos grãos dos referidos agregados ${ }^{151}$.

Ainda no que diz respeito aos traços das argamassas, encontrou-se um texto bastante interessante de meados do século XVIII, escrito pelo mestre de pedreiro português Valério Martins de Oliveira ${ }^{152}$. Nele foram registrados, por exemplo, os traços de argamassas que se tinha o costume de empregar àquela época, em Portugal. Pôde ser notado, através da leitura do texto, que o rendimento do material pronto variava, donde se pode inferir que, ou alguns práticos empregavam camadas mais espessas de argamassa, ou os materiais utilizados eram de qualidades diferentes.

Scamozzi recomendou que as argamassas fossem feitas da seguinte forma:

[...] destemperando a cal pouco a pouco com a água [...] então depois bem remexida à parte, se lhe coloca a areia dois tantos; ou três tantos da cal, segundo o que suportará a bondade de uma e da outra, e de novo se acrescenta, e se destempera com água; porque coisa certa é, que ela fica sempre melhor como a pasta do pão bem amassado ${ }^{153}$.

Ao comparar-se esta informação com as do texto atribuído a Fremin, indicadas a seguir, e as do Cours d'architecture, de J. F. Blondel, verificouse que estes autores discordaram da opinião de Scamozzi: este autor recomendou a adição de mais água à mistura, porém os outros dois recriminaram qualquer água a ela adicionada, com a justificativa que isto faria apenas com que a cal perdesse a sua força. A única água que devia 
ser utilizada para o preparo da argamassa era aquela em que a cal fosse extinta, pois se uma água limpa fosse acrescentada à mistura, funcionaria apenas para "[...] enfraquecer e fazer desaparecer os espíritos ígneos da cal [...]" da cal, do mesmo modo que ocorreria se a areia fosse usada úmida ${ }^{154}$.

A quantidade de água acrescentada à mistura não apresentaria a influência negativa mencionada. Se fosse acrescentada mais água do que o necessário, a argamassa ficaria mais fluida, apresentando mais facilmente problemas decorrentes da perda de água por ocasião da secagem (retração) ${ }^{155}$. Todavia, a colocação de água na mistura de cal e areia apenas uma única vez, por ocasião da extinção, e o uso de areia limpa, seca e sem argila, foram posições defendidas, igualmente, em outros textos, como naquele atribuído a Cormontaigne ${ }^{156}$.

No caso das argamassas contemporâneas que contém cimento tipo Portland, a alteração do fator água-cimento leva a uma mudança nas características do material, tanto fresco, quanto após o endurecimento, o que pode causar, em última instância, a ruína da edificação. Mas a quantidade deste líquido presente na mistura com cal não conduz a tantos problemas na argamassa formada, como ocorre quando o cimento tipo Portland é usado como aglomerante. Entretanto, destaca-se que a reação de endurecimento da argamassa de cal só se realiza em ambiente úmido (e na presença de gás carbônico), de modo que a água desempenha papel fundamental na mistura.

A observação final encontrada no texto atribuído a Fremin sobre o assunto foi que, após oito dias de concluídos os trabalhos com determinada argamassa, podia ser verificado se ela era boa ou não ${ }^{157}$. Esta era uma dedução, ao que parece, muito precipitada, pois como o processo de carbonatação da cal é muito lento, em oito dias não se teria um resultado satisfatório. De qualquer modo, pelo menos já havia uma preocupação com a realização de um teste prático para se ter uma idéia do comportamento do material, o que é louvável.

Hoje, além de ensaios de resistência à compressão e à tração ${ }^{158}$, que podem ser feitos nas argamassas, existe, dentre outros, o teste do arrancamento ${ }^{159}$, exatamente para verificar a aderência das argamassas de revestimento ao substrato, ou de um revestimento cerâmico à argamassa que o sustenta. 


\section{Notas}

1 Termo originário do latim arenatum.

${ }^{2}$ EÇA, Mathias A. R. da Silva de. Problema de architectura civil. Lisboa: Antonio Rodrigues Galhardo, 1777. Parte II, Cap. X, p. 148/149.

${ }^{3}$ Ver no capítulo sobre pozolanas algumas considerações acerca do significado do termo massapez.

${ }^{4}$ CASTANHEIRA DAS NEVES, J. da P.. «Memoria sobre as investigações experimentaes e ensaios de resistencia dos materiaes de construcção». Revista de Obras Públicas e Minas, Nov./Dez. 1893, t. XXIV, p. 497-522. p. 501.

${ }^{5}$ Conhecido, geralmente, apenas como André Félibien.

${ }^{6}$ BELIDOR, Bernard Forest de. Dictionnaire portatif de l'ingenieur. Paris: Charles-Antoine Jombert, 1755. p. 193 - Mortier. C'est un composé de chaux \& de sable, ou de chaux \& de ciment, pour liaisonner les pierres. On dit que le mortier est gras, lorsqu'il y a beaucoup de chaux.

${ }^{7}$ Maiores informações sobre o assunto no capítulo Outros Constituintes das Argamassas.

${ }^{8}$ RODRIGUES, Francisco de Assis. Diccionario technico e historico de pintura, esculptura, architectura e gravura, Lisboa, Imprensa Nacional, 1875. p. 56.

${ }^{9}$ DAVEY, Norman. A history of building materials. Londres: Phoenix, 1961. Cap. XIV, p. 120

${ }^{10}$ SANTIAGO, Cybèle Celestino. O solo como material de construção, Salvador, EDUFBA, 2001. Parte II, p. 55.

${ }^{11}$ OLIVEIRA, Mário Mendonça de. «Uso de resinas na conservação». In: OLIVEIRA, Mário Mendonça de, SANTIAGO, Cybèle Celestino, LEAL, João Legal, Rudimentos para oficiais de conservação e restauração. Rio de Janeiro: ABRACOR, 1996, p. 97-116. p. 98.

${ }^{12}$ DE VILLE, Antoine. Les fortifications. Lyon: Phillipe Borde,1641. Parte I, L. I, p. 89. - Les murailles de Charra, ville d'Arabie, estoient encore plus merveilleuses, care elles estoient toutes massives de pierre de sel, \& n'avoient autre mortier que de l'eau pure pour les assembler.

${ }^{13}$ [FREMIN]. Memoires critiques d'architecture. Paris, Charles Saugrain, 1702. p. 83/84 . Les pierres \& les moëlons fraîchement tirez de la carriere occasionnent aussi une tromperie dans les bâtimens; la chaux ou le plâtre qui sert à les attacher les uns aux autres, n'ayant leur action que par l'effet de leur chaleur, dés qu'elle se trouve combattuë par l'humidité ou par la froideur qu'il y a dans ces pierres, il est évident que ce sont deux ennemis qui empêchent l'accrochement du sable \& des sels qui sont dans le sable e dans le plâtre \& que par cet empêchement la chaux perd tout l'effet de son action.

${ }^{14}$ Umidade ascendente, decorrente de infiltrações, proveniente de águas de chuvas etc..

${ }^{15}$ Evidentemente, a areia pode não ser de origem marinha e conter sais, por contaminação.

${ }^{16}$ Hidratado, semi-hidratado, di-hidratado.

${ }^{17}$ VARRON, Marco Terencio. De las cosas del campo, trad. de Domingo Tirado Benedí. México: UNAM, 1945. Cap. LVII, p. 55. - Las paredes y el suelo deben revestirse con una capa de masa formada con mármol machacado, o al menos de arcilla mezclada con paja de trigo y orujo de olivas. 
${ }^{18}$ VITRUVIO, De architectura. L. II, Cap. IV, V e VI, respectivamente (na versão traduzida por Blánquez).

19 VITRUVIO, Marco Lucio. Los diez libros de arquitectura, tradução, prólogo e notas de Agustín Blánquez. Barcelona: Iberia, 1955, L. II, Cap. IV, p. 43.

${ }^{20} / d$., ibid., L. II, Cap. V, p. 44 - Foi feita a ressalva que a argamassa seria mais firme e sólida, no caso do uso de areia de rio ou de mar, se a ela fosse adicionada uma terceira parte de pó de tijolos peneirado, de modo que o traço recomendado passava a ser 1:2:1 (cal, areia, pó de tijolos), em volume.

${ }^{21}$ VITRUVIO POLLIO, Marco. I dieci libri dell'architettura, tradução e comentários de Daniel Barbaro. Veneza: Francesco Marcolini, 1556. L. II, Cap. V, p. 47.

22 MARTINI, Francesco di Giorgio. «Architettura civile e militare», Trattati di architettura ingegneria e arte militare, comentários de Corrado Maltese. Milão: II Polifilo, 1967. v. III, t. II, tratado I, p. 317, nota 6 - "«testi»: latinismo proveniente de «testa» per indicare ogni oggetto o frammento di oggetto in terracotta". - «testi»: latinismo proveniente de «testa» para indicar todo objeto ou fragmento de objeto em cerâmica.

${ }^{23}$ VITRÚVIO. Os dez livros de arquitectura, trad. de Helena Rua, $1^{\text {a }}$ ed.. Lisboa: IST, 1998. L. II, Cap. V, p. 37.

${ }^{24}$ VITRUVIO, Marco Lucio. Los diez libros de arquitectura, tradução de Agustín Blánquez..., L. VII, Cap. IV, p. 180.

${ }^{25}$ VITRÚVIO. Os dez livros de arquitectura, trad. de Helena Rua, L. II, Cap. IV, p. 42.

${ }^{26}$ FURLAN, Vinicio. «Experiences pratiques avec des crepis a base de chaux», Mortars, cements and grouts used in the conservation of historic buildings. Roma: ICCROM, 1981, p. 9-18. p. 13.

${ }_{27}^{27}$ PETRUCCI, Eládio G. R. . Materiais de construção, 8ª ed.. Porto Alegre: Globo, 1987. Cap. VII, p. 352.

${ }^{28} \mathrm{~A}$ argamassa deve ser impermeável à água, porém permeável ao vapor, de modo que a parede possa "respirar", ou seja, eliminar os resíduos de umidade por ventura presentes no seu interior.

${ }^{29}$ No caso do ligante ser a cal.

${ }^{30}$ Por exemplo, assentamento de pedras em fundações, em paredes, em locais secos, em locais úmidos; revestimento interno, revestimento externo, de parede, de piso.

${ }^{31}$ Ou Daviler, como freqüentemente encontra-se escrito. Arquiteto do rei da França, traduziu o livro de Scamozzi. Escreveu um texto intitulado Cours d'architecture, publicado em Amsterdã, no século XVII. Tal texto foi composto em dois tomos, sendo o segundo um dicionário de termos arquitetônicos.

32 D'AVILER, Augustin Charles. Cours d'architecture, $3^{\mathrm{a}}$ ed., Amsterdam, George Gallet, 1699. t. I, Parte I, p. 213 - [...] mortier ou matiere qu'on employe humide, autant pour remplir les joints \& le vuide [sic] que se rencontre entr'elles, que pour les lier les unes avec les autres // [...] argamassa ou matéria que empregamos úmida, tanto para preencher as juntas e os vazios que se encontram entre elas, quanto para as ligar umas com as outras.

${ }^{33}$ VASCONCELLOS, Ignacio da Piedade (Pe.). Artefactos symmetriacos, e geometricos. Lisboa Occidental: Joseph Antonio da Sylva, 1733. L. IV, Cap. XVI, p. 377/378. 
${ }^{34}$ OLIVEIRA, Mário M. de; SANTIAGO, Cybèle C., JESUS; José Augusto Brito de. OLIVEIRA; Teresa Cristina M. de. «Argamassas bastardas: origens e propriedades», Anais da $2^{a}$ Semana Pensando em Argamassas. Salvador: DCTM/EPUFBA, Março/96, p. 24-34. p. 24.

${ }^{35}$ BELIDOR, Bernard Forest de. La science des ingenieurs. Paris: Claude Jombert, 1729. L. III, Cap. V, p. 18.

${ }^{36}$ [FREMIN]. Memoires critiques d'architecture..., p. 118.

${ }^{37}$ BLONDEL, Jacques-François. Cours d'architecture. Paris: Desaint, 1777. v. VII, t. V, De la maçonnerie, Cap. V, Art. II, p. 186.

${ }^{38}$ PAPACINO, Alessandro Vittorio d'Antoni. Institutions physico-mechaniques, Strasbourg, Bauer \& Treuttel, 1777. t. I, Cap. IV, p. 63.

${ }^{39}$ Conforme Capra, VITRÚVIO, L. II, Cap. V e VI; PALLADIO, L. I, Cap. IV. Não foram indicadas, entretanto, as edições consultadas.

${ }^{40}$ CAPRA, Alessandro. La nuova architettura civile e militare (Cremona, Pietro Ricchini, 1717), fac-símile, Sala Bolognese, Arnaldo Forni, 1987. t. I, L. II, Cap. IV, p. 95.

${ }^{41}$ A depender do tipo considerado, a pedra lioz pode conter elementos argilosos.

42 NEGREIROS, Jozé Manuel de Carvalho. Jornada pelo Tejo, [Lisboa], Cód. 80 (AHM), 1792. fls. 143.

${ }^{43}$ NERO, Jozé Manuel G.; APPLETON, Júlio António; GOMES, Abdias M.. «As argamassas tradicionais no parque edificado de Lisboa: uma colaboração para o seu conhecimento", Anais do $2^{\circ}$ ENCORE. Lisboa: LNEC, 1994. v. I, p. 221-232.

${ }^{44}$ REIS, Maria Olinda Braga; SILVA, António Santos. «Caracterização química e microestrutural de argamassas antigas", Atas do $2^{\circ}$ ENCORE, Lisboa, LNEC, 1994, v. I, p. 319-330. p. 330 - [...] com base nos conhecimentos actuais existentes sobre a composição de argamassas antigas, [sabe-se] que era frequente a utilização de misturas de cal aérea e adições activas, ricas em sílica e óxidos de alumínio e ferro, tais como: argilas, produtos cerâmicos moídos, terras vulcânicas, terras de diatomáceas. Durante o processo de endurecimento dessas argamassas, parte da cal combinava-se com os componentes activos de carácter pozolânico dessas adições, com formação de silicatos e aluminosilicatos de cálcio hidratados não cristalinos, sendo a sua composição dependente, naturalmente, da natureza da adição e do modo de preparação das argamassas (grifo não existente no texto original).

${ }^{45}$ DOMASLOWSKI, W.. «The properties of lime and cement mortars modified by metakaolinite", Anais do 8th International Congress on Deterioration and Conservation of Stone, Berlim, Josef Riederer, 1996. v. III, p. 1529-1534. p. 1529.

${ }^{46}$ BONAZZI, Achile; FIENI, Laura. «Uso e fortuna delle malte d'argilla nell'Italia settentrionale: prime ricerche su Cremona", Revista Trimestral e di Restauro. Milão: Franco Angeli, 1995, n. 1, p. 44-52.

${ }^{47}$ OLIVEIRA, Teresa Cristina M. de. «Argamassas bastardas» e suas características físicas, químicas e tecnológicas. Salvador, Universidade Federal da Bahia, 1995. Dissertação de mestrado. p. 85.

${ }^{48}$ LUNA, Maria Isabel. «Consolidation of traditional plasters: a laboratory research», Atas da $7^{a}$ Conferência Internacional sobre o Estudo e Conservação da Arquitectura de Terra. Lisboa: DGEMN, 1993, p. 410-416. p. 410. 
${ }^{49}$ FRIZOT, Michel. «L'analyse des mortiers antiques: problemes et resultats», Mortars, cements and grouts used in the conservation of historic buildings. Roma: ICCROM, 1982, p. 331-339. p. 334.

50 Temperatura superior a $900^{\circ} \mathrm{C}$.

51 SANTIAGO, Cybèle Celestino. Aditivos orgânicos em argamassas antigas. Salvador, UFBA, 1992. Dissertação de mestrado. Cap. V, p. 42.

${ }^{52}$ BELIDOR, Bernard Forest de. La science des ingenieurs..., L. IV, Cap. XI, p. 81.

${ }_{53}$ Para facilitar a exemplificação, está-se considerando, de maneira geral, que o hidróxido existente nas argamassas é apenas o de cálcio, embora freqüentemente o hidróxido de magnésio esteja presente na composição da mistura. O mesmo princípio foi adotado ao mencionar a cal viva como sendo formada apenas de óxido de cálcio.

54 VITERBO, Francisco Marques de Sousa. Diccionário histórico e documental dos arquitectos, engenheiros e construtores portugueses, Lisboa, Imprensa Nacional/Casa da Moeda, 1988. v. I, p. 255 - De acordo com Souza Viterbo, Mattheus do Couto era arquiteto do Santo Ofício.

${ }^{55}$ COUTO, Mattheus do (o Velho). Tractado de architectura, [Lisboa], Cód. F.7752 (BNL), 1631. L. II, Cap. II, p. 28.

${ }^{56}$ FERREIRA, Carlos Augusto Pinto. Engenheiro de algibeira, $5^{\mathrm{a}}$ ed.. Lisboa: A. M. Pereira/ Livraria Editora, 1903. p. 75.

${ }^{57}$ VITRUVIO, Marco Lucio. Los diez libros de arquitectura, tradução de Agustín Blánquez..., L. VII, Cap. I, p. 171 a 174.

${ }^{58}$ /d., ibid., L. VIII, Cap. VII, p. 218 // VITRUVIUS, On architecture, trad. de Frank Granger, versão bilingüe latim/inglês, Cambridge/Londres, Harvard University Press/William Heinemann, 1962. L. VIII, Cap. VI, p. 186/187 - Blánquez não disse que era cal viva, mas Granger, sim (quicklime), e na versão latina apresentada no seu texto isto está bem claro (calce viva).

${ }^{59}$ PLOMMER, Hugh. Vitruvius and later Roman building manuals. Cambridge: The University Press, 1973. p. 28

${ }^{60}$ VITRUVIO, Marco Lucio. Los diez libros de arquitectura, tradução de Agustín Blánquez..., L. VII, Cap. III, p. 176.

${ }^{61}$ Id., ibid., L. V, Cap. XIII, p. 134/135 // VITRUVE, Les dix livres d' architecture, correção, tradução e notas de Claude Perrault (Paris, Jean Baptiste Coignard, 1684), fac-símile, Bruxelas/Liège, Pierre Mardaga, 1979. L. V. Cap. XII, p. 196 // VITRUVIUS, On architecture, tradução de Frank Granger..., L. V, Cap. XII, p. 312/313 - Informa-se que Blánquez, ao invés de usar o termo pozolana, disse simplesmente "terra da região de Cumas/promontório de Minerva"; Perrault indicou que tal terra era pozolana, o que foi ratificado por Granger, que esclareceu ainda que o local ao qual Vitrúvio se referiu correspondia à região da cidade italiana de Sorrento, na costa Amalfitana.

${ }^{62}$ Caius Plinius Secundus.

${ }^{63}$ PLÍNIO (o Antigo). Historia naturale, trad. de Ludovico Domenichi, Veneza, G. Ferrari, 1561/1568. L. XXXI, Cap. VI, p. 985 - Utilissima cosa è condurre l'acqua dalle fonti per doccioni grossi due dita, che si commettano l'un con l'altro in forma di bossolo, in modo, che'l superiore entre, intonacati di calcina viva con olio. 
${ }^{64} \mathrm{ALBERTI}$, Leon Battista. De re ædificatoria (Florença, 1495), trad. de G. Orlandi, introdução e notas de P. Portoghesi, L'architettura. Milão: II Polifilo, 1966. v. I, L. III, Cap. XVI, p. 258.

${ }^{65}$ /d., ibid., v. II, L. X, Cap. XVII, p. 998.

${ }^{66}$ Não se constatou, entretanto, recomendação alguma de seu uso em mistura com cal viva.

${ }^{67}$ Possivelmente (vetriolo romano) sulfato de cobre, segundo Portoghesi, o comentarista da edição consultada do tratado de Alberti.

${ }^{68}$ MARTINI, Francesco di Giorgio. «Architettura civile e militare»..., v. III, t. I, tratado I, p. 113. - Diensi detti cannoni o tomboli in questo modo murare. In prima in nelle loro commensure di questa composizione investirai: piglisi olio di lino, calcina viva, insieme misti, e com questo in nelle commensure sue è da serrare. E non possendo avere dell'olio di lino piglisi del comuno. A questo medesimo piglisi calcina viva parti due, cenare di cerro parte una, e tanto olio che impastire si possa. Item piglia calcina parti due, cenare di cerro parte una, vetriolo romano parte mezza, e tanto olio che per imbastire basti.

${ }^{69}$ RODRIGUES, Maria João Madeira; SOUSA, Pedro Fialho de; BONIFÁCIO, Horácio Manuel Pereira. Vocabulário técnico e crítico de arquitectura, $2^{\mathrm{a}}$ ed. (rev.). Coimbra: Quimera 1996. p. 258.

${ }^{70}$ SILVA-NIGRA, Clemente da (D.). «Francisco de Frias da Mesquita, engenheiro-mor do Brasil», Revista do SPHAN, n. ${ }^{\circ}$ 9, 1946. p. 45.

${ }^{71}$ AZEVEDO FORTES, Manoel de. O engenheiro português (Lisboa, Manoel Fernandes da Costa, 1729), fac-símile. Lisboa: Direcção da Arma de Artilharia, 1993. t. II, L. VI, Cap. IV, p. 285.

${ }^{72}$ RIEGER, Christiano (Pe.). Elementos de toda la architectura civil. Madrid: Joachin Ibarra, 1763. Parte IV, Cap. I, p. 226/227. - El mas simples es de polvo de ladrillo, y cal, y para unir piezas de estatuas, ò una piedra con otra, ò piedra con madera, ò tambien madera con madera, es cosa muy buena, y firme el quajaron, que se hace de quajada de leche, y cal viva, la qual se mezclarà de modo, que haga una massa muy aquosa.

${ }^{73}$ MELENDEZ, Bermudo; FUSTER, José Maria. Geologia, $3^{\mathrm{a}}$ ed. (corrigida e ampliada, $2^{\mathrm{a}}$ tiragem). Madrid: Paraninfo, 1975. Parte I, Cap. X, p. 282 e Parte II, Cap. XVIII, p. 569 Conforme este texto, as "tobas" seriam rochas que se formam a partir de depósitos de carbonato de cálcio sobre vegetais subaquáticos, ou seriam rochas piroclásticas oriundas da consolidação de cinzas vulcânicas e pequenas pedras.

${ }^{74}$ Litargírio, ou seja, protóxido de chumbo fundido e cristalizado.

${ }^{75}$ RIEGER, Christiano (Pe.). Elementos de toda la architectura civil..., Parte IV, Cap. I, p. 226. - Un quartillo de polvo de piedra de canterìa, ocho quartillos de limaduras de hierro, doce quartillos de cal viva, seis quartillos de harina de toba, quatro quartillos de harina de vidrio, ocho quartillos de polvo de ladrillo, y quatro onzas de litargirio; todo esto molido, y passado por un zedazo de cerdas de caballo, se amassarà con tres azumbres de aceyte de linaza: despues se bate bien, hasta que estè una massa blanda, y se le mezclaràn, y batiràn unos pelos de cabra sylvestre, ò de algodòn.

${ }^{76}$ PLíNIO (o Antigo). Historia naturale, trad. de Ludovico Domenichi. Veneza: G. Ferrari, 1561/1568., L. XXXVI, Cap. XXIII, p. 1150. - [...] se dee [sic] dare la quarta parte di calcina. Ma aquelle de'fiumi, o del mare, la terza parte; et se vi aggiugne la terza parte di vasi pesti, sarà miglior lavorio. 
77 PLINIUS, C. Secundus. Natural history, Livros XXXVI-XXXVII, publicação bilingüe sob a resp. de D. E. Eichholtz. Londres: Oxford Press, 1962. v. X. Cap. XXIII, p. 139 - Of sand, there are three varieties: there is quarry sand, to which has to be added one-quarter of its weight in lime; and river or alternatively sea sand, to which must be added one-third // Há três variedades de areia: existe areia de jazida, à qual deve ser acrescentado um quarto do seu peso em cal, e areia de rio, ou alternativamente, de mar, à qual deve ser adicionado um terço. (grifo não existente no texto original)

${ }^{78}$ Harena tria genera: fossicia, cui quarta pars calcis addi debet, fluviatili aut marinae tertia. Si et testae tusae tertia pars addatur, melior materia erit.

${ }^{79}$ PLÍNIO (o Antigo). Historia naturale, trad. de Ludovico Domenichi..., L. XXXVI, Cap. XXIIII, p. 1151.

${ }^{80}$ ALBERTI, Leon Battista. De re ædificatoria, trad. de G. Orlandi..., v. II, L. VI, Cap. IX, p. 498.

${ }^{81}$ Com algumas polegadas, talvez um palmo.

${ }^{82}$ ALBERTI, Leon Battista. De re ædificatoria, trad. de G. Orlandi..., v. II, L. VI, Cap. IX, p. 498 - Apesar de não ter sido mencionado, o aglomerante na composição destas camadas, possivelmente, foi a cal. A outra opção seria o gesso.

${ }^{83}$ Forma de reduzir os vazios existentes na superfície a revestir, ao mesmo tempo que funcionava como uma interface entre o substrato e o revestimento, propiciando-lhe uma aderência maior.

${ }^{84}$ ALBERTI, Leon Battista. De re ædificatoria, trad. de G. Orlandi..., v. II, Livro VI, Cap. X, p. 506.

${ }^{85}$ /d., ibid., v. II, Livro VI, Cap. X, p. 506/508. - [...] irrorare più e più volte la calcina com acqua bollente, si da spogliarla della salsedine e da renderla più tenera e viscosa.

${ }^{86}$ PLOMMER, Hugh. Vitruvius and later Roman building manuals ..., p. 36.

${ }^{87}$ EÇA, Mathias A. R. da Silva de. Problema de architectura civil..., Parte II, Cap. X, p. 174/ 175 // NEGREIROS, Jozé Manuel de Carvalho, Jornada pelo Tejo..., fls. 143v/144.

${ }^{88} \mathrm{ALBERTI}$, Leon Battista. De re ædificatoria, trad. de G. Orlandi..., v. I, L. III, Cap. XVI, p. 258 - [...] un único strato di materiale consistente in un miscuglio di calce, sabbia e polvere di terra cotta, nella misura di un terzo per ciascuno (cosi almeno suppongo). Mi risulta che tali ricoperture divengono più solide e resistenti se vi si aggiunge polvere di travertino nella mistura di un quarto // [...] uma única camada de material consistindo em uma mistura de cal, areia, e pó de material cerâmico, na medida de um terço para cada um (assim ao menos suponho). Me parece que tais revestimentos tornam-se mais sólidos e resistentes se se acresenta pó de travertino na mistura de um quarto.

${ }^{89}$ OLIVEIRA, Mário M. de; SANTIAGO, Cybèle C.; JESUS, José Augusto Brito de; OLIVEIRA, Teresa Cristina M. de. «Argamassas bastardas: origens e propriedades», Anais do 10 Simpósio Brasileiro de Tecnologia das Argamassas. Goiânia: UFG/ANTAC, Ago/95, p. 43-52. p. 51 // OLIVEIRA, Mário M. de; SANTIAGO, Cybèle C.; JESUS, José Augusto Brito de; OLIVEIRA, Teresa Cristina M. de; «Argamassas bastardas: origens e propriedades»..., p. 34.

${ }^{90} \mathrm{ALBERTI}$, Leon Battista. De re ædificatoria, trad. de G. Orlandi..., v. II, L. X, Cap. XVII, p. 998.

${ }^{91}$ CATANEO, Pietro. I quattro primi libri di architettura (Veneza, Figliuoli di Aldo, 1554), facsímile. Ridgewood: The Gregg Press Incorporated, 1964. L. II, Cap. XI, fls. 34v. 
92 VASARI, Giorgio. Le vite de'piu eccelenti pittori, scultori, e architettori, $3^{\mathrm{a}}$ ed. (rev. e ampliada pelo próprio autor). Florença: i Giunti, 1568. Parte I, p. 27 -A primeira edição do texto de Vasari é de 1550, quatro anos antes da publicação do texto de Cataneo. Como foi usada nesta investigação a terceira edição, não é possível se ter a certeza de qual dos dois autores seria a sugestão: Vasari já a citava na primeira edição do seu texto, ou resolveu incorporar a sugestão após ter lido o texto de Cataneo?

${ }_{93}$ MARTINI, Francesco di Giorgio. «Architettura civile e militare»..., v. III, t. II, tratado I, p. 317, nota 1 - Segundo Corrado Maltese, a pedra albazzana seria um calcário marnoso do qual era extraída cal hidráulica, ou cimento de pega rápida, exatamente pela presença de elementos argilosos em sua composição, daí servir para emprego em argamassa que ficasse em contato constante com a água.

${ }^{94}$ CATANEO, Pietro. I quattro primi libri di architettura..., L. II, Cap. XI, fls. 35. - [...] piglisi parti una di buona calcina albazzana, parti una di ghiarra sotile, parti una di buonissima rena [sic], \& in questi si piglia per i piu la rena di fiume molto bene lavata, aggiungnendovi [sic] polvere di Tevertino: perche lo fa migliore: \& messo che egli è in opera, non se gli da piu molestia.

${ }^{95}$ MARTINI, Francesco di Giorgio. «Architettura civile e militare»..., p. 115, nota 4 - Corrado Maltese, comentarista desse texto, informou que a staia (alqueire) era uma medida que variava muito a depender do local. Em Florença, correspondia a 24,4 litros.

${ }^{96}$ CATANEO, Pietro. I quattro primi libri di architettura..., L. II, Cap. XI, fls. 35. [...] piglisi per ogni due staia di calcina due altre staia di polvere di tegole, con mezzo staio di scaglia di ferro: \& s'intridino \& mescolino insieme con decottione di buccie di olmo, rimenandole spesso per quindici giorni; acciò che meglio venghino à imbeverarsi \& fare corpo insieme: \& smaltisi dipoi il pavimento, o qual se sia altra opera: \& si difreghi ogni giorno con morca di oglio, o lardo, con la mescola o cazzuola, sino a tanto, che se gli vegga sputare certa acquiccia bianca, \& alhora, senza piu toccarlo, si lassi in tutto seccare.

${ }^{97}$ PERONI,S. et al. «Lime based mortars for the repair of ancient masonry and possible substitutes", Mortars, cements and grouts used in the conservation of historic buildings. Roma: ICCROM, 1982, p. 63-99. p. 67 - [...] the addition of crushed ceramic bricks or tiles introduces definite hydraulic properties in lime mortars. Such mortars appear to be weaker than the pozzolanic ones but the amount of salts they may contain should be far smaller // [...] a adição de tijolos ou telhas moídos introduz propriedades hidráulicas definitivas em argamassas de cal. Tais argamassas aparentam ser mais fracas do que as pozolânicas, mas a quantidade de sais que elas podem conter deve ser muito menor.

${ }^{98}$ Tipos de vegetais.

${ }^{99}$ MARTINI, Francesco di Giorgio. «Architettura civile e militare»..., p. 116. - Anco pigliarai bucci d'olmo, fien greco, malva simita. Piglisi calcina di marmo staia due, solfo vivo quarti uno, polvar di pomice staia mezzo, gesso crudo messo al calore in nel dicozione, dal gesso infuore [...] E quando la calcina del marmo mancasse, la polvare d'esso o altra calcina a[d]operar si può;

100 MARTINI, Francesco di Giorgio. «Architettura civile e militare»..., t. I, p. 115/116. - Se alcuno stucco per serrare alcun pelo o cretto che in fonti, cisterne o in altre conserve fusse, piglisi vernice lequida, calcina viva, litargilio, polvare di solfo e mastice [...]

101 ZANINI, Gioseffe Viola. Della architettura, 2ª impr., Pádua, Giacomo Cadorino, 1677. L. I, Cap. XVI, p. 68.

102 Provavelmente um tensoativo, detergente que altera a polaridade das substâncias. 
${ }^{103}$ Calcário muito usado nas construções italianas.

${ }^{104}$ Conforme Zanini, a mistura destes dois ingredientes endureceria como pedra e seria denominada marogna.

${ }^{105}$ FÉLIBIEN, André. Des principes de l'architecture..., 1699. L. II, Cap. IV, p. 228.

${ }^{106}$ SCAMOZZI, Vicenzo. L'idea della architettura universale (Veneza, V. Scamozzi, 1615), fac-símile, Sala Bolognese, Arnaldo Forni, 1982. t. II, Parte II, L. VII, Cap. XX, p. 232.

${ }^{107}$ LIMA, Honório Fiel de. «Descrição dos trabalhos, que se executaram sob a direcção do Tenente General Bartholomeu da Costa para fundir em bronze de um jacto só a estátua equestre d'El Rei D. José 1. `», Boletim do Arquivo Histórico Militar, v. XLV, Lisboa, 1975. p. 203-360. p. 326 - No fundo da cova, entre o molde e as paredes, fez-se um massame com os tijolos, que tinham saído do recozimento, cimentados com uma composição de duas partes de gesso, e uma de barro queimado, que se tinha tirado do muro de recozimento, bem reduzido a pó [...]

${ }^{108}$ BLONDEL, Jacques-François, Cours d'architecture..., VII, t. V, de la maçonnerie, Cap. V, Art. VI, p. 197-207.

${ }^{109}$ D'AVILER, Augustin Charles. Cours d'architecture..., t. I, Parte I, p. 214. - II faut que le bon mortier soit composé de deux tiers de sable \& d'un tiers de chaux [...].

110 VASCONCELLOS, Ignacio da Piedade (Pe.), Artefactos symmetriacos, e geometricos..., L. IV, Cap. XVI, p. 378.

${ }_{111}$ ALBERTI, Leon Battista. De re ædificatoria, trad. de G. Orlandi..., v. I, L. III, Cap. IV, p. 188 - Catone dice che per ogni piede di lavoro si devono dare due moggi di rena e uno di calce. Altriautori danno proporzioni diverse. Vitruvio e Plinio dicono che la sabbia va mescolata alla calce in modo che questa sia un quarto se la sabbia è di cava e un terzo se è fluviale o marina.

112 SARAIVA, F. R. dos Santos. Novissimo diccionario latino-portuguez, [Rio de Janeiro], Garnier, s.d., p. 745 - Medida de capacidade para solidos e liquidos, = 8,64 litros; alqueire.

${ }^{113}$ CATON, M. Porcius. «L'économie rurale»..., t. I, Cap. XV, p. 38. - [...] il doit compter sur un modius de chaux, \& deux de sable par pieds de longueur de ces murs.

${ }^{114}$ FRIZOT, Michel. Mortiers et enduits peints antiques. Dijon: Université de Dijon, 1975. Publicação do Centro de Investigação sobre as técnicas Greco-romanas, n. ${ }^{\circ}$ 4, p. 40.

115 SAGREDO, Diego de. Medidas del romano (Toledo, 1549), fac-símile, introd. de Fernando Manás e Agustin Bustamante, Madrid, Instituto de Conservación y Restauración de Bienes Culturales, 1986 - O tratadista italiano Diego de Sagredo, por exemplo, concordou com Plínio no que diz respeito aos traços das argamassas.

${ }^{116}$ PLINIUS, C. Secundus, Natural history, Livros XXXVI-XXXVII..., v. X. Cap. XXIII, p. 139 There is quarry sand, to which has to be added one-quarter of its weight in lime; and river or alternatively sea sand, to which must be added one third.

${ }^{117}$ A depender da forma como os grãos se arrumam dentro de um determinado recipiente, podem ficar muitos espaços vazios entre os grãos, de modo que dois recipientes iguais podem, na prática, conter massas diferentes do mesmo sólido.

${ }^{118}$ PLOMMER, Hugh. Vitruvius and later Roman building manuals..., p. 37. 
119 Lembra-se que, com a inclusão de pedra britada, um agregado graúdo, o material passaria a ser considerado como um concreto. Quanto ao saibro poligonal, não há informações a seu respeito, mas supõe-se que também fosse um agregado graúdo.

${ }^{120} \mathrm{~A}$ necessidade de uma argamassa com maior ou menor fluidez era determinada, no entender de Alberti, pela pedra com que se trabalhava. Este é realmente um dos fatores determinantes, porém há outros, como o tipo de serviço a executar, a forma de aplicação do material e a velocidade de pega desejada.

${ }^{121}$ ALBERTI, Leon Battista. De re ædificatoria, trad. de G. Orlandi..., v. I, L. III, Cap. X, p. 214.

${ }^{122}$ Lembra-se que a orientação e intensidade dos ventos varia de uma região para outra, de modo que a sugestão dada pelo italiano não podia ser considerada como verdadeira para qualquer lugar.

${ }^{123}$ NEGREIROS, Jozé Manuel de Carvalho. Jornada pelo Tejo ..., fls. 39v.

${ }^{124}$ VELLOZO, Diogo da Sylveira. Architectura militar, Pernambuco, Cód. 49-III-3 (BAj), 1743. Parte II, Cap. XXIII, fls. [215].

${ }^{125}$ AZEVEDO FORTES, Manoel de. O engenheiro português..., t. II, L. VI, Cap. IV, p. 288 [...] que não usem a cal no traço, sem que este seja feito com duas partes de area, e huma de cal bem derregada [...].

${ }^{126}$ RODRIGUES, Maria João Madeira. SOUSA, Pedro Fialho de; BONIFÁCIO, Horácio Manuel Pereira. Vocabulário técnico e crítico de arquitectura..., p. 69.

${ }_{127}$ SÃO BENTO, Bernardo de (Frei). «Declaraçoens de obras», [Rio de Janeiro], 1684. fls. 29, SILVA-NIGRA, Clemente da (D.), Fr. Bernardo de São Bento..., p. 87.

128 SILVA-NIGRA, Clemente da (D.). Fr. Bernardo de São Bento ..., p. 119.

129 MOREIRA, Rafael. Um tratado português de arquitectura do século XVI, Lisboa, Faculdade de Ciências Sociais e Humanas, 1982. Dissertação de mestrado. p. 41 - No entender do professor Rafael Moreira, António Rodrigues deve ter dado tais informações com base em sua própria experiência profissional, visto que foi o principal arquiteto de Portugal por vinte e cinco anos.

${ }^{130}$ [RODRIGUES, António]. [Tratado de arquitectura], [Lisboa], Cód. 3675 (BNL), [séc. XVI]. Cap. VII, fls. 17v, MOREIRA, Rafael, Um tratado português de arquitectura do século XVI, Lisboa, Faculdade de Ciências Sociais e Humanas, 1982. Dissertação de mestrado. Parte II - [...] e se esta area com esta cal se ayumtar yumta e não se apartar h'ua da outra estara bem traçada, e não se ayu'tado bem hu'a com a outra sera nesesaryo deytar mais cal nos tres sestos de area. E deytãdo mais cal [...] he signal manyfesto que a [c]al que se fas de pedra que de sua natureza é seca não he tão boa [...] porque a cal pera ser boa quamto area menos ha houver mister tãoto sera mylhor. Observar que, ao indicar a mistura, o autor informou que deveria estar "bem traçada".

${ }^{131}$ Id., ibid., Cap. V, fls. 12v.

${ }^{132}$ DE L'ORME, Philibert. «Le premier tome de l'architecture» (Paris, Frederic Morel, 1567), Traités d'architecture, fac-símile. Paris: Léonce Laget, 1988. L. I, Cap. XVII, fls. 28 - Neste caso, o "cyment" era uma argamassa pozolânica, e não apenas o pó de telha ou tijolo, como aparecia com freqüência nos textos antigos.

${ }^{133}$ AZEVEDO FORTES, Manoel de. O engenheiro português..., t. II, L. VI, Cap. III, p. 282. 
${ }^{134}$ DUARTE, D. Livro dos conselhos de el-Rei D. Duarte (fls. 177 do livro da Cartuxa, Cap. [40]) Ca. 1430), compilação de João José A. Dias. Lisboa: Estampa, 1982. p. 165.

${ }_{135}$ PALLADIO, Andrea. I quattro libri dell'architettura (Veneza, Dominico de'Franceschi, 1570), fac-símile sob a responsabilidade de Ulrico Hoepli Editore Libraio, Milão, Hoepli, 1968. L. I, Cap. V, p. 8. - Per fare la malta si deve in questo modo com la sabbia mescolare; che pigliandosi arena di cava; si pongono tre parte di essa, \& una di calce: se di fiume ò di mare; due parte di arena, \& una di calce.

${ }^{136}$ MARTINI, Francesco di Giorgio. «Architettura civile e militare»..., v. III, t. II, tratado I, p. 317/318 - Informação dada para a confecção de argamassas hidráulicas, feitas a partir de pedra "albazzana" (grifo não existente no texto original). - La sua mistione com arena di fiume è: due parti arena et una calcina; com le altre, tre parte arena, et una calcina [...] Et «è» da intendere che universalmente ogni calcina mista com arena fluviale o marittima, se a quella sarà agionto la terza parte di testi pesti ovvero di antiqui tegoli, molto più tenace «che senza» diverrà. Quando per fare cisterne se avesse ad operare, la proporzione sua «alla arena» che ricerca è «questa»: «cioè» due parti calcina e cinque di aspera rena, cioè «subdupla sesquialtera».

${ }^{137}$ SARAIVA, F. R. dos Santos. Novissimo diccionario latino-portuguez..., p. 1139 e 1094, respectivamente.

${ }^{138}$ MARTINI, Francesco di Giorgio. «Architettura civile e militare»..., v. III, t. II, tratado I, nota 1, p. 318.

${ }^{139}$ COUTO, Mattheus do (o Velho). Tractado de architectura..., L. II, Cap. IX, p. 37.

${ }^{140}$ BRANCA, Giovanni. Manuale d'architettura, comentários e acréscimos de Giovanni Soli, $5^{a}$ ed., Modena, Soc. Tipografica, 1789. L. I, Cap. III, p. 7 - Mesma indicação de MARTINI, Francesco di Giorgio, «Architettura civile e militare»..., v. III, t. II, tratado I, p. 317.

${ }^{141}$ BRANCA, Juan. Manual de arquitectura, trad., comentários e acréscimos de D. Manuel Hijosa, [6 ${ }^{a}$ ed.]. Madrid: La viuda de D. Joachîn Ibarra, 1790. L. I, Cap. III, p. 8/9.

${ }_{142}$ FÉLIBIEN, André. Des principes de l'architecture..., 1699. L. I, Cap. XII, p. 34 - Segundo este autor, existiam cais [...] si gras \& si excellens qu'on en met cinq parties, \& mesme jusques à sept, contre une partie de chaux // [...] tão gorda e tão excelentes que colocamos cinco partes, e mesmo até sete, contra uma parte de cal.

${ }^{143}$ /d., ibid., L. II, Cap. VI, p. 46.

${ }^{144}$ PFEFFINGER. Fortificaçam moderna. Lisboa: Officina Real Deslandesiana, 1713. L. IV, Cap. XVII, p. 231.

${ }^{145}$ Pfeffinger indicou os traços 1:1 ou 1:3, enquanto que na maioria dos textos estudados encontrou-se 1:2 ou 1:3 (cal, areia), apesar de existirem variações.

146 [FREMIN]. Memoires critiques d'architecture..., p. 115 - [...] les architectes font, selon moy, des fautes, quand sans reflechir sur le sable qui se trouve dans les lieux où il convient de bâtir, ils disent dans leurs devis qu'il n'y a qu'à mettre deux tier de sable \& un tiers de chaux: ils en font encore une, quand indépendamment de cet examen, ils déterminent un sable sans au préalable l'avoir bien consideré.

${ }^{147}$ CATANEO, Pietro. I quattro primi libri di architettura..., L. II, Cap. IIII, fls. 29. - [...] non solo difficilmente si secca, ma per liquefarsi la salsedine, al tempo delle pioggie da se stessa ruina: il che, intermettendovi tempo, non avverrà cosi facile. 
${ }^{148}$ EÇA, Mathias A. R. da Silva de. Problema de architectura civil..., Parte II, Cap. XI, p. 160/ 161.

149 Agregados miúdos úmidos ocupam um maior volume do que quando secos, por causa do inchamento.

${ }^{150}$ Mesmo requerendo maior complexidade operacional na obra.

${ }^{151}$ GOMES, Adailton Oliveira; VALOIS, João Guilherme Cerqueira. «Argamassas com adição utilizadas na região metropolitana de Salvador», Revista da Jornada Profo Hernani Sobral, ed. única, Feira de Santana, 1994, p. 49-52. p. 50.

152 Valério de Oliveira foi batizado em Novembro de 1695 e ainda estava vivo em 1757.

${ }^{153}$ SCAMOZZI, Vincenzo, L'idea della architettura universale ..., t. II, Parte II, L. VII, Cap. XIX, p. 231. - [...] stemperando la calce à poco à poco con l'acqua [...] poi dopo bene rimenata à parte, à parte, vi si metti la sabbia, ò sia due tanti; o tre tanti della calcina, secondo che porterà la bonta dell'una, e dell'altra, e di nuovo si aggiungi, e si stemperi con l'acqua; perche certa cosa è, che ela diviene sempre migliori come la pasta del pane bene gramolato.

${ }^{154}$ [FREMIN]. Memoires critiques d'architecture..., p. 124. - Mais uma vez observou-se, pela indicação dada, que como a ciência ainda não sabia explicar determinados fenômenos químicos, alguns autores apelaram para justificativas transcendentais.

${ }^{155}$ Lembrar que, no caso da Mortier-Loriot, tinha-se que torná-la mais fluida para depois acrescentar cal virgem à mistura.

156 [CORMONTAIGNE]. Architecture militaire, Haia, Jean Neaulme et Adrien Moetjens, 1741. Parte I, Cap. IX, p. 86 e Parte I, Cap. XXII, p. 94.

${ }^{157}$ Se ficava firme, era boa; caso se destacasse da parede, era ruim.

${ }^{158}$ Método brasileiro de compressão diametral, desenvolvido pelo Eng. Lobo Carneiro.

${ }^{159}$ NBR-13528 - Revestimento de paredes e tetos de argamassa inorgânica - Método de ensaio. Rio de Janeiro: ABNT, 1995. 


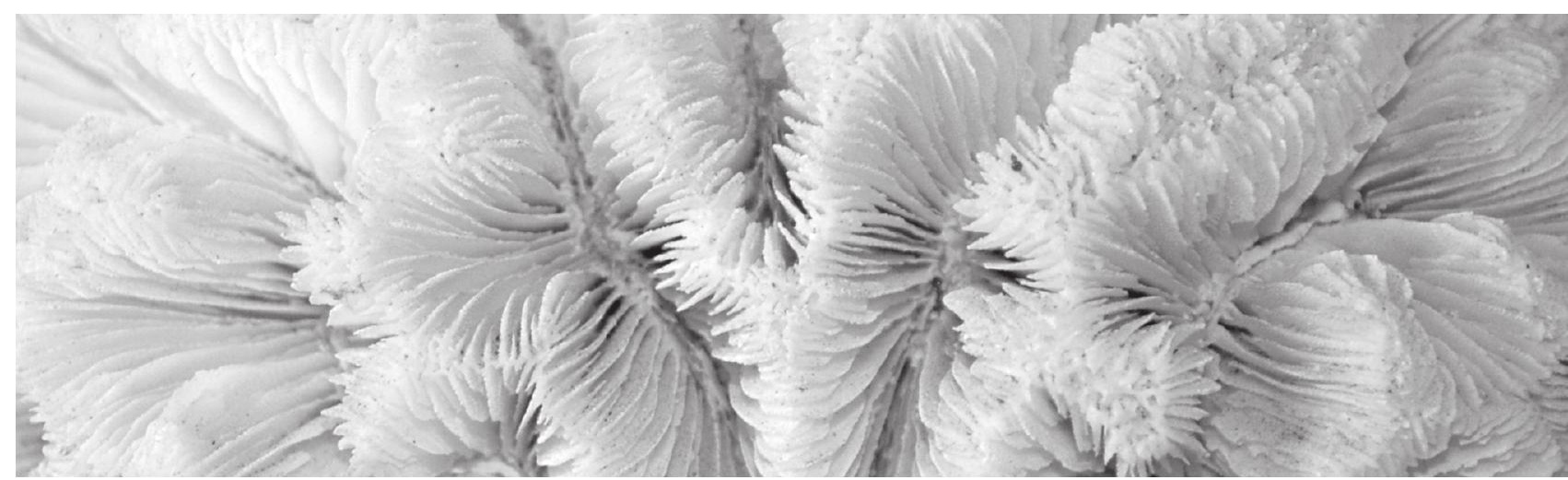

Cal 


\section{Noções genéricas}

Atualmente, o uso da cal diminuiu bastante, principalmente por causa da grande difusão do uso do cimento tipo Portland, porém até meados do século XIX, este era o aglomerante por excelência utilizado nas construções, tanto para assentamento, quanto para revestimento.

Scamozzi, por exemplo, considerava a cal como "o nervo e a força das construções", já que, sem ela, dizia ser impossível unir as diversas partes que as compunham ${ }^{1}$; no Diccionario de commercio e industria ${ }^{2}$, e em La science des ingenieurs, de Belidor ${ }^{3}$, textos do século XVIII, verificouse que a cal foi indicada, também, como a "alma" da construção.

Hoje, muitas são as tentativas feitas em diversas partes do mundo para recuperar a tecnologia perdida de trabalhar com a cal, principalmente para emprego em habitações de baixo custo, já que a produção mundial de cal volta-se, na maioria das vezes, para a agricultura, para a indústria (aciaria, indústria de tintas, de papel), para o tratamento de água, para degelo da neve (em substituição ao sal, em países de clima frio), dentre outros usos. No ramo da construção civil, a cal é ainda, com certa freqüência, usada em argamassas mistas com cimento, blocos de concreto celular ${ }^{4}$ e blocos de solo-cal.

No Brasil, assim como em outros países onde o déficit habitacional é elevado, uma atenção maior ao assunto seria válida, mas ao menos algo tem sido feito para a divulgação do produto, tanto que há uma associação nacional de produtores ${ }^{5}$, responsável por diversas publicações que abordam este tema, inclusive uma de expressão periódica, o Jornal Negócios da Calo. 
Apesar do emprego da cal ter caído em desuso no Brasil, ainda hoje pode ser constatado, em certas regiões mais inóspitas e de populações de baixa renda, o preparo artesanal do material. O município de Curaçá, no Sertão da Bahia, uma zona de solo calcário, é um exemplo. Naquela região, podem ainda ser observados fornos rudimentares, que são utilizados na fabricação da cal pelos moradores. Tais fornos, de planta circular, não apresentam cobertura, e o material submetido à queima é disposto em camadas alternadas com a lenha, o combustível utilizado. Neste mesmo município, algumas instituições têm tentado colaborar com os habitantes locais, instruindo-os como produzir, artesanalmente, um produto de boa qualidade ${ }^{7}$.

Em outros países, tentativas da retomada da cal como material de construção têm sido sentidas. Sediada no Reino Unido, a instituição Practical Action (Technology Challenging Poverty) ${ }^{8}$, por exemplo, tem agido no sentido de divulgar as vantagens do emprego da cal. Além da organização de seminários internacionais, publicação de livros e periódicos, o grupo financia investigações e envia consultores aos países do dito terceiro mundo, de modo a orientar a confecção do produto.

O conhecimento da cal é muito antigo. Este material já foi, pelo menos, datado desde o período Natufiano (10.300-8.500 a.C.) ${ }^{9}$, apesar de não se saber exatamente com que finalidade era utilizado. Como a cultura dos habitantes daquela época era ainda primitiva, o resíduo encontrado pelos arqueólogos pode ter sido oriundo de uma queima acidental, como, por exemplo, decorrente do emprego de pedras calcárias nas proximidades de algum fogo, e não como um remanescente da sua utilização na construção. De acordo com José Epitácio Guimarães, M. Venaut disse que a mais antiga aplicação deste aglomerante na construção civil data de 5.600 a.C. (na lugoslávia): uma laje de $25 \mathrm{~cm}$ de espessura ${ }^{10}$.

De qualquer modo, seu uso foi freqüente entre as antigas civilizações, como material construtivo, o que é comprovado através de vestígios arqueológicos e da bibliografia. O que variou, ao longo dos séculos, foi o processo de obtenção deste material, ou seja, a matéria-prima utilizada (calcários, mármores, corais, conchas de diversas espécies), os fornos e os combustíveis utilizados na calcinação, o método de calcinação em si (temperatura e tempo de queima), o manuseio e a extinção. 


\section{Matérias-primas tradicionalmente usadas}

\section{Rochas calcárias}

A primeira referência acerca da cal, encontrada na bibliografia consultada, em texto de arquitetura, foi descoberta no tratado de Vitrúvio. Todavia, ao procurar entender o que foi dito pelo mestre romano, chegouse à conclusão que é difícil a interpretação das informações dadas, a partir da análise de diversas edições do texto.

Fazendo-se, então, uma síntese do que foi dito nas oito edições consultadas, com base na terminologia empregada e tendo-se em vista os comentários ora feitos, as pedras para fazer cal seriam brancas, calhaus ou sílex de determinada região, rochas obviamente calcárias ${ }^{11}$.

Encontrou-se, em um texto atual sobre cal, a definição de uma cal hidráulica conhecida como cal romana, ou cimento romano, que seria uma cal virgem oriunda de calcários impuros contendo alto teor de sílica, componente que the daria propriedades cimentantes ${ }^{12}$. Seria este calcário o sílex mencionado? O termo poderia, também, ter sido usado simplesmente como sinônimo de seixo (confusões na tradução?), de modo que a definição dada para este material limitava-se a classificá-lo como uma rocha puramente quartzosa, donde se conclui que não seria adequada à fabricação da cal. Na realidade, segundo Cairoli Fulvio Giuliani, eram várias as rochas conhecidas antigamente por esta denominação ${ }^{13}$.

Levando-se em consideração apenas a questão da coloração das pedras, certos autores que sucederam Vitrúvio recomendaram variedades que não eram brancas. Martini, por exemplo, além de pedras de cor índigo ou cinza escuro, também foi favorável ao uso da pedra albazzana, citada pelo próprio Vitrúvio como pedra de cantaria, igualmente de cor de cinzas, para fazer cal hidráulica ${ }^{14}$.

Vários são os autores que falam na dureza e na coloração das pedras para fabricação da cal como fatores primordiais na dureza da argamassa. A título de exemplificação, citam-se a seguir algumas opiniões, por vezes um pouco distoantes da emitida por Vitrúvio. Destaca-se que, segundo Vitrúvio, seria melhor usar pedras compactas e duras para argamassas de assentamento, enquanto que pedras porosas seriam mais adequadas no caso de argamassa para revestimento ${ }^{15}$. 
Possivelmente, como a pedra dura era julgada capaz de propiciar a produção de uma cal de melhor qualidade, Vitrúvio deveria acreditar que resistiria mais ao carregamento. Já os rebocos, por sua vez, como não tinham como função receber cargas, mas simplesmente defendiam o imóvel contra as injúrias do tempo, podiam ser feitos com cal de pior qualidade, talvez também mais porosa.

Diogo da Sylveyra Vellozo afirmou que a melhor pedra para fazer cal era a de coloração cinza azulada ${ }^{16}$; Mathias Ayres e Negreiros recomendaram a pedra lioz ${ }^{17}$, rocha que apresenta variações de cores, sendo normalmente clara, porém não exatamente branca, e que sempre foi elogiada como capaz de produzir uma cal de muito boa qualidade.

J. F. Blondel também considerou que a dureza da cal dependia da dureza da pedra que a teria originado, sendo que as mais pesadas e as mais brancas seriam as mais adequadas no preparo de uma boa cal, consistindo o mármore na melhor opção. As pedras brandas só deviam ser usadas em caso de serem as únicas disponíveis ${ }^{18}$. Este último ponto é aquele no qual há discordância com o ensinamento de Vitrúvio, já que J. F. Blondel recomendou a pedra branda somente em última instância, o que aparentemente Vitrúvio não fez.

A crença no fato de que a dureza da pedra era responsável pela dureza da argamassa feita com sua cal permaneceu, mesmo tendo-se verificado, há algum tempo, através de análises e testes químicos e físicos, que isto não retratava a realidade ${ }^{19}$.

Segundo Cataneo, a natureza da cal variava conforme a natureza da pedra, sendo melhores as fabricadas a partir de pedras duras, provenientes de locais úmidos. Ainda na sua opinião, as cais oriundas de calcários de jazidas seriam melhores do que aquelas feitas a partir de seixos encontrados na superfície ${ }^{20}$. Isto provavelmente porque as rochas que se encontravam na superfície eram mais fracas, por serem mais alteradas.

Com relação à escolha da matéria-prima em vista da finalidade à qual se destinava a cal, Cataneo informou que, para cada uso - exterior, interior, lugares secos ou úmidos - era recomendada a calcinação de um tipo específico de pedra. Como um detalhe importante, esclareceu que, segundo Catão, os diversos tipos de pedra não deveriam ser misturados, pois o material resultante não apresentaria boa qualidade ${ }^{21}$. 
A mistura de rochas de diversas naturezas produz realmente um material mais heterogêneo e, conseqüentemente, de pior qualidade. Este é um cuidado que se deve ter até hoje, ao fazer-se cal. Quanto a se escolher a matéria-prima a depender da finalidade da cal, sabe-se, hoje, que a indicação não é procedente.

Philibert de l'Orme afirmou que a pedra calcária mais adequada à produção da cal era a mais pesada, e que soasse como um vaso de cerâmica bem cozido, quando recebesse leves pancadas ${ }^{22}$. Ou seja, deveria ser uma rocha dura, com densidade alta e com pouca porosidade, o que coincide com a opinião vitruviana, quando este autor mencionou o tipo de matéria-prima recomendado na fabricação de cal para argamassas de assentamento.

No tratado atribuído a Antônio Rodrigues, a pedra boa para fazer cal foi descrita como sendo aquela que era úmida (daí não poder ser retirada da superfície da terra) e capaz de receber lustro. Conforme a opinião do autor, a pedra seca não poderia receber lustro, pois, pelo fato de ter perdido a umidade por ação dos raios solares, teria também perdido a sua força, não servindo, por conseguinte, nem para receber lustro, nem para fazer cal. No seu entender, esta pedra poderia ser reconhecida, ao ser submetida ao processo de transformação em hidróxido ${ }^{23}$, pois queimava rapidamente, gastava pouca lenha, se desfazia com pouca água, e corria como azougue. Além disto, quando a cal era traçada com a areia, só funcionava satisfatoriamente com uma quantidade menor de areia do que aquela usada com pedra úmida, de boa qualidade, ou seja, havia na obra um consumo maior de cal, o que refletia um maior gasto ${ }^{24}$.

Scamozzi fez referência a diversos tipos de pedra para fazer cal, conforme a opinião de autores que o antecederam: pedras brancas variadas (algumas das quais semelhantes ao mármore); pedra fidenate ${ }^{25}$ (pálida ou tendente ao avermelhado); travertino; seixos porosos e leves; sílex ${ }^{26}$. Também citou um tipo de pedra existente em Praga, que apesar de ser negra como sílex ${ }^{27}$ e mais mole que este, após queima durante cinco dias e cinco noites propiciava a formação de uma cal branca ${ }^{28}$. Contudo, no seu texto encontrou-se informação explícita de que Andrea Palladio elogiou muito a cal feita de seixos duros e brancos ${ }^{29}$, com o que o próprio Scamozzi claramente concordou, completando dizendo que seria ótima principalmente se proveniente de pedras gordas e frescas, cuja cal teria capacidade de empastar muita areia ${ }^{30}$. 
Mattheus do Couto sugeriu também o uso da pedra mais dura para a fabricação da $\mathrm{cal}^{31}$, mas não mencionou que a pedra deveria ser obrigatoriamente branca. Curiosamente, referiu-se ainda a uma cal que, apesar de apresentar coloração escura ao sair do forno, clareava posteriormente e prestava-se à construção:

[...] esta cal he preta como cinza ao tirar do forno, mas feita em obra fica mais alva, mas não tanto como a da nossa pedra de lios ${ }^{32}$.

Leonardo de'Vegni, tradutor para o espanhol do texto de Giovanni Branca, foi igualmente partidário da opinião que as melhores pedras para se fazer a cal eram as mais duras, mas também não julgou que precisassem, necessariamente, ser brancas, já que apontou o "pedernal azulado obscuro" como adequado ${ }^{33}$.

Nota-se claramente, nos textos consultados, o desconhecimento a respeito da constituição mineralógica dos diversos componentes da crosta terrestre, sendo as pedras calcináveis identificadas pela experiência. Daí a grande dificuldade, em dias atuais, de saber-se a qual lítico os diversos autores se referiam. Scamozzi, entretanto, deu uma prova que realmente se sabia que determinado componente era o responsável por propiciar às pedras a capacidade de ser transformada em cal:

O calcário, que propriamente assim se chama por causa do cálcio de que se faz a cal $[\ldots]^{34}$.

Segundo E. Leduc, a primeira explicação científica acerca da decomposição dos calcários foi dada por Joseph Black (1728-1799), que mostrou que pela calcinação do carbonato havia liberação de gás carbônico ${ }^{35}$. As primeiras investigações experimentais sobre as argamassas de cal, no entanto, só foram feitas em 1818, por Louis Joseph Vicat ${ }^{36}$, o responsável pelo estabelecimento da fórmula para determinação do índice de hidraulicidade.

Quanto à distinção entre pedras que serviam para fazer cal daquelas que não tinham esta utilidade, alguns autores fizeram menção explícita à existência de tipos diversos. Teofrasto, por exemplo, ao falar sobre rochas, de maneira geral, disse o seguinte:

Alguns afirmam com certeza que todas as pedras irão derreter no fogo, exceto mármore, que pela queima é transformado em $\mathrm{cal}^{37}$. 
Não foi mencionado por Teofrasto o uso de outros calcários na fabricação da cal, mas como a Grécia é rica tanto em mármores quanto em calcários ${ }^{38}$, possivelmente estes estariam incluídos na definição genérica de mármore ${ }^{39}$, daí não serem citados textualmente. Por outro lado, quanto à informação que todas as pedras derretiam no fogo, só corresponderia obviamente à verdade, caso o autor estivesse se referindo a certos minerais, e não a pedras de construção.

Negreiros, pelo menos, especificou que a cal devia ser feita de pedras próprias a serem calcinadas, "porque nem de toda a pedra se pode fazer cal"40, o que é óbvio. Só as pedras carbonáticas - rochas que contêm carbonatos de cálcio, ou carbonatos de cálcio e magnésio ${ }^{41}$ - por ação do fogo, transformam-se em cal virgem, composto químico que, por sua vez, caso seja submetido à ação da água, origina a chamada cal extinta. Tanto a cal virgem, quanto a extinta - $\mathrm{CaO}$ e $\mathrm{Ca}(\mathrm{OH})_{2}$, respectivamente podem ser usadas na confecção de argamassa.

O próprio Negreiros completou a informação a respeito da formação da cal explicando que as pedras excessivamente rijas não podiam ser calcinadas; as muito brandas eram inúteis; as brandas que possuíam uma certa dureza produziam uma cal considerada inferior, que apresentava coloração parda. Ou seja, indicou, pela experiência, como avaliar a correlação entre os determinados tipos de rocha e a capacidade de serem convertidas em cal ou, eventualmente, como correlacionar a pedra com a qualidade da cal dela resultante.

Será que a coloração parda da cal mencionada por Negreiros não era decorrente do fato das pedras brandas escolhidas conterem impurezas? Como o seu texto não permite, hoje, uma identificação, com precisão, das pedras às quais fez referência, é impossível sair-se do nível de especulação. Sabe-se, entretanto, que as cais hidráulicas também apresentam esta coloração, resultante da presença de minerais argilosos em sua composição ${ }^{42}$, e são de boa qualidade.

Negreiros acreditava que a cal da pedra lioz, se extinta em água doce, seria a melhor cal do mundo ${ }^{43}$. Será que era porque a cal feita com tal tipo de rocha apresentava propriedades hidráulicas ${ }^{44}$ ?

Ao mencionar os estudos feitos com a cal de Alcântara, Castanheira das Neves informou: "[...] produziu por processos regulares pequenas porções da cal hydraulica, servindo-se para esse fabrico do calcareo 
marnoso subjacente ao calcareo compacto da pedreira do Alvito entre a de Raton e a do guano, proximo á ribeira de Alcântara". Entretanto, após caracterização feita em laboratório, ao menos em alguns tipos de lioz a hidraulicidade não foi constatada (anexos 3 e 4).

Ainda com relação à individualização, de maneira prática, dos líticos aptos ao preparo da cal, J. F. Blondel indicou verificar se a água forte ${ }^{45}$ agia sobre a dita pedra, causando efervescência ${ }^{46}$.

O método expedito usado atualmente para determinar se uma pedra é calcária é similar, porém utiliza-se ácido clorídrico $(\mathrm{HCl})$, e não ácido nítrico $\left(\mathrm{HNO}_{3}\right)$. Em ambos os casos, realmente ocorre a efervescência, pois há liberação de gás carbônico, indicativo da presença, ou não, de carbonato. O que pode ocorrer é que a reação seja mais intensa, no caso da presença unicamente de carbonato de cálcio, e de menor intensidade, quando existir uma mistura deste com carbonato de magnésio.

Por meio deste teste, entretanto, não é possível constatar se a pedra tem o teor de carbonatos de cálcio adequados à produção de uma cal de boa qualidade. Se um calcário for dolomítico, por exemplo, também ferve, ou seja, a pedra, reagindo com o ácido, também libera gás carbônico, causando efervescência, porém de menor intensidade. As cais feitas com calcários dolomíticos não têm qualidade tão boa quanto aquela feita com calcário composto unicamente por carbonato de cálcio ${ }^{47}$, de modo que o método de avaliação da rocha aconselhado por J. F. Blondel não era totalmente eficiente para esta finalidade.

Quanto aos mármores propriamente ditos usados na produção de cal, Michael Wingate (séc. XX) disse serem bastante procurados pelo seu teor de carbonatos. Porém apontou certos problemas: os que apresentam baixa porosidade são mais difíceis de calcinar, e certos tipos contêm impurezas, tais como olivina, que são muito cristalinas para reagir e fazer uma cal hidráulica48.

Alguns autores, a exemplo do espanhol Diego de Sagredo e de Philibert de l'Orme, ao mencionarem a fabricação da cal, disseram que o material produzido só atingiria a sua maior força, como aglomerante, se fosse feito com a mesma pedra a ser usada na construção do edifício ${ }^{49}$. $\mathrm{H}$. Bonnami afirmou ser isto geralmente impossível, assim como criticou o desconhecimento de cais hidráulicas naturais por parte dos antigos construtores $^{50}$. Disse que, se não eram cientes daquelas informações ${ }^{51}$, 
não poderiam ser comparados aos construtores seus contemporâneos. Deste modo, os romanos, na sua opinião, não tinham dado contribuição alguma à posteridade, em termos do uso de materiais de construção, ${ }^{52}$, o que é injusto. E que dizer de todo o legado de técnicas construtivas deixado pelos romanos, inclusive pontes e aquedutos?

A idéia de se fazer argamassa com a mesma pedra usada na cantaria do edifício tinha certa lógica: de maneira geral, quanto mais similares forem, em sua constituição, os materiais aplicados em contato, maior compatibilidade apresentam. Só que era realmente inviável fazer o indicado por Philibert de l'Orme. Além disto, argamassas feitas com cal de proveniência diversa das rochas usadas na mesma construção à qual ela se destinava foram sempre usadas e, tendo sido executadas dentro dos padrões recomendados, apresentaram comportamento muito bom. Muitos são os remanescentes arqueológicos que atestam isto.

No texto atribuído a Cormontaigne, recomendou-se que nas especificações fosse declarada a proveniência da cal. Deste modo, estaria assegurada, segundo o autor, a boa qualidade do material. A justificativa para assim se proceder foi que, como se tinha o conhecimento, por experiência, de muitas das matérias-primas utilizadas na fabricação deste material, sabendo-se de onde vinha, era possível ter-se uma idéia de como seria o seu comportamento ${ }^{53}$, o que era uma boa recomendação.

\section{Calcários marinhos}

Vitrúvio não mencionou, como matérias-primas para a produção da cal, os calcários marinhos (conchas, búzios e corais), citados por outros autores. Talvez isto tenha ocorrido porque era grande a quantidade de jazidas conhecidas de rochas de natureza carbonatada (mármores diversos, travertino, outras rochas calcárias), na época, no vasto Império Romano. Logo, a demanda podia ser atendida por estas fontes de matérias-primas, sendo, pois, dispensada a procura de fontes alternativas. Além do mais, sabe-se que os corais são típicos de águas tropicais, o que também pode ter concorrido para a omissão, ao menos, deste tipo de material, no texto vitruviano.

No início da colonização do Brasil, as jazidas de pedras carbonáticas ainda não haviam sido descobertas nas imediações da cidade de Salvador, mas os calcários de origem marinha eram abundantes, daí a sua utilização em larga escala. 
Como havia material alternativo, na Bahia, para o fabrico da cal (precisamente os corais, as cascas de ostras e as conchas, de maneira geral), não havia necessidade de se proceder o transporte de calcário (ou cal) a partir da Europa.

Nos documentos redigidos ao longo dos primeiros anos da fundação da cidade do Salvador ${ }^{54}$, pode-se notar que os portugueses tinham o conhecimento da produção da cal com cascas de ostras. Além disto, constatou-se que remeteram para o Brasil mestres caieiros, às custas da Coroa, de modo a auxiliarem na construção da cidade ${ }^{55}$.

Em uma das primeiras descrições minuciosas feitas do Brasil das quais se tem notícia, da autoria do cronista português Gabriel Soares de Sousa (1540-1592), também foi feita referência às ostras existentes na Bahia, cujas cascas podiam ser utilizadas na fabricação de cal para a construção ${ }^{56}$. Em outro capítulo, este autor abordou novamente o assunto, destacando a qualidade do material resultante:

A mor parte da cal que se faz na Baía é das cascas das ostras de que há tanta quantidade que se faz dela muita cal, a qual é alvíssima, e lisa também, e fazem-se dela guarnições de estuque mui alvas e primas $[\ldots]^{57}$

Apesar de Gabriel Soares considerar a cal feita a partir de cascas de ostras como de boa qualidade para a construção, pelo que foi dito no seu tratado, havia, também, no Brasil, em finais do século XVIII, cerca de duzentos anos depois, quem tivesse opinião diversa:

[...] apareceu em alguns sitioz pedra calcaria, que elles pizavão sem conhecer, mendigando a cal de casca de ostra, muito inferior á que agora tem $[\ldots]^{58}$

Será que, pelo fato da cidade de São Paulo, local ao qual a informação supra se refere, ficar no interior do país, a cal preparada com cascas de ostras era de pior qualidade por ser preparada no litoral e transportada sem estar devidamente acondicionada para o local, hidratando-se?

Quanto ao uso de calcários marinhos com a mesma finalidade, Gabriel Soares informou ainda que na llha de Itaparica ${ }^{59}$ havia três fornos, e fazia-se cal em quantidade: 
[...] qual cal é muito estranha porque se faz de umas pedras que se criam no mar no sítio desta ilha e em outras partes, as quais são muito crespas e artificiosas para outras curiosidades e não nascem em pedreiras mas acham-se soltas em muita quantidade. Estas pedras são sobre o leve por serem por dentro organizadas em alféolas ${ }^{60}$.

Este cronista complementou a informação dizendo que a cal feita com tais pedras apresentava como características as a seguir enunciadas, e propôs alternativas, caso não se tivesse a facilidade de encontrá-las, o que não julgou ocorrer:

[...] muito alva e liga a obra como dela se faz como a de Portugal e caldeiam-na da mesma maneira mas não leva tanta areia como a cal que se faz das ostras e de outro qualquer marisco, de que também se faz muito alva e boa e para todas as obras, quanto mais que, quando não houvera remédio tão fácil para se fazer infinidades de cal como o que está dito, com pouco trabalho se podia fazer muita cal porque na Baía, no rio de Jaguaripe e em outras partes há muita pedra lioz como a de Alcântara ${ }^{61}$ com umas veias vermelhas, a qual pedra é muito dura de que se fará muita obra prima, quanto mais cal para o que se tem experimentado já, e cozem muito bem e se não valem dela para fazerem cal, é porque acham estoutro remédio muito perto e muito fácil e para as mesmas obras e edifícios que forem necessários ${ }^{62}$.

A tradição que se tinha, na llha de Itaparica, até poucas décadas atrás, era a de utilizar, como matéria-prima para a produção de cal, corais do gênero Mussismilia (il. 2) ou cascalho de praia rico em exemplares de corais Meandrina braziliensis (il. 3), conchas e búzios, de modo que se crê que as pedras estranhas mencionadas por Gabriel Soares eram, na realidade, corais. O próprio Gabriel Soares escreveu que se achavam nas praias "limos esfarinhados de areia que está congelada e dura como pedra" ${ }^{63}$, material que, na realidade, consistia, possivelmente, em outro tipo de coral vulgarmente conhecido como rodolito ${ }^{64}$ (il. 4), e que também devia estar presente no cascalho usado, mais recentemente, na fabricação do cimento, o que era conveniente, dada a sua composição carbonática.

Chegou-se à conclusão que as pedras indicadas no texto quinhentista eram corais a partir de depoimentos dados por pessoas que conheceram o funcionamento da caieira da fazenda Parapatingas, naquela ilha, o que foi corroborado por indicações dadas por parentes de um antigo proprietário de uma outra caieira, também na mesma ilha. Isto sem falar que a tradição oral assim já contava. 
No texto da autoria de Frei Bernardo de São Bento foram também mencionadas as características de argamassas feitas com cal de cascas de ostras, assim como foi indicada a construção de caieiras para que se pudesse preparar uma boa cal. Isto comprova, além da utilização de cal desta proveniência, uma certa preocupação com a qualidade do material resultante, o que pode ser constatado através da leitura da citação a seguir:

\begin{abstract}
As paredes que nesta obra estaó para fazer, em q he nesesario, aja a mayor fortaleza, que puder ser [...] se devem obrar [...] tendo grande cuidado no modo de terçar a cal, que a quantidade do saibro, que se lhe botar, seia o q a bondade da cal puder sofrer; pois a que he feita de ostra sam, e limpa, poderá levar a quantia de saibro que se costuma; mas a que for de ostra podre, e çuja, nem presta nen pode sofrer o saibro de consideração, e faz fraca obra ${ }^{65}$.
\end{abstract}

Ainda hoje as conchas e cascas de ostras são usadas na fabricação de cal em países africanos e asiáticos ${ }^{66}$, e na Bahia (Brasil), após ter praticamente desaparecido a prática da utilização de matérias-primas de origem marinha no preparo de cal, até o ano de 1995 podia-se constatar o seu uso na produção de cimento, na indústria de Cimento Aratu ${ }^{67}$.

A bibliografia brasileira não menciona locais no país aonde ainda sejam usados corais ou conchas de animais marinhos na confecção de cal. Assim, não é possível avaliar as condições reais da sua produção. No entanto, sabe-se que, ao menos em pequenas vilas de pescadores no Recôncavo Baiano, essa prática ainda vigora, e o material é produzido artesanalmente, para consumo próprio. Barreiras do Jacuruna é uma delas.

No entanto, no final do século XIX, alguns ensaios para a verificação comparativa da resistência à compressão de cais de marisco e cais provenientes de determinado tipo de pedra foram feitos. O responsável pelos mesmos foi o engenheiro Ernesto Marcos Tygna da Cunha ${ }^{68}$ (anexo 2).

Segundo um técnico da TESIS (Tecnologia de Sistemas de Engenharia S/C Ltda), empresa auditora do Programa de Qualidade da Cal para a Construção Civil69 , não existe comprovação científica do emprego, nos dias de hoje, de calcários de origem marinha na indústria da cal no Brasil. Apenas pôde-se constatar que algumas marcas de cal, avaliadas compulsoriamente, apresentaram teores de óxidos muito baixos, constituindo-se em cais deterioradas. Isto poderia ser um indício do uso de material muito misturado. 


\section{Calcinação}

Catão ensinou que, para fazer cal a ser utilizada na agricultura, de modo a regular o $\mathrm{pH}$ ácido do terreno, devia-se cozer bem pedras calcárias de boa qualidade, de coloração o mais branca possível, e quanto menor a variação cromática das mesmas, melhor. Este autor também deu instruções de como fazer fornos de cal, e recomendou para se tomar cuidado com o fogo, de modo que não se extinguisse. Além disto, informou como saber, pela aparência, se as pedras estavam bem cozidas ${ }^{70}$.

No tratado da autoria de Alberti, encontrou-se a seguinte indicação sobre o material oriundo da queima de rochas calcárias:

Aquela cal que, apenas saída do forno, consiste em torrões não compactos, mas desfeitos e bastante pulverulentos, é reputada ruim e inadequada ao seu fim. Boa, por outro lado, é aquela que, purificada pelo fogo, torna-se alva, leve, sonora e que, banhada, produz crepitação intensa, levantando uma grande quantidade de vapor. À cal mencionada anteriormente, dada a sua escarsa energia, é bom misturar pouca areia; mais à segunda, que é mais forte ${ }^{71}$.

As indicações albertianas diziam respeito tanto aos resultados obtidos com a calcinação, de maneira geral, quanto aos fenômenos visíveis por ocasião do processo de extinção e à maneira prática de reconhecimento da qualidade do óxido formado. O material muito pulverulento mencionado aparentemente haveria sido queimado em excesso; a leveza indicaria provavelmente que o calcário tinha sido queimado no ponto certo. Ao mencionar a sonoridade da cal, Alberti talvez estivesse referindo-se a um material mais compacto, já que foi informado que a cal proveniente de óxidos desfeitos e bastante pulverulentos era ruim. Quanto à grande intensidade de vapor, decorrente da liberação de calor ao longo da transformação do óxido em hidróxido (reação exotérmica), denotava que a mudança estava realmente ocorrendo, e que o calcário não era dolomítico ou magnesiano, pois quando isto ocorre, a efervescência é menor.

Scamozzi descreveu os tipos de cal e de fornos que conhecia, e informou que a duração do processo de calcinação dependia não apenas da natureza da pedra, mas também da quantidade de material, do tipo de forno e da maneira como este foi arrumado por ocasião da queima, assim como do tipo de combustível utilizado, observações estas verdadeiras. 
Os indícios do término do processo de calcinação eram verificados, segundo o mesmo autor, através do ruído e da coloração do fogo, opinião também emitida por outros tratadistas.

Pela sua experiência, Scamozzi indicou que as pedras reduziam o peso, por ocasião da calcinação, em um terço, ou dois quintos do inicial ${ }^{72}$, e perdiam sua cor - o material resultante era mais branco do que a pedra que a havia originado - e cheiro originais, passando a ter odor e cor de cal. Scamozzi disse ainda que algumas pedras, por seu "caráter úmido", reduziam a força do fogo, e portanto não eram adequadas à fabricação da cal. Assim como também não o eram as serpentinas, as porfirinas, nem os seixos duríssimos, sendo mais resistentes do que o fogo, não permitindo o cozimento de pedras vizinhas ${ }^{73}$.

As serpentinas, as porfirinas e os seixos duros não podiam ser usados na fabricação da cal por não serem rochas de natureza carbonatada, e não por terem "caráter úmido", como informou Scamozzi.

Quanto à pedra perder a sua coloração e cheiro originais, e gerar um produto com cheiro e odor característicos, isto ocorre em decorrência da transformação sofrida pela matéria-prima.

Com relação ao preparo de cal de cascas de ostras, na Bahia, Gabriel Soares comentou que era um procedimento mais fácil e econômico do que se a matéria-prima fosse a pedra: gastava-se menor quantidade de lenha e em cerca de dez ou doze horas a cal viva estava pronta. Além disto, a cal assim preparada ficava tão boa que, ao ser hidratada, fervia em pulo como a cal de pedra que se costumava fazer em Lisboa ${ }^{74}$.

As cascas de ostra, por serem materiais de pouca espessura, são mais facilmente calcináveis do que pedras, ou mesmo corais. Logo, o processo de transformação do carbonato em óxido é realmente mais rápido do que aquele que se dá no caso do uso de pedras. No entanto, experimentou-se calcinar uma pequena quantidade de cascas de ostras em laboratório, a uma temperatura de $850^{\circ} \mathrm{C} \pm 5^{\circ} \mathrm{C}$. A temperatura de cozimento dos calcários varia entre $890^{\circ} \mathrm{C} \mathrm{e} 930^{\circ} \mathrm{C}$. A produção industrial, sendo mais lenta, exige uma temperatura, no máximo, igual a $890^{\circ} \mathrm{C}$. Os carbonatos de magnésio, entretanto, começam a se transformar a $720^{\circ} \mathrm{C}$. Como a tensão de vapor do gás carbônico é igual à pressão atmosférica (correspondente a $812^{\circ} \mathrm{C}$ de temperatura), valor inferior aos $890^{\circ} \mathrm{C}$ sugeridos, a queima industrial deve ser feita a uma temperatura 
intermediária entre estas duas, daí a adoção dos $850^{\circ} \mathrm{C}$, conforme indicação de Le Chatelier ${ }^{75}$.

Como a quantidade de matéria-prima disponível era pequena, estabeleceu-se, empiricamente, o tempo de queima em vinte horas, tendose constatado que era suficiente, em virtude exatamente da pequena quantidade e da pequena variação de temperatura $\left(850^{\circ} \mathrm{C} \pm 5^{\circ} \mathrm{C}\right)$.

As vinte horas não se mostraram excessivas, pois o calcário não ficou queimado, como pensava-se poderia ocorrer. Logo, pode-se inferir que, antigamente, muitas vezes a queima do material deve ter sido incompleta por não se prolongar o fogo por tempo suficiente. Hipótese facilmente comprovada, por exemplo, no caso da cal de corais: é muito comum encontrar-se fragmentos de material não calcinado em antigas argamassas (il. 5 e 6).

Um outro ponto digno de menção é que uma das razões para a cal "ferver em pulo" é por conter um alto teor de carbonatos de cálcio ${ }^{76}$. A hidratação dos óxidos de cálcio e de magnésio inicia-se ao mesmo tempo, porém a velocidade do processo no caso do óxido de cálcio é muito maior. Como o calor liberado ao longo da hidratação é alto, sendo maior no caso de cais cálcicas ${ }^{77}$, quando o material apresenta esta natureza, a água ferve. No caso de cais rápidas, então, o processo é prontamente visível.

Quanto à fabricação de cal a partir de calcários marinhos, Gabriel Soares afirmou que era efetuada em fornos, e o fogo a lenha, que era aceso por baixo de uma série de arcos, assim ficava por uma noite e um $\mathrm{dia}^{78}$.

Com relação ao funcionamento de caieiras artesanais na ilha de Itaparica, recolheu-se o depoimento de pessoas que chegaram a conhecêlas em funcionamento, há quase cinqüenta anos. Afirmaram que o combustível utilizado era a lenha, porém o tempo de queima era de três dias, findos os quais se procedia a extinção.

A divergência entre os tempos de queima mencionados deu-se possivelmente porque Gabriel Soares indicou que o material era calcinado em fornos, enquanto que, nas caieiras existentes no século $X X$, o material era simplesmente empilhado a céu aberto, alternando-se camadas de lenha e calcário. Nada mais lógico que a queima feita em um ambiente fechado se procedesse mais rapidamente do que ao ar livre, pois o calor não se dissipava com tanta facilidade. 
A respeito de pedras muito rijas, que não podiam ser calcinadas, Mathias Ayres deu algumas explicações, no que foi apoiado por Negreiros:

O diamante e outras pedras preciozas não se podem calcinar, por mais que o fogo seja violento, e diuturno. As partes de que a natureza as fabricou, são tão unidas e compactas entre sy, que os poros com que ficarão só dão passagem á materia subtil e etheria, mas não aos corpusculos do fogo; sendo que a calcinação, provem de uma certa desunião de partes, cauzada pela introdução violenta e successiva das particulas igneas, que entrão a occupar os poros ou intersticios do corpo que se calcina.

A pedra sexatil tão bem não se calcina, mas um fogo continuo e forte a vitrifica; sendo regra certa, que todo corpo que se vitrifica não se calcina; e o que se calcina não se vitrifica.

Outras pedras há, que sahem ja da terra vitrificadas; estas são totalmente inuteis, e o maior fogo não as pode reduzir a cal; porque a vitrificação he o ultimo periodo a que a natureza chega, como tão bem a arte; visto que depois de hum corpo estar vitrificado, ou seja naturalmente, ou arteficialmente, nesse termo permanece sempre sem admittir mudança ou sepparação alguma ${ }^{79}$.

As pedras preciosas, assim como as pedras que já saíam, no entender destes autores portugueses, vitrificadas da terra, realmente não se calcinavam por não serem rochas de natureza carbonatada. Ainda com relação à informação supra, acredita-se que a pedra sexatil fosse o quartzo, já que os cristais que compõem este tipo de pedra têm a forma sextavada e, quando submetidos a temperaturas elevadas durante um determinado período, podem se vitrificar. Segundo a explicação de Mathias Ayres, talvez tal pedra, se levada ao forno até a incandescência, sendo lançada em água fria, ficava com o mesmo aspecto anterior, porém recebendo pancada, partia-se ${ }^{80}$. Logo, é possível que realmente fosse quartzo, visto que este material só perde a estrutura cristalina caso permaneça sob temperatura elevada durante muito tempo, e para se transformar, efetivamente, em vidro, tem que estar combinado com outros compostos.

Em Jornada pelo Tejo, Negreiros apresentou uma ilustração de forno contínuo para cozimento da cal (il. 7), tendo fornecido uma descrição completa do seu funcionamento ${ }^{81}$. Este autor indicou igualmente o processo de enchimento recomendado para o forno e o seu rendimento diário, ou seja, a cal produzida com relação à quantidade de pedra utilizada ${ }^{82}$. Em sua opinião, um forno destes, que usava a lenha como 
combustível, poderia durar de quinze a dezoito meses, com uma produção diária de vinte moios de cal, ou seja, um pouco mais que 16.000 litros, de acordo com os valores indicados para esta antiga medida portuguesa, em Lisboa ${ }^{83}$.

$\mathrm{Na}$ descrição do forno e de seu funcionamento, pode-se notar especialmente as preocupações de Negreiros quanto à qualidade do material calcinado. Negreiros recomendou ainda que fossem recolocadas no dito forno as pedras que por ventura saíssem mal cozidas, e lembrou que o excesso de queima causava a extração da "substância da cal"84. Além do mais, este autor chamou a atenção para as desigualdades entre a cal formada de um mesmo tipo de rocha, mesmo se fosse toda cozida no mesmo forno, porém em fornadas diferentes ${ }^{85}$. Isto porque era impossível controlar as condições de queima, o que não acontece ao usar um forno tipo industrial ou mufla (em laboratório), como foi feito por ocasião da realização dos ensaios descritos nesse capítulo. Quanto a não se misturar diversos tipos de pedras, era correto o ensinamento, pois quanto mais heterogêneo um material, piores suas qualidades.

Para obter um material de boa qualidade, quando fosse necessária a utilização de vários fornos, simultaneamente, Negreiros indicou a execução de uma proteção ao seu redor ${ }^{86}$, o que ajudava na manutenção da temperatura.

Tal recomendação, que denota a preocupação do autor com a constância do fogo, era interessante, pois mantendo-se o fogo, na medida do possível, uniforme ao longo do tempo, o cozimento dava-se de maneira mais adequada. O vento, eventualmente, podia levar a uma redução da intensidade da chama, ou mesmo apagá-la, de modo que o material custaria mais a cozer, ou ficaria mal cozido. Logo, era uma indicação coerente, pois o material precisava ser integralmente calcinado, de modo que pudesse se transformar, pela extinção, em hidróxido.

De acordo com o descrito por Savary no Diccionario de commercio e industria, Vitrúvio, Andrea Palladio e arquiteto e tratadista italiano Giacomo Barozzi da Vignola haviam recomendado que o tamanho da pedra de cal a ser calcinada propiciasse a sua queima total em, no máximo, sessenta horas, ou seja, dois dias e meio ${ }^{87}$. Consultando-se tais textos, entretanto, verificou-se que nenhum desses autores deu este gênero de informação. Negreiros, por outro lado, recomendou que as pedras a cozer 
deveriam ser aproximadamente do tamanho de uma mão fechada ${ }^{88}$. Scamozzi, por sua vez, informou que o tempo de queima dependia de fatores diferentes ${ }^{89}$, e inclusive recomendou cinco dias e cinco noites para a queima de um determinado tipo de pedra negra ${ }^{90}$, o que perfaz cento e vinte horas, o dobro do tempo recomendado por Palladio e Vignola.

Como já foi comentado ao mencionar-se a calcinação de cascas de ostras, o tamanho do material a ser submetido à queima obviamente tem influência na duração do processo. Sendo assim, as pedras poderiam ser realmente partidas de modo a não apresentarem dimensões muito avantajadas ao serem introduzidas nos fornos. A prática em calcinar determinado tipo de rocha poderia servir para nortear os caieiros quanto às dimensões a serem adotadas. Quanto à indicação para que o processo de queima não durasse mais do que sessenta horas, foi informado anteriormente que na Bahia, até poucos anos atrás, procedia-se à queima em três dias, e o material funcionava satisfatoriamente.

J. F. Blondel, por sua vez, recomendou como combustível o uso de carvão mineral, ao invés de madeira. $\mathrm{O}$ argumento era que este tipo de carvão, além de propiciar uma queima mais rápida, produzia uma cal mais gorda e untuosa ${ }^{91}$.

Uma das possíveis explicações para esta indicação é que o carvão mineral desenvolve temperaturas mais altas do que a madeira ${ }^{92}$. Logo, consegue resultados mais rápidos. Quanto a produzir uma cal mais gorda e untuosa, a justificativa é descabida, pois estas características são intrínsecas do material.

\section{Extinção (hidratação)}

Plínio foi o autor que forneceu uma das receitas mais excêntricas de preparo da cal encontradas na bibliografia. Tal receita mais se assemelha a uma operação culinária do que a uma recomendação para o preparo de um material de construção: sugere que a cal deveria ser extinta em vinho, logo após a calcinação, e depois misturada com banha de porco e figos, que seriam agentes amaciantes. Curiosamente, depois de dar esta indicação, Plínio informou que a argamassa com ela fabricada endurecia mais do que uma pedra, mas que antes de ser utilizada fazia-se necessário que a superfície a recebê-la fosse completamente embebida em óleo ${ }^{93}$. 
Esta foi a única referência encontrada nos textos consultados acerca do uso do óleo como tratamento das superfícies a serem argamassadas. Não se chegou a testar o comportamento do material nestas condições, porém ao menos destaca-se que há dúvidas quanto à sua eficácia: acredita-se que o azeite, aplicado à superfície a receber a argamassa, dificultaria a sua aderência.

Plínio, ainda a respeito da extinção da cal, informou, assim como Vitrúvio, que devia ser um processo longo, de modo a alcançar-se o desejado amadurecimento:

Quanto mais velha a cal empastada, melhor. Por isto encontra-se nas leis de construção antigas que aqueles que forem construir usem cal de pelo menos três anos ${ }^{94}$.

Quando se fala neste período, previsto em lei, de três anos de espera, o que os autores antigos queriam dizer era que o material deveria ser submetido a um longo período de extinção. Isto com o objetivo de se assegurar intuitivamente que a transformação dos óxidos em hidróxidos havia sido completada, não havendo, por conseguinte, perigo em aplicar o material na parede e a extinção dar-se posteriormente, o que acarretaria no aparecimento de bolhas e fissuras em sua superfície. Pelo menos, com um longo período de extinção, a totalidade dos óxidos de magnésio também se transformaria em hidróxido ${ }^{95}$.

Uma passagem do tratado de Azevedo Fortes ratificou os ensinamentos feitos por Vitrúvio, Plínio e outros autores anteriores ao século XVIII, para que se propiciasse uma longa permanência da cal na água antes de ser usada. Sobre este assunto foi dito:

[...] melhor se for derregada em um tanque particular, e sempre cuberta com agoa por algum tempo: os antigos a deixavão nos tanques hum anno, e mais ${ }^{96}$.

A recomendação de Cataneo quanto à extinção da cal era que devia ser usada muita água, e que não fosse salgada. Na sua opinião, a água salgada era mais rica em sais do que a areia de praia. Logo, mais danosa97.

Possivelmente, a impressão que Cataneo tinha que a água do mar apresentava mais sais do que a areia era pelo fato dos mesmos estarem dissolvidos, e agirem mais rapidamente quando na mistura do que as partículas aderidas aos grãos de areia. O certo é que já se havia percebido 
que tanto a água do mar, quanto a areia marinha, eram agentes danosos ao material.

Nos comentários de Alberto Jacqueri Salles, tradutor do dicionário francês de Savary, que fez este trabalho por encomenda de Jacome Ratton, proprietário de caieiras nas imediações da antiga Lisboa ${ }^{98}$, verificou-se que havia uma crítica ao costume de utilizar-se a água salgada, porque:

[...] a qualidade salina não só faz com q' a cal não ligue bem, mas tambem faz humedecer as paredes conforme os tempos; e trabalha sempre na sua destruição, de sorte que como nunca se extingue, por fim destroe o edificio ${ }^{99}$.

O mencionado processo de umedecimento das paredes é a higroscopicidade, característica apresentada por certo sais, que atraem vapor d'água, trabalhando sempre na destruição da construção.

Francesco di Giorgio Martini mostrou-se favorável ao uso de muita água na extinção, por acreditar que se a água fosse colocada gradativamente, a cal não apresentaria boa qualidade. Na sua opinião, o material entraria novamente em efervescência, e não faria boa pega ${ }^{100}$.

Esta informação aparentemente não procede: se a cal entrava novamente em efervescência com a adição de mais água, como sugerido por Martini, é que o processo não havia se completado anteriormente. Logo, a segunda etapa de extinção seria até louvável, para prevenir problemas futuros na argamassa.

Quanto à ocasião adequada para se proceder a extinção, Philibert de l'Orme recomendou que fosse feita imediatamente após a calcinação ${ }^{101}$, e sob uma camada de calhaus e areia grossa de rio ${ }^{102}$. Isto porque 0 material, com o passar do tempo, endureceria como se fosse uma pedra. Philibert de l'Orme concordou ainda com a indicação de Vitrúvio que a melhor cal era feita da pedra mais dura, o que propiciava a formação de uma cal mais gorda e viscosa ${ }^{103}$.

É com base na constituição da cal que se determina se ela é gorda ${ }^{104}$, e não da dureza da pedra com a qual foi feita. Quanto a ser viscosa, realmente é uma característica das cais gordas.

Philibert de I'Orme disse igualmente que deveria ser observado o comportamento da cal durante a hidratação, de modo a verificar se, ao ser molhada, dela emanava um vapor espesso, e se aderia ao rabot ${ }^{105}$, instrumento utilizado a quando do seu preparo'06 (il. 8). 
Philibert de l'Orme devia pensar, assim como outros autores, que uma fumaça densa ao longo do processo de extinção fosse um indicativo de que o material estava reagindo integralmente com a água, o que realmente tem um certo sentido. Uma cal cálcica, rápida, realmente emite muitos vapores imediatamente após o aquecimento, ocasião em que o óxido está sendo transformado em hidróxido. Todavia, uma cal cálcica, lenta, apesar de demorar mais para começar a reagir com a água, também emite vapores durante a hidratação, embora em menor quantidade. Deste modo, após um período de tempo mais longo, mesmo com vapores de menor intensidade, o processo de extinção da cal vai se completar. Por outro lado, se o tempo estiver muito frio, o vapor formado por ocasião da extinção, também é muito espesso (il. 9).

Foi feita em laboratório uma avaliação do tempo de extinção de algumas cais preparadas com matérias-primas tradicionalmente usadas na construção: dois tipos de conchas (ostra ${ }^{107}$ e lambreta ${ }^{108}$ ), dois tipos de corais (Meandrina braziliensis e Mussismilia ${ }^{109}$ ) e dois tipos de pedras calcárias (mármore branco e pedra de lioz). Segundo a norma brasileira, o tempo total de extinção corresponde àquele decorrido entre a adição da água e a primeira de três leituras consecutivas que apresentarem variação inferior a $0,5^{\circ} \mathrm{C}^{110}$. Na prática, cada um dos ensaios foi dado por finalizado quando cinco das leituras efetuadas foram idênticas.

Apenas três das amostras ensaiadas consistiam em cais rápidas ${ }^{111}$. As cais obtidas a partir de cascas de ostras e de corais do gênero Mussismilia foram classificadas como médias e aquela obtida de corais do tipo Meandrina braziliensis, lenta.

Quanto à adesão da pasta ao rabot, denotava, conforme Philibert de I'Orme, que a cal, quando aplicada misturada com areia (ou seja, sob forma de argamassa), daria boa adesão à colher de pedreiro e à parede.

Um material que assim se comporta é tixotrópico, característica desejável para as argamassas, especialmente para aquelas destinadas a revestimento. Logo, a observação era pertinente.

Com relação ao longo período de extinção da cal, a opinião de Scamozzi foi a seguinte:

E falando das cais ainda banhadas e conservadas nas fossas, extinguem-se e desfazem-se, e maceram-se melhor, de modo que ficam mais bem feitas e são mais trabalháveis e de melhor pasta, e 
tem mais "nervo" e força, conseqüentemente dão melhor pega nos muros $^{112}$.

Scamozzi foi favorável ao umedecimento do óxido de cálcio logo após a queima, e concordou com outros autores que o material ficava imprestável rapidamente por causa da umidade do ar, ou por causa do frio. No entanto, chamou a atenção para não se colocar água em demasia, nem em quantidade menor do que o necessário, para que a cal não perdesse suas propriedades. Indicou, ainda, que era possível proceder a extinção de duas maneiras distintas: colocando simplesmente a água sobre o óxido, ou misturando-o, primeiro, com a areia.

Com relação à água a ser utilizada na extinção da cal, recomendou que fosse leve, limpa, fresca e clara ${ }^{113}$.

Na realidade, a água que apresenta excesso de matéria orgânica, principalmente em estado de decomposição, não é indicada no preparo de argamassas ${ }^{114}$. Também não devem estar presentes na água colóides em suspensão e sais acima da quantidade aceita como dentro dos padrões de potabilidade. Scamozzi recomendou ainda colocação da cal sempre sobre a água, para não queimar.

No já citado dicionário de Savary foram descritas duas formas distintas de se extinguir a cal, dependendo da finalidade à qual se destinasse: no caso de argamassas de assentamento ("para construir paredes"), a recomendação foi para que a água fosse lançada gradativamente sobre a cal em pedra, mas quando a finalidade era o revestimento ("para guarnecer"), a cal deveria ser colocada dentro de um recipiente contendo água doce em abundância ${ }^{115}$. Esta descrição assemelha-se à dada na atual norma brasileira quanto às formas de extinção, só que, neste último caso, a recomendação não se baseia no destino do produto final, mas sim no tipo de cal usada, se rápida, média ou lenta, ou seja, cais provenientes de calcários que entram em extinção em tempo inferior a cinco minutos, entre cinco e trinta minutos, e superior a trinta minutos, respectivamente ${ }^{116}$.

Não foi encontrada nos textos antigos consultados informação alguma acerca do tempo de extinção das cais, apenas que a cal viva deveria permanecer por dois ou três anos dentro da água, de modo a obter-se sua extinção completa. Sabe-se, atualmente, que o processo de 
extinção em si é rápido, mesmo nos casos de cais lentas, se comparado com esse longo período indicado nos textos antigos.

Segundo Giovanni Branca, o tempo de permanência na água era variável a depender do tipo de matéria-prima empregado. Informação correta: tanto que as cais, quanto à extinção, podem ser classificadas em rápidas, médias e lentas. Além disto, é sabido que um calcário carbonático reage mais rapidamente do que um dolomítico.

O padre Ignacio Vasconcellos, por sua vez, sugeriu que as "pedras de cal" fossem, aos poucos, borrifadas com água, até que se desfizessem completamente ${ }^{117}$, opinião que era partilhada por outros autores. Atualmente, dependendo do processo de extinção ser considerado como rápido, médio ou lento, indica-se que a água seja posta sobre a cal, ou que a cal seja posta sobre a água.

Não há diferença na qualidade do material resultante, utilizando-se os distintos meios de extinção. Tratava-se provavelmente de uma precaução para que, no caso de cais muito reativas, não ocorressem acidentes com os operários ao longo do processo.

O inglês John Ashurst (séc. XX) recomendou simplesmente, como forma de extinguir-se uma cal, que se colocasse água dentro de um tanque até atingir 300mm de profundidade, adicionando-se a cal viva com uma pá, devagar e cuidadosamente ${ }^{118}$, sem fazer restrições quanto ao tipo de material empregado (se cal rápida, média ou lenta).

Como Philibert de l'Orme e outros autores, Belidor ensinou que a extinção da cal devia ser feita sob a areia a ser usada na confecção da argamassa, banhando-as gradualmente até sua completa imersão na água.

Como a areia, de maneira geral, não tem participação no processo químico de formação da argamassa ${ }^{119}$, a vantagem que se observa em colocar a cal sob a areia por ocasião da extinção é a maior homogeneidade da mistura. No entanto, levanta-se a hipótese que este fato também contribuísse para que não acontecessem acidentes com os operários quando da manipulação do material, como já mencionado.

Ainda segundo Belidor, o traço da argamassa, em volume, devia ser 1:2, calculado com relação à cal viva. Mas, se a cal não fosse usada logo após a extinção, a quantidade requerida devia ser maior, variando, a depender da sua qualidade, em até $50 \%{ }^{120}$. 
Possivelmente, a recomendação foi dada por ser do seu conhecimento que a cal, após calcinada, tinha que ser muito bem armazenada para não absorver a umidade do ar, o que levaria à sua extinção. Se não fosse bem guardada, ela se extinguiria e, com o passar do tempo, estando umedecida e em contato com o gás carbônico presente na atmosfera, terminaria por se carbonatar antes de ser utilizada na argamassa. Ocorrendo isto, ficaria imprestável. Deste modo, no intuito de suprir falhas na argamassa, em decorrência de um eventual uso do material já carbonatado, é que esse autor teria recomendado o aumento da sua proporção na mistura.

Contudo, apesar de muitos autores recomendarem longos períodos de extinção, pode-se verificar que havia discordância a este respeito. Na realidade, o importante é que o material esteja seguramente bem hidratado. Pois se uma cal, sob a forma de hidróxido, contiver grânulos de cal viva, ao ser utilizada em argamassa de revestimento, fatalmente causará imperfeições na sua superfície: os grânulos, com a hidratação do material - o que pode ocorrer in loco através da absorção de vapor de água, ou por ação da umidade ascendente - tendem a se extinguir, aumentando de volume e formando bolhas, decorrentes do desenvolvimento de gás carbônico, o que pode levar à desagregação do revestimento. Quando a cal viva é extinta totalmente, na hora do preparo da argamassa, isto é evitado.

Com relação à extinção da cal com água salobra ou salgada, Negreiros sugeriu "prohibirse com penas e castigos rigorosos inalteravelmente executados"121 aqueles que assim procedessem. Isto porque a prática havia demonstrado que o sal era uma substância higroscópica e que, concluída a parede, atrairia para si vapor de água, o que causaria a sua desagregação por tensões de cristalização na porosidade dos constituintes da argamassa. Além do mais, o fato do sal atrair a si a umidade faria com que as paredes permanecessem eternamente úmidas, não adquirindo, por conseguinte, a compacidade e solidez almejadas. Negreiros também sabia que era impossível retirar o sal quando a parede estivesse pronta, caso ele tivesse sido inserido concomitantemente com a cal. A matéria-prima é que teria que ser isenta de sais. 
Atualmente, quando da constatação da existência de paredes que apresentam salinidade em sua constituição, o que se pode fazer, sem despender muitos recursos, é escarificar ao máximo as suas juntas, fazer um embrechamento utilizando cacos cerâmicos ou britas, e revesti-las com argamassas ditas "de sacrifício", ou seja, que teriam que ser substituídas com certa freqüência.

Mathias Ayres sugeriu uma forma de provar que o sal atraía a umidade para a parede ${ }^{122}$, mesmo que o processo não fosse visível. Negreiros concordou com a idéia, visto que transcreveu o que foi dito:

[...] tome-se a caliça daquella tal parede demolida em quantidade arbitraria, e posta em retorta chalibeada, esta se accomode em forno de reverbero, e applicado o recipiente, lotadas as juncturas, administrase hum fogo proporcionado, segundo a arte; e continuada a destillação, então se verà a porção de humidade em agoa vizivel e manifesta, que estava escondida no corpo da caliça ${ }^{123}$.

Conforme a indicação, o procedimento devia ser repetido após exposição do mesmo material ao ar, e sempre seria possível encontrar água no recipiente. Foi sugerido, ainda, que se fizesse o teste com caliça que não contivesse água salobra, para se perceber a diferença.

Nota-se, do acima exposto, que o espírito de experimentação era comum, no século XVIII, apesar de nem sempre as conclusões serem totalmente corretas. No caso supracitado, por exemplo, o resultado do teste não demonstrava apenas a higroscopicidade do cloreto de sódio, como Negreiros queria, mas também a umidade natural presente nos materiais, de maneira geral, adquirida em contato com o ambiente.

Ainda sobre a observação da atividade do sal, Mathias Ayres mencionou, sendo transcrito por Negreiros, que o surgimento da eflorescência salina - "levissima lanugem alviforme" - dava-se através da expulsão, por parte da parede, do sal nela presente, o que ocorria, em sua opinião, sempre que a extinção da cal fosse feita com água salgada' ${ }^{124}$.

É verdade que, nestas circunstâncias, as eflorescências sempre apareceriam, mas outras razões também poderiam concorrer para isso. $\mathrm{E}$ se o sal estivesse presente na areia usada na argamassa ou nos tijolos, ou mesmo se fosse adquirido através da capilaridade ascendente na parede já pronta? 
No Additamento: ao livro Jornada pelo Tejo, escrito cinco anos após Jornada pelo Tejo, Negreiros, por exemplo, sugeriu que o tijolo mal cozido ou a areia salgada poderiam também "pelar" a cal125.

A areia salgada poderia realmente ser responsável por "pelar" a cal, porém o tijolo mal cozido só causaria este problema se o solo com o qual tivesse sido feito contivesse sais.

No entanto, em Jornada pelo Tejo, o mesmo autor afirmou:

Esta objecção he pouco concludente, porque aquella materia sallina, e albicante, que ás vezes se manifesta na superficie das paredes, não he o sal que ella tem em si, mas outro mui diverso que o ar cria ${ }^{126}$.

Negreiros tentou justificar a origem do sal como sendo do ar, e não da água do mar, por ser, na sua concepção, nitroso. Sabe-se, hoje, que os nitritos e os nitratos são, na maioria dos casos, oriundos de matéria orgânica, podendo ser decorrentes de vazamentos de esgotos sanitários, de produtos usados para adubar o solo, ou eventualmente de materiais de construção contaminados por dejetos de natureza orgânica, enquanto que o aerossol marinho se constitui preponderantemente em cloreto de sódio. Pelo menos, através da observação feita, pode-se concluir que, naquele período, já havia uma preocupação com a identificação do material que se sabia nocivo às construções, embora não se tivesse conseguido até então estabelecer corretamente sua origem, nem sua constituição, em certos casos ${ }^{127}$.

Um outro cuidado recomendado por Negreiros (e compartilhado por outros autores), logo após concluída a calcinação, foi a pulverização da cal com água, pois se ficasse exposta ao ar:

[...] o ar Ihe dissipa todas as partes igneas que he a sua principal força, ficando a cal como huma terra branca e sem vigôr, em lugar que as pedras desfeitas com agoa, na forma que se pratica, rezulta huma cal forte, vigoroza, e com os requizitos necessarios para reedificar seguramente ${ }^{128}$.

O que ocorre quando o material fica exposto ao ar, após a calcinação, é a sua hidratação por causa do vapor de água, e posteriormente, sua carbonatação, por causa do gás carbônico presente no ar, de modo que não mais serve para ser utilizado na obra. De qualquer modo, o método sugerido por Negreiros só funcionaria se, imediatamente após a pulverização, toda a cal fosse molhada para se proceder a extinção. Caso 
contrário, o endurecimento do material seria ainda mais rápido do que se fosse deixado simplesmente a céu aberto.

Com relação ao tempo de armazenamento da cal em pasta, após extinção, também há diferenças, a depender do tipo de matéria-prima empregado: a cal feita a partir de pedra albazzana deveria ser usada não muito tempo após a adição da água à cal virgem, enquanto que as cais feitas com outras pedras duras (travertino, por exemplo), somente após um longo período de permanência na água (indicação vitruviana, como já visto), é que adquiririam condições adequadas de uso ${ }^{129}$. Provavelmente, o autor deu esta informação baseado no fato de que o óxido proveniente de pedra albazzana endurecia dentro da própria água da extinção, se ali permanecesse por muito tempo. A razão para isso seria a presença de componentes que the conferiam certa hidraulicidade.

As cais hidráulicas requerem longo contato água/cal, porém tomando-se precauções para não se ter água em excesso (10-15\% é geralmente suficiente). Isto para que os compostos silicatados e os aluminatos não sejam hidratados, endurecendo ${ }^{130}$.

Corrado Maltese, ao comentar o tratado de Francesco di Giorgio Martini, define pedra albazzana como "un calcare marmoso da cui si trae calce idraulica o cemento a presa rapida"131, daí servir para emprego em argamassa que ficava em contato constante com a água. Como era um material que continha componentes argilosos, não poderia ser branco. Esta é mais uma prova que nem sempre as pedras brancas são as melhores para a produção da cal.

Na realidade, se a cal apresenta componentes que the conferem uma certa hidraulicidade, seguramente vai ser recomendada para usos diferentes do que aquela que não os contém, por causa das suas propriedades. Possivelmente, por esta razão é que eram indicadas pedras diferentes para cada uso.

\section{Variação de massa e volume}

A capacidade da cal em combinar-se com a areia, secar e endurecer, formando uma argamassa, dependia, segundo Vitrúvio, da proporção dos quatro elementos presentes na rocha da qual havia sido originada. A influência destes elementos podia ser notada logo após o período de 
calcinação, pois a eles Vitrúvio atribuía a perda de um terço do peso sem alteração de volume da pedra ${ }^{132}$.

Cataneo concordou com a variação de peso indicada por Vitrúvio ${ }^{133}$. Scamozzi, por outro lado, informou que esta redução, por ocasião da calcinação, equivaleria a um terço, ou dois quintos do peso inicial, como comentado anteriormente.

No já citado manuscrito atribuído a Antônio Rodrigues, encontrouse a descrição de um teste prático para se saber se o material estava cozido. Tal teste consistia exatamente na verificação do que Vitrúvio dizia: pesava-se uma pedra antes de acender o forno, e tornava-se a pesá-la quando se suspeitasse que já estava cozida, fato que seria comprovado quando a pedra apresentasse uma redução de massa em, pelo menos, um terço ${ }^{134}$.

Esta variação de massa foi verificada em laboratório, constatandose, para o caso das matérias-primas estudadas (cascas de ostras, cascas de lambretas, corais, pedra lioz e mármore branco), que houve redução de cerca de $44 \%$ do valor inicial, em cinco, dos seis materiais estudados. A massa do mármore reduziu cerca de $47 \%$, porque era dolomítico.

Provavelmente os fatores que levaram outrora à constatação da redução do peso em apenas 33\%, conforme relato na bibliografia pesquisada, foram a falta de controle da temperatura de queima e a eventual presença de impurezas nas matérias-primas utilizadas. Como nos testes realizados em laboratório a temperatura foi controlada, obtevese uma calcinação de maior parte do material, o que pode ser verificado através dos dados anteriormente indicados.

Ao fazer-se o cálculo da variação de peso molecular em decorrência da transformação do calcário (carbonato) em cal viva (óxido), pode-se verificar que a perda total teórica é de $44 \%$, o que confere, de maneira aproximada, com os valores encontrados ${ }^{135}$ :

$$
\mathrm{CaCO}_{3}+\text { calor } \rightarrow \mathrm{CaO}+\mathrm{CO}_{2} \uparrow
$$

A perda verificada no peso molecular, comparando-se o carbonato (100 u.m.a.) com o óxido de cálcio (56 u.m.a.), corresponde exatamente a 44 u.m.a., que é equivalente à quantidade de gás carbônico produzido e liberado na reação. 
No caso de uma cal dolomítica ${ }^{136}$, entretanto, o cálculo estequiométrico indica que a perda de peso molecular é correspondente a 47,8\%, conforme explicitado a seguir ${ }^{137}$ :

$$
\mathrm{CaCO}_{3} \cdot \mathrm{MgCO}_{3}+\text { calor } \rightarrow \mathrm{CaO}+\mathrm{MgO}+2 \mathrm{CO}_{2} \uparrow
$$

Comparando-se o peso molecular da dolomita (184 u.m.a.) com a soma dos pesos moleculares dos óxidos resultantes (96 u.m.a.), a perda é de 88 u.m.a., correspondente ao gás carbônico liberado.

Lembra-se que não há alteração de massa por ocasião da hidratação do material, o que pode ser constatado por meio da verificação dos pesos moleculares entre os constituintes presentes, nas equações que regem o processo:

$$
\mathrm{CaO}+\mathrm{H}_{2} \mathrm{O} \rightarrow \mathrm{Ca}(\mathrm{OH})_{2} \text { ou } \mathrm{CaO}+\mathrm{MgO}+2 \mathrm{H}_{2} \mathrm{O} \rightarrow \mathrm{Ca}(\mathrm{OH})_{2}+\mathrm{Mg}(\mathrm{OH})_{2}
$$

De maneira geral, os autores consultados concordaram com Vitrúvio e Cataneo ao mencionarem a redução de volume após a calcinação. No entanto, alguns comentaram, ainda, que o material aumentava de volume, o que ocorria após a extinção. Giovanni Branca foi um deles. Para este autor, uma boa cal era viscosa, tenaz, requeria muita água durante o processo de extinção, aumentava muito de volume e apresentava boa consistência ${ }^{138}$.

O aumento de volume do material, comentado por Giovanni Branca e por outros tratadistas, é visível quando da adição gradual da água sobre a cal virgem, especialmente no caso de cais de extinção rápida. Não poderia corresponder a um aumento de volume entre a cal viva, pulverizada, e a cal extinta, pois basicamente a cal era usada sob a forma de óxido ${ }^{139}$ ou de pasta, o que inviabilizava qualquer avaliação entre os volumes do material calcinado e do hidróxido obtido.

As reações de calcinação e hidratação propiciam uma redução e um aumento, respectivamente, na massa do material. O carbonato de cálcio, por exemplo, perde cerca de $44 \%$ da sua massa, enquanto que o óxido ganha $32 \%$, quando completamente hidratado, valores estes ligeiramente variáveis a depender do grau de pureza da rocha ${ }^{140}$. 


\section{Caracterização das matérias-primas e das cais}

Para efeito de caracterização das cais estudadas em laboratório, foram identificados, por meio de espectroscopia de emissão atômica por plasma indutivamente acoplado (ICP-AES) (il. 10), diversos elementos (Anexos $3 \mathrm{e}$ 4). A partir dos valores encontrados para cada um deles, foram calculados os percentuais dos óxidos importantes na determinação de propriedades do material.

A determinação da presença de estrôncio e bário foi feita no intuito de verificar se algum destes elementos poderia vir a servir para caracterização das matérias-primas usadas ou das cais preparadas. Concluiu-se, por exemplo, que a identificação do óxido de bário não serve para este fim, visto que em todos os tipos de cais estudado tal óxido apresenta-se em quantidades muito ínfimas. No entanto, ao verificar-se os teores de óxido de estrôncio presentes nas diversas amostras, constatase que as cais provenientes de corais talvez possam ser identificadas através desse elemento, pois os valores obtidos foram muito superiores aos demais. Para se ter a certeza que uma cal teria sido feita da queima de corais, no entanto, um maior número de ensaios teria que ser feito, avaliando-se, inclusive, outros tipos de corais.

Por outro lado, concluiu-se que não é possível, simplesmente com base nesta mesma análise, assegurar qual o tipo de coral usado na fabricação de uma determinada cal. Isto seria, inclusive, difícil, no caso de ter sido empregue uma matéria-prima composta por uma mistura de materiais diferentes, como o cascalho da llha de Itaparica, ao qual já foi feita alusão.

Constatou-se ainda que:

- No caso da cal feita a partir de cascas de lambretas, o percentual de sílica encontrado foi maior do que aquele presente nas demais cais preparadas em laboratório ${ }^{141}$. É possível que o material contivesse areia como impureza, o que, segundo J. W. Herath, é comum em cais de corais e conchas ${ }^{142}$.

- O fato dos percentuais dos óxidos de silício, de ferro e de alumínio terem sido mais elevados nas amostras oriundas de pedra lioz, pode 
indicar a presença de minerais argilosos. Isto poderia ser verificado através de ensaios de difratometria de raios- $X$.

- O alto percentual de óxido de magnésio encontrado nas amostras de mármore (matéria-prima e cal) é indicativo de que o mármore era dolomítico.

\section{Índice de hidraulicidade}

O índice de hidraulicidade é determinado através da correlação entre os percentuais de determinados óxidos presentes nas argamassas. Apesar desta correlação somente ter sido estabelecida pelo engenheiro francês Louis Joseph Vicat, no século XIX, optou-se por verificá-la, no âmbito da presente investigação. Tomou-se tal decisão pelo fato de terem, por vezes, sido mencionadas, em textos do século XVIII ou de séculos anteriores, cais que endureciam dentro da água, ou seja, cais hidráulicas. As que endureciam ao ar eram as cais aéreas. A título de ilustração, destaca-se que foi encontrado, na Biblioteca da Ajuda, em Lisboa, um manuscrito recriminando o uso de cal feita com conchas em obras aquáticas ${ }^{143}$.

Avaliou-se, em laboratório, cais feitas com cascas de ostras e de lambretas (il. 11 e 12), constatando-se que as cais feitas com tais conchas não eram hidráulicas, mas o número de ensaios efetuados não foi suficiente para se ter condições de generalizar que toda e qualquer cal feita a partir de conchas é aérea.

Quanto à determinação do índice de hidraulicidade, a bibliografia brasileira atual apresenta uma pequena divergência na sua fórmula: alguns autores consideram apenas a relação entre os percentuais de sílica, alumina e óxido de ferro e o percentual de óxido de cálcio; enquanto que outros também incluem na fórmula os percentuais de óxido de magnésio presentes na amostra. As duas fórmulas mencionadas para cálculo do índice de hidraulicidade (i) são, pois:

- Conforme o engenheiro brasileiro Eládio Petrucci ${ }^{144}$ (séc. XX):

$$
\mathrm{i}=\frac{\% \mathrm{SiO}_{2}+\% \mathrm{Fe}_{2} \mathrm{O}_{3}+\% \mathrm{Al}_{2} \mathrm{O}_{3}}{\% \mathrm{CaO}}
$$


- Conforme o também engenheiro brasileiro José Epitácio Guimarães ${ }^{145}$ :

$$
\mathrm{i}=\frac{\% \mathrm{SiO}_{2}+\% \mathrm{Fe}_{2} \mathrm{O}_{3}+\% \mathrm{Al}_{2} \mathrm{O}_{3}}{\% \mathrm{CaO}+\% \mathrm{MgO}}
$$

Julga-se mais conveniente esta última possibilidade, pois muitos dos calcários utilizados na fabricação da cal, de maneira geral, são dolomíticos. Assim sendo, tal fórmula é que foi adotada para os cálculos dos índices dos materiais ensaiados.

Com relação à classificação das cais conforme o seu índice de hidraulicidade, encontrou-se, igualmente, sutis diferenças entre os dois autores. A indicação de cada um deles é apresentada a seguir:

- Para José Epitácio Guimarães ${ }^{146}$, as cais podem ser classificadas em:

Fracamente hidráulica: $0,10<\mathrm{i}<0,16$

Moderadamente hidráulica: 0,16 $<\mathrm{i}<0,40$

Eminentemente hidráulica: $0,40<\mathrm{i}<0,50$

- Eládio Petrucci ${ }^{147}$, ao invés de considerar a existência da categoria das moderadamente hidráulicas mencionada por José Epitácio Guimarães, distribuiu os valores desta faixa nos seguintes grupos: medianamente hidráulicas $(0,16<\mathrm{i}<0,30)$ e francamente hidráulicas $(0,30<\mathrm{i}<0,40)$, mantendo os mesmos valores nos casos de cais fracamente hidráulica e eminentemente hidráulica.

.J. Paz Branco ${ }^{148}$, autor português do século XX, ratificou as indicações de Vicat, que são um pouco diversas das duas anteriormente citadas:

Gorda ou magra: $0,0<\mathrm{i}<0,10$

Debilmente hidráulica: $0,10<\mathrm{i}<0,16$

Medianamente hidráulica: $0,16<\mathrm{i}<0,31$

Hidráulica padrão: 0,31<i<0,42

Eminentemente hidráulica: 0,42 $<\mathrm{i}<0,50$ 
Para aferir o grau de hidraulicidade das cais, existe ainda outro índice, o índice de cimentação (IC), também calculado com base nos percentuais presentes dos mesmos óxidos ${ }^{149}$. Só que são usados alguns fatores de correção, conforme pode ser constatado através da análise da fórmula:

$$
\mathrm{IC}=\frac{2,8 \% \mathrm{SiO}_{2}+0,7 \% \mathrm{Fe}_{2} \mathrm{O}_{3}+1,1 \% \mathrm{Al}_{2} \mathrm{O}_{3}}{\% \mathrm{CaO}+1,4 \% \mathrm{MgO}}
$$

De acordo com este índice, as cais podem ser classificadas nas mesmas categorias previstas anteriormente:

Fracamente hidráulica: $0,30<\mathrm{i}<0,50$

Moderadamente hidráulica: 0,50 $<\mathrm{i}<0,70$

Eminentemente hidráulica: $0,70<\mathrm{i}<1,10$

Com base nos ensaios, todas as cais produzidas no NTPR foram classificadas como aéreas ${ }^{150}$.

\section{Notas}

${ }^{1}$ SCAMOZZI, Vincenzo. L'idea della architettura universale (Veneza, V. Scamozzi, 1615), fac-símile, Sala Bolognese, Arnaldo Forni, 1982. t. II, Parte II, L. VII, Cap. XIX, p. 230.

2 SAVARY. Diccionario de commercio e industria. Trad. de A. Jacqueri Salles, [Lisboa], Cód. MEPAT, anterior a 1813. v. I, verbete cal, p. 353-357. p. 354.

${ }^{3}$ BELIDOR, Bernard Forest de. La science des ingenieurs. Paris: Claude Jombert, 1729. L. III, Cap. III, p. 7.

${ }^{4}$ GUIMARÃES, José Epitácio Passos. A cal. São Paulo: Pini, 1997. p. 120 - Blocos formados pela mistura de cal, areia e pó de alumínio metálico.

${ }^{5}$ ABPC - Associação Brasileira dos Produtores de Cal.

${ }^{6}$ Esta publicação quadrimestral da ABPC, editada em São Paulo e distribuída para todo o Brasil, fornece informações sobre o setor minero-industrial da cal, não apenas a nível nacional, mas também mundial.

${ }^{7}$ GNADLINGER, João. Redescobrindo a cal para construir cisternas. Juazeiro: Fonte Viva, [1999].

${ }^{8}$ Anteriormente denominado Intermediate Technology Development Group (ITDG).

9 KINGERY, W. David, VANDIVER, Pamela, PRICKETT, Marta, «The beginnings of pyrotechnology. Part Il», Journal of field archaeology, 1988, v. XV, p. 219-243. p. 219.

${ }^{10}$ GUIMARÃES, José Epitácio Passos. A cal..., p. 21.

${ }^{11}$ VITRUVIO POLLIO, Marco. I dieci libri dell'architettura, trad. e comentários de Daniel Barbaro, Veneza, Francesco Marcolini, 1556. L. II, Cap. V, p. 47. - [...] a cal "cozida", seja 
de pedra branca, ou de selice. / VITRUVE. Les dix livres d'architecture. Correção, tradução e notas de Claude Perrault (Paris: Jean Baptiste Coignard, 1684), fac-símile, Bruxelas, Pierre Mardaga, 1979. L. II, Cap. V, p. 36. - [...] que ela seja feita com pedras brancas, ou "cailloux". / VITRUVIO POLIÓN, Los diez libros de arquitectura, trad. de Joseph Ortíz y Sanz (Madrid, Imprenta Real, 1787), fac-símile com prólogo de Defín Rodríguez Ruiz, [Madrid], Akal, 1992. L. II, Cap. V, p. 35. - [...] fazendo-a de pedra branca ou de "sílex". / VITRUVIUS, The ten books on architecture, trad. de Morris Hicky Morgan, Nova lorque, Dover Publications, 1960 (reimpressão da edição publicada em Cambridge pela Harvard University Press, em 1914). L. II, Cap. V, p. 45. - [...] devemos ser cuidadosos para que seja queimada de uma pedra que, se macia ou dura, seja em todo caso branca. / VITRUVIO, Marco Lucio, Los diez libros de arquitectura, tradução, prólogo e notas de Agustín Blánquez, Barcelona, Iberia, 1955. L. II, Cap. V, p. 43. - [...] esta, para que seja boa, terá que ser feita de pedra branca ou de pedra dura. / VITRUVIUS, On architecture, trad. de Frank Granger, versão bilingüe latim/inglês, Cambridge/Londres, Harvard University Press/William Heinemann, 1962. v. I, L. II, Cap. V, p. 97/96. [...] para queimá-la de pedra branca ou lava. / VITRUVIO POLIÓN, Marco Lucio, Los diez libros de arquitectura, introdução de Defín Rodríguez Ruiz, trad. de José Luis Oliver Domingo, Madrid, Alianza, 1995. L. II, Cap. V, p. 107. [...] pedra branca ou sílex. / VITRÚVIO, Os dez livros de arquitectura, trad. de Helena Rua, Lisboa, IST, 1998. L. II, Cap. V, p. 36.

12 GUIMARÃES, José Epitácio Passos. A cal.... p. 267.

${ }^{13}$ GIULIANI, Cairoli Fulvio. L'edilizia nell'Antichità, 4ª impressão, Roma: NIS, 1995. Cap. VII, p. 149 - [...] la selce, il marmo, la pietra di monte e simili, tutte quelle globalmente individuate nell'antichità con il termine «silex» // [...] o calhau, o mármore, a pedra de montanha e similares, todas aquelas globalmente conhecidas na antiguidade com o termo «sílex».

${ }^{14}$ MARTINI, Francesco di Giorgio. «Architettura civile e militare»... v. III, t. II, tratado I, p. 317.

${ }^{15}$ VITRUVIO, Marco Lucio. Los diez libros de arquitectura, tradução de Agustín Blánquez.... L. II, Cap. V, p. 43.

${ }^{16}$ VELLOZO, Diogo da Sylveyra, Architectura militar. Pernambuco, Cód. 49-III-3 (BAj), 1743. Parte II, Cap. XXV, fls. 222v.

${ }^{17}$ EÇA, Mathias Ayres Ramos da Sylva de. Problema de architectura civil. Lisboa: Antonio Rodrigues Galhardo, 1777. Parte I, Cap. VIII, p. 156 // NEGREIROS, Jozé Manuel de Carvalho. Jornada pelo Tejo, [Lisboa], Cód. 80 (AHM), 1792. fls. 143.

${ }^{18}$ BLONDEL, Jacques-François. Cours d'architecture. Paris: Desaint, 1777. v. VII, t. V, De la maçonnerie, Cap. V, Art. I, p. 179-180.

${ }^{19}$ McKEE, Harley. «Commentary, masonry and masonry products: mortar, plaster/stucco and concrete», Preservation and conservation: principles and practices. Anais da The North American International Conference of Williamsburg. Washington: The Preservation Press, 1976. p. 204-205.

${ }^{20}$ CATANEO, Pietro. I primi quattro libri di architettura (Veneza, Figliuoli di Aldo, 1554), facsímile. Ridgewood: The Gregg Press Incorporated, 1964. L. II, Cap. V, fls. 29v.

${ }^{21}$ /d., loc. cit.

22 DE L'ORME, Philibert. Le premier tome de l'architecture (Paris: Frederic Morel, 1567), Traités d'architecture, fac-símile, apresentação de J. M. Pérouse de Montclos. Paris: Léonce Laget, 1988. L. I, Cap. XVI, fls. 27v/28. 
${ }^{23}$ Reação de calcinação seguida por extinção.

24 [RODRIGUES, António], [Tratado de arquitectura], [Lisboa], Cód. 3675 (BNL), [séc. XVI]. Cap. VII, fls. 17-18v. MOREIRA, Rafael. Um tratado português de arquitectura do século XVI. Lisboa, Faculdade de Ciências Sociais e Humanas, 1982. Dissertação de mestrado - A semelhança atribuída pelo autor da cal com o mercúrio metálico (azougue) serve para dar uma idéia da consistência do material.

${ }^{25}$ Tufo calcário amarelo-amarronzado, conforme informação do geólogo italiano Lorenzo Lazzarini.

${ }^{26}$ SCAMOZZI, Vincenzo, L'idea della architettura universale..., t. II. Parte II, L. VII, Cap. XVII, p. 223.

${ }^{27}$ Destaca-se que nem todo sílex é negro.

${ }^{28}$ SCAMOZZI, Vincenzo, L'idea della architettura universale..., t. II Parte II, L. VII, Cap. XVIII, p. 227 - Não se conseguiu descobrir exatamente que pedra era a de Praga, porém, a título de curiosidade, submeteu-se à queima, em laboratório, uma amostra de mármore preto, constatando-se que a cal viva formada apresentou coloração branca.

${ }^{29} /$ d., ibid., t. II, Parte II, L. VII, Cap. XVII, p. 223 - Nesta indicação percebe-se que alguns autores consideravam que a pedra tinha que ser dura e branca, e não, opcionalmente, de um tipo, ou de outro.

${ }^{30} /$ d., ibid.t.II, Parte II, L. VII, Cap. XIX, p. 230.

${ }^{31}$ COUTO, Mattheus do (o Velho). Tractado de architectura, [Lisboa], 1631. Cód. F.7752 (BNL). Cap. IX, p. 37 - A cal será melhor aquella q' de mais rija pedra se fizer, e a q' de mais branda peor.

32 Id., ibid.. Cap. IX, p. 38.

${ }^{33}$ BRANCA, Juan, Manual de arquitectura, trad. comentários e acréscimos de D. Manuel Hijosa, [6ª ed.]. Madrid: La Viuda de D. Joachîn Ibarra, 1790. L. I, Cap. III, p. 8, nota 1.

${ }^{34}$ SCAMOZZI, Vincenzo, L'idea della architettura universale..., t. II. Parte II, L. VII, Cap. XVIII, p. 227. - La calcare, che propriamente così se chiamano dalla voce del calcolo di che sì fà la calcina $[\ldots]$

${ }^{35}$ LEDUC, E.. Chaux et ciments, $2^{\mathrm{a}}$ ed.. Paris: J. B. Baillière et fils, 1919. Cap. VII, p. 14.

${ }^{36}$ LE CHATELIER, H., Recherches éxperimentales sur la constitution des mortiers hydrauliques. Paris: Ve Ch. Dunod, 1904. p. 36.

${ }^{37}$ THEOPHRASTUS, History of stones, trad. de Sir John Hill, Londres, 1774. p. 47, prop. XX - Grifos do autor. - Some absolutely affirm, that all stones will melt in the fire except marble, which by burning is reduced to lime.

${ }^{38}$ MARTIN, Roland. Manuel d'architecture grecque. Paris: Picard et Cie, 1965. v. I, p. 128.

${ }^{39}$ Toda pedra capaz de receber polimento.

40 NEGREIROS, Jozé Manuel de Carvalho. Jornada pelo Tejo..., fls. 142v.

${ }^{41}$ A cal pode ser calcária, magnesiana ou dolomítica, a depender dos percentuais de óxido de magnésio presentes.

${ }^{42}$ GUIMARÃES, José Epitácio Passos. A cal..., p. 90/91 - A cor varia de creme a marrom escuro. 
${ }^{43}$ NEGREIROS, Jozé Manuel de Carvalho. Jornada pelo Tejo..., fls. 143.

${ }^{44}$ CASTANHEIRA DAS NEVES, J. da P., «Estudo sobre algumas caes hydraulicas e magnesianas nacionaes», Revista de Obras Públicas e Minas. Lisboa, t. XXIII, Jul./Set. 1892, n. ${ }^{\circ} 271$ a 273. p. 207-304. Parte I, p. 212.

${ }^{45}$ Ácido nítrico diluído.

${ }^{46}$ BLONDEL, Jacques-François. Cours d'architecture..., v. VII, t. V, De la maçonnerie, Cap. V, Art. I, p. 180.

${ }^{47}$ GUIMARÃES, José Epitácio Passos, A cal..., p. 75 a 79 - Apenas 10 a 25\% do óxido de magnésio sob a forma hidratada está presente nas cais dolomíticas ou magnesianas extintas à pressão atmosférica. Logo, características como plasticidade, capacidade de retenção de água e incorporação de areia, são afetadas neste tipo de material. Como solução, atualmente costuma-se utilizar a hidratação deste tipo de cal sob pressão.

${ }^{48}$ WINGATE, Michael, Small-scale lime-burning, Londres, ITP, 1985. Cap. III, p. 24.

49 DE L'ORME, Philibert, Le premier tome de l'architecture..., L. I, Cap. XVI, fls. 28 // SAGREDO, Diego de, Medidas del romano (Toledo, 1549), fac-símile, introd. de Fernando Manás e Agustin Bustamante, Madrid, Instituto de Conservación y Restauración de Bienes Culturales, 1986.

${ }^{50}$ Só sabiam fazer, segundo Bonnami, argamassas com características similares através da adição de pó cerâmico.

${ }^{51}$ Bonnami exemplificou comentando que o desconhecimento das cais hidráulicas não permitia a execução de blocos a serem utilizados dentro do mar.

52 BONNAMI, H., Fabrication et controle des chaux hydrauliques et des ciments. Paris: Gauthiers-Villars et fils, 1888. p. 5.

${ }_{53}^{5}$ [CORMONTAIGNE], Architecture militaire, Haia, Jean Neaulme et Adrien Moetjens, 1741. Parte I, Cap. IX, p. 86 e Parte I, Cap. XXII, p. 94.

${ }^{54}$ A cidade foi fundada em 1549, seguindo desenho enviado de Portugal.

${ }^{55}$ ANTT, Papéis do Brasil, avulsos 3, n. ${ }^{\circ}$ 6. Doc. de 13/8/1551.

${ }^{56}$ SOUSA, Gabriel Soares de, Noticia do Brazil (Mss., 1587), transcr. em português atual de Maria da Graça Pericão. Lisboa: Alfa, 1989. Parte II, Cap. CXL, p. 208 - [...] há tantas ostras na Baía e em outras partes que se carregam barcos delas muito grandes para fazerem a cal das cascas de que se faz muita e muito boa para as obras, a qual é muito alva e há engenhos que se gastou nas obras deles mais de três mil moios de cal destas ostras, as quais são muito mais sadias do que as de Espanha.

${ }^{57}$ Id., ibid., Parte II, Cap. CLXXXVIII, p. 252.

${ }^{58} \mathrm{AHU}, \mathrm{CA}, \mathrm{SP}, \mathrm{Cx} .44$, n. ${ }^{\circ} 44,10 /$ Ago/1798. Of. de António Manuel de Melo Castro e Mendonça para $D$. Rodrigo de Sousa Coutinho - António Manoel era governador e capitãogeral da capitania de São Paulo.

${ }_{59}$ ANDRADE, Rodrigo M. F. Artistas coloniais. Rio de Janeiro: MEC, 1958. p. 9. Apud SIMAS FILHO, Américo, A propósito de Luís Dias, Salvador, FGM, 1998. p. 26 - O primeiro local, na Bahia, onde se começou a fazer cal foi exatamente na llha de Itaparica, conforme referência feita pelo mestre Luís Dias em sua carta de 15/8/1551: [...] Pero de Carvalhaes e Francisco Gomes haviam descoberto cal e pedra na ilha de Itaparica, o que Ihes valeu a 
mercê de $4 \$ 000$ a cada um, concedida por Tomé de Souza. Este foi um fato importante, pois facultou o início da construção de pedra e cal.

${ }^{60}$ SOUSA, Gabriel Soares de. Noticia do Brazil..., Parte II, Cap. CLXXXVIII, p. 252.

${ }^{61}$ Quanto a existirem rochas idênticas ao lioz de Alcântara, no rio Jaguaripe, na Bahia, esta informação não confere com a realidade. Contudo, em Carnaíba, também na Bahia porém a cerca de $650 \mathrm{~km}$ do local indicado, há um calcário que apresenta certa semelhança com o português.

62 /d., ibid., Parte II, Cap. CLXXXVIII, p. 252 e 253.

${ }^{63} / d$., ibid., Parte II, Cap. CLXXXVII, p. 252.

${ }^{64}$ Concreções de algas Corallinaceae, do gênero Mesophyllum, segundo a geóloga Viviane Testa.

${ }^{65}$ SÃO BENTO, Bernardo de (Frei), «Declaraçoens de obras», [Rio de Janeiro], 1684. fls. 29, SILVA-NIGRA, Clemente da (D.), Fr. Bernardo de São Bento. Salvador: Tipografia Beneditina, 1950. p. 87 - Na nota de pé de página n. 91 de Silva-Nigra, há ainda a seguinte informação: "A fim de obter cal boa, Frei Bernardo de São Bento, mandou instalar uma caieira na ilha de São Gregório (situada na foz do rio Inhomerim, no interior da Guanabara) com grande proveito para as obras do mosteiro. Dietário, do Rio, Mss., ps. 26 e 235)".

${ }^{66}$ HILL, Neville, HOLMES, Stafford, MATHER, David (ed.), Lime and other alternative cements, Exeter, Intermediate Technology Publications, 1992.

${ }^{67}$ Segundo informação de um antigo funcionário da fábrica, Eng. Antonio Barreto Dórea, a matéria-prima utilizada na produção do cimento era oriunda de bancos de corais decompostos, apresentando granulometria, genericamente falando, de conchas até areia. Tais reservas teriam sido descobertas por antigos saveiros, que as coletavam para uso no fabrico de cal. Os ensaios realizados no material naquela fábrica apresentaram como resultado uma dosagem superior a $80 \%$ de carbonatos totais, sílica inferior a $1 \%$ e magnésio inferior a $1,5 \%$.

${ }^{68}$ REBOUÇAS, André. Guia para os alumnos da $1^{a}$ cadeira do $1^{\circ}$ anno de engenharia civil. Rio de Janeiro: Typographia Nacional, 1885. p. 72.

${ }^{69}$ Programa criado pela ABPC para avaliar a qualidade do material produzido e consumido no Brasil.

${ }^{70}$ CATON, M. Porcius. L'economie rurale, DE LA BONNETRIE, M. Saboureux, traduction d'ancien ouvrages latins relatifs a l'agriculture et a la médecine vétérinaire. Paris: P. Fr. Didot, le Jeune, 1771. p. 70 - O autor estava certo ao indicar que quanto mais uniforme fosse a coloração da rocha, melhor a cal seria: a uniformidade na coloração significa uma maior homogeneidade mineralógica da rocha, que por sua vez implica em uma maior homogeneidade das suas propriedades.

${ }^{71}$ ALBERTI, Leon Battista. De re ædificatoria (Florença, 1495), trad. de Giovanni Orlandi, introd. e notas de P. Portoghesi, ed. bilingüe latim/italiano, L'archittetura, Milão, II Polifilo, 1966. v. I, p.186 e 188. - Quella calce che, appena uscita della fornace, consiste di zolle non compatte, ma sfatte e assai polverose, è reputata non buona e insufficiente al suo fine. Buona invece è quella che, purificata dal fuoco, risulta biancheggiante, leggera, sonora, e che, bagnata, produce intenso crepitio sollevando una grande quantità di vapore. Alla calce menzionata prima, data la sua scarsa energia, è bene dare poca rena; di più invece alla seconda, che è più forte. 
${ }^{72}$ Em termos percentuais, este último valor corresponde a 40\%, já se aproximando mais da realidade, conforme demonstram os cálculos estequiométricos.

${ }^{73}$ SCAMOZZI, Vincenzo. L'idea della architettura universale..., t. II, Parte II, L. VII, Cap. XVIII, p. 228.

${ }^{74}$ SOUSA, Gabriel Soares de. Noticia do Brazil.., Parte II, Cap. CLXXXVIII, p. 252.

75 LE CHATELIER, H.. Recherches éxperimentales sur la constitution des mortiers hydrauliques..., p. 31 e 34.

${ }^{76}$ Outras razões poderiam ser, por exemplo, a porosidade do material e sua superfície específica.

${ }^{77}$ GUIMARÃES, José Epitácio Passos. A cal..., p. 72. - A temperatura de 2,3 litros de água pode subir de $12^{\circ} \mathrm{C}$ para $100^{\circ} \mathrm{C}$, quando extinta uma grande quantidade do material.

${ }^{78}$ SOUSA, Gabriel Soares de. Noticia do Brazil..., Parte II, Cap. CLXXXVIII, p. 252 - Esta pedra [calcário marinho] se enforna em fornos de arco como os em que cozem a louça, com a sua abóbada fechada por cima da mesma pedra, mas sobre os arcos. Está o forno todo cheio de pedra e o fogo mete-se-lhe por baixo dos arcos com lenha grossa e cozem uma noite e um dia e coze muito bem [...].

${ }^{79}$ EÇA, Mathias Ayres Ramos da Sylva de. Problema de architectura civil..., Parte I, Cap. VIII, p. 150 e 151 // NEGREIROS, Jozé Manuel de Carvalho. Jornada pelo Tejo..., fls. 142V e 143 .

${ }^{80}$ EÇA, Mathias Ayres Ramos da Sylva de. Problema de architectura civil..., Parte I, Cap. VIII, p. 154 e 155.

81 llustração praticamente idêntica consta em outro texto do mesmo autor, Additamento: ao livro Jornada pelo Tejo, [Lisboa], 1797. Cód. 3760 (BNL). v. III.

82 NEGREIROS, Jozé Manuel de Carvalho. Jornada pelo Tejo..., fls. 47 a 49.

${ }^{83}$ DOURSTHER, Horace. Dictionnaire universel des poids et mesures anciens et modernes, Bruxelas, s.n., 1840. Apud SANTOS, Vitor Manuel V. Lopes dos. O sistema construtivo pombalino em Lisboa em edifícios urbanos agrupados de habitação colectiva, Lisboa, Fac. de Arquitectura da Universidade Técnica de Lisboa, 1994. Tese de doutorado. v. II, anexo AM, p. 87. - O "moyo", ou "moio", é uma antiga medida portuguesa de volume de sólidos. Em Lisboa, na segunda metade do século XVIII, esta medida correspondia a 811,2 litros,

${ }^{84}$ NEGREIROS, Jozé Manuel de Carvalho. Jornada pelo Tejo..., fls. 143v.

${ }^{85}$ /d., ibid., fls. 100.

${ }^{86} / d$., ibid., fls. 50v - [...] um telheiro em roda tapado com taboado, para impedir o vento, por quanto embarassa o laborar o fogo, com igualdade, e resulta o prejuízo de não ficar tão geralmen ${ }^{\text {te }}$ cozida.

${ }^{87}$ SAVARY, Diccionario de commercio e industria..., v. I, verbete cal, p. 355.

${ }^{88}$ NEGREIROS, Jozé Manuel de Carvalho. Jornada pelo Tejo ..., fls. 47.

${ }^{89}$ SCAMOZZI, Vincenzo, L'idea della architettura universale ..., t. II, Parte II, L. VII, Cap. XVIII, p. 228 - [...] secondo la forma della fornace, e la forza del foco, e la quantità, e qualità delle pietre, e l'ordine nel quale elle sono state poste la dentro [...] // [...] segundo a forma da fornalha e a força do fogo, e a quantidade e qualidade das pedras, e a ordem em que são postas lá dentro [...] 
${ }^{90}$ /d., ibid., t. II, Parte II, L. VII, Cap. XVIII, p. 227.

${ }^{91}$ BLONDEL, Jacques-François. Cours d'architecture..., v. VII, t. V, De la maçonnerie, Cap. V, Art. I, p. 180.

${ }^{92}$ BOUILLET, M. N.. Dictionnaire universel des sciences, des lettres et des arts, $12^{\mathrm{a}}$ ed. Paris: Hachette et Cie, 1877. Verbete "houille", p. 834.

${ }^{93}$ PLINIUS, C. Secundus. Natural history, Livros XXXVI-XXXVII, publicação bilingüe sob a resp. de D. E. Eichholz. Londres: Oxford, 1962. v. X. p. 143 - Maltha is the most adhesive of substances and grows harder than stone. Anything that is treated with it is first thoroughly rubbed with olive oil. - Argamassa é a mais adesiva das substâncias e fica mais dura do que pedra. Qualquer coisa que for tratada com ela deve ser primeiramente completamente untada com azeite de oliva.

${ }^{94}$ PLINIO (o Antigo). Historia naturale, trad. de Ludovico Domenichi, Veneza, G. Ferrari, 1561/1568. L. XXXVI, Cap. XVIII, p. 1150. - La calcina intrisa quanto è piu vecchia, tanto è migliore. Onde si trova nelle leggi delle case antiche, que quegli che tolgono a murare, non usino calcina che non sia almeno di tre anni.

${ }^{95}$ Em situação normal, a extinção do óxido de magnésio é mais lenta do que a do óxido de cálcio.

${ }^{96}$ AZEVEDO FORTES, Manoel de. O engenheiro português (Lisboa, Manoel Fernandes da Costa, 1729), fac-símile. Lisboa: Direcção da Arma de Artilharia, 1993. t. II, L. VI, Cap. IV, p. 288.

${ }^{97}$ CATANEO, Pietro. I primi quattro libri di architettura..., L. II, Cap. V, fls. 30 - [...] per causa della salsedine è dãnata la rena marina, tanto maggiormente per la medesima ragione si debbe fuggire l'acqua salsa, per partecipare molto piu della salsedine, che la rena // [...] por causa do sal é estragada a areia marinha, e basicamente pela mesma razão se deve fugir da água salgada, por ser muito mais salgada do que a areia.

${ }^{98}$ Em Alcântara, zona atualmente dentro do perímetro urbano.

99 SAVARY. Diccionario de commercio e industria..., v. I, verbete cal, p. 355-356.

100 MARTINI, Francesco di Giorgio. «Architettura antica e moderna»..., v. II. t. I, p. 105.

${ }^{101} \mathrm{O}$ que era uma boa metodologia, pois desta forma não se permitia ao material calcinado absorver a umidade do ar, o que o levaria a extinguir-se, e posteriormente, úmido e em contato com o gás carbônico presente na atmosfera, se carbonatasse.

102 Outros autores são favoráveis a esta idéia, mas Vitrúvio nada mencionou especificamente a respeito.

${ }^{103}$ DE L'ORME. Philibert: Le premier tome de l'architecture..., L. I, Cap. XVI, fls. 27.

${ }^{104}$ GUIMARÃES, José Epitácio Passos. A cal..., p. 256/257 - A cal virgem é considerada como gorda quando apresenta um teor de óxido de cálcio superior a 90\%. Esta cal é também conhecida como cal rica, em contraposição à cal (virgem) magra (cálcica ou dolomítica).

${ }^{105}$ Como não se encontrou uma tradução adequada para a denominação deste instrumento, cujo emprego era comum, ao menos no século XVIII, para misturar argamassas, é apresentada no anexo 1 a reprodução de gravura com ilustração do mesmo, assim como fotos de exemplares encontrados em Lisboa. Destaca-se, inclusive, que esta era a mesma denominação dada a determinado tipo de plaina, usada por carpinteiros e pedreiros. 
${ }^{106}$ DE L'ORME, Philibert. Le premier tome de l'architecture..., L. I, Cap. XVI, fls. 28.

${ }^{107}$ Cassostreæ rhyzophoræ.

108 Leucina pectinata - Assim como as ostras, as lambretas são moluscos bivalves, presentes em grande escala no litoral da Bahia.

${ }^{109}$ LEÃO, Zelinda Margarida A.N.. Guia para identificação dos corais do Brasil. Salvador: PPPG/UFBA, 1986.

${ }^{110}$ Considerando-se a média de três ensaios.

${ }^{111}$ Cais provenientes de pedra lioz, de mármore branco e de cascas de lambretas.

${ }^{112}$ SCAMOZZI, Vincenzo. L'idea della architettura universale..., t. II, Parte II, L. VII, Cap. II, p. 178. - E parlando delle calcine ancor esse bagnate, e conservate nelle fosse si sgallano, e si disfanno, e macerano meglio, perilche rendonsi di maggior fattione, e sono, più trattabili, e di miglior pasta, \& hanno maggior nervo, e forza, onde per consequenza risultano di maggior presa nelle mura.

${ }^{113}$ /d., ibid., t. II, Parte II, L. VII, Cap. XIX, p. 229.

${ }^{114}$ GUIMARÃES, José Epitácio Passos. A cal..., p. 182.

${ }^{115}$ SAVARY, Diccionario de commercio e industria..., v. I, verbete cal, p. 356.

${ }^{116}$ NBR-6472 - Cal - Determinação do resíduo de extinção. Rio de Janeiro: ABNT, Junho/93.

117 VASCONCELLOS, Ignacio da Piedade (Pe.), Artefactos symmetriacos, e geometricos. Lisboa Occidental: Joseph Antonio da Sylva, 1733. p. 377.

${ }^{118}$ ASHURST, Jonh, Mortars, plasters and renders in conservation. Londres: EASA/RIBA, 1983. p. 9/10.

${ }^{119} \mathrm{~A}$ areia é normalmente constituída por sílica, mineral considerado como não reativo.

${ }^{120}$ BELIDOR, Bernard Forest de. La science des ingenieurs..., L. III, Cap. III, p. 8.

${ }^{121}$ NEGREIROS, Jozé Manuel de Carvalho. Jornada pelo Tejo ..., fls. 144v.

${ }^{122} \mathrm{Ou}$, em linguagem atual, tinha propriedades higroscópicas.

${ }^{123}$ EÇA, Mathias Ayres Ramos da Sylva de. Problema de architectura civil..., Parte I, Cap. XI, p. 201 // NEGREIROS, Jozé Manuel de Carvalho, Jornada pelo Tejo..., fls. 147v.

${ }^{124}$ EÇA, Mathias Ayres Ramos da Sylva de, Problema de architectura civil..., Parte I, Cap. X, p. 174/175 // NEGREIROS, Jozé Manuel de Carvalho, Jornada pelo Tejo..., fls. 144v.

${ }^{125}$ NEGREIROS, Jozé Manuel de Carvalho. Additamento: ao livro Jornada pelo Tejo..., v. III, fls. 48.

${ }^{126}$ NEGREIROS, Jozé Manuel de Carvalho. Jornada pelo Tejo..., fls. 145.

${ }^{127}$ BOUILLET, M. N., Dictionnaire universel des sciences, des lettres et des arts..., verbete "sel", p. 1571 - Conforme este dicionário, a composição do sal marinho, por exemplo, só foi estabelecida por Margraff, na segunda metade do século XVIII.

${ }^{128}$ NEGREIROS, Jozé Manuel de Carvalho. Jornada pelo Tejo..., fls. 144 - Esta citação é praticamente igual àquela existente no texto de Mathias Ayres (EÇA, Mathias Ayres Ramos da Sylva de, Problema de architectura civil, Lisboa, Antonio Rodrigues Galhardo, 1777. Parte I, Cap. IX, p. 169-170).

${ }^{129}$ CATANEO, Pietro. I quattro primi libri di architettura..., L. II, Cap. V, fls. 29v. 
${ }^{130}$ GUIMARÃES, José Epitácio Passos. A cal..., p. 91.

${ }^{131}$ MARTINI, Francesco di Giorgio, «Architettura civile e militare»..., v. III, t. II, tratado I, p. 317. - Um calcário marmoso do qual se extrai cal hidráulica ou cimento de pega rápida.

${ }^{132}$ VITRUVIO, Marco Lucio. Los diez libros de arquitectura, tradução de Agustín Blánquez..., L. II, Cap. V, p. 44.

${ }^{133}$ CATANEO, Pietro, I quattro primi libri di architettura..., L. II, Cap. V, fls. 29v - Conosci la bontà della calcina, se, cotta che egli è, pesa il terzo manco, che non pesava prima la sua pietra [...] // Conhece a bondade da cal se, cozida, pesa dois terços do que pesava antes a pedra que a originou...

134 [RODRIGUES, António], [Tratado de arquitectura] ..., Cap. VII, fls. 17.

${ }^{135}$ Em unidades de massa atômica, $\mathrm{Ca}=40, \mathrm{C}=12 \mathrm{e} \mathrm{O}=16 ; \mathrm{CaCO}_{3}=100$ u.m.a., $\mathrm{CaO}$ $=56$ u.m.a., $\mathrm{CO}_{2}=44$ u.m.a.

${ }^{136}$ Caso do mármore ensaiado.

${ }^{137} \mathrm{O}$ peso molecular do Mg é 24 u.m.a.

${ }^{138}$ BRANCA, Juan. Manual de arquitectura..., L. I, Cap. III, p. 8-9.

139 PFEFFINGER. Fortificaçam moderna, trad. de Manoel da Maia. Lisboa: Officina Real Deslandesiana, 1713 - No L. IV, Cap. XVII, §III, p. 226 a 229, podem ser encontrados exemplos do uso da cal viva no caso de fundações em locais úmidos ou dentro d'água, o que também pode ser notado em outros dos textos consultados.

${ }^{140}$ WINGATE, Michael. Small-scale lime-burning..., Cap. III, p. 25.

${ }^{141} \mathrm{O}$ mesmo se deu na análise da matéria-prima usada na sua confecção.

${ }^{142}$ HERATH, J. W. «Lime industry in Sri Lanka», HILL, Neville, HOLMES, Stafford, MATHER, David, Lime and other alternative cements..., Cap. VII, p. 56-64. p. 61.

${ }^{143}$ BAj, cota: 51-IX-21, p. 40. Carta sobre fortificação de Angola.

${ }^{144}$ PETRUCCI, Eládio G. R.. Materiais de construção, 8 a ed.. Porto Alegre: Globo, 1987. Cap. VI, p. 326.

${ }^{145}$ GUIMARÃES, José Epitácio Passos. A cal..., p. 91.

${ }^{146} / d$., loc. cit.

${ }^{147}$ PETRUCCI, Eládio G. R.. Materiais de construção ..., Cap. VI, p. 327.

${ }^{148}$ BRANCO, J. Paz, Manual do pedreiro. Lisboa: LNEC, 1981. Cap. I, p. 41.

149 GUIMARÃES, José Epitácio Passos. A cal..., p. 91 e 266.

150 SANTIAGO, Cybèle C., KORN, Maria da Graça A., AMARAL, Allard M. do, OLIVEIRA, Mário M. de. «Estudo comparativo entre cais usadas em argamassas antigas», Anais do congresso "Quarry - Laboratory - Monument" International Congress - Pavia 2000. Setembro, 26-30, 2000. Pavia, G. Calvi e U. Zezza.v.1. p.511-516. p.515. 


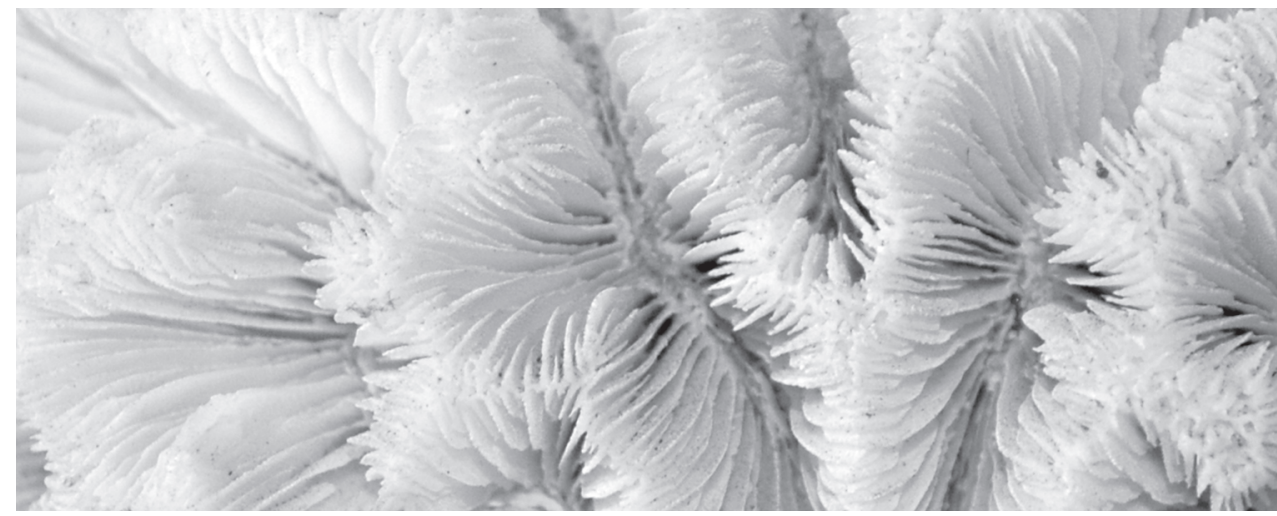

Areía 
O material denominado areia, na acepção atual, é composto por um determinado tipo de partículas presentes no solo, partículas essas cujas dimensões estão contidas em uma faixa granulométrica específica $(0,15$ $4,8 \mathrm{~mm})$. De modo que até mesmo a pozolana foi considerada, antigamente, em vários textos anteriores ao século XIX, como uma areia. Suas características, contudo, serão comentadas oportunamente.

No entanto, apesar de constituir-se em uma fração granulométrica específica do solo, as areias distinguem-se das argilas, siltes e pedregulhos, não apenas pelo tamanho de seus grãos, mas também pela sua constituição mineralógica e química.

Composta geralmente por silicatos (quartzo), as areias quase não apresentam reatividade, daí serem normalmente consideradas como inertes. No entanto, podem também ser encontradas areias carbonáticas, dependendo do tipo de rocha a partir do qual foi gerada. Isso ocorre, por exemplo, na Península de Yucatán, México, região de solo eminentemente calcário, cuja areia de praia (Praia de Cancún), analisada no NTPR, apresenta em sua constituição 95,5\% de carbonato. Esse tipo de areia, ao que parece, não era comum nos locais utilizados até o século XVIII como fontes de matérias-primas para as construções, pois são encontradas na bibliografia recomendações do uso de ácido para demonstrar que a areia não era atacada por este produto.

O primeiro texto encontrado indicando as qualidades e características das areias como material de construção foi o tratado de Vitrúvio. Assim como as demais informações dadas sobre outros materiais, o que este autor escreveu sobre as areias foi repetido pela maioria daqueles que 0 
sucederam, que eventualmente complementaram a informação do mestre romano ou até mesmo fizeram alguma espécie de crítica. Vitrúvio não deu uma definição específica para o material, mas descreveu os diversos tipos que conhecia e sua utilização.

Segundo Vitrúvio, deveria ser dada preferência à areia de jazida, que secava rapidamente, suportava peso e, quando usada em revestimento, propiciava sua boa durabilidade. No entanto, esse tipo de areia, se recémescavado, era inconveniente para rebocos (misturado com palha e cal), por fissurar. Por outro lado, não poderia permanecer exposto às intempéries por um período muito longo, para não se deteriorar.

$\mathrm{Na}$ falta desta, recomendou usar a de rio, a melhor de todas, em sua opinião, para estuque. A de mar podia ser usada em último caso, mas demorava a secar, não suportava o carregamento e os sais nela presentes afetavam o reboco ${ }^{1}$.

Giovanni Branca informou que alguns autores acreditavam que a areia era um conjunto de pequenas pedras. Na opinião destes, a melhor era aquela que entrasse em menor quantidade em uma medida de $\mathrm{cal}^{2}$.

Considerar a areia como um conjunto de pedras pequenas fazia até algum sentido. Porém a referência à argamassa forte, como sendo indicativa da boa qualidade da areia, está truncada. Na realidade, é da qualidade da cal que ela depende. Sabe-se, hoje, que a participação da areia $\left(\mathrm{SiO}_{2}\right)$ nas argamassas dá-se apenas no sentido de redução do custo e alteração da porosidade do material resultante. Logo, quando a cal é de boa qualidade, ela comporta muita areia, formando uma boa argamassa, e barateando o custo da obra. Se a areia for igualmente de boa qualidade e puder entrar em maior quantidade na argamassa, melhor, pois reduzirá as despesas da construção sem se constituir em uma fonte de problemas.

Giovanni Branca recomendava ainda preparar uma argamassa para identificar se a areia apresentava características desejáveis à construção, já que até o momento não havia ensaios laboratoriais de caracterização do material. Deste modo, o veredito final possivelmente era dado com base no traço que, na prática, fosse considerado como adequado à execução da obra. Briseux também recomendou que assim se procedesse, sugerindo, inclusive, que fosse feita uma pequena parede-teste, de modo que, após secagem, pudesse ser verificada a capacidade de aderência da $\operatorname{argamassa}{ }^{3}$. 
Esta observação não é de todo válida, pois como outros autores informaram, nem só da qualidade da areia depende a excelência da argamassa, mas também da bondade da cal (e da água), sem esquecer todavia a elaboração da mistura. Além do mais, as propriedades da argamassa também dependem do uso ao qual ela se destina. Porém a informação serve ao menos como indicativo da preocupação que os autores tinham pela boa qualidade do material e aplicação de método experimental empírico.

É, contudo, interessante a metodologia recomendada por Briseux: elaborar-se um protótipo para tentar prever o comportamento do material após a aplicação. Em muitos casos, principalmente quando se trata de uma obra de conservação e restauração, isto é atualmente indicado, dentro do princípio da prudência que tanto recomendou Piero Sanpaolesi ${ }^{4}$ (séc. XX).

No texto setecentista Principii di architettura civile, atribuído a Milizia, a areia foi definida da seguinte forma:

Uma grande quantidade de partículas separadas, rígidas, cristalinas, impenetráveis à água, indissolúveis à água-forte, cintilante à percussão com haste metálica, resistente ao fogo e vitrificáveis ${ }^{5}$.

Embora, naquela época, não se conhecesse bem a constituição dos materiais (inclusive, no mesmo capítulo em que se encontrou a citação acima, verificou-se que ainda foi falado ser a areia composta por sais ${ }^{6}$ ), pode ser notado que, pelo menos, o autor do texto já havia considerado vários aspectos do material. No entanto, algumas das observações estavam erradas e outras, incompletas. Por exemplo, as areias carbonáticas reagem com o ácido, dissolvendo-se e liberando gás carbônico (o que não foi indicado) e, apesar de imperceptível, o grão de areia apresenta porosidade. No Brasil, existe uma norma para avaliá-la, na qual os grãos são moídos e submetidos ao vácuo ${ }^{7}$.

\section{Formação das areias}

Atualmente, sabe-se que a origem das areias é a fragmentação de diversos tipos de rochas, basicamente por ação do intemperismo, processo para o qual concorrem os animais e vegetais, o gelo-degelo, as variações de temperatura, as águas e os deslizamentos, dentre outros fatores naturais menos comuns. Porém, até mesmo o homem pode dar a sua colaboração 
para que isto ocorra, como acontece na formação dos solos em geral. Pode, também, por britamento, fabricar, por assim dizer, areia. São as chamadas areias artificiais.

As areias naturais são encontradas em jazidas, nos leitos dos rios, à beira-mar ou nas proximidades deste, em dunas. Pelo fato de apresentarem origem diversificada, os vários tipos de grãos que compõem as areias possuem, como era de se esperar, coloração e composição mineralógica diversas.

Pelo que se pode depreender dos textos antigos, a origem das areias era um assunto envolvido em um grande mistério, mas as areias eram classificadas conforme o local onde se acumulavam em maior quantidade (areia de rio, de jazida ou de mar).

Alguns dos autores consultados acreditavam, por exemplo, que a origem de algumas areias estava na queima de um determinado tipo de terra por um fogo subterrâneo. O próprio Vitrúvio assim mencionou, ao citar a areia denominada "carbúnculo"8. Segundo Paolo Portoghesi, comentarista de uma das edições atuais do tratado de Alberti, o "carbúnculo" era uma areia que apresentava fragmentos rochosos negros ${ }^{9}$, mas ainda há dúvidas sobre a identificação correta deste material.

Alberti atribuiu a formação de areia à fragmentação das rochas ${ }^{10}$. Scamozzi foi mais além, ao acrescentar que isto se dava por ação das intempéries e do transporte fluvial'11, o que não foi verificado em outros textos, e já reflete a realidade tal qual como hoje a compreendemos. O profundo senso de observação e a intuição dos antigos por vezes conseguiam justificar alguns fenômenos, o que as ciências ainda não tinham tido condições de fazer.

Nos textos do século XVIII, entretanto, notou-se com freqüência que muitos autores não faziam a menor idéia deste processo: atribuíam, por exemplo, a formação da areia à água, não como agente de fragmentação das rochas, nem de transporte, mas como gerador da areia. Pelo menos essa é a impressão que tais autores passaram em seus textos.

Segundo o autor do livro Memoires critiques d'architecture, as areias podiam ter duas origens: ou teriam criação divina, sendo por conseguinte tão velhas quanto o planeta Terra, ou eram formadas pela união de sais e terra, a exemplo da maioria das areias de rio. A diferença fundamental entre estes dois tipos de areia, em sua opinião, era que as formadas 
desde a criação do mundo continham terra, enquanto que as formadas diariamente não a possuíam, por serem constantemente lavadas pelas águas $^{12}$.

A natureza das areias surgidas juntamente com a Terra dependia, para o autor de tal texto, da ordem do Criador e do ambiente no qual estavam presentes. Ainda conforme o mesmo autor, nos locais mais áridos, as areias eram mais secas e menos terrosas; em locais que apresentavam umidade relativa mais elevada, as areias seriam mais úmidas e mais terrosas do que aquelas formadas nos locais mais secos ${ }^{13}$ :

Sobre isto, eu creio que onde as terras são úmidas, a areia que aí se encontra é mais doce, pois a umidade, amolecendo todos os seres onde ela está presente, as areias que estão nestes locais têm menos sais e, conseqüentemente, menos aridez e secura ${ }^{14}$.

Notou-se, na passagem acima, a crença no fato da areia possuir sais, o que não confere com o conceito que se tem hoje do material. Possivelmente, por esta razão é que este autor deveria imaginar que a água, estando presente em grande quantidade, causaria a sua lixiviação. Só que, se assim o fosse, quanto menor a quantidade de sais presentes, mais secas deveriam ser as areias.

No texto atribuído a Fremin, consta ainda que as areias que todos os dias eram geradas não se encontravam em jazidas, mas sim dispersas em vários locais, e os grãos que as compunham apenas se reuniam por meio das chuvas. Estas, por lixiviação, os transportavam para os rios, onde tais areias podiam ser coletadas para desempenharem o seu papel na construção.

Pode-se perceber que tais afirmações realmente não tinham nenhuma base científica. A justificativa encontrada para as mesmas é que, como não se tinha domínio das ciências a ponto de dar-se uma explicação plausível para determinados fenômenos, apelava-se para algo imperceptível aos olhos humanos (por exemplo, algo que ocorria sob o solo), ou para o sobrenatural (um ato do Criador).

A geologia e a mineralogia, ciências complementares cujo entendimento é fundamental para uma boa compreensão acerca da formação das areias, só vieram a se desenvolver em finais do século XVIII. Nesta época, já se sentia a necessidade do conhecimento mais profundo 
deste material, conforme pode ser verificado, por exemplo, através da citação de Mathias Ayres, reproduzida por Negreiros:

[...] he preciso conhecer aquella materia commumente conhecida ${ }^{15}$, mas não conhecida, ou bem entendida commumente $[\ldots]^{16}$.

Quanto à afirmação que as areias eram formadas por sais, era um reflexo da falta de desenvolvimento da química. J. F. Blondel, por exemplo, ao diferenciar a areia dos pedregulhos e das pedras, também demonstrou acreditar nisto:

[...] é uma espécie de pedregulho de diferentes tamanhos de grãos. É diáfana ou opaca, rude, áspera, tosca e sonora, segundo a qualidade diferente dos sais com os quais é formada, e dos diversos terrenos onde se acha ${ }^{17}$.

Ou seja, em sua opinião, eram exatamente os sais que constituíam as areias os responsáveis pelas suas características.

A informação mais curiosa, entretanto, acerca da gênese das areias, aparece no texto de Mathias Ayres, reproduzida em Jornada pelo Tejo, de Negreiros: algumas pessoas consideravam a areia como "uma terra como qualquer outra, só distincta na figura, mas indistincta nos effeitos". Negreiros, entretanto, acrescentou não compartilhar desta opinião, pois julgava que a areia também apresentava "todos os seus effeitos distintos", já que era possível, por exemplo, obter-se vidro misturando areia com barrilha. Isto não ocorreria se a terra fosse usada na mistura.

A respeito deste assunto, Mathias Ayres deu ainda a seguinte informação, repetida por Negreiros:

Não he pois a areia actualmente terra nem especie alguma della; a duvida só pode subsistir, em se foi terra antes de ser areia; questão esta muito duvidoza.

A opinião mais seguida na fyzica hé, que a areia he um corpo solido, fuzivel, e cristalino; sendo examinada com o microscopio, he verdadeira produção da agoa, para o que não intervem algum outro corpo manifesto; Por isso, aonde ha agoa, ha commu'mente areia. [Nas praias, nas margens dos rios, não por serem levadas pelas torrentes, mas] porque nestas mesmas, se forma a areia, como se forma igualmente em todo o ambito da terra donde as agoas deixam huma especie de fermento lapidifico, que com o calôr do sól, ou da mesma terra, fica conversivel, e se converte em areia verdadeira ${ }^{18}$. 
Mathias Ayres, no entanto, discordou da existência de um líquido com a capacidade de gerar areia, justificando que, apesar de muitos defenderem essa opinião, nunca uma pessoa ao menos o tinha visto:

O haver nas entranhas da terra hum succo «lapidifico» he o mesmo que suppôr a existencia de hum corpo physico, que só he considerado mentalmente; porque na verdade nunca foi visto, nem achado ${ }^{19}$.

Curiosamente, o próprio Mathias Ayres afirmou que existiam fatos na face da terra aos quais não se podia atribuir uma razão lógica, apesar de observados com freqüência. Para exemplificar esse seu pensamento, narrou a geração instantânea de sapos, sempre que ocorria uma tempestade súbita em uma região onde o solo fosse argiloso e estivesse bastante ressecado, como muitos já haviam tido a oportunidade de constatar $^{20}$.

Continuando com as considerações de Negreiros sobre a formação das areias, tem-se também:

Nos lugares subterraneos em que o callor he forte, e na superficie da terra onde o sol he mais intenso, ahi se forma a areia abundantemente; porque todas as materias seminaes, e productrizes, necessitão de callor para terem lugar as acçoens que Ihes são proprias; e regularmente sem callor a Natureza não obra; e nos compostos artificiaes, aquillo que se Ihe faz he com fôgo; sendo certissimo o axioma que diz, - In sole, et sale, natura sunt omnia ${ }^{21}$.

Ou seja, Negreiros defendia igualmente que o "fermento lapidifico" só agiria em presença de calor intenso, subterrâneo ou solar.

Sua idéia sobre o assunto não tinha, realmente, fundamento: a água e o calor são apenas coadjuvantes no processo, mas o "ator principal" do processo é a rocha, cuja participação nem foi cogitada.

Com relação à substância contida na água, e que forma a areia, tem-se que:

Aquella mesma colla, ou gluten que a agoa tem, e que por meio do callor e successão do tempo he transmutavel em areia; tãobem he a primeira cauza, ou origem primitiva, de toda a vegetação22.

Ainda no intuito de diferenciar terra de areia, Negreiros disse que em lugares subterrâneos havia água, minerais e areia, mas raramente terra, e que a areia não alterava seu aspecto e consistência na água. Além do 
mais, as areias eram compostas por partículas indivisíveis e não sofriam variações volumétricas ${ }^{23}$.

Notou-se que o autor, ao emitir sua opinião a respeito da areia, tentou fazer, na medida do possível, uma observação minuciosa do material. Constatou, inclusive, que este material era composto por grãos que apresentavam uma determinada dimensão, que não era alterada em si, por exemplo, pela ação da água, como ocorre com a argila, permanecendo sempre do mesmo tamanho. O que Negreiros não percebeu foi que, quando o grão de areia entra em contato com a água, esta adere à sua superfície, causando o chamado inchamento, variação entre o volume úmido e o volume seco do material.

Ainda com relação à preferência notada nos textos antigos sobre determinados tipos de areia, Mattheus do Couto relacionou, em ordem decrescente, quais eram, na sua opinião, as melhores areias a serem utilizadas na construção:

[...] saybro, q he hu'a aréa alionada, e sobre o grosso, e não muito solta

[...] e sem pó algum; areia de jazida; areia de rio; areia de mar $^{24}$.

Eis que surge um problema, quando da análise da passagem acima, sob o ponto de vista do conhecimento atual: é muito difícil afirmar, sem medo de errar, qual o material considerado na época como saibro, já que várias definições foram encontradas nos diversos documentos investigados. Seguramente não é o que hoje se conhece com esta denominação no Brasil, pois a característica básica do material é conter "pó" (argila).

Frei Bernardo de São Bento faz referência a certa argamassa feita com água, saibro e cal. Segundo Silva-Nigra, que transcreveu e comentou esse trabalho, saibro era simplesmente uma "areia grossa misturada com pedrinhas roladas" 25 . Nesta definição poderia ser, talvez, enquadrado o saybro mencionado por Mattheus do Couto.

Na opinião de Diogo Vellozo, saibro era apenas o nome dado à areia de jazida, material, em sua opinião, melhor do que a areia fluvial26 .

Já Negreiros o descreveu da seguinte forma:

O saibro commu'mente chamado he uma areia imperfeita, cuja baze he huma terra delgada com similhança de areia; porquanto o verdadeiro saibro he raro; e o que for verdadeiro he como a melhor areia; mas 
quazi sempre [...] [aproveitam-se] do que achão mais perto da obra sem sellecção ${ }^{27}$.

Para descobrir a areia legítima, este autor sugeriu a colocação de uma amostra do material a ser identificado dentro de um frasco com água, e a posterior observação do seu comportamento. Este procedimento nada mais era do que um processo de sedimentação:

[...] a verdadeira areia deve logo precipitarse ao fundo, deixando a mesma agoa clara, sem cedimento terreo na sua parte superior; e a que não he verdadeira, deixa a agoa turva por algum espaço, imprimindoIhe a côr que the he propria, até que fazendo assento sobre a areia, mostra distinctamente o que he terra na parte superior, e na parte inferior o que he areia; esta como mais pezada, assenta logo, e a outra como mais leve sustenta-se mais tempo encorporada na agoa, até que tãobem se precipita sobre a areia em forma de polme ou limoterreo ${ }^{28}$.

Pela descrição dada e pelo tipo de teste prático indicado, concluiu-se que o material identificado como saibro por Negreiros - em sua opinião, a areia que não é verdadeira, ou uma areia imperfeita - deveria ser o mesmo que hoje, no Brasil, recebe esta denominação ${ }^{29}$. Isto por consistir em um solo constituído por uma fração de areia, porém apresentando um teor elevado de silte e argila, daí ser considerado como uma "massa um tanto líquida"30. Só que, pela explicação dada por Negreiros, não ficou claro qual seria o saibro verdadeiro, que seria tão bom quanto a melhor areia.

No texto de Briseux, encontrou-se referência ao uso alternativo, nas argamassas, de um material denominado petite argille. Aparentemente, este seria o saibro, no atual conceito dado à palavra, no Brasil:

[...] petite argille, que é uma terra amarela, arenosa e um pouco gorda. Aquela que encontramos sob a grosse argille é a melhor, e aproximase mais da areia: deve-se recusar aquela que se encontra na superfície da terra, e pegar apenas a argila que está embaixo. Este tipo de terra consome mais cal que a areia e faz-se necessário redobrar sua atenção, ao usá-la para fazer argamassa, pois sendo mais difícil de ser misturada, os operários colocam muita água, e esta argamassa mal misturada, não tendo qualquer resistência, reduz-se facilmente a pó tão logo seca ${ }^{31}$. (o interessante é que este autor recomendou textualmente que não fosse usada areia contendo terra)

Em Portugal, atualmente, o saibro, segundo alguns autores, é um material composto por uma mistura de argila, areia grossa e pedras ${ }^{32}$. A definição que se encontrou para o saibro, em um dicionário do século XIX, foi: 
SAIBRO, s.m. do lat. sabulo ou gearea, fr. gravier, it. sabbia, (archit.) areia grossa e escura ou vermelha, composta de pedrinhas globosas, extrahida das margens do mar e dos rios, que serve para fazer boa argamassa, especialmente para a que chamam 'formigão', e tem outras aplicações uteis na arte de edificar ${ }^{33}$.

Atualmente, em argamassas de cal, o saibro também é utilizado, sem que isto seja a causa da geração de problemas em não se conseguir uma boa união desses dois materiais, como aventado por certos autores antigos.

\section{Caracterização}

Além de definições e considerações diversas acerca da origem das areias, são abordados, nos textos consultados, outros aspectos, tais como: a distinção conforme o local de onde são extraídas; a presença de terra juntamente com os grãos; sua coloração; a aparência dos grãos; o uso ao qual se destina o material. Alguns destes aspectos estão por vezes interrelacionados, daí nem sempre poderem ser tratados isoladamente.

Vitrúvio chamou a atenção para o fato de que as areias não podiam conter solo, no que vários autores concordavam, o que já foi comentado. Baseado neste princípio ensinou, e foi exaustivamente repetido, um teste prático que servia para a identificação das areias adequadas: apenas aquelas que não manchassem um lenço branco eram boas para a construção.

O padre italiano da Companhia de Jesus, Federico Sanvitali, indicou, igualmente, para as argamassas, areia sem terra. Completou a informação dizendo que a areia deveria ser composta por grãos de tamanho médio. Isto porque, se fosse muito fina, quando usada na argamassa, não the conferiria consistência e causava o seu esfarelamento. No caso de utilizada a areia de rio, sugeriu que ela fosse retirada de preferência do meio do seu leito. Poderia ser usada a areia da margem, desde quando eliminada a camada superficial, para se excluir a presença da terra ${ }^{34}$, o que foi ratificado por Jombert ${ }^{35}$.

J. F. Blondel também concordou com a opinião dos autores acima, o que pode ser comprovado na citação extraída do seu texto Cours d'architecture: 
A areia de rio é a melhor para fazer boa argamassa, tendo sido batida pela água e encontrando-se por isso liberada de todas as partes terrosas da qual ela se origina ${ }^{36}$.

Christiano Rieger disse que a areia só se uniria bem com a cal e com os elementos das alvenarias se estivesse completamente seca e fosse áspera, daí a inconveniência de seu uso em mistura com terra:

A areia não deve ser nem muito gorda, nem muito magra, pois a primeira não é muito adequada para o trabalho, e menos ainda a segunda, que nunca se une bem com a cal ${ }^{37}$.

O arquiteto francês Pierre Patte concordou com Vitrúvio quanto às características das areias, mas sugeriu um teste diferente para verificar se o material continha ou não elementos terrosos: pegar uma pequena porção da areia a analisar e lavá-la em água quente dentro de um vaso, a princípio agitando-a bem, e depois reduzindo a velocidade, de modo a permitir o assentamento das partículas mais pesadas no fundo. Em seguida, escoar a água, que carrearia as partículas finas. Pesando-se o material antes e depois desta operação ${ }^{38}$, ter-se-ia condições de verificar qual a quantidade de partículas terrosas ${ }^{39}$ que estavam misturadas com os grãos de areia ${ }^{40}$. Tal procedimento é uma técnica viável do ponto de vista analítico. Quanto ao uso de água quente, serviria para dissolver os sais solúveis eventualmente presentes no agregado e funcionar como defloculante.

Como informação adicional, para justificar a recriminação do uso de areia misturada com terra, no texto atribuível a Milizia foi ensinado que terra crua e cal não se combinavam ${ }^{41}$. $O$ interessante é que este texto foi escrito no século XVIII, e já se tinha noção há algum tempo da combinação desses dois materiais, pelo menos no caso da estabilização de solos. À guisa de exemplo, cita-se que o mestre das obras da Cidade de Salvador, Luís Dias, por ocasião de sua fundação, no século XVI, em carta enviada ao Reino, contou que as muralhas de taipa de pilão da cidade não eram resistentes por serem mal feitas, exatamente pelo fato de serem um pouco altas para taipa sem cal, conforme indicado na transcrição parcial do documento efetuada em um texto contemporâneo ${ }^{42}$.

Andrea Palladio aceitou a indicação de Vitrúvio para não empregar areia que contivesse argila ${ }^{43}$. O interessante, quanto a este aspecto, é que a maioria dos autores sempre repetiu esta informação, porém nenhum 
deles afirmou ter utilizado areia misturada com argila, para comprovar que a argamassa não apresentava as características requeridas. Provavelmente, consideravam como verdade o que lhes era transmitido, sem o menor questionamento, visto que as reflexões neste sentido só vieram a se desenvolver em época posterior, com Descartes. Infelizmente, ainda hoje podem ser encontrados autores que se comportam de maneira similar àqueles anteriores ao século XVIII.

No texto atribuído a Fremin foi declarado que a areia fluvial era a melhor (opinião contrária à de vários outros autores) para argamassas, pela menor quantidade de elementos terrosos que continha. As areias de jazida, embora fossem também boas, deviam ser lavadas, para se conseguir eliminar as partículas de terra ali presentes ${ }^{44}$. Notou-se, pois, a concordância deste autor com aquilo que Vitrúvio dizia, quanto ao fato da presença de solo ser prejudicial às argamassas. A justificativa dada era que a terra bloquearia a porosidade da pedra e impediria a penetração da cal.

Na realidade, a depender do tipo de argilomineral presente, a terra poderia ser prejudicial à argamassa, porém na maioria dos casos isto não ocorria. Para ser considerada como adequada à construção, a areia deve ser isenta de impurezas orgânicas, apresentar baixa ou nenhuma reatividade química e apenas um certo percentual de silte e/ou argila.

Quanto à proveniência, Vitrúvio ensinou que havia areias de rio, de jazida ou de mar, sendo este último tipo inconveniente para as argamassas, mas com eventual possibilidade de utilização. Faventinus e Palladius Rutilius concordaram com Vitrúvio que a melhor areia era a de jazida, e que este material não deveria conter solo ${ }^{45}$.

Na concepção do Padre Vasconcellos, a areia de rio não apresentaria bons resultados em uma argamassa porque ficaria sempre úmida ${ }^{46}$, o que não é verdade, tanto que, hoje em dia, areias desta proveniência são muito utilizadas. Possivelmente, o que ocorria era que os pedreiros deviam empregar a areia das margens do Tejo em trechos onde a água era salobra, à semelhança do que acontecia no caso do preparo da cal de Alcântara, que apresentava alguns problemas pelo fato de utilizarem a água do rio, naquele local, porque esta já continha sal ${ }^{47}$. A presença de sal na argamassa faz com que, por higroscopicidade, este material, após seco, absorva a umidade do ar e apresente manchas, e mesmo desagregação. 
Ao discorrer sobre características e qualidades das areias, Alberti opinou que, dentre as de jazida, a carbunculosa era a mais indicada para a confecção de argamassas, e a branca a menos, seguindo-se da ghiaia di tipo più fine, specialmente se è di forma poligonale e affatto pura da mescolanza con la terra ${ }^{48}$. Depois, a areia de rio (do meio do leito e sob a primeira camada, para que o material coletado não contivesse impurezas) e, por último, a areia de mar" ${ }^{49}$.

Cataneo, ao referir-se às areias a serem empregadas na construção, por exemplo, concordou com Vitrúvio na classificação quanto aos tipos e cores existentes, e recomendou o mesmo teste prático para verificação da presença de terra ao qual já se fez referência, afirmando:

[...] e de todo modo deve-se fugir daquelas areias que apresentem terra e lodo ${ }^{50}$.

Citação semelhante foi encontrada em outros textos de mesma época ou escritos posteriormente a / quattro primi libri di architettura. Na realidade, é comum notar-se que alguns dos textos estudados apresentam transcrições de outros mais antigos, de modo que um autor fazia suas as idéias do seu antecessor.

No capítulo referente às propriedades da cal, do tratado atribuído a Antônio Rodrigues ${ }^{51}$, por exemplo, ao ser mencionado o uso da areia do mar nas argamassas, tem-se que este autor também recriminava o uso de areia misturada com terra e com sal, e recomendava a sua lavagem:

[...] de todas as tres sortes que ha de area, as quais são area do mar, area do ryo, e area da cava, a da cava é a melhor de todas, por ser myneyro predozido por sua natureza he não per artefisyo, como he area do ryo e do mar; a qual é por artefisio predozida, porque area do ryo e a do mar não he outra couza emge'drada senão da terra que cay no ryo, e a agoa lava esta terra e o que fica por ser grave se vay ao fundo e fica em area.

Esta sorte de area, por seu nasymento ser mesturado cõ a propria terra, não he tam perfeyta como aquela harea que he preduzida per myneyro de sua natureza propria. H'area de mar é de todas as tres sortes a peor per duas rezoys: - a permeira he que yamais se podera tomar desta area que não traga po hou tera cõsygo, ha segunda he que por ser assalitrada não pode fazer boa preza cõ a cal. Portamto se deve de fogyr que com esta tal sorte de area se não fabryque nenh'ua couza, salvo se a nesesidade ho costramger a fazer. E sendo costragydo de nesesydade Ihe buscarão remedio pera que se poçam servir dela, ho 
qual sera que amtes que seya traçada cõ a cal sera esta area muyto bem lavada em agua dose para Ihe tirarem ho salytre e o po que tem, he emtamses despois de lavada emtão a traçarão cõ a cal [.... $]^{52}$.

Segundo este texto, a melhor areia para construção era, pois, a de jazida, seguida pela de rio. A de mar só deveria ser usada em última instância. A razão para a de jazida ser considerada como a melhor era por ser isenta de terra e de sal. Destaca-se que, dentre os autores consultados, nenhum ignora os problemas decorrentes da existência de sais nas argamassas. Quando alguns permitiram o uso da areia de mar, fizeram-no normalmente com ressalvas.

Se fosse imprescindível o uso de areia de mar, a lavagem realmente era uma boa opção. Só que, pela leitura dos diversos textos, notou-se, por exemplo, que, no caso da extinção da cal, a água do mar era usada com freqüência. Logo, se esta precaução, que era mais fácil de ser seguida, não era tomada, não se acredita que a areia de praia fosse lavada. Aliás, a utilização da areia salgada ocorre até hoje, pois certos fornecedores não criteriosos vendem o material sem alertar os consumidores para a sua proveniência.

Quanto à presença de terra na areia do mar, isto só deveria ocorrer quando a areia fosse retirada nas proximidades da foz de algum rio, ou em zona bem próxima da margem, onde havia argila.

Vitrúvio receitou ainda o uso de areia de rio na execução de reboco fino, por ser um material menos "gordo", e admitiu o uso da areia do mar na confecção das argamassas, caso não se dispusesse de outra ${ }^{53}$. Alberti, contudo, lembrou que até mesmo dentre as diversas areias marinhas havia aquelas de grão mais grosso, que deveriam ser preferidas ${ }^{54}$.

Andrea Palladio, ao mencionar as características das areias, disse que as de rio se prestavam a revestimento; as de jazida, por fendilharem muito, deviam ser destinadas a argamassas de assentamento; as de mar, por secarem muito rápido, umedecerem novamente com igual rapidez e se desfazerem por causa dos sais, não suportavam cargas ${ }^{55}$.

No texto atribuível a Milizia, foi comentado que a areia fluvial diferia da de jazida pelo fato de eventualmente apresentar terra e outros elementos transportados pela água, daí este autor também sugerir a sua lavagem. Esta informação entra em contradição com outras já mencionadas, pois a presença de terra foi indicada na areia de mar. Por outro lado, o mesmo 
autor acrescentou que os grãos das areias fluviais ficavam mais arredondados devido ao movimento das correntes, o que ainda não havia sido abordado em outros textos, e realmente reflete a realidade. Quanto às suas recomendações para as areias de jazida, o autor concordou plenamente com os ensinamentos de Vitrúvio ${ }^{56}$. Em La science des ingenieurs, da autoria de Belidor ${ }^{57}$, e no texto Architecture militaire, atribuído a Cormontaigne ${ }^{58}$, as indicações foram mais específicas, pois prescreveram dois tipos de areia: grossa, para alvenaria de pedra, e fina, para cantaria e alvenaria de tijolos.

Na opinião de D'Aviler, tinha-se que:

[...] a melhor areia é aquela de rio que é arenosa: em seguida, a areia vermelha ou branca, mas que tem o grão mais grosso; e enfim a areia preta de jazida. É necessário sobretudo observar que a mais seca, que se une menos a tudo o que toca, é a mais adequada para construir ${ }^{59}$.

No texto Principii di Architettura civile, no entanto, informou-se que, dentre os tipos de areia conhecidos - de jazida, fluvial e de mar - embora o costume fosse dizer, genericamente, que a areia de jazida era a melhor, as demais também eram boas, se convenientemente utilizadas ${ }^{60}$.

É bem verdade que algumas pessoas defendem, acertadamente, hoje em dia, que, em princípio, todos os materiais de construção são bons. Basta sabê-los usar de maneira adequada ${ }^{61}$, por vezes criando detalhes de projeto que venham a colaborar com o seu bom desempenho. O que é preciso é exatamente que o profissional tenha lucidez, competência e perspicácia para saber usá-lo, de modo a propiciar-lhe a maior durabilidade possível, o que levará a uma maior longevidade da obra.

$\mathrm{Na}$ realidade, é difícil dar-se uma regra genérica para os materiais produzidos pela natureza, já que nem sempre são iguais. As características importantes que devem ser identificadas nas areias são a granulometria do material (que tem que ser adequada à finalidade ao qual se destina), a ausência de impurezas (tanto orgânicas, quanto inorgânicas), a composição mineralógica do material, a massa unitária e o coeficiente de inchamento, para que não se comporte de maneira imprevista quando utilizado na confecção das argamassas. No entanto, mesmo não tendo a noção correta disto, muitos dos antigos autores indicaram, intuitivamente, a necessidade de testar-se as areias, assim como também 
recomendaram que se devia fazer o mesmo com a cal e com outros materiais de construção. Isto claramente demonstra que tinham idéia de que suas propriedades variavam dependendo do material disponível.

Quanto ao emprego de areia marinha, foi julgado impróprio no texto atribuído a Fremin. A justificativa para este fato foi dada com base em experiências feitas por profissionais da sua época, tidos como peritos, que haviam concluído que os sais eram inconvenientes por não permitirem uma boa combinação com a cal e reduzirem o seu vigor, devendo ser expurgados, e que a areia de mar era constituída principalmente por grãos finos $^{62}$. Esta opinião foi compartilhada por J. F. Blondel, em finais do mesmo século63.

Atualmente, na Bahia, a areia de rio é sempre que possível empregada, desde que seja retirada de certa distância da foz, quando o rio desagua no mar, para que não contenha sais solúveis, e não apresente muitos resíduos orgânicos. Em Salvador, por exemplo, como a areia de jazida apresenta granulometria muito fina, a de rio é recomendada. Até poucos anos atrás, a areia fluvial utilizada na construção local provinha da dragagem do Rio Paraguaçu, rio perene localizado no Recôncavo Baiano, cujas margens foram ocupadas desde o primeiro século da colonização portuguesa ${ }^{64}$; só que por questões ecológicas a exploração foi suspensa e geralmente hoje as areias que abastecem a capital do Estado da Bahia provêm de jazidas de Camaçari, município da Região Metropolitana.

No entanto, também em Salvador, muito recentemente, eram verificadas explorações clandestinas das muitas dunas existentes ao norte da cidade, formadas por areia de granulometria muito fina, e que eram comercializadas sem ao menos serem lavadas, para uso em argamassas feitas com cimento tipo Portland. Assim sendo, podem ser verificados, em algumas construções, problemas decorrentes da presença de doses maciças de cloreto de sódio dentro do material. Hoje isto não mais ocorre com tanta freqüência pelo fato da região ser protegida por lei.

Félibien, autor que escreveu pouco sobre areia, repetiu mais uma vez as indicações do mestre Vitrúvio, com quem concordou, inclusive, quanto à areia de rio ser a melhor para uso em estuque ${ }^{65}$.

Vitrúvio ensinou que, com relação à cor, os tipos existentes de areia que se prestavam a uso em argamassas apresentavam tonalidades preta, cinza, vermelha e carbúnculo; Faventinus omitiu o tipo cinza e Palladius 
Rutilius, o termo carbúnculo, mas este último autor foi o primeiro a indicar que a areia vermelha era a melhor, seguida pela cinza e por fim a preta. Hugh Plommer estranhou o fato de Faventinus ter omitido a areia cinza, que teria sido utilizada mesmo antes do período de Augusto ${ }^{66}$. Scamozzi, entretanto, foi o primeiro, dentre os autores consultados, que indicou que as areias geralmente se apresentavam como uma mistura de grãos de várias cores $^{67}$. Os outros, de maneira geral, mencionavam areias de cores específicas. No texto atribuível a Milizia, por exemplo, foi indicado que as areias fluviais poderiam ter coloração amarela, vermelha ou branca ${ }^{68}$. Ou seja, as cores também variavam.

De maneira geral não é feita, explicitamente, nos textos antigos, alusão à escolha do tipo de areia tomando-se por base a granulometria. Os autores normalmente mencionavam areia de jazida, de rio ${ }^{69}$ ou de mar. No texto da autoria do mestre de obras Valério de Oliveira, no entanto, ao ser recomendado o traço de uma argamassa, ficou implícita a noção de que se deveria procurar utilizar areias de determinado tamanho de grão, o que, na prática, poderia ser feito baseando-se em material de proveniência conhecida. Por exemplo, em seu texto, notou-se que as areias sugeridas não deveriam ser finas, o que consistia em uma boa indicação, daí a sugestão para uso da areia de Penha de França ou do Alfeite:

Para os fasquiados a prumo, ou tectos, em que he necessário fazer cabeça pela parte de cima, tome-se area branca, e viva ${ }^{70}$, como dizem os Authores, que ha de ter o grão gordo da Penha de França, ou do Alfeite, tirada da vea, e não da praya salgadiça, misturada com rolão do pó de pedra, péga bem na madeira, e faz boa maça com bastante cortimento, e cal bastante, he muito forte, e duravel11.

Certos autores, como Briseux, indicaram o uso de areias com grãos médios, sugerindo o peneiramento do material para a retirada eventual de material grosso ${ }^{72}$. Belidor também mostrou-se favorável ao peneiramento, sendo que recomendou o uso dos grãos finos. Isto foi o que se constatou, por exemplo, nas especificações para a cisterna da igreja paroquial de Calais, apresentada em um de seus livros ${ }^{73}$.

Belidor, inclusive, informou que a cor não tinha a menor influência na qualidade da areia, só o tamanho do seu grão ${ }^{74}$. Pode-se notar que, pelo menos, de maneira geral, eram consideradas areias grossas e finas como adequadas para finalidades específicas. 
Charles-Antoine Jombert também declarou que a cor não influía na qualidade das areias, mas que existiam tipos diferentes, uns melhores do que os outros, sendo cada um deles indicado para uma obra de determinada natureza ${ }^{75}$.

Ao dar esclarecimentos sobre as argamassas de revestimento outrora existentes em Lisboa, Vitor Santos falou em uso de areia de emboço e areia fina do rio ${ }^{76}$. Em contraposição à que era branca, com "o grão gordo da Penha de França ou do Alfeite", mencionada por Valério Oliveira.

Já é visível, pois, nos textos antigos, uma certa preocupação com a granulometria do material, embora de maneira empírica e sem fundamentação clara.

Quanto ao tato, grande parte dos autores recomendou que as areias deviam ser ásperas, como sugeriu Vitrúvio. Jombert, por exemplo, ao descrever a areia de jazida, disse que aquela mais áspera ${ }^{77}$ era a melhor - ou seja, aquela que não era muito fina -, no que concordou com Vitrúvio e com a grande maioria dos autores consultados. Jombert indicou, também, que no caso de ser usada uma areia branca, a boa devia ser rempli de petitts cailloux brutes \& opaques semblables à du gravier ou à des petits morceaux de pierre ${ }^{78}$.

Philibert de l'Orme informou que a escolha da areia a ser utilizada na construção dependia do tipo de obra a que ela se destinasse, o que é correto, sob o ponto de vista atual. Além disto, este mesmo autor mencionou a existência de areias tipos macho e fêmea, mas não forneceu maiores comentários a esse respeito ${ }^{79}$.

Foram poucos os autores que compartilharam da opinião acerca da existência de areia macho e areia fêmea. Belidor foi um deles ${ }^{80}$. Talvez esta terminologia tenha sido apenas uma forma que se criou para distinguir dois tipos de areias que aparentemente se diferenciavam pela coloração e pela uniformidade dos grãos, como indicou J. F. Blondel ao mencionar os tipos de areia existentes: de rio (amarela, vermelha e branca); de jazida (marrom escura, a macho com cor escura e uniforme, e a fêmea de cor pálida e desigual); do mar (mais fina e contendo sais, daí imprópria para uso na construção) ${ }^{81}$.

Como era de se esperar, no que diz respeito às características e propriedades das areias, há contradições entre o pensamento dos diversos autores, pois alguns julgavam ser a areia de rio melhor do que a de jazida, 
outros, o inverso; foram também encontradas diferenças entre as colorações disponíveis. No entanto, era praticamente aceito que a areia do mar só devia ser usada caso não se tivesse possibilidades do emprego de outra, e mesmo assim se fosse bem lavada, de modo a retirar-se-lhe os sais. O problema é que antigamente, como inclusive ainda ocorre, as areias eram eventualmente utilizadas sem lavagem, não por desconhecimento dos problemas que causariam, mas por comodismo, economia ou descuido dos responsáveis pela construção, o que acarretaria seguramente em problemas à obra após a sua conclusão.

J. F. Blondel sugeriu ainda, caso não houvesse disponibilidade de areia no local onde se desejasse construir, que fossem feitas bolas de terra de consistência intermediária entre as argilas e as areias, capazes de reter umidade por um longo tempo ${ }^{82}$. Estas bolas deveriam ser levadas a cozimento e depois desfeitas, usando-se o material pulverizado resultante em lugar da areia. Isto produziria, no seu entender, uma argamassa excelente, pois os problemas decorrentes da má qualidade da areia seriam compensados desta maneira ${ }^{83}$.

\section{Cuidados de utilização}

Notou-se, com freqüência, na bibliografia consultada, a recomendação da utilização de areias secas na confecção de argamassas. Não pelo fato da água nelas presente interferir na dosagem da argamassa, por ocasionar o seu inchamento, o que, sabe-se hoje, levaria a uma alteração do volume, mas sim porque a água atenuaria os sais que a compunham, "apagaria o seu fogo"84 e a impediria de penetrar nas pedras ${ }^{85}$.

Tal afirmação errônea foi mais uma explicação transcendental encontrada para justificar um fato que não se conseguia entender corretamente, na época. Justificava, mas não explicava o que realmente acontecia.

Apesar de recomendar a utilização de areias secas, os citados textos, entretanto, não mencionaram como secá-las, nem como verificar se realmente estavam secas. Existem até mesmo, em alguns destes textos, como nos de Belidor ${ }^{86}$ e de J. F. Blonde ${ }^{87}$, tabelas onde foram indicadas as massas unitárias de areias de rio, de jazida e de mar. Só que não se sabe em que condições estes materiais foram avaliados. 
Atualmente, por ocasião da dosagem de argamassas e concretos, costuma-se avaliar, em laboratório, o teor de umidade apresentado pelos agregados miúdos, de modo que seja possível a reprodução fiel do traço desejado, quando na obra. Isto porque o inchamento desses materiais leva a diferenças nas quantidades utilizadas, caso sejam efetuadas as medições em volume úmido, o que normalmente ocorre.

Jean-Baptiste Bullet (1667-1737) recomendou, sinteticamente, que a melhor areia deveria ser limpa e isenta de terra, com grãos de tamanho médio e que estivesse seca, pois nesta condição os poros não estariam cheios de água, de modo que a cal poderia aderir melhor à mesma ${ }^{88}$, o que foi repetido por Briseux ${ }^{89}$. Apesar dos agregados miúdos apresentarem alguma porosidade, possivelmente a água à qual Bullet e Briseux se referiam era aquela que aderia à superfície dos grãos da areia, e que provoca o seu inchamento.

Vitrúvio recomendou cuidado com a utilização de areia de jazida no sentido que não fosse deixada ao relento muito tempo, para não se degradar por ação das intempéries ${ }^{90}$. Briseux ainda indicou, de modo semelhante a Vitrúvio, que a areia destinada a reboco não devia ser utilizada logo após escavada, pois sua rápida secagem levaria ao aparecimento de fissuras; e que se o destino do material fosse a construção de paredes, não devia ser deixado por muito tempo sofrendo a ação do meio ambiente, para não terminar por se transformar em terra ${ }^{91}$.

Talvez alguns autores antigos assim pensassem porque a areia, depois de um longo período de exposição, ficava muito misturada com matérias orgânicas e outras impurezas, o que se podia constatar pela aparência do material ao natural ou dentro d'água, pela sua coloração e pelo seu cheiro. Conseqüentemente, ficaria imprestável à construção.

A questão das impurezas das areias foi levantada por Alberti92, Belidor $^{93}$ e Jombert ${ }^{94}$, por exemplo, que sugeriram, para a verificação da qualidade da areia, a colocação de uma amostra dentro de um recipiente com água e, após agitação, a observação do comportamento do material: se a água ficasse escura e borbulhante, a areia era gorda e terrosa; se permanecesse limpa, era pura e adequada ao uso.

Quando a água fica escura e apresenta bolhas é porque a areia contém certamente muita matéria orgânica, o que a torna realmente inadequada para uso nas argamassas, de modo que o teste prático 
sugerido pelos diversos autores realmente servia para a identificação de material de má qualidade. Hoje em dia têm-se condições de, através de ensaios simples, verificar a presença de matéria orgânica na areia, e por meio de ensaios mais apurados, quantificar o seu percentual ${ }^{95}$.

Com relação à areia marinha, seu uso só era indicado na falta de outra, pois acarretaria em lentidão de secagem das paredes, além do fato das argamassas com ela elaboradas não suportarem grandes cargas e levarem ao aparecimento de manchas, por higroscopicidade. $\mathrm{O}$ arquiteto francês Louis Savot (Ca. 1579-1640), por exemplo, nem a incluía dentre os tipos existentes, o que denota que alguns autores realmente não a aprovavam como material de construção ${ }^{96}$. Sanvitali concordou que tal tipo de areia podia ser usado em última instância, porém bem lavado para a retirada dos sais solúveis ${ }^{97}$. No texto atribuído a Milizia também encontrou-se a afirmação que a areia do mar era boa para uso se completamente livre, por meio de lavagem, dos sais solúveis nela presentes $^{98}$, principalmente se a intenção fosse misturá-la com cal forte e gorda ${ }^{99}$.

D'Aviler descreveu as areias, de maneira genérica, e disse qual era a melhor segundo sua proveniência e coloração. Além disto, recomendou que se devia usar a areia mais seca, que fosse menos untuosa (indício de que conteria argila), e a que apresentasse um tamanho maior de grão ${ }^{100}$. Para este autor não se devia, simplesmente, levar em consideração a cor do material quando da sua escolha, o que é correto, mas sim outras características, também importantes.

O padre Vasconcellos, ao descrever a utilização da areia, reprovou o uso da fluvial, alegando que não apresentava bons resultados, pois ficava sempre úmida ${ }^{101}$. Indicação estranha, pois tal fato não se constata nas construções executadas com este material, atualmente. Talvez a informação tenha sido decorrente de alguma observação feita em obras nas quais tenha sido usada areia de rio proveniente de uma zona próxima ao mar, como acontecia da areia do Tejo nas imediações de Lisboa.

A presença de sal na argamassa faz com que, por higroscopia, a umidade do ar seja absorvida e a superfície argamassada apresente manchas escuras de molhação. A água, então, pode ensejar o aparecimento de microorganismos, que se proliferam quando encontram condições favoráveis, ou manchas esbranquiçadas decorrentes da 
cristalização salina. Estas, por sua vez, em se desenvolvendo, podem até mesmo levar à escamação da parede e ao descolamento das camadas mais externas do revestimento, o que ocorre devido ao aumento de volume dos cristais de sal dentro da porosidade do material.

Além disto, o umedecimento das paredes ocasiona a degradação de outros materiais de construção contíguos a elas, como madeiras e tijolos, por exemplo. Apesar do uso de areia do mar ainda ser condenado pelas razões supramencionadas, hoje ainda são comuns problemas oriundos do seu emprego, em desobediência às normas que regem a construção civil, no Brasil.

Nas cidades litorâneas da costa brasileira pode-se verificar, com relativa freqüência, que não apenas as populações de baixa renda utilizam esse material nas construções de suas casas, como também pessoas de classes mais abastadas, por adquirirem material proveniente de dunas na mão de vendedores que as comercializam de maneira ilícita.

Diogo Vellozo, ao mencionar o uso da areia do mar, citou o que Alberti pensava sobre o fato desse tipo de areia não ser bem empregada em paredes que resguardão o Sul, he melhor porem naquellas que resguardão o Norte ${ }^{102}$.

Deduz-se que a opinião de Alberti era válida no caso da orientação ser correspondente ao vento mais úmido na região, o que levaria a um umedecimento mais rápido da parede. No entanto, o que Diogo Vellozo fez foi apenas dar uma demonstração de erudição ao citar Alberti, pois para assumir tal posição como válida para as terras pernambucanas seria preciso comparar os ventos dominantes na Itália com aqueles do nordeste do Brasil, o que não foi feito. Vellozo repetiu, simplesmente, o que leu nos importantes tratadistas europeus que citou (Vitrúvio, Scamozzi, Palladio, entre outros), o que era praxe, séculos atrás. Mas não verificou, ou ressalvou, a validade da informação para o local onde trabalhava. Teria sido mais interessante, ao invés da simples reprodução de idéias de outras pessoas, que tivesse sido feito o julgamento crítico dos seus textos.

\section{Notas}

1 VITRUVIO, Marco Lucio. Los diez libros de arquitectura, tradução, prólogo e notas de Agustín Blánquez. Barcelona: Iberia, 1955. L. II, Cap. IV, p. 42.

2 BRANCA, Giovanni. Manuale d'architettura, comentários e acréscimos de Giovanni Soli, $5^{\mathrm{a}}$ ed. Modena: Soc. Tipográfica, 1789. L. I, Cap. IV, p. 8. 
${ }^{3}$ BRISEUX, Charles Etienne. L'art de bâtir des maisons de campagne. Paris: Prault Pere, 1743. v. II, Parte II, Cap. III, p. 39.

${ }^{4}$ GURRIERI, Francesco. «Piero Sanpaolesi, il restauro come scienza», Piero Sanpaolesi: il restauro, dai principi alle tecniche, Catálogo da VI Assembleia Geral do ICOMOS, Florença, Fac. de Architettura dell'Università degli Studi di Firenze/Regione Toscana (Dip. Istr. e Cultura), 1981, p. 7-12. p. 12.

${ }^{5}$ [MILIZIA, Francesco], Principii di architettura civile, Bassano, Remondini di Venezia, 1785. t. III, Parte III, L. I, Cap. IV, p. 35. - Un ammasso di particelle disgiunte, scabrose, rigide, cristalline, impenetrabile dall'acqua, indissolubili dall'acqua-forte, scintillante alle percosse dell'acciaro, resistente al fuoco, e vetrificabili.

${ }^{6} / d$., ibid., t. III, Parte III, L. I, Cap. IV, p. 41.

${ }^{7}$ NBR-9777 - Agregados - Determinação da absorção de água em agregados miúdos. RJ, ABNT, Março/1987.

8 SARAIVA, F. R. dos Santos, Novissimo diccionario latino-portuguez. Rio de Janeiro, Garnier, s.d. p. 183 - Carbunculus - Vitr. areia avermelhada.

${ }^{9}$ ALBERTI, Leon Battista. De re ædificatoria (Florença, 1495), trad. de Giovanni Orlandi, introd. e notas de P. Portoghesi, ed. bilingüe latim/italiano, L'archittetura, Milão, II Polifilo, 1966. v. I, L. II, Cap. XII, p.160, Nota 1. - Esta definição aparentemente entra em contradição com a de Saraiva, já referida (areia avermelhada).

10 /d., ibid., v. I, L. II, Cap. XII, p. 160.

${ }^{11}$ SCAMOZZI, Vincenzo. L'idea della architettura universale (Veneza, V. Scamozzi, 1615), fac-símile, Sala Bolognese, Arnaldo Forni, 1982. v. II, Parte II, L. VII, Cap. XX, p. 232.

12 [FREMIN]. Memoires critiques d'architecture. Paris: Charles Saugrain, 1702, p. 114/115.

${ }^{13} / d$., loc. cit.

${ }^{14}$ Id., ibid., p. 113. - Sur cela même je conçois qu'où les terres sont humides, le sable que s'y trouve est plus doux, parce que l'humidité attendrissant tous les êtres oû elle sejourne, les sables qui sont dans ces lieux-là y ont moins de sels, \& par consequent moins d'arridité $\&$ de seicheresse.

${ }^{15} \mathrm{~A}$ areia.

${ }^{16}$ EÇA, Mathias Ayres Ramos da Sylva de. Problema de architectura civil. Lisboa, Antonio Rodrigues Galhardo, 1777. Parte II, Cap. II, p. 7 // NEGREIROS, Jozé Manuel de Carvalho. Jornada pelo Tejo, [Lisboa], Cód. 80 (AHM), 1792. fls. 148.

${ }_{17}$ BLONDEL, Jacques-François, Cours d'architecture, Paris, Desaint, 1777. v. VII, t. V, Cap. V, art. II, p. 185/186. - [...] c'est une espéce de gravier de différentes grosseurs, qui est diaphâne ou opaque, rude, âpre, raboteux, \& sonore, selon la qualité différente des sels dont il est formé, \& des divers terreins où il se trouve.

${ }^{18}$ EÇA, Mathias Ayres Ramos da Sylva de. Problema de architectura civil..., Parte II, Cap. II, p. 7/8 // NEGREIROS, Jozé Manuel de Carvalho. Jornada pelo Tejo..., fls. 148v/149.

${ }^{19}$ EÇA, Mathias Ayres Ramos da Sylva de. Problema de architectura civil..., Parte Il, Index, p. 335.

${ }^{20}$ /d., ibid., Parte I, Cap. III, p. 56 a 62.

${ }^{21} \mathrm{O}$ sol e o sal estão presentes em tudo na natureza.

22 NEGREIROS, Jozé Manuel de Carvalho. Jornada pelo Tejo..., fls. 150. 
${ }^{23}$ NEGREIROS, Jozé Manuel de Carvalho. Jornada pelo Tejo..., fls. 149v.

${ }^{24}$ COUTO, Mattheus do (o Velho). Tractado de architectura, [Lisboa], Cód. F. 7752 (BNL), 1631. L. II, Cap. IX, p. 37 - Na opinião deste autor, a areia de mar poderia ser usada nos maciços das paredes, porém de preferência só em fundações, por causa dos sais nela presentes.

${ }^{25}$ SILVA-NIGRA, Clemente da (D.). Fr. Bernardo de São Bento. Salvador: Tipografia Beneditina, 1950. p. 119.

${ }^{26}$ VELLOZO, Diogo da Sylveyra. Architectura militar. Pernambuco: Cód. 49-III-3 (BAj), 1743. Parte II, Cap. XXV, fls. 221v.

${ }^{27}$ NEGREIROS, Jozé Manuel de Carvalho. Jornada pelo Tejo..., fls. 151v.

${ }^{28} /$ d., ibid., fls. 152.

${ }^{29}$ Destaca-se que, em certas regiões do país, o mesmo material recebe o nome de arenoso, e em Pernambuco, curiosamente é chamado, de maneira vulgar, de "traço".

${ }^{30}$ MORAIS SILVA, António de. Grande dicionário da língua portuguesa, 10ª ed.. Lisboa: Confluência, 1955. v. VIII, p. 467, verbete polme.

${ }^{31}$ BRISEUX, Charles Etienne, L'art de bâtir des maisons de campagne..., v. II, Parte II, Cap. III, p. $40-[. .$.$] petite argille, qui est une terre jaune, sablonneuse, \& un peu grasse. Celle$ qu'on trouve sous la grosse argille, est la meilleure, \& approche le plus du sable: II faut rejetter celle qui se trouve sur la superficie de la terre, \& ne prendre que l'argille qui est au dessous. Cette sorte de terre consume plus de chaux que le sable, \& il faut redoubler son attention, pour en faire du mortier; car étant plus difficile à corroyer, les ouvriers y employent beaucoup d'eau, \& ce mortier mal corroyé n'ayant aucune consistance, se réduit aisément en poudre lorsqu'il est sec.

${ }^{32}$ RODRIGUES, Maria João Madeira; SOUSA, Pedro Fialho de; BONIFÁCIO, Horácio Manuel Pereira. 2. ed. rev.. Vocabulário técnico e crítico de arquitectura. Coimbra, Quimera, 1996. p. 239.

${ }^{33}$ RODRIGUES, Francisco de Assis. Diccionario technico e historico de pintura, esculptura, architectura e gravura. Lisboa: Imprensa Nacional, 1875. p. 335/336.

${ }^{34}$ SANVITALI, Federico (Pe.). Elementi di architettura civile. Brescia: Giammaria Rizzardi, 1745. Parte I, Cap. I, Prop. XII, p. 23/24.

${ }^{35}$ JOMBERT, Charles-Antoine. Architecture moderne. Paris: Ch. A. Jombert, 1764. L. I, Cap. IX, art. III, p. 42.

${ }^{36}$ BLONDEL, Jacques-François. Cours d'architecture..., v. VII, t. V, Cap. V, Art. II, p. 185. Le sable de riviere est le plus estimé pour faire de bon mortier, ayant été battu par l'eau, \& se trouvant par là dégagé de toutes les parties terreuses dont il tire son origine.

${ }^{37}$ RIEGER, Christiano (Pe.), Elementos de toda la architectura civil, Madrid, Joachîn Ibarra, 1763. Parte IV, Cap. I, p. 223/224. - La arena, ni deve ser muy gorda, ni muy sutil, porque la primera no es cómmoda para el trabajo, y menos lo es la segunda, que nunca úne bien con la cal.

${ }^{38}$ Não foi especificado, mas para saber qual a quantidade de partículas terrosas que teriam sido lixiviadas, o material pesado deveria estar seco, tanto antes, quanto depois.

${ }^{39}$ Silte e argila. 
${ }^{40}$ PATTE. Mémoires sur les objets les plus importans de l'architecture. Paris: Rozet, 1769. Cap. III, Art. II, §IV, p. 117.

${ }^{41}$ [MILIZIA, Francesco]. Principii di architettura civile.... T. III, Parte III, L. I, Cap. IV, p. 38.

${ }^{42}$ CARNEIRO, Edison. A cidade do Salvador, $2^{\mathrm{a}}$ ed.. Salvador: Econômico e Administração, s.d. Cap. III, item 7, p. 65.

${ }^{43}$ PALLADIO, Andrea. I quattro libri dell'architettura (Veneza, Dominico de'Franceschi, 1570), fac-símile, Milão, Hoepli, 1968. L. I, Cap. IV, p. 8.

${ }^{44}$ [FREMIN]. Memoires critiques d'architecture..., p. 115/116.

${ }^{45}$ PLOMMER, Hugh. Vitruvius and later Roman building manuals. Cambridge, The University Press, 1973. p. 34.

${ }^{46}$ VASCONCELLOS, Ignacio da Piedade (Pe.). Artefactos symmetriacos, e geometricos..., p. 378.

${ }^{47}$ NEGREIROS, Jozé Manuel de Carvalho. Jornada pelo Tejo..., fls. 143v/144 - Segundo este autor, era necessário [...] prohibirse com penas e castigos rigorosos inalteravelmente executados, que a cál fosse caldeada com agoa salobra ou salgada.

${ }^{48}$ A tradução encontrada para o termo ghiaia foi saibro. Lendo-se o resto da frase, podese concluir que o material deveria ser similar ao definido por Francisco de Assis. - Saibro de tipo mais fino, especialmente de forma poligonal e isento da mistura com a terra.

${ }^{49}$ ALBERTI, Leon Battista. De re ædificatoria, trad. de Giovanni Orlandi..., v. I, L. II, Cap. XII, p. 160.

${ }^{50}$ CATANEO, Pietro. I quattro primi libri di architettura (Veneza, Figliuoli di Aldo, 1554), facsímile, Ridgewood, The Gregg Press Incorporated, 1964. L. II, Cap. IIII, fls. 29. - [...] \& in tutto sono da fuggire quelle rene, che tengono de terra e loto.

${ }^{51}$ MOREIRA, Rafael. Um tratado português de arquitectura do século XVI. Lisboa, Faculdade de Ciências Sociais e Humanas, 1982. Dissertação de mestrado. - Segundo a Nota 27 de Rafael Moreira, era a reprodução praticamente ipsis verbis do capítulo IV, do L. II, de Cataneo.

${ }^{52}$ [RODRIGUES, António]. [Tratado de arquitectura], [Lisboa], Cód. 3675 (BNL), [séc. XVI] Cap. VIII, fls. 19, MOREIRA, Rafael. Um tratado português de arquitectura do século XVI...

${ }^{53}$ VITRUVIO, Marco Lucio. Los diez libros de arquitectura, tradução de Agustín Blánquez..., L. II, Cap. IV, p. 42.

${ }^{54}$ ALBERTI, Leon Battista. De re ædificatoria, trad. de Giovanni Orlandi..., v. I, L. II, Cap. XII, p. 160/162.

${ }^{55}$ PALLADIO, Andrea. I quattro libri dell'architettura..., L. I, Cap. IV, p. 8.

${ }^{56}$ [MILIZIA, Francesco]. Principii di architettura civile..., t. III, Parte III, L. I, Cap. IV, p. 38 a 40.

${ }^{57}$ BELIDOR, Bernard Forest de. La science des ingenieurs. Paris, Claude Jombert, 1729. V. I, L. VI, Cap. III, p. 19/20.

58 [CORMONTAIGNE]. Architecture militaire. Haia, Jean Neaulme et Adrien Moetjens, 1741. Parte I, Cap. XXII, p. 94.

${ }^{59}$ D'AVILER, Augustin Charles. Cours d'architecture, $3^{\text {a }}$ ed., Amsterdam, George Gallet, 1699. v. I, p. 213/214. - [...] la meilleur sable est celuy de riviere qui est graveleux: ensuite le sable rouge ou blanc, mais qui a le grain le plus gros; \& enfin le sable noir de cave. II faut sur 
tout observer que le plus sec, \& qui s'attache le moins à tout ce qu'il touche est le plus propre pour bastir.

60 [MILIZIA, Francesco]. Principii di architettura civile..., t. III, Parte III, L. I, Cap. IV, p. 36.

${ }^{61}$ OLIVEIRA, Mário Mendonça de. «A prancheta, o canteiro e a durabilidade do construído». Revista RUA, Salvador, MAU, 1989. v. II, n. ${ }^{\circ}$ 3, p. 117-131. p. 124.

62 [FREMIN]. Memoires critiques d'architecture..., p.117.

${ }^{63}$ BLONDEL, Jacques-François. Cours d'architecture ..., v. VII, t. V, Cap. V, Art. II, p. 186.

${ }^{64}$ Logo, provavelmente desde então aquela areia deve ter sido, ao menos, empregue naquela região.

${ }^{65}$ FÉLIBIEN, André. Des principes de l'architecture, $3^{a}$ ed., Paris, la Veuve et Jean Baptiste Coignard Fils, 1699. p. 510.

${ }^{66}$ ASHBY. Architecture of ancient Rome. Londres, 1927. p. 32. Apud PLOMMER, Hugh, Vitruvius and later Roman building manuals..., p. 34 e 35.

${ }^{67}$ SCAMOZZI, Vincenzo. L'idea della architettura universale..., Cap. XXII, p. 238.

${ }^{68}$ [MILIZIA, Francesco]. Principii di architettura civile..., t. III, Parte III, L. I, Cap. IV, p. 39.

${ }^{69}$ Quanto ao uso da areia de rio, chama-se a atenção que, em sendo tirada das imediações da barra - como acontecia por vezes nas imediações de Lisboa, quando a areia era retirada da barra do Tejo -, deveria conter sais solúveis.

70 SANTOS, Vitor Manuel V. Lopes dos. O sistema construtivo pombalino em Lisboa. Lisboa, Fac. de Arquitectura da Universidade Técnica, 1994. Tese de doutorado. v. I, Parte I, Cap. IV, item 1, p. 55 - Conforme este autor, tal areia seria areia de emboço.

${ }^{71}$ OLIVEIRA, Valério Martins de. Advertencias aos modernos. Lisboa, Antonio da Sylva, 1748. p. 89 (grafia original) - Como curiosidade, na mesma citação nota-se que o autor repudiou o uso de material contaminado com sal marinho, como outros também o fizeram.

${ }^{72}$ BRISEUX, Charles Etienne. L'art de bâtir des maisons de campagne..., v. II, Parte II, Cap. III, p. 36.

${ }^{73}$ BELIDOR, Bernard Forest de. La science des ingenieurs..., v. I, L. VI, p. 76 - I/ sera du plus pur qui se trouvera dans le pays, sans mélange, \& passé à la claye, laquelle sera fort fine, afin qu'il ne s'y trouve point de gallets // Ela será da mais pura que se encontrar no país, sem mistura e, passada na peneira, será bastante fina, de modo que nela não se encontrem pedaços de calhaus.

${ }^{74}$ /d., ibid., v. I, L. III, Cap. IV, p. 10.

${ }^{75}$ JOMBERT, Charles-Antoine. Architecture moderne..., L. I, Cap. IX, art. I, p. 41.

${ }^{76}$ SANTOS, Vitor Manuel V. Lopes dos. O sistema construtivo pombalino em Lisboa..., v. I, Parte I, p. 49 e v. I, Parte II, p. 22.

77 [...] celui qui a des grains comme de petits cailloux \& qui fait du bruit quand on le manie [...]. - aquela que tem os grãos como pequenos seixos e que faz barulho quando a manejamos.

78 JOMBERT, Charles-Antoine. Architecture moderne..., L. I, Cap. IX, art. II, p. 41/42. - [...] cheia de pequenos seixos ásperos e opacos, semelhantes ao pedregulho ou a pequenos pedaços de pedra. 
${ }^{79}$ DE L'ORME, Philibert. Le premier tome de l'architecture (Paris, Frederic Morel, 1567), fac-símile. Traités d'architecture. Paris, Léonce Laget, 1988. L. I, Cap. XVII, fls. 28.

${ }^{80}$ BELIDOR, Bernard Forest de. Dictionnaire portatif de l'ingénieur. Paris, Charles-Antoine Jombert, 1755. p. 281.

${ }^{81}$ BLONDEL, Jacques-François. Cours d'architecture..., v. VII, t. V, Cap. V, Art. II, p. 185.

${ }^{2}$ DUHAMEL DU MONCEAU. Henri-Louis. De l'exploitation des bois, Paris, H. L. Guerin \& L. F. Delatour, 1764. Parte I, L. I, art. IV, p. 56.

${ }^{83}$ BLONDEL, Jacques-François. Cours d'architecture..., v. VII, t. V, Cap. V, art. II, p. 187.

${ }^{84}$ Possivelmente, esta expressão deveria significar que se a areia estivesse molhada, a água reduziria a sua capacidade de reagir. No entanto, sabe-se, atualmente, que a areia, de maneira geral, não reage na mistura.

${ }^{85}$ [FREMIN]. Memoires critiques d'architecture..., p. 118/119.

${ }^{86}$ BELIDOR, Bernard Forest de. La science des ingenieurs..., v. I, L. III, Cap. IV, p. 25.

${ }^{87}$ BLONDEL, Jacques-François. Cours d'architecture...., v. VIII, t. VI, Cap. I, Art. VIII, p. 41.

${ }^{88}$ BULLET, Jean-Baptiste. L'architecture pratique. Paris, Ch. J. B. Delespine \& Jean-Th. Herissant, 1741. p. 160.

${ }^{89}$ BRISEUX, Charles Etienne. L'art de bâtir des maisons de campagne..., v. II, Parte II, Cap. III, p. 39.

$9^{0}$ VITRUVIO, Marco Lucio. Los diez libros de arquitectura, tradução de Agustín Blánquez..., L. II, Cap. IV, p. 43.

${ }^{91}$ BRISEUX, Charles Etienne. L'art de bâtir des maisons de campagne..., v. II, Parte II, Cap. III, p. 40.

${ }^{92}$ ALBERTI, Leon Battista. De re ædificatoria, trad. de Giovanni Orlandi..., v. I, L. II, Cap. XII, p. 160.

${ }^{93}$ BELIDOR, Bernard Forest de. La science des ingenieurs..., L. III, Cap. IV, p. 11.

${ }^{94}$ JOMBERT, Charles-Antoine. Architecture moderne..., L. I, Cap. IX, art. II, p. 42.

${ }^{95}$ NBR-7220 - Agregados - Determinação de impurezas orgânicas húmicas em agregado miúdo. Rio de Janeiro, ABNT, Ago./1987.

${ }^{96}$ SAVOT, Louis. L'architecture françoise des batiments particulieres. Paris, 1624. Cap. XXXVIII, p. 264.

${ }^{97}$ SANVITALI, Federico (Pe.). Elementi di architettura civile..., Parte I, Cap. I, Prop. XII, p. 24

98 Vitrúvio não fez referência alguma à conveniência da lavagem da areia de mar, de modo a minorar-se os problemas decorrentes da presença de sais solúveis, especialmente cloretos, o que foi notado em outros textos.

99 [MILIZIA, Francesco]. Principii di architettura civile..., t. III, Parte III, L. I, Cap. IV, p. 41.

${ }^{100}$ D'AVILER, Augustin Charles. Cours d'architecture..., v. I, p. 213/214.

${ }^{101}$ VASCONCELLOS, Ignacio da Piedade (Pe.). Artefactos symmetriacos, e geometricos..., L. IV, Cap. XVI, p. 378.

102 VELLOZO, Diogo da Sylveyra. Architectura militar..., Parte II, Cap. XXV, fls. 222. 
Além da cal e da areia, materiais utilizados na maioria das argamassas antigas estudadas, vários outros constituintes foram eventualmente a eles adicionados, ou adotados em seu lugar. Como exemplo, citam-se os seguintes: pozolana, cerâmica moída, pó de mármore, terraços fluviais do Baixo Reno, cinzas de Tournai, carvão, sangue, suco de frutas ou de vegetais, leite, queijo, palha, pêlo animal, cerveja, arroz, açafrão, açúcar, resinas, óleos, sebo, vinho, urina, clara de ovo, algodão, amido, banha de porco, cabelo, excremento, fibras, gesso ${ }^{1}$.

Belidor, por exemplo, sugeriu como ingrediente opcional na confecção de argamassas hidráulicas, pó oriundo da pulverização de pedaços de vasos e mache-fer ${ }^{2}$ proveniente de hulha queimada associada a pó de material cerâmico e pedra de mó de moinho e calcário ${ }^{3}$.

Pelos exemplos dados, pode-se verificar que tanto adições orgânicas, quanto inorgânicas, foram utilizadas no decorrer dos séculos. Cada uma, entretanto, tinha uma função específica.

Já que não é possível relacionar todos os exemplos interessantes encontrados na bibliografia, nem tampouco discorrer sobre todos os aditivos supramencionados, serão tecidas, neste capítulo, considerações apenas acerca de alguns tipos de pozolanas.

De maneira geral, "todos os minerais que, por aquecimento, originam a perda de iões $\mathrm{OH}^{-}$da sua rede cristalina, e que, depois dessa perda, são susceptíveis de mudarem de rede, mostrarão comportamento pozolânico"4. 
Logo, o universo dos materiais considerados como pozolanas é muito amplo. Norman Davey, por exemplo, subdividiu as pozolanas em dois grandes grupos, a saber ${ }^{5}$ :

- Pozolanas naturais:

Pozolanas italianas;

Terra de Santorim (Grécia);

Trass (Alemanha);

Cinzas vulcânicas do Japão, Portugal, França e Espanha;

Terras diatomáceas, diatomitas, trípoli, calcário silicoso decomposto, farinha fóssil.

- Pozolanas artificiais:

Argila xistosa queimada, diatomita e pumicita queimadas, cerâmica queimada;

Cerâmica pulverizada e fragmentos cerâmicos;

Algumas escórias.

Alberto de Castro e Antônio Lima (séc. XX), por sua vez, deram a seguinte definição:

Materiais naturais, artificiais ou certos subprodutos industriais de natureza siliciosa, aluminosa que revelam a propriedade de se combinarem, à temperatura ordinária, e em presença da água, com o hidróxido de cálcio e outros componentes do cimento hidratado, originando compostos de grande estabilidade química na água e com propriedades aglutinantes 6 .

Neste capítulo, serão dadas informações sobre pozolanas italianas, pó cerâmico, terraços fluviais do Baixo Reno e cinzas de Tournai, ingredientes dos quais se obteve maiores detalhes nas fontes consultadas.

\section{Pozolanas italianas}

A primeira reserva natural de pozolana descoberta no mundo encontrava-se em Pozzuoli, nas imediações da atual cidade de Nápoles (Itália). Por esta razão, Vitrúvio referiu-se ao material como "pó de Pozzuoli", e caracterizou-o como uma terra especial daquela região, que produzia 
efeitos maravilhosos quando misturada com cal e pedra moída ${ }^{7}$. Os livros consultados ratificam isto.

Material de origem vulcânica, a pozolana confere hidraulicidade às argamassas, o que também é amplamente aceito pelos autores estudados. Esta propriedade propicia sua utilização em locais úmidos ou alagadiços. Por isto, era recomendada pelo mestre romano, e por outros que the sucederam, na construção de portos. Não obstante, o material pode ser utilizado em locais secos, adquirindo boa resistência após o endurecimento, conforme igualmente evidenciado nos textos analisados, desde que durante o processo a argamassa seja mantida úmida. As argamassas pozolânicas endurecem exatamente devido à reação cal-pozolana que ocorre em presença de água ${ }^{8}$. Isto porque o material apresenta elevada porosidade, o que favorece a reação entre a pozolana e a cal extinta, com a formação de compostos hidráulicos.

Constatou-se, através da bibliografia, que a origem das pozolanas foi atribuída à ação de fogos subterrâneos, sem que fosse indicada uma ligação direta entre o material e a atividade vulcânica, de maneira geral.

No texto atribuível a Milizia, no qual a pozolana foi considerada como a areia mais adequada para as construções ${ }^{9}$, tem-se que Vitrúvio, conforme Filandro ${ }^{10}$, teria dito que:

[...] A pozolana é apenas uma mistura de terra com tufo, com betume e com qualquer outra parte sulfúrea, mistura preparada por fogos subterrâneos ${ }^{11}$.

Na tradução de Blánquez, a descrição dada por Vitrúvio não foi esta. Pelo que parece, ocorreu algum problema com algumas das traduções, ou com a interpretação do texto. O que se tem em idioma espanhol é o seguinte:

[...] nas entranhas daqueles montes há terra e numerosas fontes de água quente, que não existiriam se não estivessem debaixo de fortíssimos fogos, alimentados ou por enxofre ou por alúmen ou por betume. Este fogo e estas chamas, ao penetrar e atuar através dos meandros e veias da terra, a fazem leve, e o tufo (ou a "toba") que ali existe é isento de umidade ${ }^{12}$.

Pelo que se pode deduzir do texto traduzido por Agustín Blánquez, o betume, o enxofre ou o alúmen serviriam apenas para alimentar o fogo 
subterrâneo, e não estariam presentes na composição da pozolana, como parece pela indicação dada no texto atribuível a Milizia.

Para Gioseffe Viola Zanini, a pozolana consistia em um tipo de terra queimada pelo fogo $^{13}$; Belidor informou que a pozolana, material considerado como um pó, era constituída por terra e tufa queimadas pelos fogos subterrâneos que saíam das montanhas, nas proximidades dos locais onde era tirada, daí sua admirável propriedade de endurecer debaixo da água ou em presença de umidade ${ }^{14}$. Ambos os autores foram, pois, favoráveis à origem deste material ser decorrente da sua queima por fogos subterrâneos.

Negreiros foi mais específico: considerou a pozolana como uma espécie de areia e destacou que era um material vitrificado, daí ser resistente à umidade e secar com rapidez:

[...] a dita areia chamada pussolana [sic], he uma materia vitrina, e porisso rezistente ás humidades e muito desecante, que, segundo o pensar de muitos, soffreu a acção dos antigos vulcanos ${ }^{15}$.

Com relação às reservas naturais do produto, durante muito tempo, a única fonte conhecida de pozolana foi, aparentemente, a indicada por Vitrúvio, em Pozzuoli, imediações de Nápoles (Itália).

Muitos autores, ao discorrerem sobre as características do material, mencionaram o fato claramente, o que é ora exemplificado através da transcrição de passagens retiradas dos textos dos autores listados a seguir:

- Plínio - Existem ainda, além destas, outras espécies de terra: e quem não se maravilharia, que a pior parte dessa, e por isto chamada pó, nas colinas de Pozzuoli, servisse para consertos mesmo em presença da água do mar? Tal pó, tão logo é imerso, torna-se pedra única, que a cada dia se faz mais inexpugnável e mais forte, principalmente misturando-se com cal de Cuma $^{16}$;

- Alberti - Na zona de Pozzuoli há em abundância um tipo de pó que misturado à água de mar endurece como pedra ${ }^{17}$;

- Cataneo - O pó de pozolana da região em torno ao monte Vesúvio tem a vantagem de todas as areias: pois, sendo de tufo seco queimado, tendo-lhe saído o licor, torna-se mais leve, e melhor: e ao misturá-la depois com cal, e com água, recebendo imediatamente 
o licor, fazem corpo junto; e imediatamente recebendo o humor, dão pega rápida às construções, às quais não só o mar e a força das águas não podem ser nocivos, mas endurece de tal maneira a fábrica, principalmente a parte sob a água, que a parede torna-se pedra única, e isto não é maravilha: quando querem, colocam no mar a dita pozolana e, por si só torna-se pedra $[\ldots]^{18}$.

\section{J. F. Blondel considerou a pozolana como:}

[...] matéria betuminosa, que se encontra nas imediações do Vesúvio, a qual é composta de partes metálicas e de pequenos cristais muito ásperos ao toque: misturando esta pozolana com cal de mármore ou de conchas, resulta em uma argamassa que a água torna mais firme, ao invés de a destruir ${ }^{19}$.

Não existe, a priori, uma razão para ser misturado com pozolana apenas cal de mármore ou de conchas. Por outro lado, da análise das citações de Alberti e Cataneo anteriormente transcritas, verificou-se que a pozolana, sozinha, tinha a capacidade de endurecer na água. Nos demais textos, foi indicada a mistura do material com areia, ou com areia e cal.

É curiosa a caracterização do material como uma matéria betuminosa, o que deve ter ocorrido exatamente por causa da sua propriedade de resistir à ação da água.

Quanto à descoberta de novas jazidas, além daquela das imediações do Vesúvio, sabe-se que, posteriormente, pozolanas de outras proveniências foram utilizadas em construções, não apenas na Península Itálica, mas em outros países, o que pode ser notado em diversos textos, como naquele atribuível a Milizia:

Vitrúvio, por ver jazidas de pozolana apenas no entorno de Nápoles, quebrou a cabeça para explicar porque em outros locais não existiam: mas em outros locais, existiam; e em Roma, onde vivia Vitrúvio, as jazidas abundavam mais do que em qualquer outro lugar. Impossível que ele não as visse! Talvez ainda não tivessem sido descobertas ${ }^{20}$.

Os textos de Belidor ${ }^{21}$ e Negreiros ${ }^{22}$ também podem ser citados como exemplos do conhecimento de outras jazidas. Na segunda edição do texto de Giovanni Branca, datada de 1718, foi mencionada, por exemplo, a pozolana de Roma ${ }^{23}$. Por outro lado, nesse mesmo texto informou-se que, na falta da pozolana, se devia preparar a argamassa com um material similar: 
[...] pedaços pequenos de peperino de S. Fiorge com certa terra de cor cinza escura, que é cavada em Monte Rotondo em um lugar chamado Rene, ambas as matérias vitrinas e por isso resistentes à umidade, como a pozolana de Roma (matéria também vitrina), e que segundo o parecer de alguns, sofreu a ação de antigos vulcões ${ }^{24}$.

O material citado, que consiste em tufo vulcânico ${ }^{25}$ alterado, apresenta propriedades pozolânicas, embora muito menores do que aquelas das pozolanas oriundas dos tufos vermelhos e cinzas.

No já citado texto atribuível a Milizia, também foi encontrada referência a outro tipo de material de origem vulcânica, similar à pozolana, existente nas imediações do Vesúvio:

Em Nápoles e no seu entorno encontram-se sob a terra muitos estratos de uma certa espécie de pedrinhas similares a pequenas pedraspomes, e um tanto amareladas como pedaços de telhas pulverizados, chamados de rapilli, ou seja, lapilli. Esta matéria também é produzida por vulcões, e faz ótima liga com a cal26.

Este material era possivelmente o mesmo ao qual Scamozzi, conforme Rodolico, havia feito referência, como pode ser verificado através da leitura da passagem a seguir transcrita:

[...] sob os tufos cavam a pozolana de cor branca um pouco esmaecida, e ótima nas argamassas, e sob a pozolana encontram o grapello, ou verdadeiro serepillo (como esses dizem), o qual é uma matéria um tanto amarelada, e como pedacinhos de telhas ou telhas planas moídos: a qual serve para fazer os terraços, e o menor usam para fazer granzolo ao rebocar as paredes. - Grapello e serepillo são nomes dialetais dos locais de extração das pozolanas ${ }^{27}$. (grifos não existentes no original)

Foram encontrados outros pormenores do material consultando-se diretamente o texto de Scamozzi:

Em Nápoles, além de muitos outros locais do reino, cavam uma certa matéria a que chamam grapillo, que a nosso parecer é uma espécie de tufo duro e em bolinhas como avelãs e nozes, e os menores, de cor tendente ao amarelo: onde o mais grosso e o mediano servem para fazer terraços e o menor, para misturar na argamassa para rebocar as paredes; sendo que em ambos os casos propicia excelente pega ${ }^{28}$. (grifo não existente no original)

Possivelmente tal material era a pozolana correspondente ao tufo amarelo napolitano. 
Ao escrever sobre cal, Filarete informou que, segundo a crença, a melhor era aquela extinta sob uma camada de uma espécie de areia chamada pozolana. Tal ingrediente, em sua opinião, oferecia grande vantagem se usado em substituição à areia. Foram indicadas no seu texto várias jazidas, além daquela situada nas imediações do Vesúvio29.

Manuel Losada considerou a pozolana como uma areia de cor de porcelana, pois disse o seguinte:

A areia de cor de porcelana, a qual nas obras e construções que se fazem nas águas, faz grandíssimo efeito, pois com rapidez faz excelente pega e os edifícios ficam fortíssimos ${ }^{30}$.

O material apontado por este autor devia, realmente, ser uma pozolana natural, pois apesar de ter sido chamado de areia, foi recomendado para uso em obras aquáticas, e também não foi mencionada a mistura com cal.

Philibert de l'Orme, ao citar Plínio - que havia falado na diversidade de terras e da "areia de Putzo/ $/ 31$ ", e em outros tipos de terras que endureciam como se fossem pedras -, também utilizou o termo pourcelane, informando que era uma "areia" negra ${ }^{32}$. Não restam dúvidas que o material ao qual se atribuía esta denominação era a pozolana vitruviana.

Por outro lado, há discrepância nas informações a respeito das colorações existentes. A este respeito destacam-se ainda, a título de ilustração, as definições dadas por Belidor e por J. F. Blondel, que são muito similares:

Pozolana. Terra avermelhada que substitui a areia na Itália e que, misturada com cal, propicia uma excelente argamassa que endurece em presença de água ${ }^{33}$. (grifo do autor)

Este pó é avermelhado, e não é outra coisa que a terra bruta, misturada com o tufo pelos fogos subterrâneos que saem das montanhas em torno das quais são tiradas ${ }^{34}$.

No texto Principii di architettura civile ${ }^{35}$, e em outros, como nos de Félibien e de Rieger ${ }^{36}$, que o antecederam, a pozolana foi considerada como areia. Félibien a indicou como ótimo material por propiciar uma boa ligação, podendo até ser usado em abóbadas. Só que, estranhamente, não mencionou seu uso em obras hidráulicas, a utilidade maior deste materia| ${ }^{37}$.

Destaca-se que, no catálogo da exposição internacional havida em Londres, em 1862, ao fazer-se referência às pozolanas de Santarém (Ilha 
de São Miguel) e da llha Terceira, ambas em Portugal, elas foram chamadas de massapez ${ }^{38}$.

No Brasil, a denominação massapê significa um solo constituído basicamente por argila montmorilonita, bastante freqüente, dentre outros locais, no Recôncavo Baiano ${ }^{39}$. Frisa-se este ponto apenas para que se fique atento para as eventuais confusões decorrentes de termos similares usados para produtos completamente diferentes, o que fatalmente leva a erros de interpretação, principalmente quando se trata do estudo de materiais antigos ${ }^{40}$. Já se teve a oportunidade de abordar o problema ao tecerem-se considerações acerca do saibro, no capítulo sobre areia, por exemplo.

Segundo Manuel Hijosa, o tradutor para o idioma espanhol do texto de Giovanni Branca, na versão italiana ter-se-ia falado de pozolana, produto usado na Itália em substituição à areia, mas como esse material não tinha uso na Espanha, não foi traduzido o trecho correspondente ${ }^{41}$. Porém Hijosa, como alguns dos autores consultados, não considerou a pozolana como areia, mas, sim, como um eventual substituto para aquele material. Isto é mais condizente com a realidade, do ponto de vista atual, tendo-se em mente a definição de areia.

Negreiros, por sua vez, classificou a pozolana como areia. Este era, de acordo com o seu texto, o único material de construção que não havia em Portugal na época, pois os demais eram disponíveis, e de ótima qualidade. Ainda na opinião do mesmo autor, a areia disponível em Portugal só apresentava o inconveniente de uma secagem mais lenta do que a pozolana, porém propiciava o mesmo resultado, após seca ${ }^{42}$.

Uma argamassa feita simplesmente com cal aérea e areia não apresenta hidraulicidade. Logo, não poderia ter o mesmo comportamento de uma argamassa feita com pozolana. O que se pode inferir é que, ou Negreiros fez a comparação baseado no uso de uma mistura à base de cal hidráulica, ou analisou obras executadas em locais secos. Neste último caso, a pozolana funcionaria possivelmente como um inerte.

Negreiros, em outra passagem do seu texto, disse que a pozolana, apesar de apresentar secagem mais rápida do que uma argamassa tradicional de areia, adquiria tanta solidez que propiciava aos construtores a redução da espessura das paredes, o que estava sendo colocado em prática na Itália, na época ${ }^{43}$. 
Da análise desta informação, conclui-se, mais uma vez, que o desempenho final de uma argamassa de cal e areia não podia ser realmente igual àquele de uma argamassa de cal e pozolana, como este mesmo autor havia afirmado anteriormente.

Para Belidor, autor anterior a Negreiros, a argamassa que continha pozolana era a melhor do mundo, tanto para lugares secos quanto úmidos $^{44}$. Em um texto do século XIX, da autoria de Berthault-Ducreux, entretanto, já se destacava que o comportamento do material a seco era diferente daquele obtido em ambiente úmido, o que se pode perceber através da transcrição feita:

Não apenas o bom pó de tijolo, mas também a melhor pozolana, se comporta com a cal, mais ou menos como um pó inerte, se a argamassa da qual ela faz parte não for imersa ou ao menos mantida sob umidade ${ }^{45}$.

A areia funciona como carga, na argamassa. Logo, qualquer outro material pulverulento, que não reagisse com a cal, funcionaria de modo semelhante. Isto aconteceria quando as argamassas com pozolana ou pó cerâmico não estivessem imersas, ou não fossem mantidas úmidas.

Como Negreiros e Belidor diziam que o material se comportava a contento a seco, supõe-se que as propriedades hidráulicas do material não estavam sendo consideradas, no momento. De fato, as argamassas de cal e areia teriam comportamento completamente diferente se usadas em ambientes secos ou úmidos.

Sobre argamassas com pozolana, Alessandro Vittorio d'Antoni Papacino deu uma informação diversa dos demais autores investigados:

Deverá haver toda attenção precisa na construcção destes edificios, para que pela continuação do tempo se não introduza a humidade que resulta das chuvas, e neve nos armazens, que devem ser bem secos. Para isto he necessario, que não só no tempo da construcção, mas ainda depois, estes edificios estejão cubertos naquelles paizes que por serem sugeitos a geadas, fica inutil o uso da possolana ${ }^{46}$.

Este foi o único autor encontrado que mencionou que a argamassa com pozolana não serviria em locais sujeitos a geadas. Talvez porque a água usada na mistura de endurecimento da argamassa, congelandose, não permitisse que a reação cal-pozolana ocorresse, de modo que a argamassa não adquiriria propriedades pozolânicas. 
O português António Coutinho (séc. XX) informou que era possível a classificação do magma a partir do qual uma determinada rocha teria sido formada, através da análise química, em óxidos elementares, da dita rocha $^{47}$. No entanto, este mesmo autor julgou que era difícil concluir a que tipo de magma pertencia uma determinada pozolana, visto que seria necessário um alto grau de alteração da rocha para que se tivesse um material com altas propriedades pozolânicas. Mas complementou:

[...] o conhecimento destas rochas permite não só uma arrumação lógica dos diferentes tipos de pozolana, mas também prever mesmo o comportamento pozolânico de certas rochas lávicas ${ }^{48}$.

A pozolana é um tipo de solo especial, de origem vulcânica, que contém uma componente altamente vítrea e vários minerais associados. Atualmente, já é possível, através de ensaios de laboratório, identificar-se, em uma argamassa antiga, de qual vulcão provém a pozolana eventualmente nela presente. Isto é conseguido pela análise dos minerais associados, com o auxílio da difração de raios-X. Por exemplo, os italianos Franco Massazza e Mario Pezzuoli (séc. XX), ao mencionarem os resultados dos ensaios realizados em amostras do concreto romano utilizado nas fundações do Coliseu, informaram terem detectado, por meio de difração de raios- $X$, leucita, diopsita, melilita e quartzo (provenientes dos finos e da pozolana, materiais não retidos na peneira de malha 40mm), e hidróxido de gehlenita e calcita (resultantes da reação pozolânica e da carbonatação da cal) $)^{49}$.

De maneira similar, através de análises laboratoriais, foi identificada a pozolana usada por Michelangelo Buonarotti (1475-1564) na Capela Sixtina como sendo do Lazio, da região ao Norte de Roma, e não da região da Campania, como se pensava. Isto porque os minerais associados à pozolana, na argamassa analisada, eram típicos de um vulcão existente no Norte de Roma, e não estavam presentes nos outros vulcões das imediações daquela cidade ${ }^{50}$.

Sabe-se que o arquiteto José Trindade Chagas detectou pozolana em algumas das amostras da taipa do castelo de Alcácer do Sal, em Portugal. No entanto, de acordo com a bibliografia, as jazidas portuguesas desse material eram desconhecidas na época em que a obra foi erguida. Valeria a pena confrontar as características das amostras encontradas 
na taipa do supracitado castelo com as das pozolanas provenientes de jazidas conhecidas no país. Desta maneira, verificar-se-ia se o material utilizado foi local ou veio de alhures, trazidos por antigos navegantes. Trabalho similar foi feito pelo italiano Giacomo Chiari (séc. XX) e por outros investigadores para o mausoléu de Sant'Elena ${ }^{51}$.

A título de ilustração, indicam-se elementos que podem estar presentes nas pozolanas: óxidos de cromo, alumínio, ferro, magnésio, manganês, cobalto e níquel ${ }^{52}$; feldspatos sódicos, potássicos, calco-sódicos (plagioclásios), cálcicos; feldspatóides (leucitas, nefelinas, sodalitas, noseanas ou noselitas, hauynas, melilitas); além desses, podem ainda ser encontrados piroxenas, olivinas, biotitas, apatitas, zircônios, magnetitas, ilmenitas e hornblendas ${ }^{53}$.

Atualmente, na realização de ensaios padronizados pelo grupo Normal ${ }^{54}$, usa-se a pozolana superventilada de Salone (Toscânia). Procedese desta maneira de modo a evitar divergências de comportamento entre os vários tipos de pozolanas existentes na natureza, em decorrência de diferentes constituições de materiais, quer entre os tipos dos minerais associados presentes, quer no que diz respeito aos seus percentuais.

É inviável a identificação da presença de pozolana em uma argamassa antiga, unicamente através da análise da sua composição química. Por este meio, pode-se apenas constatar que o material apresenta características hidráulicas (pozolânicas), mas não é possível afirmar se a responsabilidade por tais características foi decorrente da inclusão de pozolana à mistura. O comportamento pozolânico de determinada argamassa pode ser atribuído, pois, a diversas composições.

Leduc, ao mencionar os materiais usados pelos holandeses, informou que, na falta de pozolana, usavam trass ${ }^{55}$ de Andernach, um tufo vulcânico das margens do Reno (trecho do vale de Brohebach) ${ }^{56}$.

A análise química não serve para identificar as pozolanas, mas a microscopia permite uma clara caracterização do material: além da diferença, facilmente visível, entre os diversos minerais associados, a pozolana aparece sob uma forma característica ${ }^{57}$ (il. 13). Esta é mais uma prova da importância da interdisciplinaridade para a conservação e a restauração: se o profissional se valer apenas da colaboração de um químico na identificação deste componente das argamassas, a resposta 
obtida pode não ser conclusiva, mas com a contribuição de um geólogo, não restam dúvidas se o material é ou não uma pozolana.

O italiano Girolamo Masi, autor que considerou a pozolana como uma espécie de terra e defendeu o princípio que, se misturada com a cal, a argamassa resultante seria a melhor possível| ${ }^{58}$, indicou como sendo de ótima qualidade para a construção o tipo existente nos arredores de Roma e de Pozzuoli, também avermelhado, porém tendente ao preto. Em sua opinião, no entanto, a pozolana branca, também disponível naqueles locais, era inadequada para os mesmos fins ${ }^{59}$.

Jean-Baptiste de Romé de I'Isle ainda citou, além das pozolanas pretas, vermelhas e brancas, outros tipos existentes:

As pozolanas cinzas, marrons, pretas, amareladas, avermelhadas etc., que não são mais que detritos das mesmas lavas porosas e celulares, passando com o tempo ao estado de cor ocre ou argiloso, e com a qual fazemos este ligante tão vantajoso para as construções sob a água ${ }^{60}$ (grifo do autor)

Sabe-se que há pozolanas de várias cores. A simplificação da indicação, por parte de alguns dos autores consultados, deve ter sido ocasionada pelo seu desconhecimento de muitas das variedades existentes. A cor, entretanto, não é responsável por diferenças no seu comportamento, porém dá indícios de proveniências diversas e outras diferenças, principalmente no que diz respeito à sua fase vítrea ${ }^{61}$.

No supracitado texto de De Romé de l'Isle, foi dito que as pozolanas terminavam por se converter em um pó argiloso vermelho ou amarelado, macio e untuoso ao tato ${ }^{62}$. Não ficou claro se o autor julgava que as pozolanas se transformavam ainda em seu estado natural ou após utilizadas na argamassa, nem a qual tipo específico se referiu. Pelos comentários feitos, a impressão que se teve foi que o material ao qual De Romé de l'Isle fez menção foi realmente uma argila.

\section{Pó cerâmico}

O pó cerâmico teve ampla utilização em argamassas, no decorrer dos séculos. Referências a este ingrediente são encontradas na bibliografia, ao menos desde a época vitruviana, tendo sido freqüentemente citado com a denominação de ciment ou cyment. O que variou, ao longo 
de todo este período, foi o tipo de cerâmica utilizada na pulverização (tijolos ou telhas, novos ou velhos), sua proporção, a inclusão, ou não, de outros componentes na mistura e o tipo de aglomerante usado.

Vitrúvio ${ }^{63}$, Faventino e Paládio Rutílio ${ }^{64}$ aconselharam a adição do pó cerâmico para melhorar a qualidade da argamassa, se feita com areia de rio. Martini, no entanto, sugeriu uma mistura mais complexa envolvendo este componente, de modo a conferir certa impermeablidade ao produto final, como pode ser constatado através da citação a seguir:

Se desejarmos fazer algum esmalte, estuque, concreto ou uma verdadeira calçada,devemos pegar dois alqueires de pó de telha, dois alqueires de cal, meio alqueire de limalhas de ferro. E estes juntos e misturados com decocção de casca de olmo. E assim, por 15 dias mexendo e embebendo, depois esmaltando aquilo que quer, passando todo dia borra de azeite ou gordura com a colher de pedreiro, ao fim verás que libera água ${ }^{65}$. (esta citação é similar à de Cataneo)

Neste caso, entretanto, foi acrescentada, aparentemente com a intenção de melhorar o desempenho da mistura, a borra do azeite ou a gordura.

D'Aviler recomendou o uso de material cerâmico pulverizado (preferencialmente o uso de pó de telha), além da cal e da areia, na proporção 1:1,5 (cal, ciment) quando a intenção fosse conferir hidraulicidade à argamassa ${ }^{66}$. Ressalta-se que este foi o primeiro autor estudado que fez referência explícita à mistura de pó de material cerâmico com a cal viva $^{67}$.

Sendo o pó um inerte, não deveria reagir, ao ser misturado com o óxido de cálcio, ao longo do processo de extinção deste. Logo, possivelmente não deveria haver diferença em misturar o pó com a cal viva, ou com a cal extinta.

Em vários textos antigos, principalmente dicionários especializados, como, por exemplo, naquele da autoria de Félibien, encontrou-se, acerca do uso do ciment, a seguinte informação:

$[\ldots]$ nosso ciment para fazer a argamassa, que é a telha moída $[\ldots]^{68}$.

Já no dicionário de Belidor, a definição dada foi semelhante, mas no mesmo verbete, foi indicado que este material poderia ser empregado em argamassas em contato com a água: 
Ciment. É a telha moída, que misturada com a cal, faz a melhor argamassa, e que é de bom uso para as obras feitas na água ${ }^{69}$.

$\mathrm{Na}$ bibliografia pesquisada, foram ainda encontradas outras referências ao uso de material cerâmico moído nas argamassas, com a indicação que deveria ser oriundo de telhas, como no exemplo acima. Já em outros textos, como em La science des ingenieurs, do próprio Belidor, foi especificado que o material deveria provir de telhas velhas, bem cozidas, pulverizadas, sendo o pó passado por peneira de padeiro:

Aquela que será empregada nos rebocos e cisternas, tanto por cima quanto por baixo, será feita de cascos de telhas velhas bem cozidas, sem que nela sejam usados tijolos; ela será bem batida, pulverizada e passada na peneira de padeiro, e a argamassa feita com dois quintos de cal viva de Boulogne e três quintos do dito ciment, tudo bem batido e resolvido todos os dias consecutivos até aquele em que será usada ${ }^{70}$. (esta informação consta das especificações para a cisterna de Calais)

Notou-se a indicação do uso de cal viva no caso desta argamassa, feita com o traço 1:1,5 (cal, pó de telha $)^{71}$. O mesmo tipo de argamassa foi também recomendado em outros trechos de tal livro, com igual finalidade $^{72}$. Belidor indicou ainda o traço 1:1 (cal, pó de telha) para obras

[...] que não são de responsabilidade, mas que merecem alguma atenção ${ }^{73}$.

Em Architecture hydraulique, Belidor descreveu um engenho para o preparo do ciment $^{74}$, apresentando inclusive uma gravura elucidativa do mesmo ${ }^{75}$ (il. 14).

No preparo do ciment, certos autores recomendaram que fosse usado pó de tijolo, ao invés de pó de telha, como a maioria indicava. Foram levantadas algumas hipóteses para justificar a sugestão para o pó cerâmico ser obtido unicamente a partir da pulverização de telhas, de preferência, velhas:

- Por ser um material que deveria sempre ter um melhor cuidado no preparo, no que diz respeito à moldagem e ao cozimento, já que teria que ser utilizado como agente de proteção contra a penetração da água nas construções, ou seja, em coberturas ou no revestimento de paredes sujeitas a constantes chuvas; 
- Pela maior oferta do material;

- Porque talvez o material velho, intemperizado, conferisse melhores propriedades à argamassa ${ }^{76}$;

- Se fossem usadas telhas novas, aparentemente se estaria desperdiçando mão-de-obra. Assim sendo, a telha só deveria ser usada após haver cumprido a sua função básica: cobrir os imóveis, impedindo o ingresso da água de chuva. O problema que podia ocorrer, neste caso, seria a introdução de sais solúveis na argamassa, caso as telhas fossem provenientes de coberturas nas proximidades do mar, zona rica em aerossol salino ${ }^{77}$;

- Por ser um material de pouca espessura, haveria possibilidade de ser mais bem queimado que o tijolo.

J. F. Blondel explicou que o ciment deveria ser de pó de telha, porque o tijolo era mais terroso que a telha (deste modo, o seu pó não teria tanta capacidade de resistir a cargas). Logo, só deveria ser utilizado quando não houvesse telha disponível ${ }^{78}$.

Quanto à recomendação dada por certos autores para o pó ser peneirado, era plenamente justificável: propiciaria uma maior homogeneização do produto final e, conseqüentemente, a argamassa apresentaria propriedades similares em sua totalidade.

$\mathrm{Na}$ opinião do autor do texto Memoires critiques d'architecture, já que a cal, sozinha, não servia para unir as pedras, podia ser misturada com o material cerâmico pulverizado, de modo a ter o seu uso viabilizado ${ }^{79}$. O ciment, em sendo constituído por pó cerâmico ${ }^{80}$, seria feito de terra alterada pelas chuvas, que lhe acrescentaria sais de cobre e de enxofre ${ }^{81}$, daí o produto reter a causticidade dos seus sais:

A pulverização ou o amassamento do ciment lhe dá diferente configuração; ele fica cheio de pontas, sua substância é estável; é porque ele não esmaga as pontas sob nenhum outro mineral, e sustenta todo o peso; a abundância de seus sais e a multiplicidade de seus ângulos, Ihes conferem sua tenacidade, e thes fornecem meios mais imediatos e mais vivos de melhor aderência. É dessa boa adesão que vem o provérbio "ele construiu de cal e ciment, pois uma obra deste tipo é eterna ${ }^{82}$. (grifo não existente no original)

O autor concluiu, pois, que o pó de telha, ao ser misturado com a cal, emprestar-Ihe-ia a abundância de sais e sua dureza e, pelo fato de 
ser multifacetado, melhoria as características do material. Deste modo, se poderia obter uma obra de grande durabilidade.

Pensar que o ciment era composto por vários tipos de sais é apenas mais uma prova do desconhecimento da constituição dos diversos materiais usados na construção. Quanto à melhoria da qualidade da mistura devido à angulosidade apresentada pelas partículas de materiais cerâmicos, a observação faz sentido, pois propicia, de fato, uma maior aderência entre os componentes da argamassa.

Uma obra feita com bons materiais, realmente, possui grande durabilidade, daí o autor do texto acima transcrito ter feito alusão ao conhecido provérbio. Porém considerar a obra como eterna era um exagero que se admite somente como metáfora. No entanto, esta não foi a única referência encontrada dizendo que um determinado material poderia propiciar durabilidade infinita a uma edificação.

O ciment foi material de ampla difusão até o século XVIII, sempre que se desejava conferir certa hidraulicidade a uma argamassa. Foi considerado por alguns autores contemporâneos, precisamente por esta sua propriedade, como um aditivo pozolânico. John Ashurst, por exemplo, afirmou o seguinte:

Pozolana tornou-se um nome genérico para todo aditivo que irá reagir
com cal para produzir uma pega hidráulica [...]. Construtores romanos
também usaram tijolos, telhas e vasos cerâmicos pulverizados e
escória de ferro como aditivos pozolânicos ${ }^{83}$.

Através dos ensaios de capilaridade ascendente realizados no NTPR, concluiu-se que a função do pó cerâmico em uma argamassa, no sentido de evitar a penetração da umidade, não estava correlacionada à inibição da capilaridade ${ }^{84}$, mas, sim, à distribuição da porosidade ${ }^{85}$. Sabe-se que o tamanho problemático dos poros está compreendido entre 0,1 e 1m. A inclusão de pó cerâmico na mistura aparentemente é responsável pela redução da quantidade de poros com esta dimensão. Logo, a argamassa realmente resiste mais à ação da água, tornando-se menos susceptível à degradação dos sais, por cristalização.

Em Salvador, foram encontrados maciços de argamassas compostos por cal, areia e material cerâmico pulverizado nas escavações arqueológicas efetuadas no Forte de Santo Alberto, construção do período colonial. Estes maciços, que até hoje se apresentam bastante íntegros, foram executados nas plataformas das canhoneiras, de modo a absorverem o impacto 
transmitido às carretas pelos disparos dos canhões. Esta é uma prova concreta da utilização da argamassa com pó cerâmico.

\section{Terraços fluviais do Baixo Reno}

Este ingrediente, mencionado por vários autores franceses e italianos do século XVIII, aparentemente ainda não foi estudado pelos investigadores contemporâneos que estão envolvidos com a constituição das argamassas antigas. Ao menos não foram encontrados em livros, revistas especializadas, nem nos anais de congressos recentes sobre o assunto, informações a este respeito. Tampouco se conseguiu descobrir investigações em andamento no Centro Gino Bozza (CNR-Milão), no laboratório da Superintendência dos Bens Históricos e Artísticos (Veneza) e no LNEC (Portugal). No entanto, em um texto de finais do século XIX, da autoria de Castanheira das Neves, foi citado um material que teria propriedades similares às das pozolanas, e que deveria ser este ao qual se faz referência:

[...] 'trass' de Holanda (rocha feldspathica muito abundante nas margens do Rheno $[\ldots]^{86}$.

A definição dada por Belidor, em La science des ingenieurs, para este material, foi a seguinte:

Terraços fluviais do Baixo Reno. É uma espécie de pó feito de uma terra que se acha bem perto do Baixo Reno, na Alemanha, e nas imediações de Colônia; nós a cozemos como o gesso; e a reduzimos em seguida a pó. Este pó é excelente para a composição da argamassa quando queremos construir na água ${ }^{87}$.

No mesmo texto foi informado que os terraços fluviais do Baixo Reno apresentavam tonalidade cinza e, se puro - o que era raro, no entender de Belidor - era ótimo para obras aquáticas e para resistir às intempéries.

No Dictionnaire portatif de l'ingénier, do próprio Belidor, texto publicado vinte e seis anos depois de La science des ingenieurs, também se encontrou exatamente a mesma definição ${ }^{88}$, o que prova que este material, com propriedades hidráulicas, ainda era empregue, ao menos na França, naquele período.

Para fazer uma argamassa com tal produto colocava-se uma camada do mesmo sobre uma camada de cal viva, previamente molhada. Após um repouso de dois a três dias, misturava-se tudo ${ }^{89}$. 
Os terraços fluviais do Baixo Reno entravam na argamassa em substituição da areia, apesar de se ter, pela simples leitura da definição dada por Belidor, a impressão de que o material seria um aglomerante hidráulico, e não um agregado, já que foi informado que o material era submetido à queima e reduzido a pó.

J. F. Blondel, por sua vez, descreveu o terrasse como sendo:

[...] uma pedra de cor acinzentada, que encontramos perto do Baixo Reno, na Alemanha, e nos Países-Baixos. Ela se prepara como o gesso, e nós a esmagamos em seguida para a destemperar com a cal ${ }^{90}$.

No texto atribuível a Milizia, publicado em 1785, também foram encontradas informações a respeito do uso deste material:

No entorno de Colônia e do Baixo Reno se usa uma espécie de pó cinza chamado Terraços fluviais do Baixo Reno, e se faz de uma terra que se coze e se macera como o gesso [...]. Até os calhaus de qualquer lugar espedaçados, e reduzidos a pó, dão uma espécie de Terraços fluviais do Baixo Reno, que unido com a cal faz um ótimo ligante ${ }^{91}$.

Por mais de meio século, pelo menos, este material foi utilizado na confecção de argamassas. Supõe-se que os chamados terraços fluviais do Baixo Reno deveriam consistir em tufo ou lava vulcânica, já que a bacia do Reno é rica nesse tipo de rocha, ou então eram materiais similares ao trass. Castanheira das Neves, por exemplo, citou o trass de Holanda, como visto anteriormente. Sendo assim, poderia ser incluído no rol das pozolanas naturais. Levanta-se a hipótese que o trass de Andernach, mencionado por Leduc ${ }^{92}$, fosse o mesmo produto.

\section{Cinzas de Tournai}

De acordo com os ensinamentos de Belidor, o material conhecido como cinzas de Tournai era muito utilizado em argamassas, na sua época, mas ninguém havia explicado bem suas propriedades até então. Por esta razão, tal engenheiro militar se propôs a dar algumas informações a respeito do assunto. Estas informações constam tanto do livro La science des ingenieurs, quanto do Dictionnaire portatif. A definição apresentada por Belidor foi a seguinte:

Cinzas de Tournai. O entorno de Tournai fornece uma pedra muito dura, da qual fazemos uma cal excelente. Quando esta pedra está no 
forno, destaca-se em pequenas parcelas que caem na grelha, onde elas se misturam com a cinza do carvão mineral; e como esta cinza não é outra coisa que pequenas parcelas de hulha calcinada, é a mistura que com elas se faz que compõe o que chamamos Cinzas de Tournai, que são usadas tal como as tiramos do forno ${ }^{93}$.

Belidor ensinou, ainda, que as cinzas de Tournai eram ótimas para obras aquáticas, pelo fato do material apresentar similaridades à mistura de cal com carvão ou mache-fer pulverizados. Ambas as argamassas compostas com estes ingredientes teriam, pois, boa hidraulicidade.

O material foi definido de maneira similar no texto setecentista atribuível a Milizia ${ }^{94}$ e, também, no dicionário de Bouillet, do século XIX, como pode ser verificado a seguir:

[...] mistura de pedra de cal calcinada e de cinzas de carvão mineral, que serve de ligante para os cadinhos e que empregamos também às vezes como ligante hidráulico ${ }^{95}$.

As cinzas de Tournai consistiam, provavelmente, em uma mistura de pierre bleu de Tournai com hulha, calcinadas em conjunto. Sendo a pierre bleu de Tournai um calcário sem peculiaridade alguma, ou seja, que não apresenta constituintes que o diferenciam de outro qualquer, esta mistura provavelmente deve ter existido em outros locais, em decorrência da calcinação de outros tipos de calcários usando-se a hulha como combustível.

Seria possível, através de alguma análise química ou microscópica, identificar as cinzas de Tournai dentro de uma argamassa, ou simplesmente se constataria ser uma argamassa com certa hidraulicidade? Talvez só se pudesse verificar a hidraulicidade da mistura. Não se pode afirmar isto, ao certo, sem o auxílio de ensaios laboratoriais. Existe a possibilidade de, por meio da combinação de análises diversas ${ }^{96}$, concluir-se exatamente que este material estava presente em alguma amostra de argamassa antiga.

\section{Notas}

1 SANTIAGO, Cybèle Celestino. Aditivos orgânicos em argamassas antigas. Salvador, UFBA, 1992. Dissertação de mestrado. Cap. III, p. 16.

${ }^{2}$ BOUILLET, M. N.. Dictionnaire universel des sciences, des lettres et des arts. $12^{\mathrm{a}}$ ed. Paris, Hachette et $C^{\text {ie }}$, 1877. p. 1002 - "Machefer - [...] scories à demi vitreuses, qui s'agglomèrent dans les foyers des forges où l'on travaille le fer et forment le résidu de diverses houilles qu'on brûle. Elles sont composées d'oxydes terreux, de schistes et d'un peu d'oxyde de fer // [...] escórias semi-vitrosas, que se aglomeram nas fornalhas das 
forjas onde trabalhamos o ferro e formam o resíduo de diversas hulhas que queimamos. Elas são compostas de óxidos terrosos, de xistos e de um pouco de óxido de ferro.

${ }^{3}$ BELIDOR, Bernard Forest de. La science des ingenieurs. Paris, Claude Jombert, 1729. L. III, Cap. IV, p. 12.

${ }^{4}$ COUTINHO, António de Sousa. Pozolanas, betões com pozolanas e cimentos pozolânicos..., Apêndice IV, p. 151.

${ }^{5}$ DAVEY, Norman. A history of building materials, London, Phoenix House, 1961. Cap. XII, p. 102.

${ }^{6}$ CASTRO, Alberto Gomes de. LIMA, António Vasconcelos. Ciência e tecnologia dos materiais. Gondomar, Universidade de Trás-os-Montes e Alto Douro, 1988. Cap. VI, p. 497.

7 VITRUVIO, Marco Lucio. Los diez libros de arquitectura, tradução, prólogo e notas de Agustín Blánquez. Barcelona, Iberia, 1955. L. II, Cap. VI, p. 45.

${ }^{8}$ MASSAZZA, Franco; PEZZUOLI, Mario. «Some teachings of a roman concrete», Mortars, cements and grouts used in the conservation of historic buildings (anais do simpósio de Roma, 3-6.11.1981). Roma, ICCROM, 1982, p. 220-245. p. 220.

${ }_{9}^{9}$ [MILIZIA, Francesco]. Principii di architettura civile... t. III, L. I, Cap. IV, p. 39.

${ }^{10}$ Guillaume Philander, um dos famosos comentaristas do tratado vitruviano (séc. XVI).

${ }^{11}$ [MILIZIA, Francesco]. Principii di architettura civile..., t. III, L. I, Cap. IV, p. 37. - la pozzolana altro non sia che un miscuglio di terra con tufo, con bitume, e con qualche altra parte sulfurea, miscuglio preparato da fuochi sotterranei.

${ }_{12}$ VITRUVIO, Marco Lucio. Los diez libros de arquitectura, tradução de Agustín Blánquez..., L.II, Cap. VI, p. 45. - [...] en las entrañas de aquellos montes hay tierra y numerosas fuentes de agua caliente, que no existirían si no estuviesen debajo fortísimos fuegos, alimentados o por azufre o por alumbre o por betún. Este fuego y estas llamas, al penetrar y actuar a través de los meandros y venas de la tierra, la hacen ligera, y el tufo (o la toba) que allí existe es lúmido y enjuto.

${ }^{13}$ ZANINI, Gioseffe Viola. Della architettura. $2^{2}$ impr.. Pádua, Giacomo Cadorino, 1677. L. I, Cap. XV, p. 66.

${ }^{14}$ BELIDOR, Bernard Forest de. La science des ingenieurs..., L. III, Cap. IV, p. 11.

${ }^{15}$ NEGREIROS, Jozé Manuel de Carvalho. Jornada pelo Tejo, [Lisboa], Cód. 80 (AHM), 1792. fls. $54 \mathrm{~V}$.

${ }^{16}$ PLINIO (o Antigo). Historia naturale. Trad. de Ludovico Domenichi. Veneza, G. Ferrari, 1561/1568. L. XXXV, Cap. XII, p. 1113. - Sonci anchora oltra queste altre specie di terra: \& chi non si maraviglierebbe, che la peggior parte d'essa, \& perciò chiamata polvere, ne' colli di Pozzuolo, si mettesse per riparo con l'onde del mare? Laqual polvere subito ch'è tuffata diventa pietra d'un pezzo, ch'ogni di si fa piu inespugnabile \& piu forte, massimamente mescolandosi con calcina di Cuma.

${ }^{17}$ ALBERTI, Leon Battista. De re ædificatoria (Florença, 1495). Trad. de Giovanni Orlandi, introd. e notas de P. Portoghesi, ed. bilingüe latim/italiano, L'archittetura, Milão, II Polifilo, 1966. t. I, L. II, Cap. IX, p.142. - Nella zona di Pozzuoli vi è in abbondanza un tipo di polvere che mischiata all'acqua di mare si indurisce in pietra. 
${ }^{18}$ CATANEO Pietro. I quattro primi libri di architettura (Veneza, Figliuoli di Aldo, 1554), facsímile, Ridgewood, The Gregg Press Incorporated, 1964. Cap. III, fls. 29 - Destaca-se que esta informação foi dada por Cataneo no capítulo sobre areia do seu tratado. - La po/vere pozzolana di campagna intorno al monte Vessuvio [sic], porta il vanto di tutte le rene: peroche, essendo di tufo secco arsicciato, essendone uscito il liquore, ne diviene piu leggiera, \& migliore: \& nel mescolarla dipoi con la calcina, \& con l'acqua, ricevendo subito il liquore, fanno insieme corpo; \& con prestezza ricevendo l'humore, fanno le fabriche durissima presa, alle quali non solo la fortuna del mare, \& la possanza dell'acqua non può nuocere, ma si indurisce di maniera la fabrica, massime la parte sotto l'acqua, che di una solo pietra tutto il muro si dimostra, \& ciò non è meraviglia: quando vogliono, che, ponendo in mare la detta polvere pozzolana, da per se sola diventa pietra.

${ }^{19}$ BLONDEL, Jacques-François. Cours d'architecture. Paris, Desaint, 1777. v. VII, t. VI, Cap. III, p.127. - [...] matière bitumineuse, qui se trouve dans les environs du Vesuve, laquelle est composée de parties métalliques \& de petits cristaux très âpres au toucher: En mêlant cette pozzolane avec de la chaux de marbre ou de coquillage, il en résulte un mortier que l'eau affermit au lieu de le détruire.

${ }^{20}$ [MILIZIA, Francesco]. Principii di architettura civile ..., t. III, L. I, Cap. IV, p. 38. - Vitruvio, dal non vedere cave di pozzolana che ne' contorni di Napoli, si lambiccò il cervello a spiegare, perchè altrove non ve ne fossero: ma altrove ve n'erano; e Roma, dove viveva Vitruvio, ne abbondava più di qualunque altro luogo. Possibile ch'ei non le vedesse! Forse non si erano ancora scoperte.

${ }^{21}$ BELIDOR, Bernard Forest de. La science des ingenieurs..., L. III, Cap. IV, p. 11 - Este autor indicou pozolanas na Itália e nos Países Baixos.

${ }^{22}$ NEGREIROS, Jozé Manuel de Carvalho. Jornada pelo Tejo..., fls. 54v - Foram mencionadas, nesse texto, pozolanas vermelhas e pretas em Portugal.

${ }^{23}$ BRANCA, Giovanni. Manuale d'architettura. Comentários e acréscimos de Giovanni Soli. $5^{a}$ ed., Modena, Soc. Tipografica, 1789. L. I, Cap. IV, p. 9.

${ }^{24}$ Id., loc. cit. - [...] minuzzoli di peperino di S. Fiorge con certa terra di color bigio nericcio, che cavata a Monte Rotondo in luogo detto Rene, materia ambedue vetrine, e perciò resistente all'umidità come la pozzolana di Roma materia vetrina anch'essa, e che a giudizio d'alcuni ha sofferto l'azione di antichi vulcani.

25 Tufo dos montes Albanos, na província de Roma.

${ }^{26}$ [MILIZIA, Francesco]. Principii di architettura civile..., t. III, L. I, Cap. IV, p. 38. - In Napoli e ne' suoi contorni trovansi soterra strati copiosi d'una certa specie di pietruzze simili a picciole pomici, e alquanto giallette come pezzi di tegola o di coppi pesti, dette colà rapilli, cioè lapilli. Anche questa materia è produzione di vulcani, e fa ottima lega colla calce.

${ }^{27}$ RODOLICO, Francesco. Le pietre della città d'Italia. $2^{\mathrm{a}}$ ed., Florença, Felice le Monnier, 1953. p. 392 - [...] sotto a' tuffi cavano la pozzolana di color bianco alquanto rimesso, et ottima nelle malte, e sotto alla pozzolana ritrovano il grapello ovvero serepillo (come essi dicono), il quale è una materia alquanto gialletta, e come pezzetti di tegoli o embrici pesti: il quale serve a far i terrazzi, e del più minuto l'adoprano per granzolo nell'intonacar le mura.

${ }^{28}$ SCAMOZZI, Vincenzo. L'idea della architettura universale (Veneza, V. Scamozzi, 1615). facsímile, n. 9 9, Sala Bolognese, Arnaldo Forni, 1982. Parte II, L. VII, Cap. XXI, p. 236 - In Napoli oltre à molti altri luoghi del regno cavano una certa materia, laquale chiamano grapillo, che à parer nostro è una specie di tufo duro, \& in ciottolini como avelllanne [sic], e nocciuoli, e de'più minuti, di color tendente al giallo: laonde del più grosso, e del mezano si servono per 
far terrazzi, e del più minuto lo serbano per meschiar nelle malte, per intonacar le mura; essendo che cosi in quelli come in questi fa una presa grandissima.

${ }^{29}$ FILARETE (Antonio Averlino). Trattato di architettura, Milão, II Polifilo, 1972. v. I, L. III, p. 66 - [...] e questa la cavano delli campi e strade como si fa ancora qui a Milano // ...e esta a cavam nos campos e estradas como se faz ainda aqui em Milão.

${ }^{30}$ LOSADA, Manuel. Critica y compendio especulativo-practico de la arquitectura civil, Madrid. Antonio Marin, 1740. t. I, tratado I. Proemiales. Proposição V, p. 11/12. - La arena de color de porcelana, la qual en las obras, y fabricas que se hacen en las aguas, hace grandissimo efecto, porque con presteza hace grandissima presa, y los edificios salen fuertissimos.

${ }^{31}$ Pozzuoli.

${ }^{32}$ DE L'ORME, Philibert. Le premier tome de l'architecture (Paris, Frederic Morel, 1567), fac-símile, Traités d'architecture. Paris, Léonce Laget, 1988. L. I, Cap. XVII, fls. 28.

${ }^{33}$ BELIDOR, Bernard Forest de. Dictionnaire portatif. Paris, Charles-Antoine Jombert, 1755. p. 253 - Pozzolane. Terre rougeâtre qui tient lieu de sable en Italie, \& qui, mêlée avec de la chaux, fait un excellent mortier qui durcit à l'eau.

${ }^{34}$ BLONDEL, Jacques-François. Cours d'architecture..., v. VII, t. V, De la maçonnerie, Cap. V, Art. IV, p. 193. - Cette poudre est rougeâtre, \& n'est autre chose que de la terre brute mêlée avec le tuf, par les feux souterreins qui sortent des montagnes aux environs desquelles on la tire.

${ }^{35}$ [MILIZIA, Francesco]. Principii di architettura civile..., t. III, L. I, Cap. IV, p. 37.

${ }^{36}$ RIEGER, Christiano (Pe.). Elementos de toda la architectura civil: con las mas singulares observaciones de los modernos, Madrid, Joachîn Ibarra, 1763. Parte IV, Cap. I, p. 235, $\S 227$.

${ }^{37}$ FÉLIBIEN, André. Des principes de l'architecture, $3^{\mathrm{a}}$ ed., Paris, la Veuve et Jean Baptiste Coignard Fils, 1699. L. I, Cap. XII, p. 34.

${ }^{38}$ CATALOGUE DES PRODUITS minéraux du Portugal. Exposition Universelle de Londres (1862). London, C. Whiting/Beaufort House, 1862. p. 23/24.

${ }^{39}$ Região que envolve a Baía de Todos os Santos.

${ }^{40}$ Enquanto a pozolana requer a presença da água para funcionar de maneira satisfatória, o solo denominado massapê sofre muitas variações volumétricas, quando em sua presença, podendo, nestas circunstâncias, causar problemas muito grandes à edificação.

${ }^{41}$ BRANCA, Juan. Manual de arquitectura. Trad., comentários e acréscimos de Manuel Hijosa, [6ª ed.], Madrid, la Viuda de D. Joachîn Ibarra, 1790. L. I, Cap. IV, p. 9/10.

${ }^{42}$ NEGREIROS, Jozé Manuel de Carvalho. Jornada pelo Tejo..., fls. 54v.

${ }^{43} / d$., ibid., fls. 55.

${ }^{44}$ BELIDOR, Bernard Forest de. La science des ingenieurs..., L. III, Cap. IV, p. 11.

${ }^{45}$ BERTHAULT-DUCREUX. Théorie et pratique des mortiers et ciments romains. Paris, Carillion-Goeury, 1833. p.127. - Non seulement la bonne poudre de brique, mais encore la meilleure pouzzolane, se conduit avec la chaux, à peu près comme une poudre inerte, si le mortier dont elle fait partie n'est pas immergé, ou au moins maintenu à l'humidité.

${ }^{46}$ PAPACINO, Alessandro Vittorio d'Antoni. Architectura militar. Trad. de Pedro J. Xavier. Lisboa, Typ. Regia Silviana, 1795. t. IV, p. 243. 
47 COUTINHO, António de Sousa. Pozolanas, betões com pozolanas e cimentos pozolânicos, Lisboa, LNEC, 1958. Memória n. ${ }^{0}$ 136. Parte II, Cap. V, p. 53.

${ }^{48}$ /d., ibid., Apêndice I, p. 143.

${ }^{49}$ MASSAZZA, Franco; PEZZUOLI, Mario. «Some teachings of a roman concrete»..., p. 220-245. p. 222.

${ }^{50}$ Informação dada pela Dra. Marisa Laurenzi-Tabasso, do ICCROM (Roma/Itália).

${ }^{51} \mathrm{CHIARI}$, Giacomo et al. «Le malte pozzolaniche del mausoleo di Sant'Elena e le pozzolane di Torpignattara», Materiali e strutture: problemi di conservazione. Roma, L'Erma di Breschneider, 1996. n. ${ }^{\circ} 1$ (ano VI), p. 1-36.

${ }^{52}$ COUTINHO, António de Sousa. Pozolanas, betões com pozolanas e cimentos pozolânicos..., Apêndice II, p. 147.

${ }^{53} / d$., ibid., Apêndice I, p. 143/144.

${ }^{54}$ Comitê criado na Itália, há alguns anos, para discutir e padronizar os ensaios e as análises necessárias para se caracterizar de maneira satisfatória os materiais de construção, no âmbito da conservação e da restauração.

${ }^{55}$ Trass é uma pozolana natural alemã, e não um produto diverso.

${ }^{56}$ LEDUC, E., Chaux et ciments. $2^{\mathrm{a}}$ ed.. Paris, J. B. Baillière et fils, 1919. Cap. I, p. 12.

${ }^{57}$ Quando analisada em uma lâmina delgada, a pozolana é conhecida por sua estrutura fenoclástica vítrea e pelas figuras de quenching, além de sua elevada porosidade. É esta elevada porosidade que favorece as reações entre a pozolana e a cal extinta, com a formação de compostos hidráulicos.

${ }^{58}$ Tanto para obras aquáticas como para aquelas em terrenos secos.

${ }^{59} \mathrm{MASI}$, Girolamo. Teoria e pratica di architettura civile. Roma, Antonio Fulgoni, 1788. Cap. I, §I, p. 35.

${ }^{60}$ DE ROMÉ DE L'ISLE, Jean-Baptiste. Cristallographie. $2^{a}$ ed.. Paris, L'Imprimerie de Monsieur, 1783. t. II, p. 640, § III - Les pouzzolanes grises, brunes, noires, jaunâtres, rougeâtres, \& c. qui ne sont qu'un détritus de ces mêmes laves poreuses \& cellulaires, passant avec le temps à l'état ocreux ou argileux, \& dont on fait ce ciment si vanté pour les constructions sur.

${ }^{61} \mathrm{CHIARI}$, Giacomo et al. «Le malte pozzolaniche del mausoleo di Sant'Elena e le pozzolane di Torpignattara»..., p. 7.

${ }^{62}$ DE ROMÉ DE L'ISLE, Jean-Baptiste. Cristallographie..., t. II, p. 656, § III.

${ }^{63}$ VITRUVIO, Marco Lucio. Los diez libros de arquitectura, tradução de Agustín Blánquez..., L. II, Cap. V, p. 44.

${ }^{64}$ PLOMMER, Hugh. Vitruvius and later Roman building manuals, Cambridge, The University Press, 1973. p. 37.

${ }^{65}$ MARTINI, Francesco di Giorgio. «Architettura civile e militare», Trattati di architettura, ingegneria e arte militare, comentários de Corrado Maltese, Milão, II Polifilo, 1967. v. I, p. 115/116 - Si alcuno smalto, stucco o calcestruzzo overo lastrico fare vorremo, pigliarai polvare di tegole staia due, calcina staia due, scaglia di ferro staia mezzo. E questi intrisi e misti con dicozioni di bucce d'olmo. E cosi per tempo di di quindici rimenando imbeverando, dipoi smaltando quello che vuoi, colla cazzuola ogni giorno deffregando con morca d'olio o lardo per infin tanto vedrai che l'acqua rendi. 
${ }^{66}$ D'AVILER, Augustin Charles. Cours d'architecture, $3^{\mathrm{a} e d ., ~ A m s t e r d a m, ~ G e o r g e ~ G a l l e t, ~}$ 1699. t. I. p. 214.

${ }^{67}$ /d., loc. cit. - [...] il se broye avec de la chaux vive dont un tiers suffit sur deux tiers de ciment // ...ela se prepara com cal viva, da qual um terço é suficiente para os dois de ciment.

${ }^{68}$ FÉLIBIEN, André, Des principes de l'architecture..., 1699, p. 376. - [...] nostre ciment à faire du mortier, qui est de la tuile cassé [...]

${ }^{69}$ BELIDOR, Bernard Forest de. Dictionnaire portatif de l'ingénieur..., p. 65. - Ciment. C'est du tuileau concassé, qui mêlé avec de la chaux fait le meilleur mortier, \& qui est d'un bon usage pour les ouvrages fondés dans l'eau.

${ }^{70}$ BELIDOR, Bernard Forest de. La science des ingenieurs..., L. VI, p. 76 - Celui qui sera employé aux renduits \& citernaux, tant du dedans que du dessus, sera fait avec tuileaux de vieilles tuiles bien cuites, sans qu'il soit employé aucune brique; il sera bien battu, pulverisé, \& passé au tamis du boulanger, \& le mortier fait avec deux cinquiémes de chaux vive de Boulogne, \& trois cinquiemes du dit ciment, le tout bien battu, \& démêlé tous les jours consecutivement jusqu'à ce qu'il soit employé.

${ }^{71}$ Neste caso, a areia não foi, ao menos aparentemente, incluída na mistura.

${ }^{72}$ BELIDOR, Bernard Forest de. La science des ingenieurs..., L. IV, Cap. XII, p. 82 - Por exemplo, neste capítulo isto também ocorre.

${ }^{73} / d$., ibid., L. III, Cap. V. p. 15. - [...] qui ne sont point de la derniere conséquence, mais qui méritent pourtant quelqu'attention.

${ }^{74}$ BELIDOR, Bernard Forest de. Architecture hydraulique. Paris: Jombert Jeune, 1782/ 1790. t. I, Parte I, L. II, Cap. III, p. 359.

${ }^{75}$ /d., ibid., t. I, Parte I, L. II, Cap. II, Prancha 4, Fig. 5.

${ }^{76} \mathrm{O}$ material, por ser mais poroso, poderia dar origem a um pó mais macio. O problema seria a eventual presença de sais e de microorganismos, mas isto não foi mencionado nos textos consultados.

${ }^{77}$ É comum, ainda hoje, quando as telhas fissuram, a penetração da água por estes pontos, carreando os sais solúveis eventualmente depositados em sua superfície para o interior da construção.

${ }^{78}$ BLONDEL, Jacques-François. Cours d'architecture..., v. VII, t. V, Cap. V, Art. III, p. 187.

${ }^{79} \mathrm{O}$ autor não informou que uma argamassa feita simplesmente com cal e areia também estaria "viabilizada".

80 No caso, foi indicado o uso de telha moída.

${ }^{81}$ [FREMIN]. Memoires critiques d'architecture. Paris: Charles Saugrain, 1702. p. 105

82 ld., ibid., p. 108 - La pulverisation ou le concassement du ciment luy donne different configuration; il est plein de pointes, sa substance est ferme; c'est pourquoy il ne s'écrasse point sous aucun autre mineral, il en soutien tout le poids; l'abondance de ses sels \& la multiplicité de ses angles luy acquierent sa tenacité, \& ils luy fournissent des moyens plus prompts \& plus vifs de s'accrocher, c'est de cette vive adhesion, qu'est venu le proverbe, il bâtit à chaux et à ciment, parce qu'un ouvrage de cette sort est éternel.

${ }^{83}$ ASHURST, John. Mortars, plasters and renders in conservation, Londres, EASA/RIBA, 1983. p. 12. - «Pozzolana» has become a generic name for any additive which will react with 
lime to produce a hydraulic set [...] Roman builders also used bricks, tiles and pottery crushed to dust and ground iron slag as «pozzolanic additives».

${ }^{84}$ OLIVEIRA, Mário M. de; SANTIAGO, Cybèle C.; AMARAL, Allard M. do; MONTEIRO, Tersandro Paes do R.. «Soil-containing mortars in the restoration of monuments». Texto apresentado no IV ICAM, Cancún, 1995.

${ }^{85}$ OLIVEIRA, Mário M. de; SANTIAGO, Cybèle C., JESUS, José Augusto Brito de, OLIVEIRA, Teresa Cristina M. de. «Argamassas bastardas: origens e propriedades», Atas da $2^{2}$ Semana Pensando em Argamassas, Salvador, DCTM/EPUFBA, Março/96, p. 24-34. p. 29.

${ }^{86}$ CASTANHEIRA DAS NEVES, J. da P. «Estudo sobre algumas caes hydraulicas e magnesianas nacionaes», Revista de Obras Públicas e Minas, Lisboa, t. XXIII, Jul./Set. 1892, n. ${ }^{\circ} 271$ a 273. p. 207-304. p. 208.

${ }^{87}$ BELIDOR, Bernard Forest de. La science des ingenieurs..., L. III, Cap. IV, p. 12. Terrasse de Holande. C'est une espéce de poudre fait d'une terre qui se trouve assez près du bas Rhin en Allemagne \& aux environs de Cologne; on la cuit comme le plâtre; \& on la reduit ensuite en poudre. Cette poudre est excellente pour la composition du mortier quand on veut bâtir dans l'eau.

${ }^{88}$ BELIDOR, Bernard Forest de. Dictionnaire portatif de l'ingénieur..., p. 306.

${ }^{89}$ BELIDOR, Bernard Forest de. La science des ingenieurs..., L. III, Cap. V, p. 16.

${ }^{90}$ BLONDEL, Jacques-François, Cours d'architecture..., v. VII, t. V, Cap. V, Art. IV, p. 193. [...] une pierre de couleur grisâtre, qu'on trouve près du Bas-Rhin, en Allemagne, \& dans les Pays-Bas. Celle-ci si prépare comme le plâtre, \& on l'écrase ensuite pour la détremper avec de la chaux.

${ }^{91}$ [MILIZIA, Francesco]. Principii di architettura civile..., t. III, p. 41. -Ne' contorni di Colonia e del basso Reno si usa una specie di polvere grigia, detta terrazza di Olanda, e si fa di una terra, che si cuoce e si macer come il gesso [...] Anche i ciotolli di qualunque luogo roventati, e ridotti in polvere, danno una specie di terrazza d'Olanda, che unita colla calce fa un ottimo cemento.

${ }^{92}$ LEDUC, E.. Chaux et ciments, $2^{a}$ ed.. Paris, J. B. Baillière et fils, 1919. Cap. I, p. 12.

${ }^{93}$ BELIDOR, Bernard Forest de. La science des ingenieurs..., L. III, Cap. V, p. 16 // BELIDOR, Bernard Forest de, Dictionnaire portatif de l'ingénieur..., p. 54. - Cendrée de Tournai. Les environs de Tournai fournissent une pierre trés-dure, dont on fait une chaux excellente. Quand cette pierre est dans le four, il s'en détache de petites parcelles qui tombent sous la grille, òu elles se mêlent avec la cendre du charbon de terre; et comme cette cendre n'est autre chose que de petites parcelles de houille calcinée, c'est le mêlange qui s'en fait qui compose ce qu'on appelle cendrée de Tournai, qui se débite telle qu'on la tire du four.

94 [MILIZIA, Francesco]. Principii di architettura civile..., t. III, p. 41.

${ }^{95}$ BOUILLET, M. N.. Dictionnaire universel des sciences, des lettres et des arts..., p. 289, verbete cendrée. - [ ...] mélange de pierre à chaux calcinée et de cendres de charbon de terre, qui sert de ciment pour les coupelles et qu'on emploi aussi quelquefois comme ciment hydraulique.

${ }^{96}$ Análise química e análise petrográfica, por exemplo. 


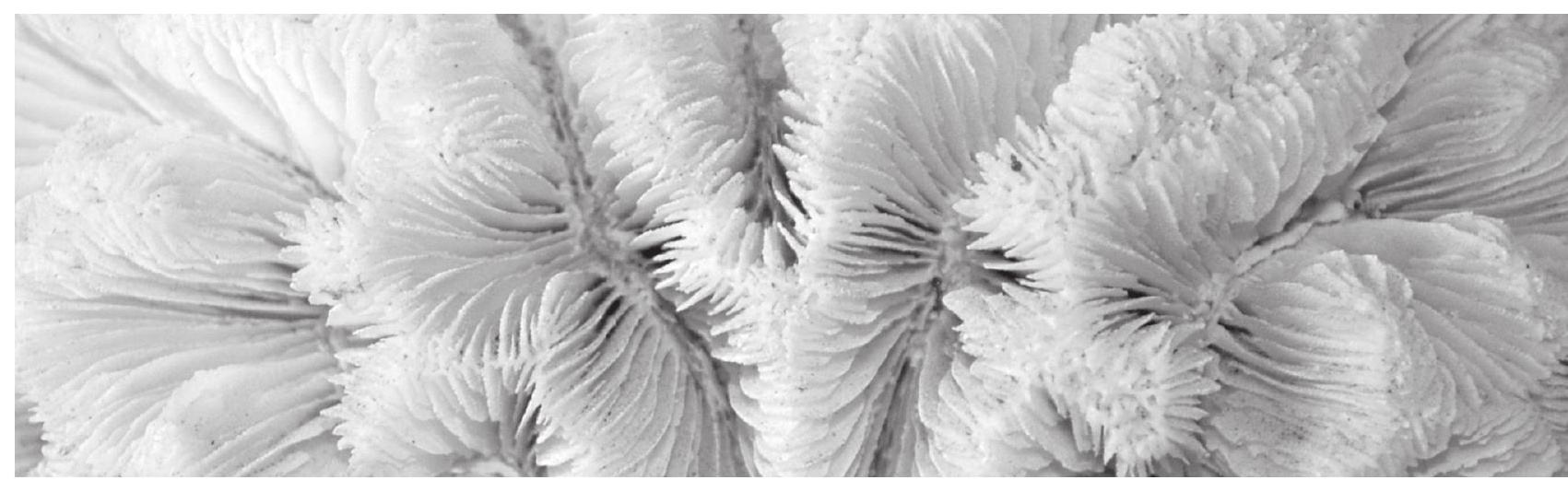

\section{Considerações finais}


Pode-se afirmar, sem a menor sombra de dúvida, que o texto de Vitrúvio foi a referência mais importante para todos os autores que abordaram o assunto das argamassas e seus materiais constituintes, até o século XVIII. Por outro lado, o texto de Alberti, o primeiro tratado impresso de arquitetura, bastante citado pelos autores estudados, também merece destaque ${ }^{1}$. Verificou-se, igualmente, a grande importância dos textos elaborados pelos engenheiros militares, principalmente nos séculos XVII e XVIII, para o conhecimento dos materiais de construção. No caso dos livros, foram textos muito difundidos ${ }^{2}$, mas documentos de caráter diversos também consistem em uma boa fonte de informações sobre o assunto. Bastante útil, especialmente para se ter como comparar a teoria e a prática.

Uma outra constatação que se pôde fazer foi que alguns autores repetiram, durante muito tempo, informações sem comprovação histórica ou científica, propagando, assim, falsidades que, por vezes, passaram a ser consideradas praticamente como verdades absolutas. Em alguns casos, mesmo após ter sido demonstrado que a interpretação de certos fatos estava errada, sob o ponto de vista da ciência, a informação continuou a ser transmitida como verdadeira, o que agravou ainda mais a situação.

Apesar de todos estes senões, ressalta-se que o espírito de investigação pôde ser sentido na grande parte dos textos consultados. Já que não se dispunha, há alguns séculos, de conhecimentos suficientes para averiguar a qualidade das argamassas por meio de ensaios laboratoriais, foram desenvolvidos, por intermédio da observação, testes 
empíricos. Muitos destes testes são, inclusive, utilizados até hoje, em certas circunstâncias, para se ter uma idéia acerca do comportamento do material ${ }^{3}$.

Durante séculos, muitos ensinamentos foram simplesmente repetidos pelos tratadistas, sem que fossem ao menos questionados dentro da boa prática cartesiana. Isto porque a ciência não havia avançado, ainda, a ponto de alterar conceitos então tidos como verdadeiros. Nem havia proporcionado conhecimentos e/ou equipamentos para a realização de determinados ensaios que pudessem ratificar, ou retificar, o que era tido como correto, anteriormente.

Até hoje, fato similar ainda ocorre, felizmente, com uma menor freqüência. Contudo, muitas informações erradas acerca dos materiais de construção, de maneira geral, continuam a ser passadas aos leitores. Normalmente isto é feito sem que sejam citadas as fontes bibliográficas, ou que o autor se reporte a resultados de ensaios laboratoriais ou observações sistemáticas.

Nos textos consultados, foi possível encontrar informações corretas sobre as características das argamassas, ou mesmo sobre o seu comportamento, porém em muitos casos com justificativas erradas. Isto demonstra a perspicácia dos autores para observar os fenômenos que ocorriam quando o material era aplicado, incluindo os efeitos nocivos do meio ambiente, na degradação das obras. Hoje, apesar de ter-se apoio da ciência e as justificativas para determinadas características e comportamento das argamassas serem conhecidas, muitas vezes os profissionais que trabalham na construção civil não se preocupam com estes tipos de problemas ou deles não se apercebem, e a durabilidade da construção é reduzida. Ou seja, mesmo com todo o apoio tecnológico atualmente disponível, por vezes a falta de cuidado despendida no preparo e na aplicação das argamassas é responsável pela menor durabilidade das construções.

A preocupação com a qualidade dos materiais e com a execução da obra somente passou a ser mais efetiva nos últimos anos da década de noventa do século XX, tendo em vista as exigências dos consumidores e os programas de qualidade total que começaram a ser implantados. Hoje, alguns materiais de construção de qualidade duvidosa, porém, são ainda freqüentemente utilizados apenas pelo seu custo reduzido. 
À medida que é aprofundado, na bibliografia anterior ao século XIX, o estudo das argamassas, passa-se a compreender melhor os problemas com os quais se tem que deparar quando da conservação e da restauração de um monumento. No caso da sua composição, por exemplo, verificase que se torna cada vez mais difícil chegar a uma conclusão definitiva quando de sua análise. Em alguns casos, o uso de técnicas de investigação complementares pode determinar a presença de um certo componente, como no caso da individualização da pozolana. O problema residiria em como conseguir fazer a dosagem correta dos materiais empregados.

Ainda com relação à determinação dos traços originalmente utilizados nas argamassas, é praticamente impossível tirar conclusões positivas acerca da sua composição quando do uso de aditivos orgânicos, que sofrem alterações com o passar dos anos, ou mesmo quando componentes como a Mortier-Loriot tiverem sido acrescentados à mistura ${ }^{4}$.

No caso do uso de cinzas de Tournai, por exemplo, talvez também não se viabilize a constatação da sua presença, mas apenas seja possível a determinação da hidraulicidade da mistura. Se esta afirmação for verdadeira, não se poderia recompor o traço original da argamassa.

Outros fatores também contribuem para a grande dificuldade de determinação dos traços originais das argamassas: os valores recomendados nos textos consultados variaram muito ${ }^{5}$ foram muitas as adições citadas ao longo dos séculos; por vezes foram usados determinados constituintes em substituição à areia; os tipos de cal e areia empregados variaram; a maneira de preparar tais argamassas igualmente variou. Além disso, também foram mencionadas, embora raramente, argamassas compostas unicamente por cal e óleo.

Uma outra dificuldade, quando é tentada a reconstituição do traço das argamassas, é que, caso a areia usada tenha sido carbonática, o resultado do ensaio é falseado: com a liberação de gás carbônico, em decorrência da decomposição da areia, o valor correspondente ao percentual de carbonatos é atribuído à cal. Aumenta-se, pois, o percentual teórico de cal e o de areia sofre redução. Além deste problema, tem-se que, quando determinada porção de argila é eventualmente detectada em testes de laboratório, não se pode afirmar com segurança se seria proveniente da areia ou da cal, como impureza, ou se teria sido usada 
como ingrediente deliberadamente introduzido na mistura ${ }^{6}$. O certo é que a argila é um ingrediente detectado freqüentemente em argamassas antigas. Quanto a este aspecto, concorda-se com Michel Frizot ${ }^{7}$.

Alguns dos autores consultados mencionaram que a variação dos componentes de uma argamassa dependia tanto da qualidade dos materiais, quanto da finalidade à qual se destinava a mistura e a disponibilidade local. Contudo, não consideravam a granulometria, nem o inchamento da areia, assim como não entendiam o comportamento químico dos diversos ingredientes da mistura entre si. Às vezes, por falta de conhecimentos, tanto teóricos, quanto práticos, limitavam-se a repetir o que outros autores já haviam dito, sem refletir se as circunstâncias de suas recomendações eram as mesmas. Ou então, aventuravam-se a tecer considerações mirabolantes, baseadas em fatos impossíveis de serem comprovados nos períodos em que viveram.

Entretanto, não é por certos autores terem emitido opiniões hoje consideradas como absurdas sobre o comportamento, ou a constituição, de alguns materiais de construção, que seus textos deixam de ser importantes, ou interessantes, para a época atual. Valeria a pena, por exemplo, serem publicados os códices Jornada pelo Tejo e Additamento: ao livro Jornada pelo Tejo, da autoria de Jozé Manuel de Carvalho Negreiros, que apesar de apresentarem inúmeros trechos transcritos do texto Problema de architectura civil, de Mathias Ayres Ramos da Sylva de Eça, são textos interessantes, bem estruturados e que contêm algumas informações originais.

Constatou-se que muitos dos problemas que afetaram as construções, e por vezes ainda podem ser notados, tanto em monumentos históricos, quanto em construções atuais, foi que, mesmo tendo-se o conhecimento de determinados fatores de sua degradação, estes eram eventualmente relegados a segundo plano, em detrimento de outros interesses.

Para finalizar, sugerem-se diretrizes que podem ser seguidas em trabalhos futuros:

- Dar continuidade aos ensaios de caracterização de cais provenientes de organismos marinhos, materiais que apresentam constituição muito variável, de um local para o outro.

- Analisar o comportamento de argamassas quando da presença de diferentes aditivos orgânicos. No caso, seria necessário escolher 
alguns aditivos, preparar corpos de provas e ensaiá-los, efetuando, paralelamente, o estudo de amostras de argamassas provenientes de monumentos históricos;

- Tentar descobrir a presença de cinzas de Tournai em alguma antiga especificação para as obras de determinado monumento daquela região, e analisar várias amostras, ou mesmo preparar o material conforme as receitas de Belidor, J. F. Blondel e Milizia, avaliando-o posteriormente. Na realidade, seria interessante fazer todas as avaliações, para que se tivesse um melhor conhecimento dos tipos de argamassas outrora utilizados, especialmente com a finalidade de intervir em monumentos a serem conservados ou restaurados. Fato similar é sugerido no caso das argamassas contendo outros ingredientes até então pouco estudados;

- Verificar o índice de saponificação de argamassas de cal e óleo, por meio de ensaios químicos, de modo a ter-se noção do seu comportamento quando empregado na vedação de tubos ou em rejuntamento;

- Observar eventuais diferenças no comportamento das argamassas, caso o ciment seja proveniente de pó de tijolo ou pó de telha. Podese testar, inclusive, material proveniente de telhas e tijolos usados e novos.

\section{Notas}

${ }^{1}$ Seu autor, grande arquiteto, era muito erudito, de modo que o seu tratado, de maneira geral, é mais claro e mais completo que o de Vitrúvio.

${ }^{2}$ Em Portugal, por exemplo, quando os textos não eram redigidos originalmente no idioma português, os próprios militares encarregavam-se da tradução daqueles que lhes interessavam.

${ }^{3}$ Isto é recomendado como uma verificação mais expedita quando do recebimento dos materiais de construção, na obra, principalmente se há suspeita da sua má qualidade.

${ }^{4}$ Sendo esta argamassa preparada com uma pasta de cal e areia, ou cal e pó cerâmico, traço 1:2, misturada pela segunda vez com determinada proporção de cal viva em pó, não se teria condições, através dos percentuais encontrados para os diversos constituintes por meio de ensaios e análises laboratoriais, de determinar-se a sua composição original.

${ }^{5}$ Pelo menos de 1:0,5 a 1:7, no caso de argamassas simples de cal e areia.

${ }^{6}$ Geralmente, quando a argila é encontrada em pequenas quantidades, considera-se que entrou na mistura como impureza. 
${ }^{7}$ FRIZOT, Michel. «L'analyse des mortiers antiques », Mortars, cements and grouts used in the conservation of historic buildings (anais do simpósio de Roma, 3-6.11.1981). Roma: ICCROM, 1982. p. 331-339. p. 334. 


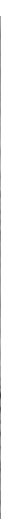

Referências 


\section{Fontes manuscritas}

AHU, CA, SP, v. IX, Cx. 44, n. ${ }^{\circ}$ 44, 10/Ago/1798. Of. de António Manuel de Melo Castro e Mendonça para D. Rodrigo de Sousa Coutinho.

ANTT, Papéis do Brasil, avulsos 3, n. ${ }^{\circ}$ 6, 13/8/1551. Fundação da Bahia, profissões, assuntos interessantes.

BAj, cota: 51-IX-21, p. 40. Carta sobre fortificação de Angola.

COUTO, Mattheus do (o Velho). Tractado de architectura qué leo o mestre, e archito Mattheus do Couto o Velho no anno de 1631, [Lisboa], 1631. Cód. F. 7752 (BNL).

NEGREIROS, Jozé Manuel de Carvalho. Additamento ao livro Jornada pelo Tejo, [Lisboa], Cód. 3758-62 (BNL), 1797. 5 v.

NEGREIROS, Jozé Manuel de Carvalho. Jornada pelo Tejo: dividida em 12 dias em cada um dos quais se trata de várias matérias concernentes à arquitectura civil e seus pertences, [Lisboa], Cód. 80 (AHM), 1792.

SAVARY. Diccionario de commercio e industria, trad. de Alberto Jacqueri Salles. [Lisboa], Cód. MEPAT, anterior a 1813. 3 v.

VELLOZO, Diogo da Sylveyra. Architectura militar ou fortificacão [sic] moderna, Pernambuco, Cód. 49-III-3 (BAj), 1743.

\section{Fontes impressas}

ALBERTI, Leon Battista. De re ædificatoria (Florença, 1495), trad. de Giovanni Orlandi, introdução. e notas de P. Portoghesi, ed. bilingüe latim/italiano, L'archittetura. Milão: II Polifilo, 1966. 2 v.

ANDRADE, Rodrigo M. F. Artistas coloniais. RJ: MEC, 1958. Apud SIMAS FILHO, Américo. A propósito de Luís Dias. Salvador: FGM, 1998. 
ASHBY. Architecture of ancient Rome. Londres: 1927. Apud PLOMMER, Hugh. Vitruvius and later Roman building manuals. Cambridge: The University Press, 1973.

ASHURST, Jonh. Mortars, plasters and renders in conservation. Londres: EASA/RIBA, 1983.

AZEVEDO FORTES, Manoel de. O engenheiro português (Lisboa, Manoel Fernandes da Costa, 1729), fac-símile. Lisboa: Direcção da Arma de Artilharia, 1993. t. II.

BELIDOR, Bernard Forest de. Architecture hydraulique, ou l'art de conduire, d'élever et de ménager les eaux pour les différens besoins de la vie. Paris: Jombert Jeune, 1782/1790.

BELIDOR, Bernard Forest de. Dictionaire portatif de l'ingénieur. Paris: Charles-Antoine Jombert, 1755.

BELIDOR, Bernard Forest de. La science des ingenieurs, dans la conduite des travaux de fortification et d'architecture civile. Paris: Claude Jombert, 1729.

BERTHAULT-DUCREUX. Théorie et pratique des mortiers et ciments romains. Paris: Carillion-Goeury, 1833.

BLONDEL, Jacques-François. Cours d'architecture: ou traité de la décoration, distribution \& construction des bâtiments; contenant les leçons données en 1750, \& les années suivantes, par J.F. Blondel, architecte, dans son École des Arts. Paris: Desaint, 1771-1777. 9 v.

BONAZZI, Achile ; FIENI, Laura. «Uso e fortuna delle malte d'argilla nell'Italia settentrionale: prime ricerche su Cremona», Revista Trimestral di Restauro. Milão: Franco Angeli, 1995, n. ${ }^{\circ} 1$, p. 44-52.

BONNAMI, H., Fabrication et controle des chaux hydrauliques et des ciments. Paris: Gauthiers-Villars et fils, 1888.

BOUILLET, M. N. Dictionnaire universel des sciences, des lettres et des arts. $12^{\mathrm{a}}$ ed. Paris: Hachette et $\mathrm{C}^{\mathrm{ie}}, 1877$ (1 ${ }^{\mathrm{a}}$ ed., 1854).

BRANCA, Giovanni. Manuale d'architettura, comentários e acréscimos de Giovanni Soli, $5^{a}$ ed. Modena: Soc. Tipografica, 1789.

BRANCA, Juan. Manual de arquitectura, trad., comentários e acréscimos de D. Manuel Hijosa, [6ª ed.]. Madrid: Viuda de D. Joachîn Ibarra, 1790.

BRANCO, J. Paz. Manual do pedreiro. Lisboa: LNEC, 1981.

BRISEUX, Charles Etienne. L'art de bâtir des maisons de campagne: où I'on traite de leur distribuition, de leur construction, \& leur décoration. Paris: Prault Pere, 1743. 
BULLET, Jean-Baptiste. L'architecture pratique, qui comprend le detail du toisé, \& du devis des ouvrages de massonnerie, charpenterie, menuiseries, serrurerie, plomberie, vitrerie, ardoise, tuile, pavé de grais \& impression. Paris: Ch. J. B. Delespine \& Jean-Th. Herissant, 1741 (1 ${ }^{\text {a }}$ ed.: anterior a 1729).

CAPRA, Alessandro. La nuova architettura civile e militare (Cremona: Pietro Ricchini, 1717), fac-símile, Biblioteca di Architettura, Urbanistica, Teoria e Storia, Col. dirigida por Roberto Fregna e Giulio Nanetti, n. ${ }^{\circ}$ 14, Sala Bolognese, Arnaldo Forni, 1987. t. I (La nuova architettura famigliare).

CARNEIRO, Edison. A cidade do Salvador (1549), $2^{a}$ ed., Salvador, Econômico e Administração, s.d.

CASTANHEIRA DAS NEVES, J. da P. «Estudo sobre algumas caes hydraulicas e magnesianas nacionaes», Revista de Obras Públicas e Minas. Lisboa, t. XXIII, Jul/Set 1892, n. ${ }^{\circ} 271$ a 273. p. 207-304.

CASTANHEIRA DAS NEVES, J. da P. «Memoria sobre as investigações experimentaes e ensaios de resistencia dos materiaes de construcção", Revista de Obras Públicas e Minas, Nov./Dez. 1893, t. XXIV, p. 497-522.

CASTRO, Alberto Gomes de; LIMA, António Vasconcelos. Ciência e tecnologia dos materiais. Gondomar: Universidade de Trás-os-Montes e Alto Douro, 1988.

CATALOGUE DES PRODUITS minéraux du Portugal: Exposition Universelle de Londres (1862). London: C. Whiting/Beauford House, 1862.

CATANEO, Pietro. I quattro primi libri di architettura (Veneza, Figliuoli di Aldo, 1554), fac-símile. Ridgewood: The Gregg Press Incorporated, 1964.

CATON, M. Porcius. «L'economie rurale», SABOUREUX DE LA BONNETRIE, M., Traduction d'ancien ouvrages latins: relatifs a l'agriculture et a la médecine vétérinaire, avec des notes. Paris, P. Fr. Didot, le Jeune, 1771.

CHIARI, Giacomo et al. «Le malte pozzolaniche del mausoleo di Sant'Elena e le pozzolane di Torpignattara», Materiali e strutture: problemi di conservazione, Roma, L'Erma di Breschneider, 1996. n. ${ }^{\circ}$ (ano VI), p. 1-36.

[CORMONTAIGNE], Architecture militaire: ou l'art de fortifier, qui enseigne d'une manière courte \& facile la construction de toutes sortes de fortifications régulierès \& irrégulières. Haia: Jean Neaulme et Adrien Moetjens, 1741.

COUTINHO, António. Pozolanas, betões com pozolanas e cimentos pozolânicos. Lisboa: LNEC, 1958, Memória n. ${ }^{0} 136$.

D'AVILER, Augustin Charles. Cours d'architecture: qui comprend les ordres de Vignole, avec les commentaires, les figures \& descriptions de ses plus beaux bâtimens, \& ceux de Michel-Ange. $3^{\mathrm{a}}$ ed. Amsterdam: George Gallet, 1699. t. I, t. II: Dictionnaire d'architecture. 
DAVEY, Norman. A history of building materials. Londres: Phoenix, 1961. DE L'ORME, Philibert. Le premier tome de l'architecture (Paris, Frederic Morel, 1567), fac-símile, apres. de J. M. Pérouse de Montclos. Paris: Léonce Laget, 1988.

DE ROMÉ DE L'ISLE, Jean-Baptiste. Cristallographie: ou description des formes propes a tous les corps du regne minéral, dans l'état de combinaison saline, pierreuse ou métallique, avec figures \& tableaux synoptiques de tous les cristaux connus, $2^{\mathrm{a}}$ ed. Paris: L'Imprimerie de Monsieur, 1783.

DE VILLE, Antoine. Les fortifications: avec l'ataque \& la defence des places. Lyon, Phillipe Borde, 1641.

DOMASLOWSKI, W. «The properties of lime and cement mortars modified by metakaolinite", Anais do 8th International Congress on Deterioration and Conservation of Stone, Berlim, 30.9-4.10.96. Berlim: Josef Riederer, 1996. v. III, p. 1529-1534.

DOURSTHER, Horace. Dictionnaire universel des poids et mesures anciens et modernes, Bruxelas, s.n., 1840. Apud SANTOS, Vitor Manuel V. Lopes dos, O sistema construtivo pombalino em Lisboa em edifícios urbanos agrupados de habitação colectiva. Lisboa, Fac. de Arquitectura da Universidade Técnica de Lisboa, 1994. Tese de doutorado. v. II,

DUHAMEL DU MONCEAU, Henri-Louis. De l'exploitation des bois: ou moyens de tirer un parti avantageux des taillis, demi-futaies et hautes-frutaies, et d'en faire une juste estimation, avec la description des arts qui se pratiquent dans les forêts, faisant partie du traité complet des bois \& des foreste. Paris: H. L. Guerin \& L. F. Delatour, 1764.

EÇA, Mathias Ayres Ramos da Sylva de. Problema de architectura civil. Lisboa: Antonio Rodrigues Galhardo, 1777 (1ª ed: 1770) - Publicação póstuma.

FÉLIBIEN, André. Des principes de l'architecture: de la sculpture, de la peinture, et des autres arts qui en dependent. Avec un dictionnaire des termes propes a chacun de ces arts, $3^{\mathrm{a}}$ ed. Paris: la Veuve et Jean Baptiste Coignard Fils, 1699.

FERREIRA, Carlos Augusto Pinto. Engenheiro de algibeira: ou compendio de formulas e dados praticos para uso dos engenheiros mechanicos, militares ou civis, 5ª ed. Lisboa: A. M. Pereira/Livraria Editora, 1903.

FILARETE, Antonio Averlino, O. Trattado di architettura (texto aos cuidados de Anna Maria Finoli, Liliana Grassi), Milão: II Polifilo, 1972, Col. Trattati di architettura, aos cuidados de P. Portoghesi e R. Bonelli. 2 v.

[FREMIN]. Memoires critiques d'architecture. Paris: Charles Saugrain, 1702. 
FRIZOT, Michel. «L'analyse des mortiers antiques: problemes et resultats», Mortars, cements and grouts used in the conservation of historic buildings (anais do simpósio de Roma, 3-6.11.1981), Roma, ICCROM, 1982. p. 331339.

FRIZOT, Michel. Mortiers et enduits peints antiques, ètude technique et archéologique. Dijon: Université de Dijon, 1975. Publicação do Centro de Investigação sobre as Técnicas Greco-Romanas, n. ${ }^{\circ} 4$.

FURLAN, Vinicio. «Experiences pratiques avec des crepis a base de chaux», Mortars, cements and grouts used in the conservation of historic buildings (anais do simpósio de Roma, 3-6.11.1981), Roma, ICCROM, 1981, p. 9-18. FUSTER, José Maria; MELENDEZ, Bermudo. Geologia, $3^{a}$ ed. (corrigida e ampliada, $2^{a}$ tiragem). Madrid: Paraninfo, 1975.

GIULIANI, Cairoli Fulvio. L'edilizia nell'Antichità, $4^{\mathrm{a}}$ impressão. Roma: NIS, 1995 (1 ${ }^{\mathrm{a}}$ ed.: 1990).

GNADLINGER, João. Redescobrindo a cal para construir cisternas. Juazeiro: Fonte Viva, [1999].

GOMES, Adailton Oliveira; VALOIS, João Guilherme Cerqueira. «Argamassas com adição utilizadas na região metropolitana de Salvador», Revista da Jornada Profo Hernani Sobral, ed. única, Feira de Santana, 1994, p. 49-52.

GUIMARÃES, José Epitácio Passos. A cal: fundamentos e aplicações na engenharia civil. São Paulo: Pini, 1997.

GURRIERI, Francesco. «Piero Sanpaolesi, il restauro come scienza», Piero Sanpaolesi: il restauro, dai principi alle tecniche. Catálogo da VI Assembléia Geral do ICOMOS. Florença: Fac. de Architettura dell'Università degli Studi di Firenze/Regione Toscana (Dip. Istr. e Cultura), 1981, p. 7-12.

HERATH, J. W.. «Lime industry in Sri Lanka», HILL, Neville; HOLMES, Stafford; MATHER, David. Lime and other alternative cements, Exeter, ITP, 1992, Cap. VII, p. 56-64.

HILL, Neville; HOLMES, Stafford; MATHER, David. Lime and other alternative cements, Exeter, Intermediate Technology Publications, 1992.

JOMBERT, Charles-Antoine. Architecture moderne, òu l'art de bâtir bien pour toutes sortes de personnes. Paris: C. A. Jombert, 1764 (1 $1^{a}$ edição: 1728).

KINGERY, W. David; VANDIVER, Pamela; PRICKETT, Marta; «The beginnings of pyrotechnology. Part II: Production and use of lime and gypsum plaster in the pre-pottery neolithic near east», Journal of field archaeology, v. XV, p. 219-243, 1988. 
LE CHATELIER, H.. Recherches éxperimentales sur la constitution des mortiers hydrauliques. Paris: Vve Ch. Dunod, 1904.

LEÃO, Zelinda Margarida A.N.. Guia para identificação dos corais do Brasil. Salvador: PPPG/UFBA, 1986.

LEDUC, E. Chaux et ciments, $2^{\mathrm{a}}$ ed. Paris: J. B. Baillière et fils, 1919.

LOSADA, Manuel. Critica, y compendio especulativo-practico de la architectura civil. Madrid: Antonio Marin, 1740, t. I.

LUNA, Maria Isabel. "Consolidation of traditional plasters: a laboratory research", Atas da $7^{a}$ Conferência Internacional sobre o Estudo e Conservação da Arquitectura de Terra - Silves, 24-29/10/93. Lisboa: DGEMN, 1993, p. 410-416.

MARTIN, Roland. Manuel d'architecture grecque. Paris: A. et J. Picard et Cie, 1965. v. I (Matériaux et Techniques). Collection des manuels d'archéologie et d'histoire de l'art.

MARTINI, Francesco di Giorgio. Trattati di architettura ingegneria e arte militare, transcrição de Livia Maltese Degrassi, comentários de Corrado Maltese. Milão: II Polifilo, 1967. Classici italiani di scienze techniche e arti, v. II e III.

MASI, Girolamo, Teoria e pratica di architettura civile: per istruzione della gioventù specialmente romana. Roma: Antonio Fulgoni, 1788.

MASSAZZA, Franco; PEZZUOLI, Mario. "Some teachings of a roman concrete», Mortars, cements and grouts used in the conservation of historic buildings (anais do simpósio de Roma, 3-6.11.1981), Roma, ICCROM, 1982.

McKEE, Harley. «Commentary: masonry and masonry products: mortar, plaster/stucco and concrete», Preservation and conservation: principles and practices (anais da conferência americana international de Williamsburg, 10-16 de Setembro, 1972). Washington: The Preservation Press, 1976.

[MILIZIA, Francesco]. Principii di architettura civile. Bassano: Remondini di Venezia, 1785. t. I e III.

MORAIS SILVA, António de. Grande dicionário da língua portuguesa, 10ª ed. (revista, corrigida e atualizada por Augusto Moreno, Cardoso Júnior e José Pedro Machado). Lisboa: Confluência, 1955. v. VIII.

MOREIRA, Rafael. Um tratado português de arquitectura do século XVI. Lisboa, Faculdade de Ciências Sociais e Humanas, 1982. Dissertação de mestrado.

NBR-6472 - Cal - Determinação do resíduo de extinção. Rio de Janeiro: ABNT, Jun./1993. 
NBR-7220 - Agregados - Determinação de impurezas orgânicas húmicas em agregado miúdo. Rio de Janeiro, ABNT, Ago./1987.

NBR-9777 - Agregados - Determinação da absorção de água em agregados miúdos. RJ, ABNT, Março/1987.

NBR-13528 - Revestimento de paredes e tetos de argamassa inorgânica Método de ensaio. Rio de Janeiro, ABNT, 1995.

NERO, José Manuel G.; APPLETON, Júlio António; GOMES, Abdias M.. «As argamassas tradicionais no parque edificado de Lisboa: uma colaboração para o seu conhecimento", Atas do $2^{\circ}$ ENCORE. Lisboa, 27/ 6-1/7/1994, Lisboa, LNEC, v. I, p. 221-232.

OLIVEIRA, Mário Mendonça de. «A prancheta, o canteiro e a durabilidade do construído", Revista RUA. Salvador: MAU, 1989, v. II, n. ${ }^{\circ}$ 3, p. 117-131.

OLIVEIRA, Mário M. de; SANTIAGO, Cybèle C.; AMARAL, Allard M. do; MONTEIRO, Tersandro Paes do R.. «Soil-containing mortars in the restoration of monuments», Texto apresentado no IV ICAM, Cancún, 1995.

OLIVEIRA, Mário Mendonça de; SANTIAGO, Cybèle Celestino; JESUS, José Augusto Brito de; OLIVEIRA, Teresa Cristina M. de. «Argamassas bastardas: origens e propriedades", Anais do $1^{a}$ Simpósio Brasileiro de tecnologia das Argamassas. Goiânia: UFG/ANTAC, Ago/95, p. 43-52.

OLIVEIRA, Mário Mendonça de; SANTIAGO, Cybèle Celestino; JESUS, José Augusto Brito de; OLIVEIRA, Teresa Cristina Menezes de. "Argamassas bastardas: origens e propriedades», Anais da $2^{a}$ Semana Pensando em Argamassas. Salvador: DCTM/EPUFBA, Março/96, p. 24-34.

OLIVEIRA, Mário Mendonça de; SANTIAGO, Cybèle Celestino; LEAL, João Legal. Rudimentos para oficiais de conservação e restauração. Rio de Janeiro: ABRACOR, 1996.

OLIVEIRA, Teresa Cristina M. de. "Argamassas bastardas" e suas características físicas, químicas e tecnológicas. Salvador, Faculdade de Arquitetura da UFBA, 1995. Dissertação de mestrado.

OLIVEIRA, Valério Martins de. Advertencias aos modernos: que aprendem os officios de pedreiro e carpinteiro, offerecidas ao Senhor S. Joseph, patrono do mesmo officio, venerado na sua parochial igreja desta cidade de Lisboa, Lisboa, Antonio da Sylva, 1748.

PALLADIO, Andréa. I quattro libri dell'architettura (Veneza, Dominico de'Franceschi, 1570), fac-símile sob a responsabilidade de Ulrico Hoepli Editore Libraio. Milão: Ulrico Hoepli, 1968.

PAPACINO, Alessandro Vittorio d'Antoni. Architectura militar: na qual se trata dos princípios fundamentaes da fortificação, trad. de Pedro Joaquim Xavier. Lisboa: Typographia Regia Silviana, 1795. t. IV. 
PAPACINO, Alessandro Vittorio d'Antoni. Institutions physico-mechaniques, à l'usage des Écoles Royales d'Artillerie et du Genie de Turin. Strasbourg: Bauer \& Treuttel, 1777. t. IV.

PATTE, Pierre. Mémoires sur les objets les plus importans de l'architecture. Paris: Rozet, 1769.

PERONI, S. et al. «Lime based mortars for the repair of ancient masonry and possible substitutes», Mortars, cements and grouts used in the conservation of historic buildings (anais do simpósio de Roma, 3-6.11.1981), Roma: ICCROM, 1982, p. 63-99.

PETRUCCI, Eládio G. R.. Materiais de construção, $8^{a}$ ed. Porto Alegre: Globo, 1987.

PFEFFINGER. Fortificaçam moderna: ou recompilaçam de differentes methodos de fortificar, trad. de Manoel da Maia. Lisboa: Officina Real Deslandesiana, 1713.

PLINIO (o Antigo). Historia naturale de G. Plinio Secondo, trad. de Ludovico Domenichi. Venezia: Gabriel Giolito de Ferrari, 1561-1568.

PLINIUS, C. Secundus, Natural history. Livros XXXVI-XXXVII, publicação bilingüe sob a resp. de D. E. Eichholtz. Londres: Oxford Press, 1962. The Loeb Classical Library, v. X.

PLOMMER, Hugh. Vitruvius and later roman building manuals. Cambridge: The University Press, 1973.

REBOUÇAS, André. Guia para os alumnos da $1^{a}$ cadeira do $1^{\circ}$ anno de Engenharia Civil. Rio de Janeiro: Typographia Nacional, 1885.

REIS, Maria Olinda Braga; SILVA, António Santos. «Caracterização química e microestrutural de argamassas antigas", Atas do $2^{\circ}$ ENCORE. Lisboa, 27/6-1/7/1994. Lisboa: LNEC, v. I, p. 319-330.

RIEGER, Christiano (Pe.). Elementos de toda la architectura civil: con las mas singulares observaciones de los modernos. Madrid: Joachîn Ibarra, 1763.

RODOLICO, Francesco. Le pietre della città d' Italia, $2^{\mathrm{a}}$ ed.. Florença: Felice le Monnier, 1953.

[RODRIGUES, António]. [Tratado de arquitectura], [Lisboa], Cód. 3675 (BNL), [séc. XVI], MOREIRA, Rafael. Um tratado português de arquitectura do século XVI. Lisboa, Faculdade de Ciências Sociais e Humanas, 1982. Dissertação de mestrado.

RODRIGUES, Francisco de Assis. Diccionario technico e historico de pintura, esculptura, architectura e gravura. Lisboa: Imprensa Nacional, 1875. 
RODRIGUES, Maria João Madeira; SOUSA, Pedro Fialho de; BONIFÁCIO, Horácio Manuel Pereira. Vocabulário técnico e crítico de arquitectura, $2^{\mathrm{a}}$ ed. (rev.). Coimbra: Quimera, 1996.

SAGREDO, Diego de. Medidas del romano (Toledo, 1549), fac-símile, introd. de Fernando Manás e Agustin Bustamante. Madrid: Instituto de Conservación y Restauración de Bienes Culturales, 1986.

SANTIAGO, Cybèle Celestino. Aditivos orgânicos em argamassas antigas. Salvador, UFBA, 1992. Dissertação de mestrado.

SANTIAGO, Cybèle C.; KORN, Maria da Graça A.; AMARAL, Allard M. do; OLIVEIRA, Mário M. de. "Estudo comparativo entre cais usadas em argamassas antigas", Anais do congresso "Quarry - Laboratory - Monument" International Congress - Pavia 2000. Setembro, 26-30, 2000. Pavia, G. Calvi e U. Zezza.V.1. p.551-516.

Anais do 8th International Congress on Deterioration and Conservation of Stone, Berlim, 30.9-4.10.96, Berlim, Josef Riederer, 1996. v. III, p. 15291534.

SANTIAGO, Cybèle Celestino. O solo como material de construção. Ilustrações de Adamastor C. Santana. Salvador: EDUFBA, 2001. Coleção Pré-textos.

SANTIAGO, Cybèle Celestino. Estudo dos Materiais de Construção de Vitrúvio até ao século XVIII: uma visão crítica interpretativa à luz da ciência contemporânea. Universidade de Évora (Portugal), 2001. 414p. Tese de doutorado.

SANTOS, Vitor Manuel V. Lopes dos. O sistema construtivo pombalino em Lisboa em edifícios urbanos agrupados de habitação colectiva: estudo de um legado humanista da segunda metade do século XVIII. Contributo para uma abordagem na área da recuperação e restauro arquitectónico do património construído. Lisboa, Fac. de Arquitectura da Universidade Técnica de Lisboa, 1994. Tese de doutorado.

SANVITALI, Federico (Pe.), Elementi di architettura civile, Brescia, Giammaria Rizzardi, 1745. Publicação póstuma.

SÃO BENTO, Bernardo de (Frei). «Declaraçoens de obras», [Rio de Janeiro], 1684. SILVA-NIGRA, Clemente da (D.). Fr. Bernardo de São Bento. Salvador: Tipografia Beneditina, 1950.

SARAIVA, José M. da Cunha. «A fortaleza de Bissau e a Companhia do Grão Pará e Maranhão», Atas do Congresso Comemorativo do $5^{\circ}$ Centenário do Descobrimento da Guiné. Lisboa, Soc. de Geografia de Lisboa, 1946, v. IX, p.157-191. 
SAVOT, Louis. L'architecture françoise des batiments particulieres. Paris, 1624.

SCAMOZZI, Vincenzo. L'idea della architettura universale (Veneza, V. Scamozzi, 1615), fac-símile, n. ${ }^{\circ}$ 9, sala Bolognese, Arnaldo Forni, 1982. Bibl. di Architettura Urbanistica, Teoria e Storia, coord. por Roberto Fregna e Giulio Nanetti.

SILVA-NIGRA, Clemente da (D.). «Francisco de Frias da Mesquita, engenheiro-mor do Brasil», Revista do SPHAN, n. 9, 1946.

SILVA-NIGRA, Clemente da (D.). Fr. Bernardo de São Bento. Salvador: Tipografia Beneditina, 1950.

SOUSA, Gabriel Soares de. Noticia do Brazil: descripçam verdadeira da costa daquelle estado que pertence a coroa do Reyno de Portugal, sitio da Bahia de Todos os Santos \& fertilidade daquella provincia, com rellação de todas as aves, animaes, peixes, bichos plantas, e costumes dos gentios muita serta, e curiosa (Mss., 1587), transcr. em português atual por Maria da Graça Pericão, Lisboa, Alfa, 1989.

THEOPHRASTUS. History of stones, trad. de Sir John Hill, Londres, s.n., 1774.

TOSCA, Tomaz Vicente. «Tractado de architectura civil», Compendio mathematico. Madrid: Antonio Marin, 1727, t. V, trat. XIV.

VARRON, Marco Terencio. De las cosas del campo (Rerum rustica). Trad. de Domingo Tirado Benedí, México: UNAM, 1945. Bibliotheca Scriptorum Græcorum et Romanorum Mexicana.

VASARI, Giorgio. Le vite de'piu eccelenti pittori, scultori, e architettori, $3^{a}$ ed. (revista e ampliada pelo próprio autor). Florença: Giunti, 1568.

VASCONCELLOS, Ignacio da Piedade (Pe.). Artefactos symmetriacos: e geometricos, advertidos, e descobertos pela industriosa perfeição das artes. Lisboa Occidental: Joseph Antonio da Sylva, 1733.

VITERBO, Francisco Marques de Sousa. Diccionário histórico e documental dos arquitectos, engenheiros e construtores portugueses. Lisboa: Imprensa Nacional/Casa da Moeda, 1988, 2 v.

VITRUVE. Les dix livres d'architecture, correção, tradução e notas de Claude Perrault (Paris, Jean Baptiste Coignard, 1684). Fac-símile, Bruxelas, Pierre Mardaga, 1979.

VITRUVIO POLIÓN. Los diez libros de arquitectura, trad. de Joseph Ortíz y Sanz (Madrid: Imprenta Real, 1787). Fac-símile com prólogo de Defín Rodríguez Ruiz, [Madrid], Akal, 1992. 
VITRUVIO POLIÓN. Marco Lucio. Los diez libros de arquitectura, introdução de Defín Rodríguez Ruiz, trad. de José Luis Oliver Domingo. Madrid: Alianza, 1995.

VITRUVIO POLLIO. De architettura, trad. e comentários de Daniel Barbaro. Veneza: Francesco Marcolini, 1556.

VITRÚVIO, Marco Lucio. Los diez libros de arquitectura, trad. de Agustín Blánquez. Barcelona: Iberia, 1955.

VITRÚVIO. Os dez livros de arquitectura, trad. de Helena Rua. Lisboa: IST, 1998.

VITRUVIUS. On architecture, trad. de Frank Granger, versão bilingüe latim/ inglês. Cambridge/Londres: Harvard University Press/William Heinemann, 1962. 2 V.

VITRUVIUS. The ten books on architecture, trad. de Morris Hicky Morgan. Nova lorque: Dover Publications, 1960 (reimpressão da edição publicada em Cambridge pela Harvard University Press, em 1914).

WINGATE. Michael, Small-scale lime-burning. Londres: ITP, 1985.

ZANINI, Gioseffe Viola. Della architettura, $2^{\mathrm{a}}$ impr.. Pádua: Giacomo Cadorino, 1677. 


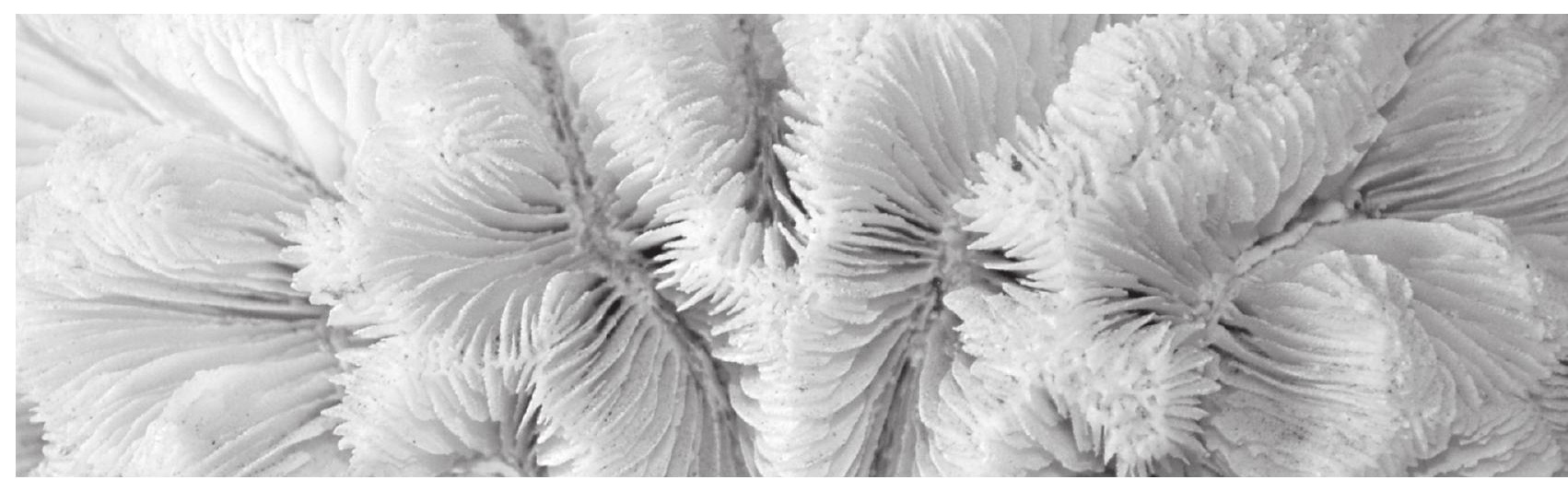

Anexos 


\section{Anexo 1}

\section{Ilustrações}

01. Uso de material espúrio na obturação de lacunas (Bahia, BR);

02. "Cabeça de carneiro" (coral do gênero Mussismilia)

03. Meandrina braziliensis

04. Rodolito

05. Cálice de coral encontrado em argamassa (Bahia)

06. Microfotografia de argamassa (Bahia)

07. Forno de cal (Jornada pelo Tejo)

08. (a) - Rabot (Jacques-François Blondel); (b) - Rabot (Lisboa, PT)

09. Extinção de cal (Inglaterra)

10. Ensaio de espectroscopia de emissão atômica por plasma

11. Cascas de lambretas

12. Cascas de ostras e de lambretas

13. Pozolana

14. Máquina de fazer ciment (Belidor)

\section{Créditos}

- Ilustrações 2 a 6, 8 (b), 9 a 12 - Acervo pessoal da autora;

- Ilustração 8(a) - BLONDEL, J.-F., Cours d'architecture;

- llustrações 1 - Acervo do NTPR;

- Ilustração 7 - NEGREIROS, José Manuel de Carvalho, Jornada pelo Tejo (AHM, cód. 80);

- llustração 13 - Prof. Lorenzo Lazzarini;

- Ilustração 14 - BELIDOR, Bernard Forest de, Architecture hydraulique. 


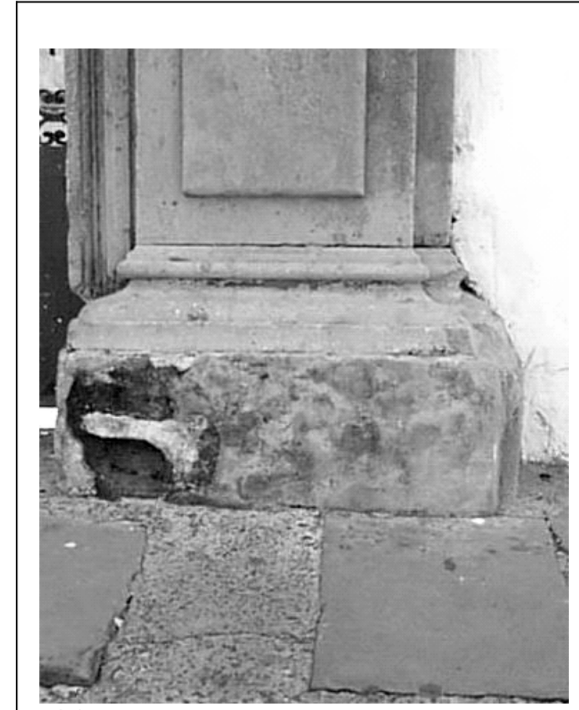

(a)

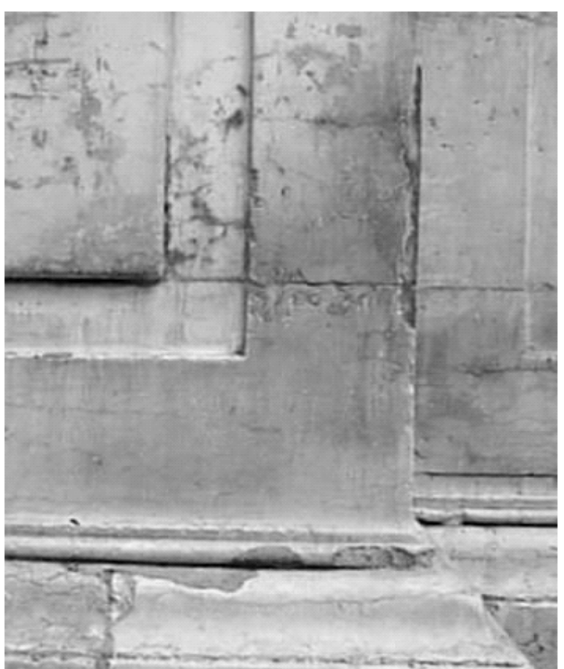

(b)

II. 1 - Salvador: (a) reintegrações inadequadas com uso de argamassa de cimento tipo Portland, na base do portal da Igreja da Venerável Ordem $3^{a}$ de S. Francisco (Séc. XVIII). (b) idem, na fachada da lgreja do Colégio de Jesus (séc. XVII), atual Catedral Basílica.

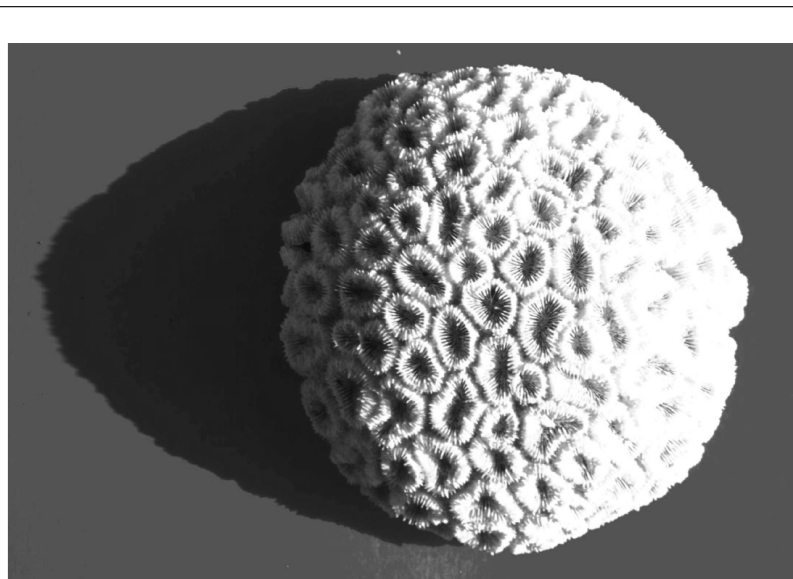

II. 2 - Coral "Cabeça de carneiro", do gênero Mussismilia, usado na fabricação da cal.

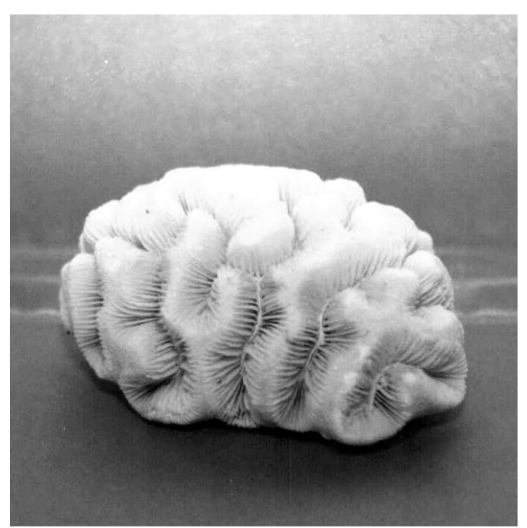

II. 3 - Coral Meandrina braziliensis, usado na fabricação da cal. 

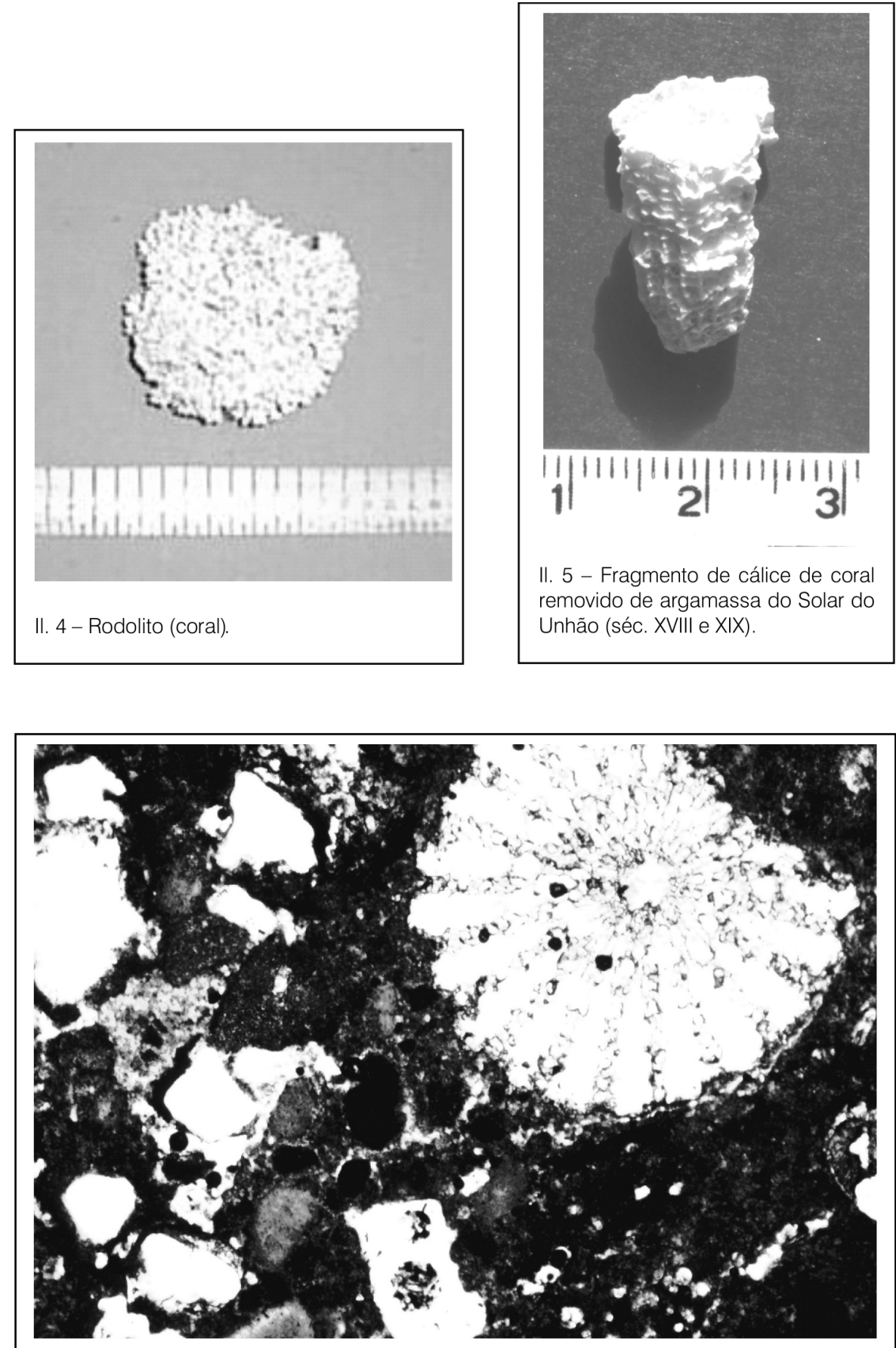

II. 6 - Salvador: microfotografia de argamassa antiga da Igreja do Colégio Jesuíta, hoje Catedral, onde se observam fragmentos de seres marinhos. 

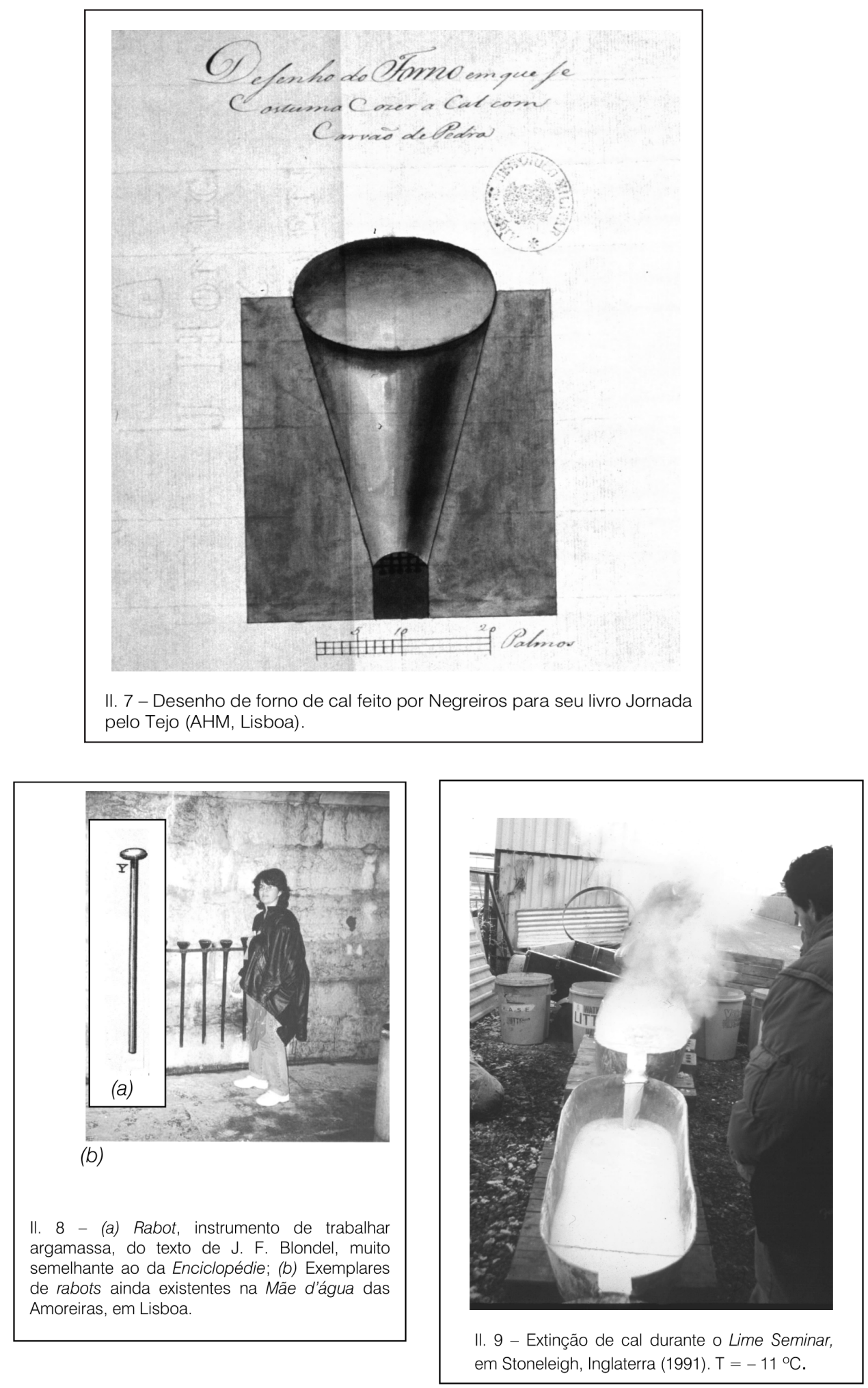


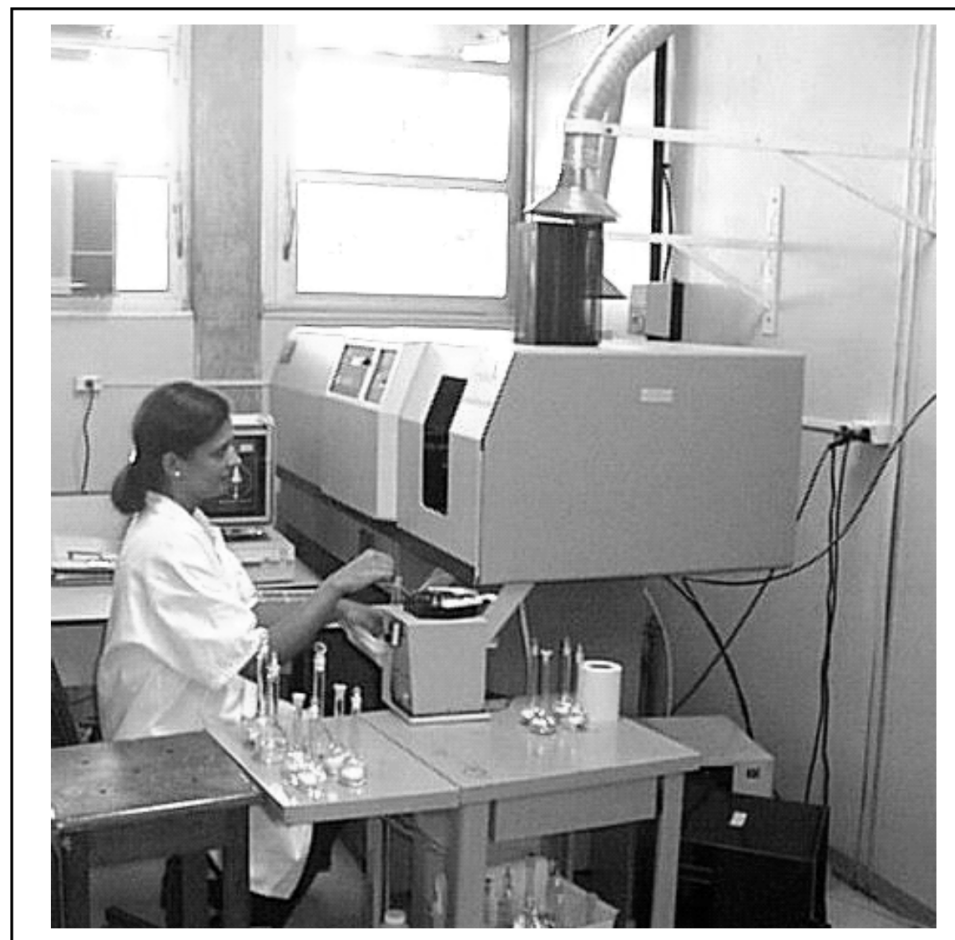

II. 10 - Dosagem das cais, por espectroscopia de emissão atômica por plasma, feita no Instituto de Química da UFBA.

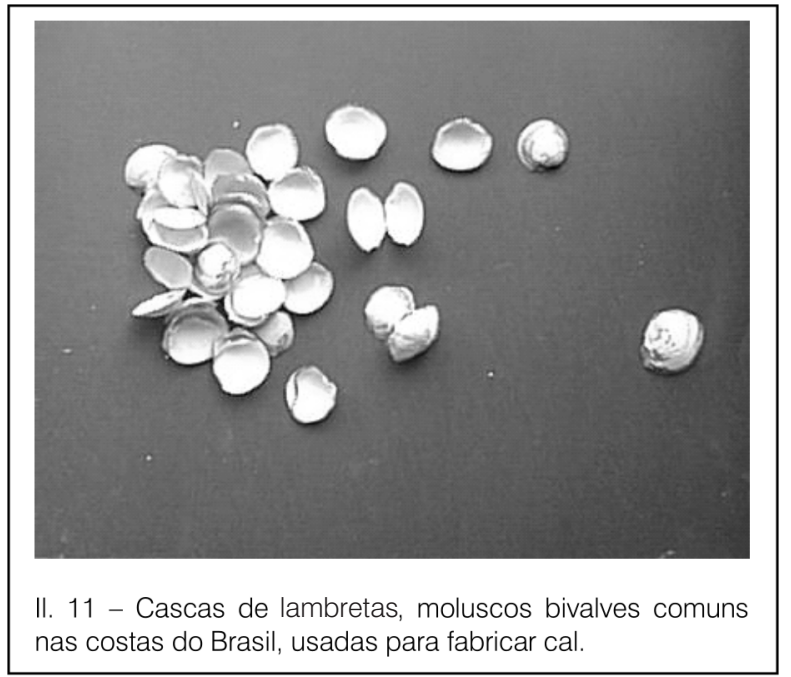




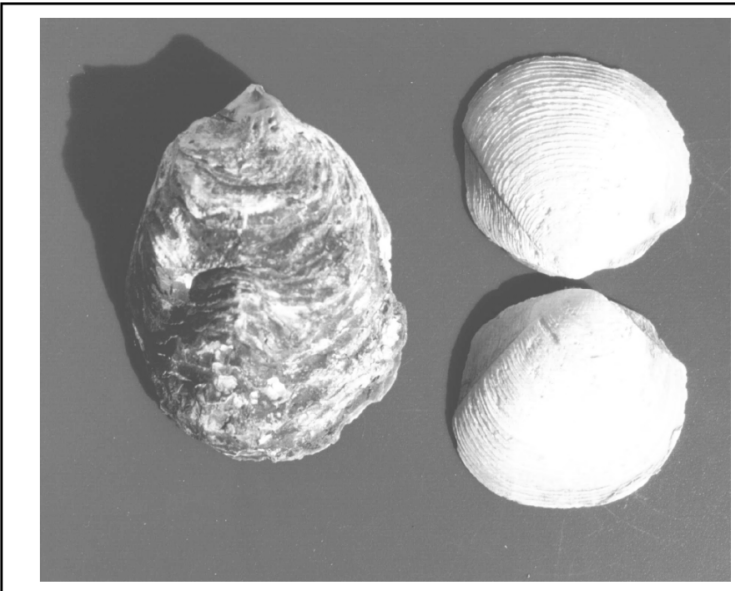

II. 12 - Ostra e lambreta (bivalves), recolhidas na Baía de Todos os Santos, também usadas para fabricação da cal.

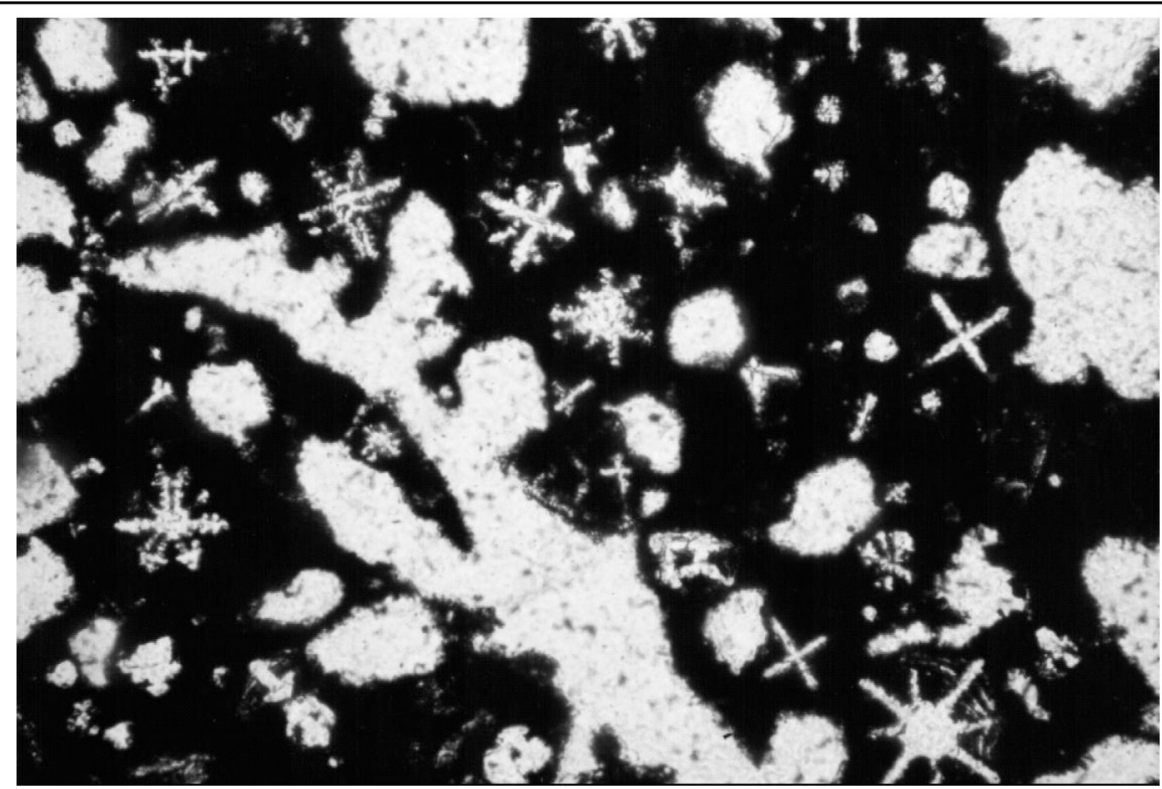

II. 13 - Microfotografia de uma partícula de pozolana mostrando a elevada porosidade e as típicas figuras de quenching no vidro vulcânico (marrom-avermelhado). 


\section{MACHINE pour piler du Ciment}

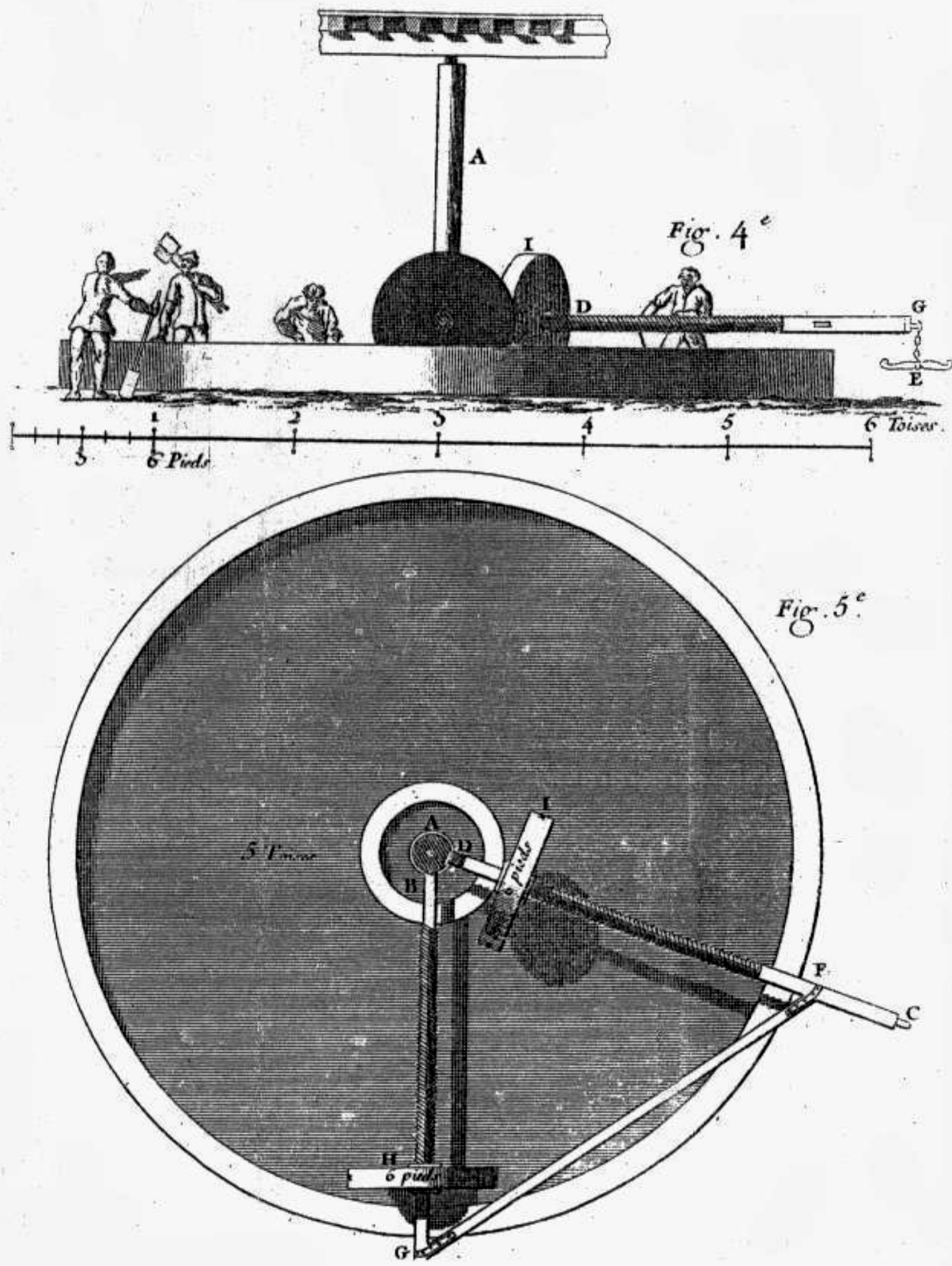

II. 14 - llustração do livro Architecture Hydraulique, de Belidor, mostrando uma máquina de fabricar ciment (séc. XVIII). Observa-se que as mós se deslocam ao longo dos dois eixos para atingir toda a mistura no recipiente. 
Transcrição da tabela dos ensaios realizados pelo engenheiro Ernesto Cunha (séc. XIX) com argamassas e cais de marisco (Brasil)

"Experiências de resistencia á compressão da cal e de argamassas pelo Engenheiro Ernesto Marcos Tygna da Cunha, apresentadas ao Club de Engenharia em 4 de Julho de 1883.

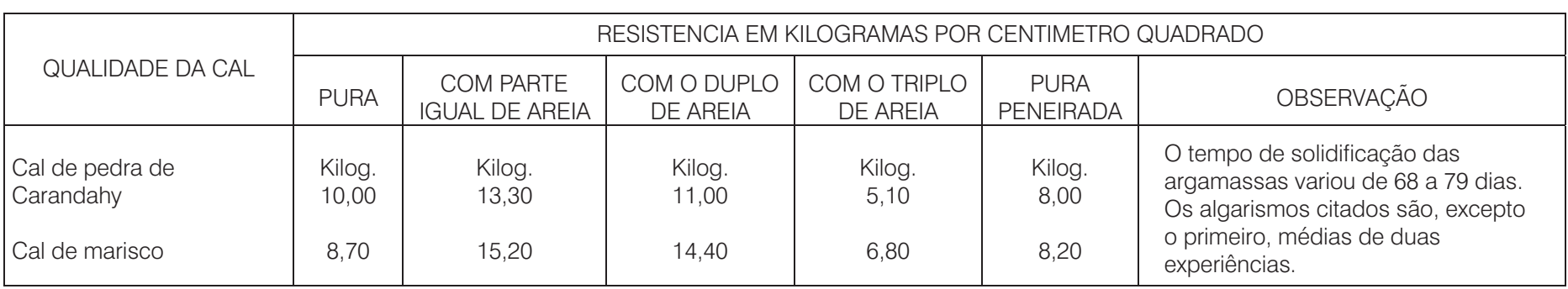

As experiencias foram feitas com prismas rectos de secção quadrada com cinco centimetros de comprimento e $3 \mathrm{c} / \mathrm{m}, 5 \times 3 \mathrm{c} / \mathrm{m}, 5$ de base.

Cumpre registrar que a cal pura e peneirada diminue a resistencia á compressão, e que o maximo de resistencia pertence as argamassas de partes iguaes ou de um de cal para dous de areia, medidas em volume a secco".

Fonte: REBOUÇAS, André. Guia para os alumnos da $1^{\text {a }}$ cadeira do $1^{0}$ anno de engenharia civil, Rio de Janeiro, Typographia Nacional, 1885. p. 72 


\section{Anexo 3}

\section{Caracterização de algumas matérias-primas usadas tradicionalmente na fabricação de cais}

\begin{tabular}{|c|c|c|c|c|c|c|c|}
\hline & & \multicolumn{5}{|c|}{ Brasil } & \multirow{3}{*}{$\begin{array}{l}\text { Portugal } \\
\text { Pedra lioz }\end{array}$} \\
\hline & & \multicolumn{2}{|c|}{ Conchas } & \multicolumn{2}{|c|}{ Corais } & \multirow{2}{*}{ Mármore branco } & \\
\hline & & Ostra & Lambreta & Meandrina & Mussismilia & & \\
\hline \multirow{7}{*}{$\begin{array}{l}\text { Composição } \\
\text { química } \\
(\%)\end{array}$} & $\mathrm{SiO}_{2}$ & 0,33 & 1,09 & 0,06 & 0,04 & 0,16 & 0,81 \\
\hline & $\mathrm{Fe}_{2} \mathrm{O}_{3}$ & 0,05 & 0,10 & 0,03 & 0,05 & 0,06 & 0,11 \\
\hline & $\mathrm{Al}_{2} \mathrm{O}_{3}$ & 0,26 & 0,10 & 0,07 & 0,26 & 0,07 & 0,10 \\
\hline & $\mathrm{CaO}$ & 50,49 & 50,36 & 49,19 & 48,85 & 31,94 & 50,71 \\
\hline & $\mathrm{MgO}$ & 0,45 & 0,21 & 0,10 & 0,23 & 17,43 & 0,32 \\
\hline & $\mathrm{BaO}$ & 0,0002 & 0,0008 & 0,003 & 0,001 & 0,0003 & 0,001 \\
\hline & $\mathrm{SrO}$ & 0,12 & 0,18 & 0,86 & 0,85 & 0,01 & 0,05 \\
\hline \multicolumn{2}{|c|}{$\mathrm{i}=\frac{\left(\% \mathrm{SiO}_{2}+\% \mathrm{Fe}_{2} \mathrm{O}_{3}+\% \mathrm{Al}_{2} \underline{\mathrm{O}}_{3}\right)}{\% \mathrm{CaO}+\% \mathrm{MgO}}$} & 0,01 & 0,02 & 0,01 & 0,01 & 0,01 & 0,02 \\
\hline
\end{tabular}


Caracterização de cais preparadas em laboratório com matérias-primas tradicionalmente usadas na construção civil no Brasil, até o século XIX

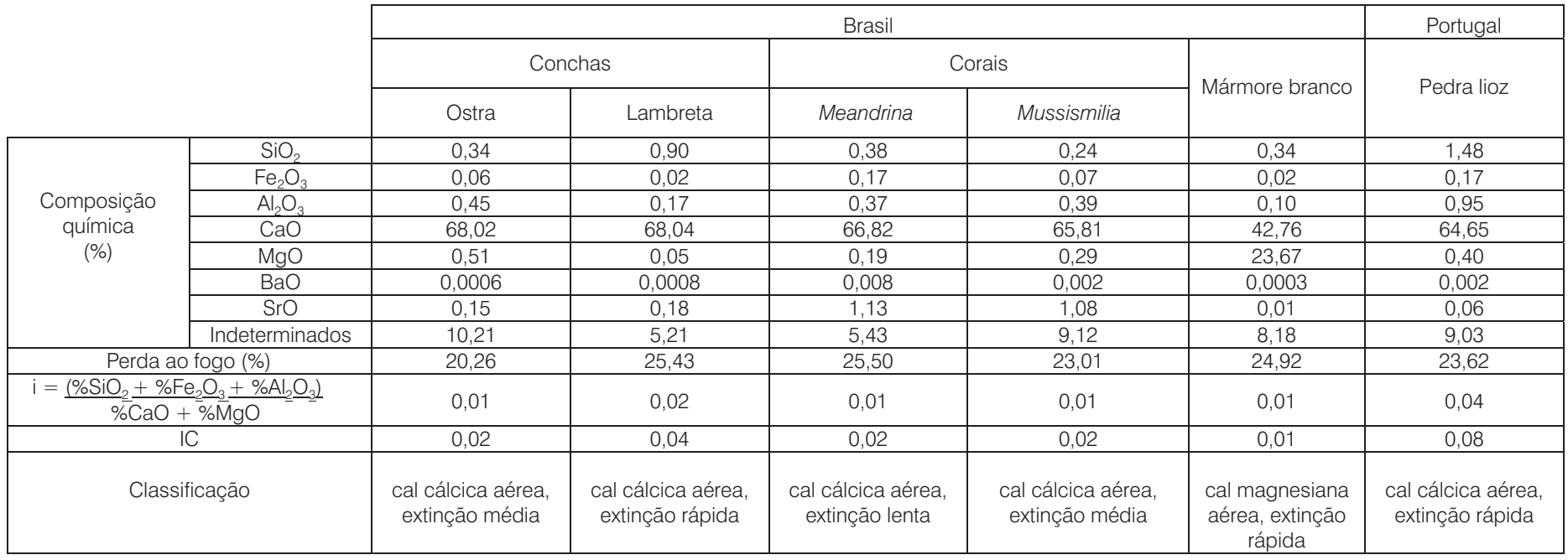

Classificação das cais:

\begin{tabular}{|c|c|c|c|}
\hline $\begin{array}{l}\text { Quanto à composição química': } \\
\text { Cal cálcica: } \quad \% \mathrm{MgO}<20 \% \\
\text { Cal magnesiana: }\end{array}$ & $\begin{array}{l}\text { Quanto ao índice de hidrauli } \\
\text { Cal aérea: i }<0,1 \\
\text { Cal hidráulica: } \\
\text { Fracamente hidráulica } \\
\text { Medianamente hidráulica } \\
\text { Francamente hidráulica } \\
\text { Eminentemente hidráulica }\end{array}$ & $\begin{array}{l}\text { licidade }^{2} \text { : } \\
0,10<i<0,16 \\
0,16<i<0,30 \\
0,30<i<0,40 \\
0,40<i<0,50\end{array}$ & 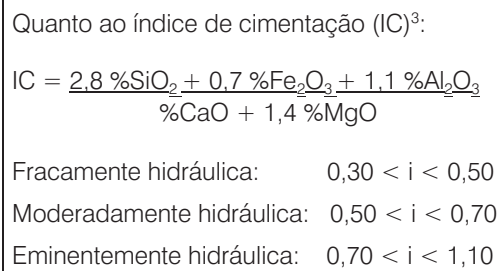 \\
\hline
\end{tabular}

1 PETRUCCI, Eládio G. Materiais de construção, 8. ed., RJ, Globo, 1987. Cap. VI, p. 323.

2 PETRUCCI, Eládio G. Materiais de construção, 8. ed., RJ, Globo, 1987. Cap. VI, p. 327.

${ }^{3}$ GUIMARÃes, José Epitácio Passos. A cal. São Paulo: Pini, 1997, p. 91 e 266. 


\begin{tabular}{|c|c|}
\hline & COLOFÃO \\
\hline Formato & $17 \times 24 \mathrm{~cm}$ \\
\hline Tipologia & $\begin{array}{l}\text { Swis721 Lt BT 10,5/15 (texto) } \\
\text { Swis721 BlkEx BT e Hv BT (títulos) }\end{array}$ \\
\hline Papel & $\begin{array}{l}\text { Alcalino } 75 \mathrm{~g} / \mathrm{m}^{2} \text { (miolo) } \\
\text { Cartão Supremo } 250 \mathrm{~g} / \mathrm{m}^{2} \text { (capa) }\end{array}$ \\
\hline Impressão & Setor de Reprografia da EDUFBA \\
\hline Capa e Acabamento & Bigraf \\
\hline Tiragem & 500 \\
\hline
\end{tabular}

